\title{
NEIGHBORHOODS, PROXIMITY TO DAILY NEEDS, \& WALKABILITY IN FORM-BASED CODES
}

\author{
A Thesis \\ presented to \\ the Faculty of California Polytechnic State University, \\ San Luis Obispo
}

\author{
In Partial Fulfillment \\ of the Requirements for the Degree \\ Master of City and Regional Planning
}

by

Evan Evangelopoulos

December 2014 
(C) 2014

Evan Evangelopoulos ALL RIGHTS RESERVED 
COMMITTEE MEMBERSHIP

TITLE: $\quad$ Neighborhoods, Proximity to Daily Needs, \& Walkability in Form-Based Codes

AUTHOR: $\quad$ Evan Evangelopoulos

DATE SUBMITTED: $\quad$ December 2014

COMMITTEE CHAIR: Cornelius Nuworsoo, PhD

Professor of City and Regional Planning

COMMITTEE MEMBER: Chris William Clark, JD

Lecturer of City and Regional Planning

COMMITTEE MEMBER: Vicente del Rio, PhD

Professor of City and Regional Planning 


\author{
ABSTRACT \\ Neighborhoods, Proximity to Daily Needs, \& Walkability in Form-Based \\ Codes Evan Evangelopoulos
}

Form-based codes are evaluated with criteria often requiring additional clarification. To better identify form-based code evaluation criteria, this thesis identifies the major intentions of form-based codes from the literature and focuses on the first intention, quality of life. The form-based code literature relates quality of life to three principles with underlying parameters: neighborhood with a center and edge, proximity to daily needs, and walkability. Neighborhood refers to the identification of walkable districts of about .25 mile radius with a clear center and edge. Proximity to daily needs requires diversity of uses in proximity to residential uses so that residents travel short distances to address daily needs. Walkability is a more complex principle with numerous impacting parameters effective only when working in tandem with each other. A selection of six case studies from award-wining form-based codes test the presence of the three quality of life principles in form-based code practice and the findings are discussed. All six case studies incorporated the three quality of life principles with some differences in all form-based planning process phases. Neighborhood is used as equivalent to a .25 mile pedestrian shed. The value of the concept of neighborhood edge in from-based codes remains unclear, however, since few case studies included it and needs to be explored further. Neighborhood with a center and edge therefore can be rephrased to a .25 mile pedestrian shed with a center. The .25 mile pedestrian shed alone is a fundamental parameter in all 3 quality of life principles and all case studies incorporated this parameter. Proximity to daily needs parameters as identified are also incorporated in all case studies. Walkability parameters that require building adaptations to walkable environments were present in all case studies. Walkability parameters, however, addressing standards for sidewalks and streets, were uncommon in some studies and, as a result, application of walkability parameters varied across case studies. The three principles of pedestrian shed with a center, proximity to daily needs, and walkability can be used as part of the set of criteria to assess form-based codes. All three principles point to the direction of sustainability in an effort to create cities that are efficient to manage and highly appropriate for daily human function.

Keywords: Form-based codes, use-based codes, neighborhood, neighborhood center, walkability, pedestrian shed, regulating plan, proximity to daily needs, complete neighborhoods, 20 minute neighborhoods. 


\section{ACKNOWLEDGMENTS}

To my gracious grandfather, the man who helped me throughout life with his presence, positive attitude, admiration, strength, courage, love of books and science, and stories of success and wit.

Thanks also to Alan Marmoset at the Form-Based Code Institute for his always encouraging and engaging discussions and the opportunity he opened for me.

And to all friends positively present and patiently supportive of this task including David, Theia Nitsa, Alex, Melinda, Christina, Clayton, John, Brook and others. Also to my dear uncle and aunt Erotokritos and Kassiane. 
Page

LIST OF TABLES

LIST OF FIGURES

1. INTRODUCTION

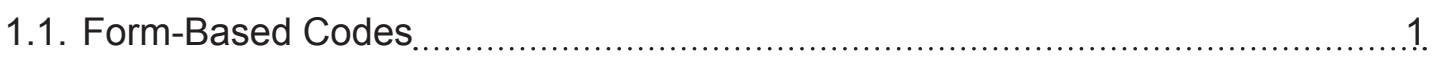

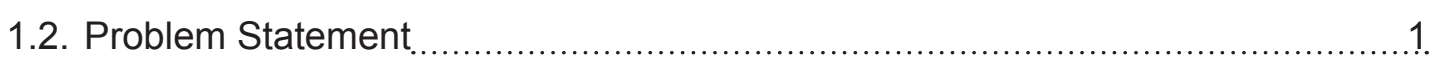

1.3. Hypothesis and Relevance

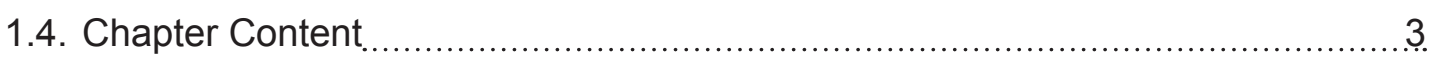

2. ZONING

2.1. Impact of Zoning on the Land

2.2. History of Urban Regulations

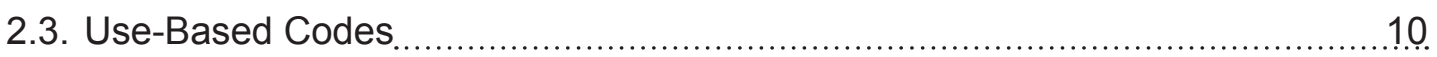

2.3.1.Used-Based Zoning Legislative Authorization .................................... 10

Use-based Zoning Beginnings .......................................................

Supreme Court and Federal Government Endorsement......................11.

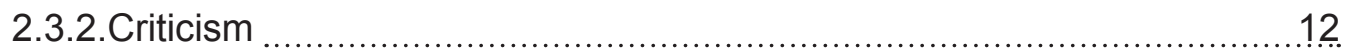

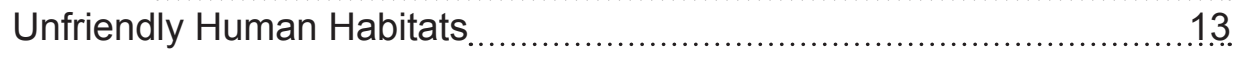

Inefficient and Unsustainable Cities ………………………....................... 14

2.3.3.Suggested Solutions and Form-Based Zoning .......................................16

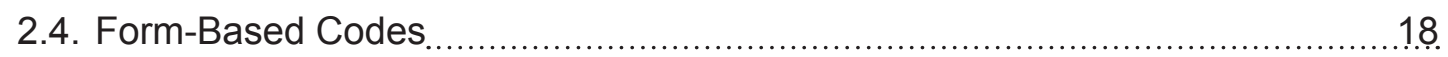

2.4.1.Neighborhoods and Zones of Urban Intensity ................................... 18

2.4.2.Regulating Plans vs Land-Use Maps …………….............................. 20

2.4.3.Form-Based Codes and the SmartCode ............................................ 21

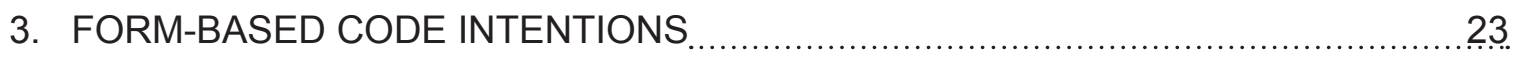

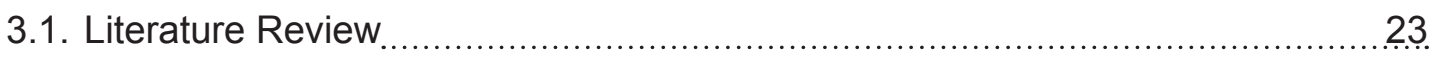

3.1.1.Form-Based Codes Institute (2014c) …………….............................24

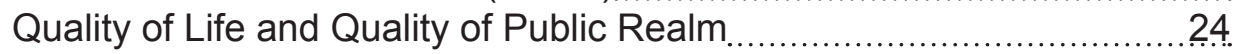

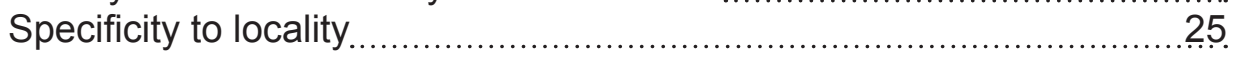

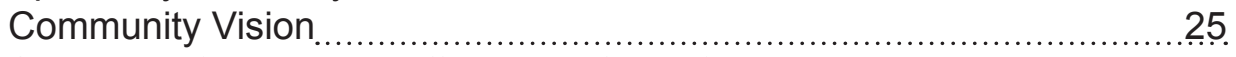

Structure, Clarity, and Efficiency of the Code and Development

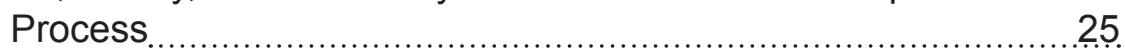

3.1.2.The Chicago Metropolitan Agency for Planning (2014) ….................... 26

Quality of Life and Quality of Public Realm

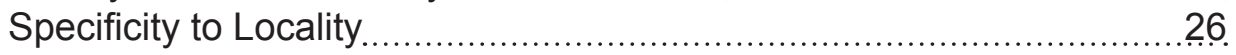

Community Vision .................................................................................

Structure, Clarity, and Efficiency of the Code and Development Process

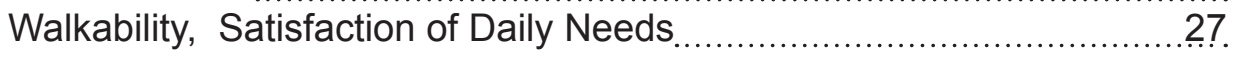




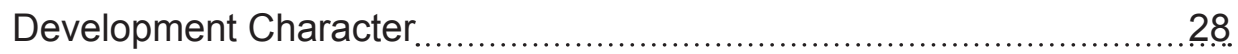

3.1.3.Duany, A., Sorlein, S., \& Wright, W. (2008) (The SmartCode)...................

Quality of Life and Quality of Public Realm ....................................... 28.

Code Structure, Clarity, Efficiency and Development Process ............. 28.

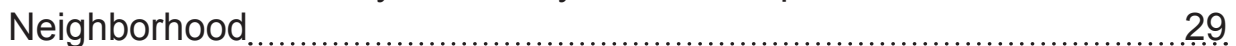

Walkability, Satisfaction of Daily Needs ........................................ 29

Community Strengthening. ........................................................ 30

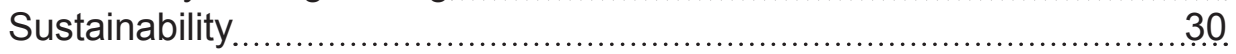

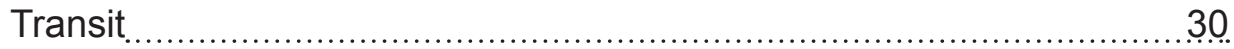

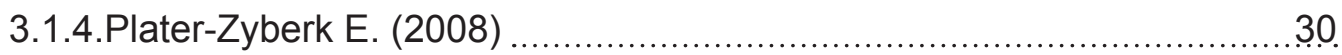

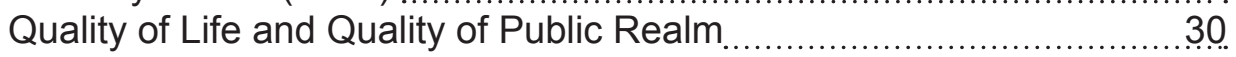

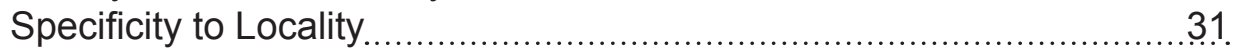

Community........................................................................ 31

Code Structure, Clarity, and Administrative Process ......................... 31

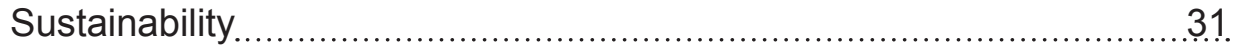

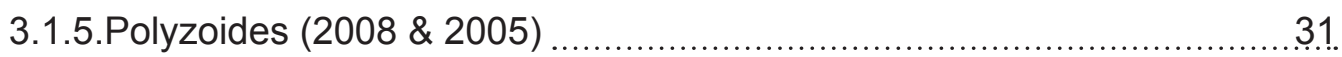

Quality of Life and Quality of Public Realm ....................................... 32

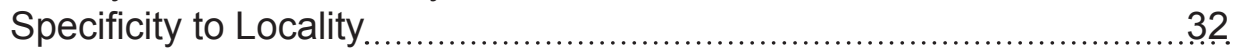

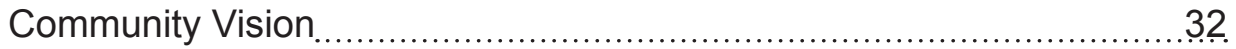

Code Structure, Clarity, and Administrative Process ............................. 32

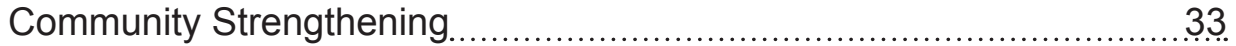

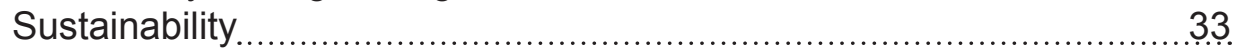

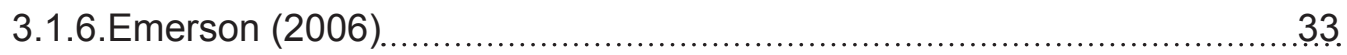

Quality of Life and Quality of Public Realm ................................... 34

Specificity to Locality.................................................................. 34

Code Structure, Clarity, and Administrative Process ......................... 34

Improvement over Euclidean Codes ............................................. 34

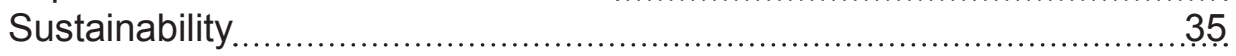

3.1.7. Parolek, Parolek \& Crawford (2008)................................................. 35

Quality of Life and Quality of Public Realm .......................................

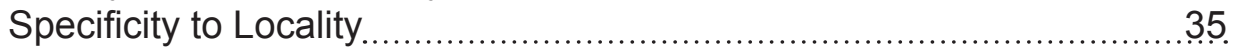

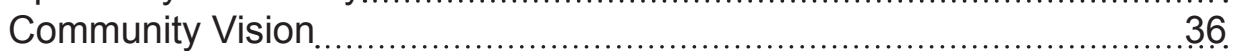

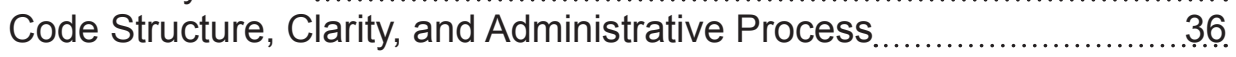

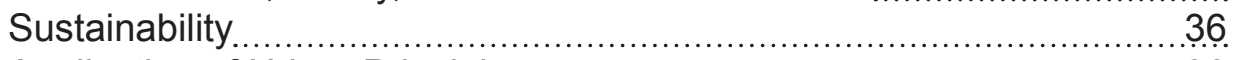

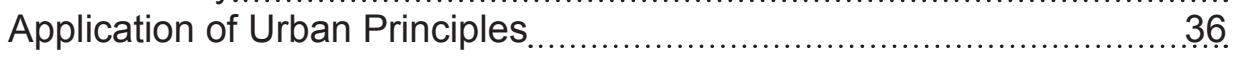

3.2. Form-Based Code Intentions Conclusions \& Summary .................................. 37.

4. QUALITY OF LIFE INTENTIONS IN FORM-BASED CODES .............................. 42

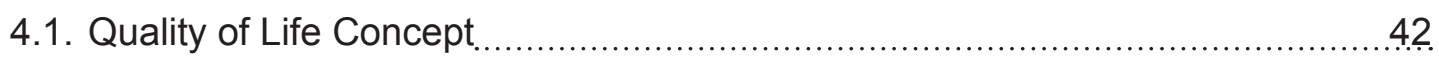

4.1.1.Environment-Shapes-Behavior Theories .......................................... 42

4.1.2.Urban Environment and Quality of Life Principles ............................... 42

Definition of Urban Design Principles .......................................... 42

Urban Design and Urban Morphology ........................................... 43

Community Vision and Urban Design Principles ................................. 43.

Quality of Life and Urban Design Principles ......................................... 44 
4.2. Quality of Life Principles in Form-Based Code Theory .................................. 48

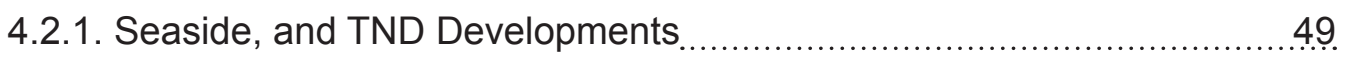

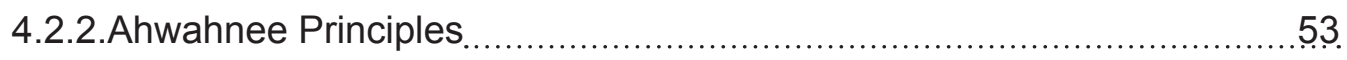

4.2.3. Congress for New Urbanism Principles............................................. 54.

4.2.4.Smart Growth Principles ....................................................... 55

4.2.5.Summary of Form-based Code Principles Contributing to Quality

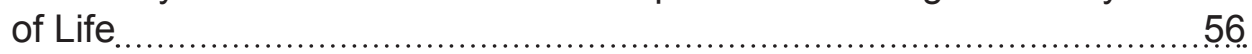

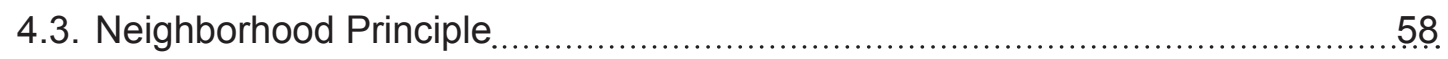

4.3.1. Neighborhood definition and history ............................................ 58

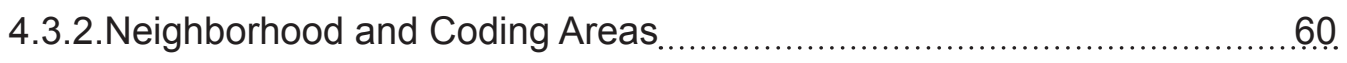

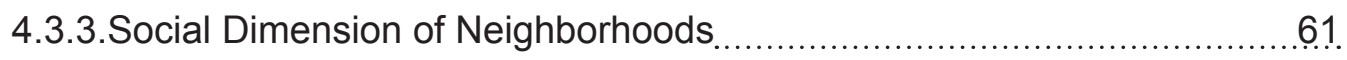

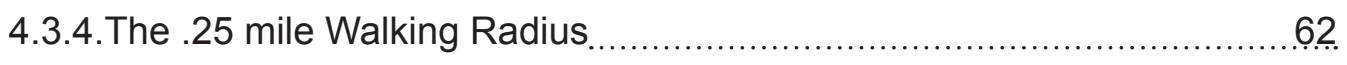

4.3.5.Neighborhood Parameters In Form-Based Codes .............................. 65

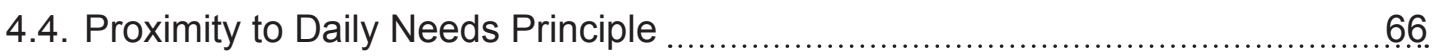

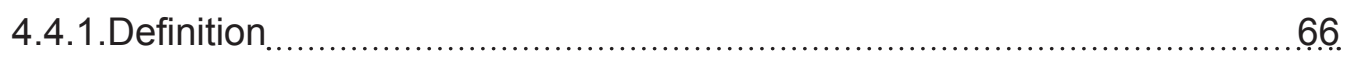

4.4.2.Proximity to Daily Needs Parameters ..................................................6. 69

4.4.3. Complete Neighborhoods..........................................................

4.4.4. Neighborhood Sustainability and Self-sufficiency............................... 71.

4.4.5.Proximity to Daily Needs Parameters in Form-Based Codes ................ 72

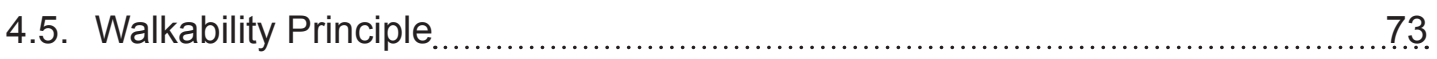

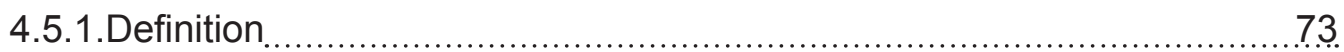

4.5.2.Walkability Parameters ............................................................ 74

4.5.3.Walkability Parameters Application in Form-Based Codes .................... 83

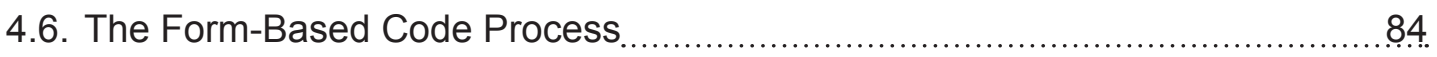

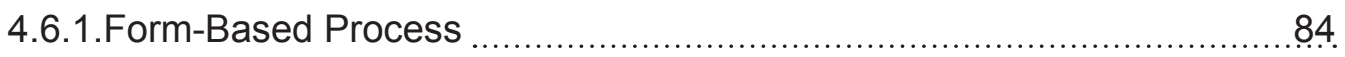

4.6.2.The Illustrative and Master Plans _..................................................... 84

4.6.3.The Regulating Plan ........................................................................ 85

4.6.4.The Form-Based Zoning Code .......................................................... 86

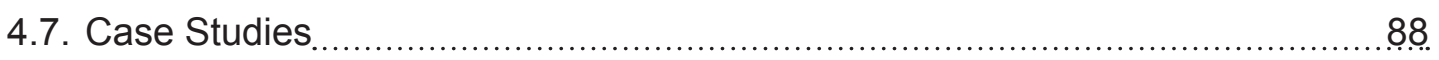

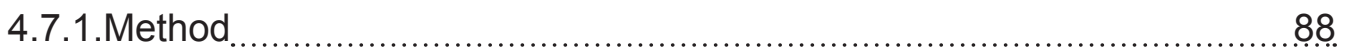

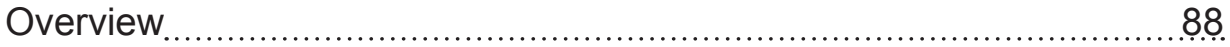

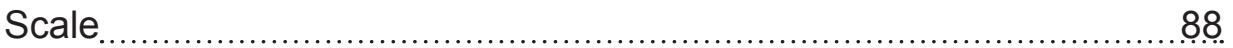

Principle and Parameter Evaluation ............................................ 89

Neighborhood principle parameters ....................................... 90

Proximity to Daily needs principle parameters ........................... 90.90

Walkability principle parameters within the 5Ds .............................

4.7.2. Farmers Branch Station Area, TX (2007 Driehaus Award) ..................... 95

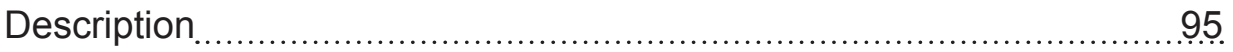

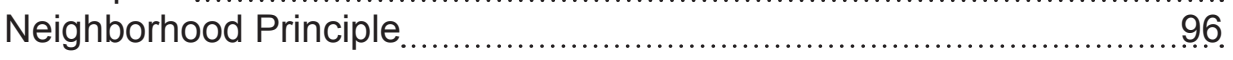

Proximity to Daily Needs Principle. .............................................. 97. 
Walkability Principle.

4.7.3.Benicia, CA Downtown Mixed Use Master Plan (2008 Driehaus

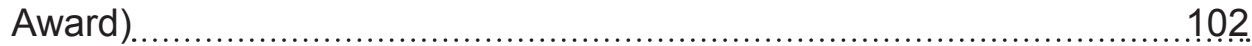

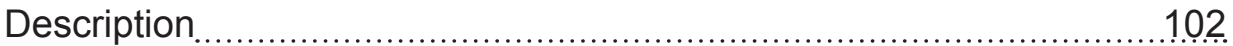

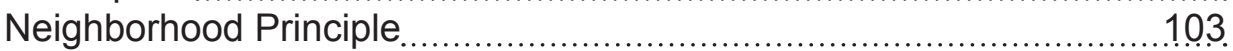

Proximity to Daily Needs Principle .............................................. 104

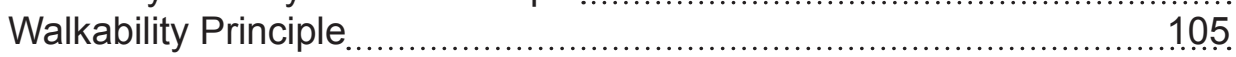

4.7.4.St. Lucie County, FL (Driehaus Award, 2007)................................... 109

Project Description ............................................................... 109

Neighborhood Principle ............................................................... 110

Proximity to Daily Needs Principle

Walkability Principle ................................................................... 113

4.7.5.Lee County, FL Compact Communities Code (2011)..........................117.

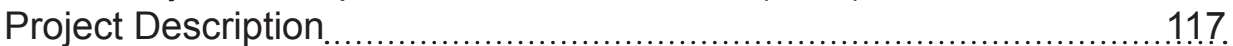

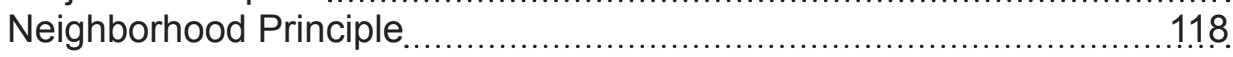

Proximity to Daily Needs Principle ................................................121.

Walkability Principle ................................................................. 122

4.7.6. The Cincinnati Form-Based Code (2014 Driehaus Honorable Men-

tion)

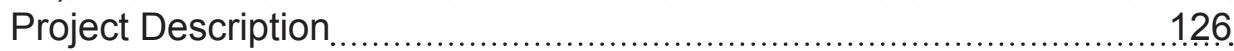

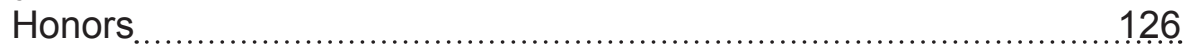

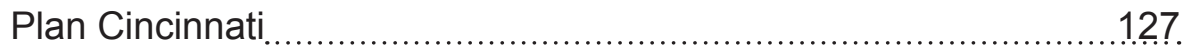

The Form-Based Code ......................................................... 127

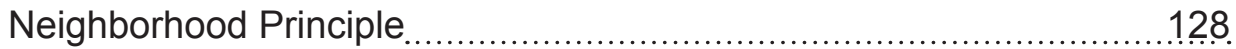

Proximity to Daily Needs Principle ................................................129.

Walkability Principle ............................................................... 130

4.7.7. Heart of Peoria Form-Based Code (2010 Driehaus Award).................135

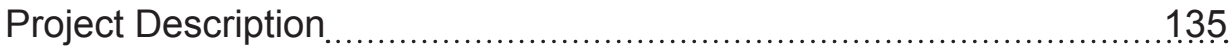

Heart of Peoria Plan ........................................................135

Land Development Code for the Heart of Peoria .........................136

Neighborhood Principle .......................................................... 137

Proximity to Daily Needs Principle ..............................................141.

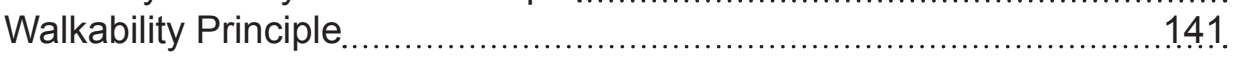

4.7.8. Case Study Findings ................................................................ 148

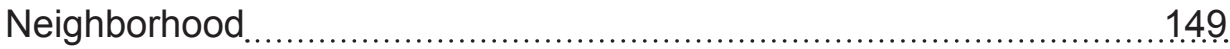

Proximity To Daily Needs.......................................................... 151.

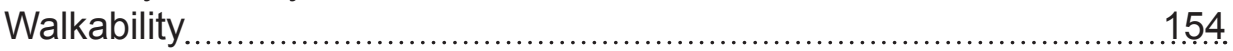

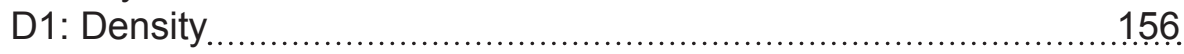

D2: Diversity ..................................................................... 156

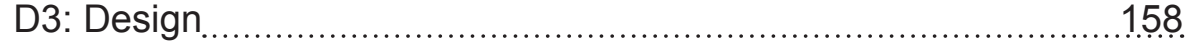

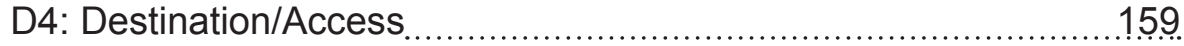

D5: Distance ....................................................................

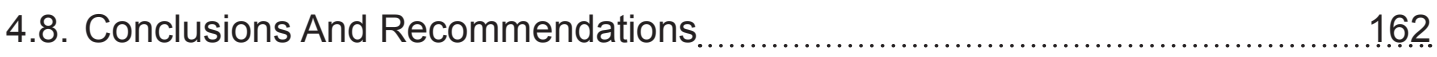

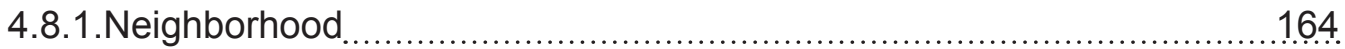

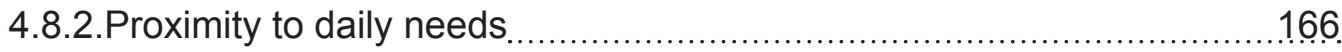

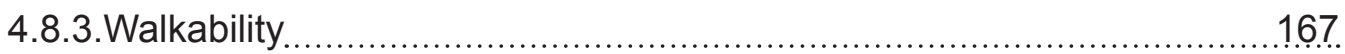




\section{APPENDICES}

Appendix I: Ahwahnee Principles. 177

Ahwahnee Community Principles..............................................177.

Ahwahnee Regional Principles .............................................................

Appendix II: Smart Growth Principles ..................................................... 180

Appendix III: Charter for New Urbanism Select Principles ...............................182.

Appendix IV: Charter for New Urbanism Principles (Full Set) ................................

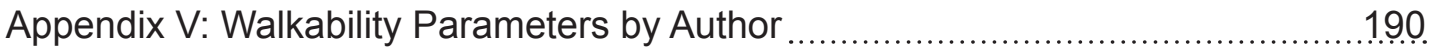

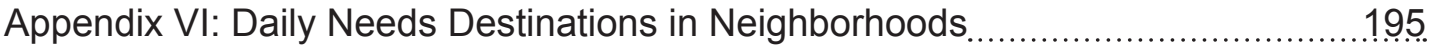

Appendix VII: Regulations and Coding Standards per Case Study .......................197. 
Page

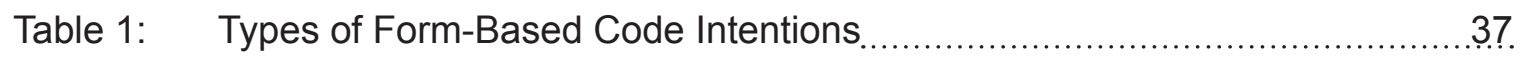

Table 2: $\quad$ Walkability Parameters in the Built Environment under the 5Ds ...................

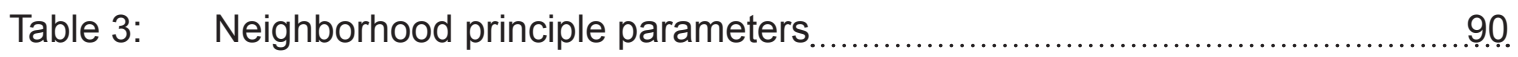

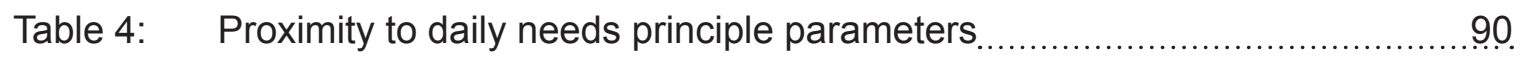

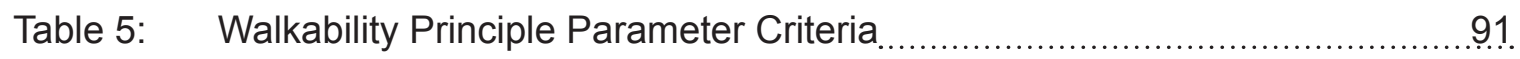

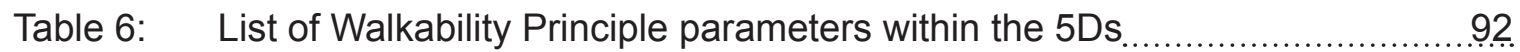

Table 7: $\quad$ Neighborhood Principle: Farmers Branch Station Area, TX ........................ 97.

Table 8: $\quad$ Proximity to Daily Needs Principle: Farmers Branch Station Area, TX ......... 97.

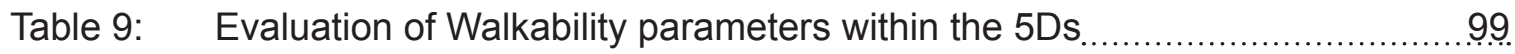

Table 10: Neighborhood Principle: Benicia, CA Downtown Mixed Use Master Plan ..103

Table 11: Proximity to Daily Needs Principle: Benicia, CA Downtown Mixed Use Master Plan ........................................................................ 105

Table 12: Evaluation of Walkability parameters within the 5Ds: Benicia, CA Downtown Mixed Use Master Plan.

Table 13: Neighborhood Principle: St. Lucie County, FL ,Towns, Villages and Countryside (TVC) Overlay Form-Based Code.

Table 14: Proximity to Daily Needs Principle: St. Lucie County, Florida Towns, Villages and Countryside (TVC) Overlay Form-Based Code.

Table 15: Evaluation of Walkability parameters within the 5Ds: St. Lucie County, Florida Towns, Villages and Countryside (TVC) Overlay Form-Based Code.

Table 16: Neighborhood Principle: Lee County, FL Compact Communities Code ......120.

Table 17: Proximity to Daily Needs Principle: Lee County, FL Compact Communities Code.

Table 18: Evaluation of Walkability parameters within the 5Ds: Lee County, FL Compact Communities Code......

Table 19: Neighborhood Principle: The Cincinnati Form-Based Code......

Table 20: Proximity to Daily Needs Principle: The Cincinnati Form-Based Code .......129. 
Table 21: Evaluation of Walkability parameters within the 5Ds: The Cincinnati Form-Based Code.

Table 22: Neighborhood Principle: Heart of Peoria Form-Based Code.....

Table 23: Proximity to Daily Needs Principle: Heart of Peoria Form-Based Code.

Table 24: Evaluation of Walkability parameters within the 5Ds: Heart of Peoria Form-Based Code.

Table 25: Case Study Quality of Life Principles Cumulative Table 148

Table 26: Neighborhood Principle Parameter Cumulative Table

Table 27: Proximity to Daily Needs Principle Cumulative Table

Table 28: Walkability Principle Cumulative Table. 154

Table 29: Built-Environment Parameters Impacting Walkability by Author 190 


\section{LIST OF FIGURES}

Page

Figure 1: Diagrammatic depiction of the triad of controls that shape land and building development according to Platter-Zyberk E. (2008).

Figure 2: Diagrammatic depiction of the three impacts of zoning on land according to Talen (2012).

Figure 3: The first zoning code in Frankfurt, Germany in 1891. From City Rules, How Regulations Affect City Form, by Talen E., 2012, p. 30.

Figure 4: Cross-sectional organization of transects showing how transects standardize urban intensity gradation from dense urban core to rural and natural. According to form-based codes, every transect creates a separate coding zone. Adapted from Urban Design/Planing - Form-Based Codes by Glaserworks, 2014.

Figure 5: Typical urban area cross-sectional organization and gradation of transects within neighborhoods (red circles). Neighborhood radii are usually that of the 5 minute walk (.25 miles) but it can vary up to a mile sometimes. Note that in the neighborhood on the right the center is to the left. Location of centers can vary depending on the conditions. Adapted from Urban Design/Planing - Form-Based Codes by Glaserworks, 2014.

Figure 6: Plan-View organization of transects. City of Hayward, CA form-based code regulating plan showing 5 and 10 minute walk delineations with marked centers as higher density transects. From City of Hayward, CA (2011, Para. 3, Figure 1-1: Regulating Plan Map).

Figure 7: Schematic of a Neighborhood with an outlined center, edge, and assigned urban intensity areas (transects T3 to T5). Adapted from FormBased Codes by Parolek, Parolek \& Crawford, 2008, p. 161.

Figure 8: One of six sectors of Ebenezer Howard's Garden City in Howard \& Osborn (1965), with colors, train tracks and lot divisions in bottom right block added in the original black and white image for clarity. Adapted from Howard \& Osborn, 1965, pp. 22-23.

Figure 9: Clarence Perry's Neighborhood concept. Adapted from Mehaffy, Porta \& Romice, 2014, p. 2.

Figure 10: The first form-based Code in Seaside, FL. From The Seaside Code by Salden, $2014 a$.

Figure 11: A set of buildings (transect) assigned separate standards around the central plaza in Seaside, FL. From The Seaside Code by Salden, 2014a... 51.

Figure 12: Aerial photo of Seaside, FL (Google Earth Image). 
Figure 13: Applying the neighborhood principle to understand urban structure in Brisbane, Australia. Adapted from Optimizing Urban Structure: Towards an Integrated New Urbanist Model by Jones, 2009, p. 9.

Figure 14: Cells or else urban units making up a city according to Kevin Lynch's cellular model. From City Form by Lynch, 1984, p. 400.

Figure 15: Urban model of best fitting pedestrian sheds and commercial nuclei. Adapted from "Urban nuclei and the geometry of streets: The 'emergent neighborhoods' model" by Mehaffy, Porta, Rofè \& Salingaros, 2010, Urban Design International, 15(1), p. 31.

Figure 16: Urban plan of Tel Aviv, Israel by Scottish architect Patrick Geddes that according to Mehaffy, Porta, Rofè \& Salingaros (2010) exemplifies the proposed model of urban nuclei with pedestrian sheds. Adapted from "Urban nuclei and the geometry of streets: The 'emergent neighborhoods' model” by Mehaffy, Porta, Rofè \& Salingaros, 2010, Urban Design International, 15(1), p. 42.

Figure 17: 2014 aerial photo of same as above section of Tel Aviv, Israel showing the closely adopted Geddes plan (Google Earth image).

Figure 18: Portland, OR with proposed neighborhood centers and '20 minute neighborhoods. From City of Portland, \& Portland Bureau of Planning and Sustainability (BPS), 2014.

Figure 19: Clarence Perry's destinations of residents in neighborhoods and downtowns. Adapted from Neighborhood and Community Planning by Perry, 1929, p. 87.

Figure 20: 722 SW Morrison Street next to Pioneer Courthouse Square in Portland Oregon (Google Earth Street View, 2014).

Figure 21: Walkable environment on Morrison Street early in the morning in Portland, Oregon (E. Evangelopoulos, personal photograph, August (2006).

Figure 22: Benicia form-based code Town Core zoning standards. From Downtown Mixed Use Master Plan. Ci.benicia.ca.us., by City of Benicia, CA, 2007. p. 4-6 and Opticos Design, Inc.

Figure 23: Farmers Branch Station Area in Relation to the City of Farmers Branch and the Rail Line from Dallas. From Farmers Branch Station Area Conceptual Master Plan by the City of Farmers Branch, TX, 2002, p. 2.

Figure 24: Farmers Branch Station Area Illustrative Plan. From FormBased Code Station Area Ordinance 2800 by the City of Farmers Branch, TX, 2005, p. 10. 
Figure 25: Benicia Downtown Illustrative Framework Plan. Adapted from Downtown Mixed Use Master Plan. Ci.benicia.ca.us., by City of Benicia, CA, 2007. p. 3-3.

Figure 26: City of Benicia Downtown Regulating Plan. Adapted from Downtown Mixed Use Master Plan. Ci.benicia.ca.us., by City of Benicia, CA, 2007. p. 4-3.

Figure 27: Northwest St Lucie County Towns Villages and Countryside (TVC) Master Plan showing proposed configurations of new urban areas with a clear center and edge. Adapted from North St. Lucie County Charrette by St Lucie County, \& Treasure Coast Regional Planning Council, 2004, p 2. ...109.

Figure 28: St. Lucie County Towns, Villages and Countryside (TVC) 5 minute walk neighborhood structure illustrative plan. Adapted from Towns, Villages and the Countryside A New Pattern of Settlement for North St. Lucie County, by St Lucie County, \& Treasure Coast Regional Planning Council, 2006, p. 3-12.

Figure 29: New retail/workplace uses located at key inter-sections of the future transportation system in St. Lucie County. transportation network with a requirement for their placement to not exceed 1/4 mile from the indicated intersection. Adapted from Towns, Villages and the Countryside A New Pattern of Settlement for North St. Lucie County, by St Lucie County, \& Treasure Coast Regional Planning Council, 2006, p. 3-16.

Figure 30: St. Lucie County sample regulating plan showing center, lot densities and a rural/natural edge Adapted from Ordinance No. 06-017 by St. Lucie County, 2006, p.18.

Figure 31: Southeast Lee County (outline in red) showing high amount of rural and natural areas in comparison to the urbanized western Lee County. Adapted from Google Earth imagery.

Figure 32: Lee County, FL Compact Communities Code sample illustrative plan. From Lee County Land Development Code (LDC), Chapter 32 - COMPACT COMMUNITIES by Lee County, FL, 2014, p. 32-34.

Figure 33: Lee County, FL Compact Communities Code sample regulating plan. Adapted from Lee County Land Development Code (LDC), Chapter 32 - COMPACT COMMUNITIES by Lee County, FL, 2014, p. 3-34.

Figure 34: Lee County, FL. Compact Communities Code conceptual regulating plan with 5-minute walk indicator scale on the lower right. Adapted from Lee County Land Development Code (LDC), Chapter 32 - COMPACT COMMUNITIES by Lee County, FL, 2014, p. 32-49.

Figure 35: Identified and delineated .25 and .5 mile walkable neighborhoods with neighborhood centers as part of the Cincinnati Comprehensive Plan up- 
date and form-based code efforts. Adapted from Download Plan Cincinnati. Plancincinnati.org. by the City of Cincinnati, 2013, p. 86.

Figure 36: Sample Regulating Plan showing .25 mile radius superimposed over a neighborhood center and assigned transects. Adapted from Complete Neighborhoods, Citywide Form-Based Code Charrette: Summary Report, by the City of Cincinnati, OH \& Opticos Design, Inc., 2012, p. F.21..128

Figure 37: Example of blocks with a diversity of building types in the Cincinnati Code for T4 transects. Adapted from Final Draft of Cincinnati FormBased Code - City Planning \& Buildings. Cincinnati-oh.gov., by the City of Cincinnati, 2014, p. 6-15.

Figure 38: Thoroughfare assembly standards and specifications in the Cincinnati Form-Based Code. Adapted from Final Draft of Cincinnati Form-Based Code - City Planning \& Buildings. Cincinnati-oh.gov., by the City of Cincinnati, 2014, p. 7-14.

Figure 39: Illustration showing desired pedestrian-oriented streetscape in Peoria, IL. Adapted from Publications. Appendix C - Heart of Peoria Land Development Code. Municode.com. by the City of Peoria, IL, 2014b, p. 1.

Figure 40: Heart of Peoria Regulating Plan. Adapted from Publications. Heart of Peoria Plan. City of Peoria, Illinois. Peoriagov.org. by the City of Peoria, IL, 2002, p. III.6.

Figure 41: Heart of Peoria Plan identification of neighborhood centers and pedestrian sheds. Adapted from Publications. Heart of Peoria Plan. City of Peoria, Illinois. Peoriagov.org. by the City of Peoria, IL, 2002, p. II.4.

Figure 42: Correspondence of pedestrian sheds (yellow circles) identified in the Heart of Peoria Plan with pedestrian-planned zones (various types of commercial and form-based areas, outlined in blue) in the Zoning District Map. Adapted from Publications. Heart of Peoria Plan. City of Peoria, Illinois. Peoriagov.org. by the City of Peoria, IL, 2002, p. II.4. and City of Peoria Zoning District Map, by the City of Peoria, IL, 2008.

Figure 43: West Main Street Regulating Plan. Adapted from Publications. Appendix C - Heart of Peoria Land Development Code. Municode.com. by the City of Peoria, IL, 2014b, p. 6-15.

Figure 44: West Main Street street standards diagram showing pedestrian accommodations. Adapted from Publications. Appendix C - Heart of Peoria Land Development Code. Municode.com. by the City of Peoria, IL, 2014b, p. 6-41.

Figure 45: West Main Street Neighborhood Center height and siting standards. Adapted from Publications. Appendix C - Heart of Peoria Land Development Code. Municode.com. by the City of Peoria, IL, 2014b, p. 6-16. 


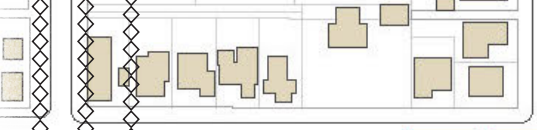

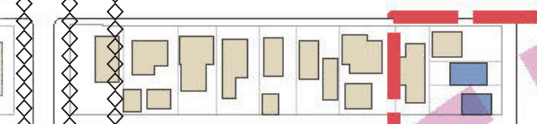

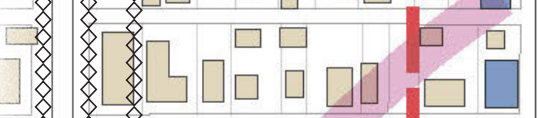

3

(3)

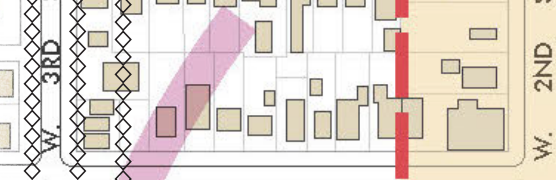

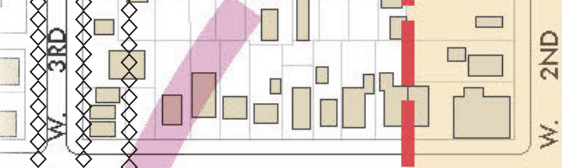

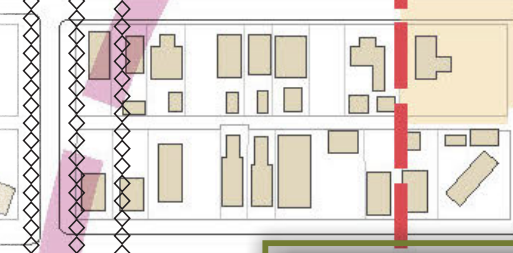

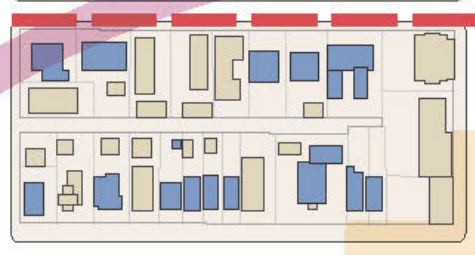

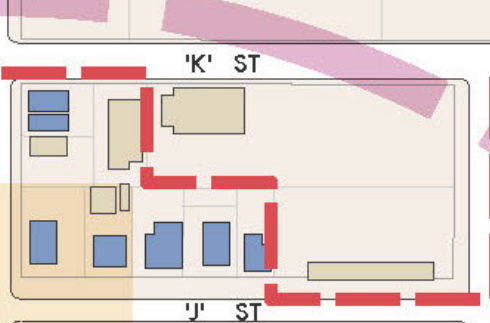

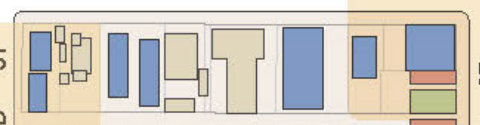

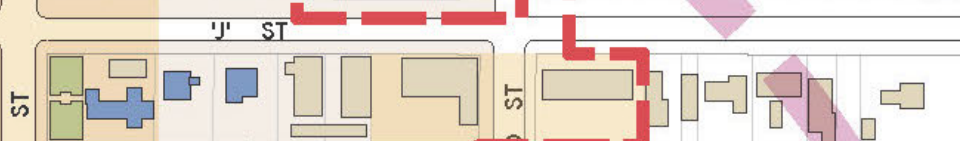

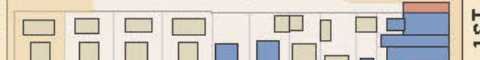

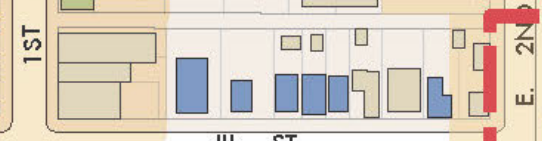

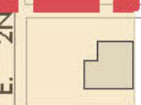

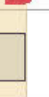

-

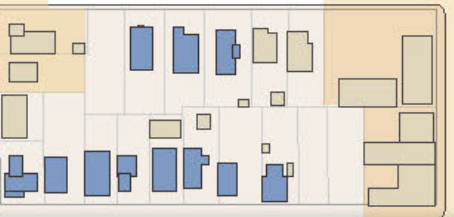

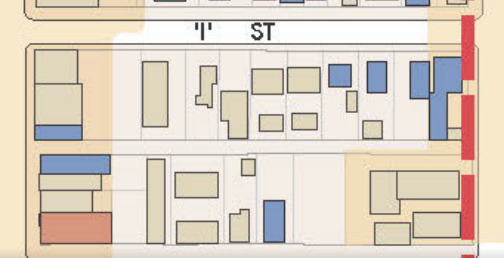

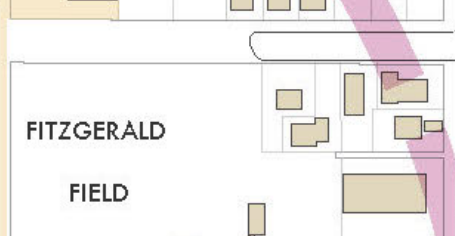

18

NEIGHBORHOODS, PROXIMITY TO

DAILY NEEDS, \& WALKABILITY

IN FORM-BASED CODES

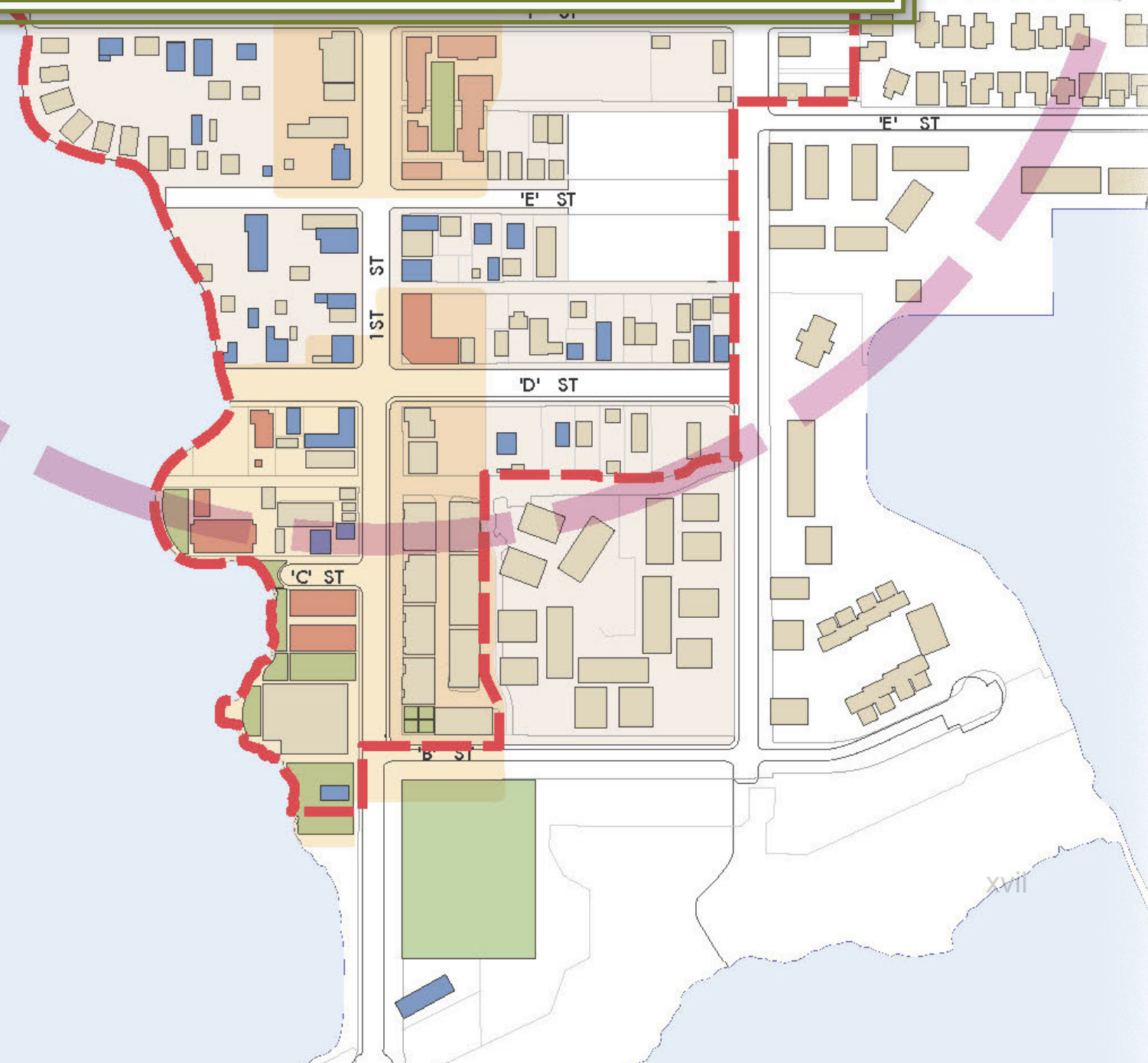




\section{NEIGHBORHOODS, PROXIMITY TO DAILY NEEDS, \& WALKABILITY \\ IN FORM-BASED CODES}

\section{INTRODUCTION}

\subsection{Form-Based Codes}

Polyzoides (2008) describes form-based codes as a regulating and coding method that supports a place-based urbanism and planning. Such place-based codes contrast with use-based Euclidean codes that create a chaotic urbanism of "congestion, ugliness, impermanence and petroleum dependence" (Polyzoides, 2008, p. xv). Communities that adopt form-based codes can enjoy the benefits of place-based urbanism and planning.

Every year the Form Based Code Institute issues the prestigious Driehaus Award to the best form-based codes in the country with the support of the Richard H. Driehaus Charitable Lead Trust (Form-Based Code Institute, 2014d). In addition, qualified form based codes from all over the country are selected and listed in the Library of Codes page of the FormBased Code Institute (Form-Based Code Institute, 2014b). Form-based codes are evaluated mainly on criteria listed in the FBCl web-page (Form-Based Codes Institute, 2014c).

\subsection{Problem Statement}

Both the evaluation criteria and the official definition of form-based codes contain many commonly accepted planning terms (i.e. guidelines, regulations, standards, building facades) in addition to other more ambiguous terms such as 'high quality public realm,' 'physical form,' 'integrated built form,' 'appropriate form and scale,' 'character,' or 'time 
tested forms of urbanism' that can contribute to a misunderstanding of the scope and intentions of form-based codes. Similarly ambiguous terms are, 'a focus primarily on regulating urban form and less on land use,' 'promote and/or conserve an interconnected street network and pedestrian-scaled blocks,' and 'walkable, identifiable neighborhoods that provide for daily needs.' If, for example, a high quality public realm and a walkable neighborhood were associated with specific urban principles and standards, evaluation of form-based codes will be clearer and misunderstandings limited.

Terminology variability, the balance between standards and recommendations or guidelines, and a high amount of waivers can also contribute to the limited effectiveness of a form-based code. A comparison of the Benicia, CA with the Azusa, CA form-based codes for example shows significant differences in structure, terminology and standards utilized. In Addison, TX, the high amount of waivers can minimize the effectiveness of the formbased code and contribute to an undesirable and unpredictable urban form.

\subsection{Hypothesis and Relevance}

There is a general attempt to adapt zoning codes to new demands and realities such as walkability, sustainability, commuting time reduction, and infrastructure efficiency. New Urbanism, Smart Growth and form-based codes represent such attempts during the past decades to reform zoning regulations in US cities and respond to the inefficiencies of traditional Euclidean zoning. A large part of the theoretical framework of form-based codes derives from the need for reform, the intentions of the reformers, the crafting of codes and the application of the new codes (Talen, 2012). 
As of 2012 , after more than a decade of implementation, only about $.2 \%$ of US cities have adapted form based codes (Rangwala, 2013) and this rate is extremely slow when compared to the rate of zoning adaption by US cities after the 1916 New York City zoning law (Talen, 2012). Clarifying concepts and intentions of form-based codes can speed up the rate of implementation and diminish controversies and misconceptions.

The hypothesis of this work is that identifying and exploring the intentions of form-based codes will provide specific measurable parameters to assist code evaluation. An additional outcome is the creation of a checklist of parameters linked to quality of life to assist both practitioners and the public and avoid misconceptions about form-based codes.

\subsection{Chapter Content}

Next chapter, Chapter 2, introduces the concept and history of zoning in the United States along with a history and criticism of the omnipresent use-based zoning. The same chapter, clarifies the concept of form-based zoning and describes two of the main differences between form-based zoning and use-based zoning: neighborhoods and zones of urban intensity vs zones of use, and regulating plans vs land-use maps.

Chapter 3, explores and identifies the intentions of form-based codes. The first intention is improving the quality of life in neighborhoods, communities, towns, and cities which is the main focus on this thesis.

Chapter 4, first explores and identifies three urban principles associated with quality of life in form-based codes: 
- Neighborhood with a clear center and an identifiable edge.

- Proximity to daily needs.

- Walkability.

Parameters for every principle are then identified in the form-based code literature. The presence of these parameters is tested in six award-wining form-based codes and the findings are discussed. Chapter 4 concludes on the importance of the findings in formbased codes and their evaluation and suggests possible further steps. 


\section{ZONING}

\subsection{IMPACT OF ZONING ON THE LAND}

Zoning and zoning regulations are a component of public policy that along with management and design represent the triad of controls that shape land development (see Figure 1). The individual impact of these three land controls may vary among environments (Plater-Zyberk E., 2008):

- Policy represents "the legal framework that establishes the intent for the desired relationships and performance of places"

- Management ensures cleanliness, safety, maintenance and desired performance of environments

- Design facilitates management by providing the right kind of relationship between physical components of the land

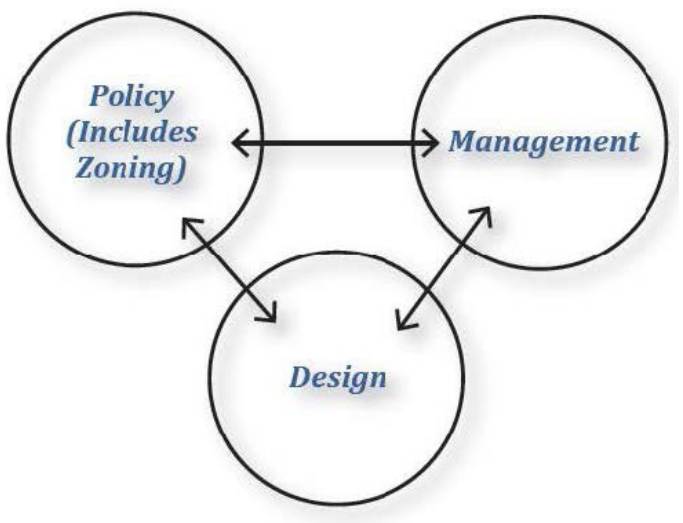
Figure 1: Diagrammatic depiction of the triad of controls that shape land and building development according to Platter-Zyberk E. (2008).

and defines desired character (Plat-

er-Zyberk E., 2008, p. ix).

Urban regulations start from the need to address issues such as fire safety, vehicular circulation, access to light, public health, use conflicts, and visual harmony (Talen 2009). Urban regulations and rules include ordinances, zoning, and deeds and restrictions. 
- Generally ordinances affect several types of activities in cities in relation to public health, safety, and general welfare of people and property.

- Zoning regulations are ordinances affecting the use of land and are the most common form of land regulations in the US enacted by local governments while

- Deeds and restrictions are imposed by land owners and developers (Mixon, Dougherty Jr. \& McDonald, 2013).

Zoning divides the city into districts (zones) each with distinct regulations and is an exercise of police power to implement such regulations. In the US this is reflected in the power to implement the comprehensive, general or subdivision specific plans and the zoning codes associated with their implementation. (Meck, 1996, Repps, 2014).

Zoning is a tool to implement certain ideas about the development of a city. Zoning codes, often unseen to many people, impact almost every aspect of our lives. They shape a certain urban environment by impacting such specific aspects as building heights, building types, building placement, road widths, or location of uses and every day issues such as street traffic, the availability of a parking spot, the safety and enjoyment of a walk and the houses we live in, (Duany, 2009). Fischel (1985) asserts that:

Zoning and other land use controls influence the location and combination of labor and capital. They can have a far greater influence on economic and other social activity than might be indicated by the fraction of land affected or the share of rent in national income. Land use controls can affect the quality of the environment, the provision of public services, the distribution of income and wealth, the pattern of commuting, development of natural [17/18] resources, and the growth of the national economy. The notion that zoning is just a matter of local concern is incorrect when the cumulative effect of these regulations is considered. (p. 19) 
According to Talen (2012), zoning regulations significantly shape three aspects of cities over time (see also Figure 2):

- Pattern that corresponds to the two dimensional layout of the city, the streets, the blocks and the lots,

- Use that deals with the issue of what use is located where addressing a fundamental component of zoning, nuisance, and

- Form that concerns the three-dimensional form of the city and defines space using such rules as setbacks, building lines, lot coverage and street parameters such as trees and sidewalks, instrumental in the definition of urban space.

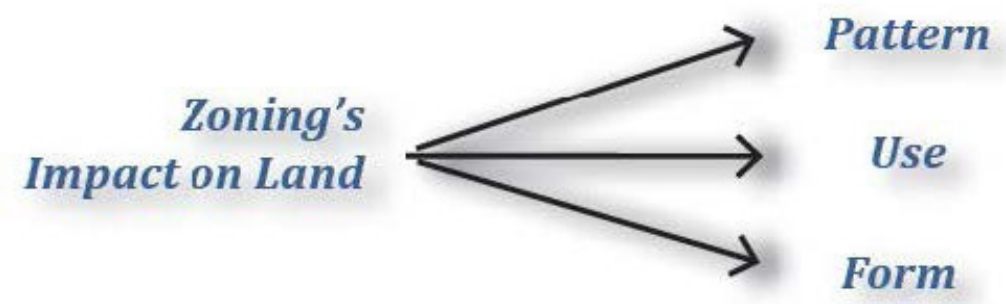

Figure 2: Diagrammatic depiction of the three impacts of zoning on land according to Talen (2012).

\subsection{History of URban Regulations}

The history of urban regulations is long addressing both urban form and use. In Roman times for example, regulations affecting urban form dealt with street size and building height to minimize wind impact on dusty streets and avoid street shading by tall buildings. In the City of Rome, Julius Cesar restricted the height of buildings to minimize obstruction of sunlight. During Medieval times in Europe, aspects of the urban environment regulated, were building heights, building type, distances between buildings, embellishment, window size, street width, and setbacks (Talen, 2009). The Laws of the Indies enacted by King 
Phillip the II of Spain in the 16th century, guided urban development in the Spanish colonies of the Americas, and addressed in detail the form of the urban environment.

Codes have also regulated uses if perceived incompatible with urban spaces or other uses. Keeping industrial buildings and functions separate is an example of zoning practiced since ancient times. Talen (2009) mentions restrictive laws in both ancient Rome and 17th century London that kept industry out of central areas or other city parts.

By the late 1800's there was already a significant history of building ordinances and regulations in Europe and European cities more frequently embraced regulations. US efforts at the time were scattered and isolated such as New York's Tenement House Act of 1867 applied to one only type of city building (Talen, 2009). However, it was becoming more apparent that a more coordinated approach was necessary to address challenges of the 1800's rapid city expansions such as sanitation, infrastructure, housing and open space (Freestone, 2001).

According to Talen (2012) zoning was invented by the German engineer, Reinhard Baumeister in the 1870's and applied to cities like Frankfurt and Cologne separating the entire city into zones of land value and intensity. A city is composed of diverse neighborhoods and districts. Although a building code applies regulations uniformly throughout the city, zoning is place or zone-specific. Zones of different urban regulations seemed necessary at the time and the solution, zoning, is described as "planning in recognition of the differences in different parts of the city" (Talen, 2012, p. 21). 
Following the German tradition, the Proceedings of the Fifth National Conference on City Planning in 1913 in Chicago, published model acts enabling States to delegate police authority to municipalities for planning and zoning. As a result, even before the Standard Zoning Enabling Act of 1926, States had started to give authority to municipalities to legislate for planning and zoning. New York City was the first to adopt a comprehensive zoning ordinance in 1916 (Meck, 1996, Evans, 2009, Repps, 2014). The Euclid vs Ambler court decision (1926) and the Standard Zoning Enabling Act (1926) provided the final big impetus for the expansion and prevalence use-based zoning in the US (Emerson, 2006).

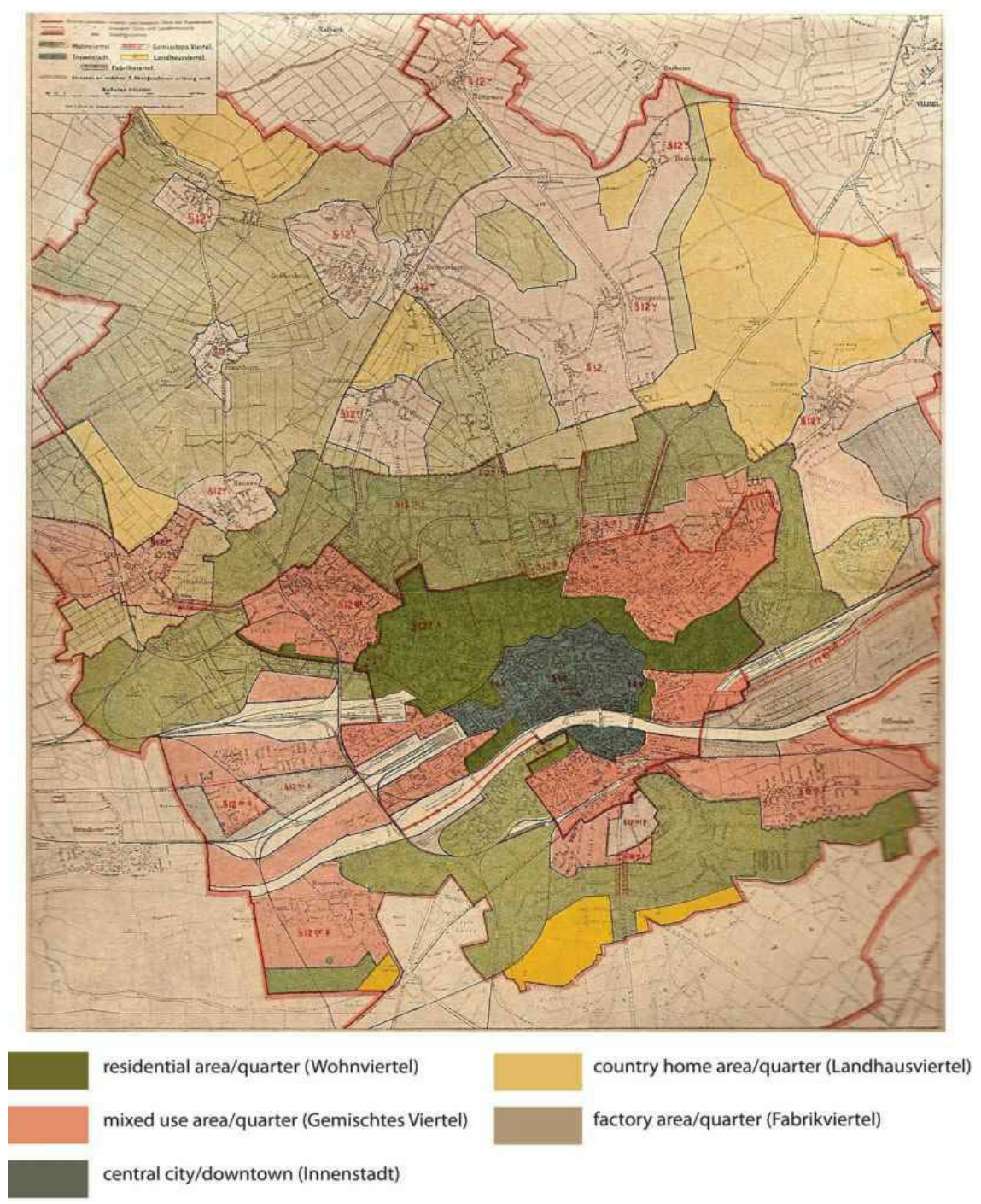

Figure 3: The first zoning code in Frankfurt, Germany in 1891. From City Rules, How Regulations Affect City Form, by Talen E., 2012, p. 30. 


\subsection{Use-Based Codes}

\subsubsection{Used-Based Zoning Legislative Authorization}

\section{Use-based Zoning Beginnings}

According to Parolek, D., Parolek, K., \& Crawford, P. (2008), zoning slowly evolved to outline exclusive use-based zones out of the need to minimize fire spread by separating buildings and uses, and provide for more sunlight. Smoke producing industries were slowly separated from residential development to minimize fire threats. This slowly resulted into the exclusive separation of uses within a city as single-family, commercial, and industrial uses were segregated and deemed incompatible. Separating uses resolved many problems and contributed to the health and welfare of urban dwellers. The first such example of used-based regulations separating future uses is from 1904 in Los Angeles where the intent was to protect property values and exclude undesirable uses (Parolek, D., Parolek, K., \& Crawford, P., 2008).

Emerson (2006) adds that a reason of use-based zoning prevalence in the 20th century is the highly glamorized and advertised suburban lifestyle of the post-World War II years. This was also the era of Modernism that influenced perceptions and practices. Caliskan and Marshall (2011, p. 381) say that Modernism created an urban vision that emphasized not only separation of uses but an urban form based on negative space creating "modernist-style urban fabrics" in contrast to "contemporary designs based on an appreciation of traditional urban fabrics" by neo-traditional urbanists. 
Although use-based zoning created expansive automobile-dependent suburban areas, suburbs themselves are not the result of use-based zoning. Suburbs in some form or another have always been part of the American experience long before automobiles but differed in plan and design from suburbs created with use-based zoning codes (Emerson, 2006).

These still are the predominantly used zoning codes today and every single-use zone is regulated by a distinct set of zoning standards (Evans, 2009). Additional overlaying of zoning districts can span over single use districts addressing slopes, wildlife, hydrology, building heights or historic elements.

\section{Supreme Court and Federal Government Endorsement}

Use-based zoning is also known as Euclidean Zoning, so named after the 1926 Supreme Court case The Village of Euclid v. Ambler Reality Co., 272 U.S. 365. The court decision was instrumental in the expansion of current practices of exclusive use separation. Inniss (2007, p. 87) comments that "this case established the constitutionality of comprehensive zoning" and accepted use-based zoning as reasonable and non-arbitrary, substantially relating to "public health, safety, morals, and general welfare."

Despite however upholding single-use zoning, the Euclid Court expressed reservations regarding use-based zoning effectiveness. Emerson (2006), says the Euclid Court, although upheld the adoption of zoning in urban areas, were reserved, ambiguous, and decidedly inconclusive regarding use-based zoning legality in rural areas. Emerson comments that the Euclid Court included a "transect-oriented statement into its analysis of use-based zoning" (Emerson, 2006, p. 656) and adds the following Euclid Court analysis excerpt: 
Thus the question whether the power exists to forbid the erection of a building of a particular kind or for a particular use . . . is to be determined, not by an abstract consideration of the building or of the thing considered apart, but by considering it in connection with the circumstances and the locality. A nuisance may be merely a right thing in the wrong place, like a pig in the parlor instead of the barnyard. (p. 656)

The Euclid Court also remarked that zoning "would inevitably end up segregating some industrial uses that themselves were not a nuisance vis-à-vis their proximity to residential uses" (Emerson 2006, p. 657) and acknowledged such strict land use distinctions as unavoidably incapable of addressing the gray area between good and bad.

The US Government followed the court decision and during the same year, the Standard Zoning Enabling Act of 1926 "authorized the local jurisdiction to divide the municipality into 'districts' that correspond to the types of regulated land uses." The act was not only a government approval of use-based zoning but also a reaction to the urban conditions of the era (Emerson 2006, p. 653).

\subsubsection{Criticism}

Perceptions however, shifted over the years as the adoption of single-use zoning seemed less effective in contributing to the health and welfare of people than traditional urban design. Over the last decades of the 20th century, many critics started objecting to single-use zoning and the urban forms it produced. First, technological advances have resolved many of the fire and health issues associated with compact city conditions and over-crowding (Emerson, 2006). Then, comparing the traditional urban landscapes of the 19th and early 20th centuries to the use-based Euclidean zoning landscapes of the late 20th century critics were observing a lack of important urban qualities creating unfavorable conditions for humans and stretching out city resources. Boyer 
(2010, , p. 1) says that "many experts argue that conventional codes, built on the Euclidean zoning of uses, create a physical landscape that is not suited to optimal human movement, use, and enjoyment."

Reflecting both Duany's (2009) and Talen's (2012) concerns, Euclidean codes impact the triad of concerns that shape land development: land policy, management and design impacting both the two- and three-dimensional aspects of a city. At the street level, Euclidean codes impact the free and rapid flow of traffic, parking quantities, and the rigorous separation of building uses (Duany, 2009). Adding the two together, on both the broader policy and street levels Euclidean Zoning results in:

a. The creation of what can be referred to as unfriendly urban human habitats, and

b. The promotion of inefficient and unsustainable cities

\section{Unfriendly Human Habitats}

In 1926, the Euclid Court recognized that by splitting land into exclusive use areas, uses useful to everyday life, not constituting a nuisance, would be excluded from residential areas. Since the court could not take on the responsibility of identifying all such uses and the public opinion trend was towards use-based codes, the court upheld Euclid's zoning ordinance (Emerson, 2006). However, such concerns about daily urban life eventually became more pronounced.

Rob Krier (1979, p. 79) comments on separation of uses in cities that, "we have come to realize today that this theory of the compartmentalization of function has had a negative 
influence on urban life. From the point of view of urban space the connections between the various elements are only fragmentary and do not add up to an integrated system."

Other urban theorists of that era, such as Jane Jacobs (1961), Christopher Alexander (1977), Kevin Lynch (1984), and place-oriented theorists such as Yi Fu Tuan (1984), Relph (1976), Kevin Lynch (1976), David Seamon (1980), and Norberg-Schulz (1980), criticized the sprawling subdivision developments and loss of traditional town design as an attack on community, sense of place and quality of life.

Another vocal critic of use-based codes Paul Murrain (2009), comments that a rethinking of our urban environment is imperative to better serve human needs, and calls for a new type of zoning codes to keep the town together. Emerson (2006) argues Euclidean Codes do not facilitate human habitat while Parolek, D., Parolek, K., \& Crawford, P. (2008) harshly criticize current zoning practices and sprawling land patterns as detrimental to our physical and mental health, communities and environment. The authors emphasize the negative impact of use-based codes on the quality of public realm due to lack of vibrant centers, civic interaction, and sense of place.

\section{Inefficient and Unsustainable Cities}

Emerson (2006) describes use-based zoning as inefficient, creating unsustainable cities and frustration among planners and practitioners. First, it was impossible to implement any of the traditional urbanism principles that create a main street, or a town in the form of Savannah, San Fransisco or Philadelphia. Then, the separation and exclusion of uses, discounted needs for proximity to daily necessities, increased travel distances, dependency on the car and stretched infrastructure. The resulting long commuting 
times deprived city dwellers of a more efficient lifestyle with shorter trips and experientially richer environments.

Parolek, D., Parolek, K., \& Crawford, P. (2008) mention that the shortcomings of use-based codes were becoming obvious as early as the 1950's. Use-based codes separated workplaces and shopping from residential areas requiring extensive travel between different uses while the prevalence of single-family housing consumed large tracts of land increasing travel distances even more.

The increased travel between uses, a result of increased distances due to high land consumption of expansive single-family residential uses resulted in increased automobile traffic. The streets are automobile-oriented and there is a never-ending attempt to accommodate an ever-increasing traffic. Such claims contrast single-use zoning to current concepts of sustainability and prompt the need for a different approach to land-use.

Real Estate Corporation (1974), lists capital and operating economic costs, environmental effects, and personal effects of suburban sprawl. The authors mention higher costs for utilities, public facilities and services, higher land consumption, air and water pollution, water and energy consumption, increased commuting time, traffic accidents, and psychological effects.

Plater-Zyberk (2008) adds that:

As global society swings into action to reduce carbon emissions, the data ever more clearly points to the need to reduce dependence on vehicular mobility, and to remake the built environment as a transit- and pedestrian-friendly place of dense economic and social interaction. (p. xii) 
Use-based codes focus around the automobile and create automobile-oriented landscapes while the old admired walkable towns such as Annapolis, Key West or Savannah are impossible to recreate within a Euclidean zoning system and "only a form-based code can ensure such an urbanism" (Plater-Zyberk, 2008, p. xii).

Such calls by professionals and academics slowly gave rise to suggested alternatives to Euclidean Codes and eventually to the current form-based code movement.

\subsubsection{Suggested Solutions and Form-Based Zoning}

Critiques gave rise to temporary fixes such as performance or incentive zoning (Parolek, D., Parolek, K., \& Crawford, P., 2008). Form-based codes and the SmartCode provided another approach by allowing mixing of uses that favor the creation of a community and support daily aspects of human life as running for errands, having a richer daily experience, and providing pedestrian friendly environments with multi-modal transportation options. Re-establishing the ability to design such environments was seminal in the effort to redesign zoning codes (Emerson, 2006).

Aspects of urban life characteristic of traditional American towns such as Savannah or Annapolis create a sense of community and support daily community life (Duany, 2009). Form-based codes rose out of an inability and illegality to design such traditional-style environments with use-based codes. Many municipalities were attempting to revitalize, create economically viable areas, attract pedestrians, address sustainability, smart growth and local character often increasing housing densities and existing codes were unable to facilitate such aims. Parolek, D., Parolek, K., \& Crawford, P. (2008) mention that such 
a change in expectations from zoning contributed to the emergence of the new formbased zoning approaches.

Florida and Miami were instrumental to the rise of such new zoning solutions. One of the reasons is the presence of fabled communities such as Key-West and Coral Gables urban environments that could not be emulated under Euclidean coding (Emerson, 2006).

The first attempt was at Seaside in northern Florida, followed by Traditional Neighborhood Zoning Ordinances and the SmartCode. The SmartCode, created by Andres Duany, a Florida-based architect, is the first ambitious attempt to completely replace Euclidean coding with a new format and create better urban environments. The SmartCode is a template form-based code attempting a more thoughtful layout of cities based on traditional urban principles contributing to quality of life. By definition the SmartCode incorporated the principles of Smart Growth and New Urbanism (Menard, 2009). 


\subsection{Form-Based Codes}

\subsubsection{Neighborhoods and Zones of Urban Intensity}

Unlike Euclidean Codes, form-based regulations do not create zones of use. Form-based regulations create zones of urban intensity that range from less urban to more urban within urban units with an identified center and edge (Talen, 2012). While the concept of transect helps organize urban intensity in a longitudinal section, in plan view, a multitude of similar urban intensity levels scatter throughout an urban area requiring an additional organization method. As a result, in plan view, and across an urban area, transects are organized within urban units often referred to as neighborhoods with a center and an edge. Within each neighborhood, urban intensity zones, as transects, are carved out with the center of the neighborhood assigned a higher intensity transect. Often neighborhoods are assigned to even larger areas that help comprehension and organization in terms of open space, character, walkability and specialized districts.

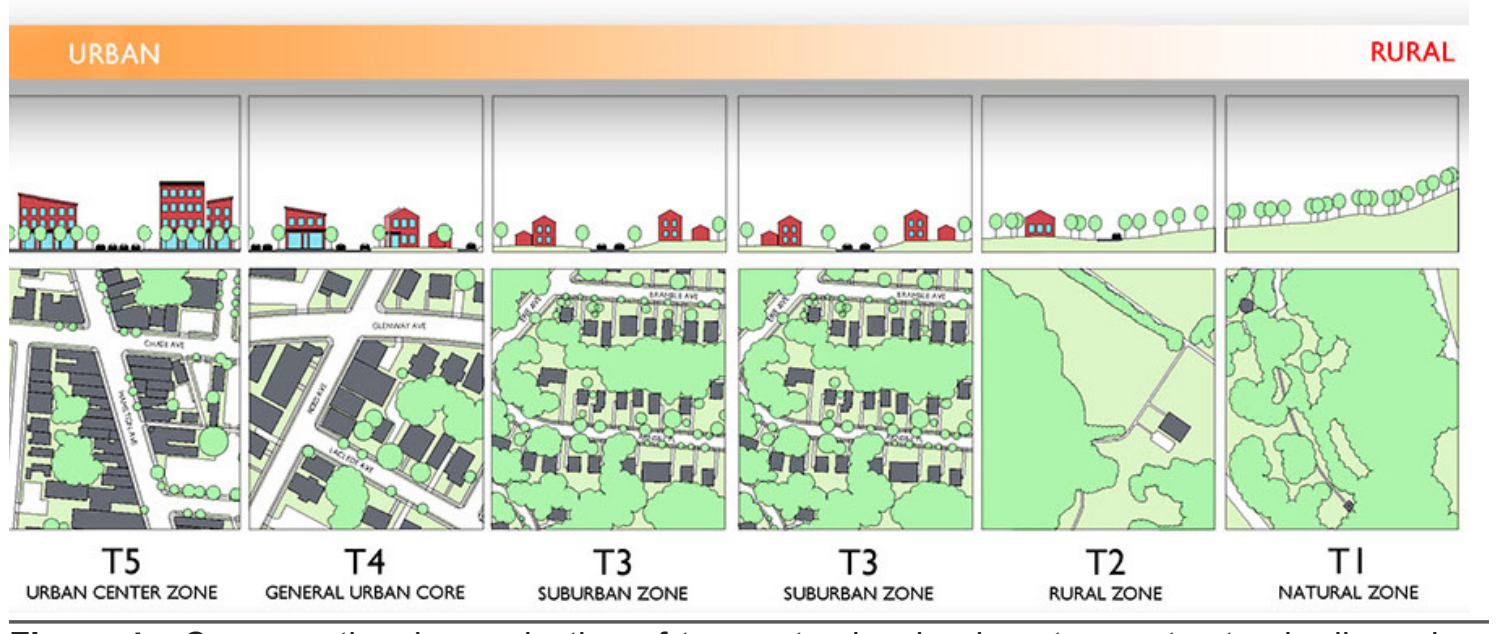

Figure 4: Cross-sectional organization of transects showing how transects standardize urban intensity gradation from dense urban core to rural and natural. According to form-based codes, every transect creates a separate coding zone. Adapted from Urban Design/Planing - FormBased Codes by Glaserworks, 2014. 
With transects, neighborhoods are broken down into a series of coding areas paying attention into creating smooth transitions between urban intensity zones instead of sudden or buffered separations applied when use-based coding zones are applied (Parolek, D., Parolek, K., \& Crawford, P. 2008, p.18). Urban intensity refers mostly to the size of buildings, amount of the lot occupied by buildings and density of uses and population.

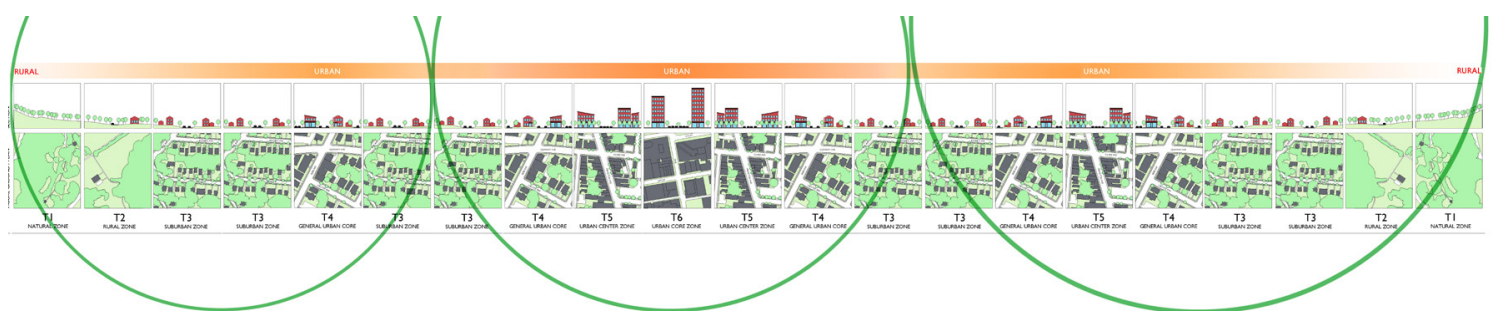

Figure 5: Typical urban area cross-sectional organization and gradation of transects within neighborhoods (red circles). Neighborhood radii are usually that of the 5 minute walk (.25 miles) but it can vary up to a mile sometimes. Note that in the neighborhood on the right the center is to the left. Location of centers can vary depending on the conditions. Adapted from Urban Design/Planing Form-Based Codes by Glaserworks, 2014.

The transect as a concept represents a gradation of urban intensity from the urban core (Transect 7 ) to the suburban (Transect 4), rural (Transect 5) and natural (Transect 1). At its most basic application a transect represents an urban intensity zone with separate coding standards within a delineated neighborhood area (Parolek, D., Parolek, K., \& Crawford, P. 2008). As a spatial organizing principle of the codes it corresponds to the requirement in neighborhoods for a center with denser development, mixed use, civic buildings, and stores for residents satisfaction of daily needs. It reflects the general notion of neighborhood having mixed-use centers gradually radiating into less dense and more rural development. Every neighborhood unit may have all or some of the urban intensity transects.

Polyzoides, (2008, p. xvi) relates the transect to the concept of neighborhoods and adds that, "the geography of neighborhoods, districts and corridors replaces the endlessness 
of sprawl with the idea of regulating within clear, identifiable spatial boundaries." Parolek, D., Parolek, K., \& Crawford, P. (2008, p.18) add that the transect classifies and organizes "the human habitat in a continuum of intensity that ranges from the most rural condition to the most urban."

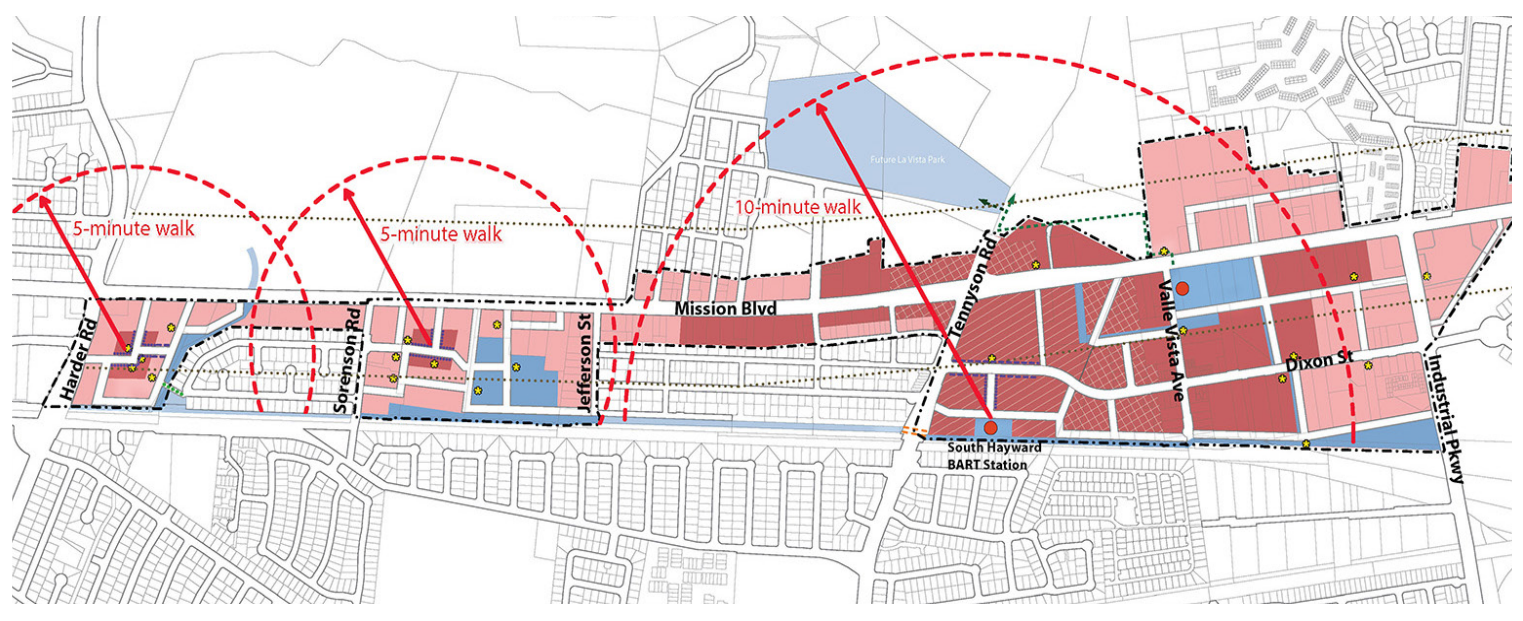

Figure 6: Plan-View organization of transects. City of Hayward, CA form-based code regulating plan showing 5 and 10 minute walk delineations with marked centers as higher density transects. From City of Hayward, CA (2011, Para. 3, Figure 1-1: Regulating Plan Map).

\subsubsection{Regulating Plans vs Land-Use Maps}

The land-use map used in Euclidean codes separates land use areas but does not address walkability, create economically viable areas, attract pedestrians, address sustainability, smart growth, or local character. The regulating plan, as a replacement of the land use map, delineates neighborhoods and the levels of urban intensity envisioned in formbased codes providing a vision for communities with economically viable, walkable, richer environments that have the ability to reflect the local character and the desires of the local community. The regulating map includes neighborhoods, districts, corridors, transects but can also include focal points, vistas, street types, and historic buildings. Use remains important but, just like automobiles in a complete street layout, use is just one of an array of tools used to create efficient, pleasant, and sustainable neighborhoods and cities. 

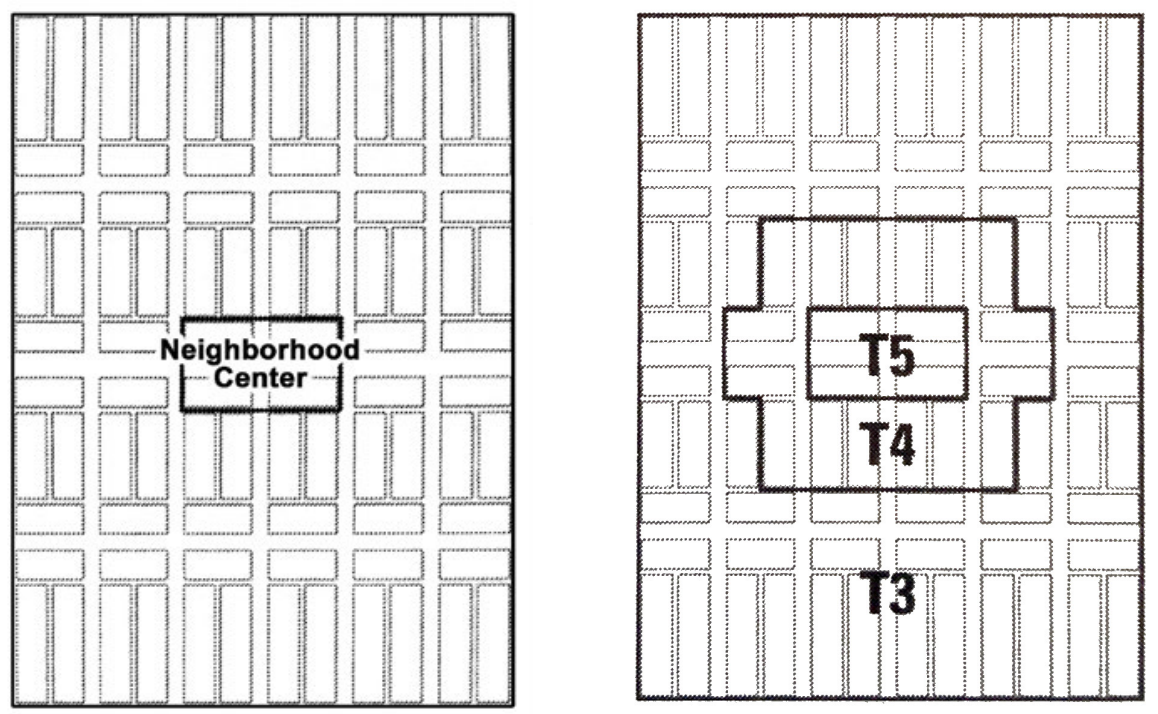

Figure 7: Schematic of a Neighborhood with an outlined center, edge, and assigned urban intensity areas (transects T3 to T5). Adapted from FormBased Codes by Parolek, Parolek \& Crawford, 2008, p. 161.

\subsubsection{Form-Based Codes and the SmartCode}

The SmartCode is a form-based code plan that contains a form-based code supplement (Duany, A., Sorlein, S., \& Wright, W., 2008). The SmartCode includes guidelines and regulations at several scale levels. At a large-scale level, there are sector plans, followed by community types and transect zones, and finally at the building and site levels there are building and site standards. Emerson (2006) restricts the notion of form based codes to the building, block or even the neighborhood and defines the SmartCode as inter-neighborhood, a code that looks at the bigger picture, at the relation between neighborhoods, the urban context and also that urban progression from urban to rural represented by the concept of transects.

However, the term 'form-based code' is lately used to describe a code that addresses all scales, just like the SmartCode. Examples are the Cincinnati Form-Based Code, a 
FBCI Honorable Award Recipient, or the Azusa Development Code in the Los Angeles Metropolitan Area. The Form-Based Code Institute treats the SmartCode as another formbased code included on the list of form-based code examples (Form-Based Codes Institute, 2014b). Such SmartCode examples are the Central Petaluma SmartCode and the Gulfport SmartCode.

According to this approach, SmartCode refers to the specific zoning template created by Andres Duany and DPZ (Duany Plater-Zyberk \& Company Architects \& Town Planners) The term 'form-based code' instead has begun to encompass any code with the characteristics and intentions defined by the Form-Based Codes Institute as:

a land development regulation that fosters predictable built results and a high-quality public realm by using physical form (rather than separation of uses) as the organizing principle for the code. A form-based code is a regulation, not a mere guideline, adopted into city, town, or county law. A form-based code offers a powerful alternative to conventional zoning regulation. (Form-Based Codes Institute, 2014a, para. 1)

The difference between a form-based code and the SmartCode may simply depend on the party using the terms. In this report the SmartCode will be treated as a type of a form-based code. 


\section{FORM-BASED CODE INTENTIONS}

\subsection{Literature ReVieW}

Talen (2009) provides a laconic and succinct summary of form-based code intentions assigning their origin to admiration of cities of the past and clarifies that old codes were simple and sufficient originating from a civic consensus. This civic consensus was the result of vernacular, culture, limited technology, and historical conditions that guided the production of codes and the creation of cities with a sense of place rooted in locality.

Talen adds, however, that today's cities are much more complex than towns of old making it harder to create a simple code with civic consensus through processes of public involvement (Talen, 2009, p. 157). Despite the daunting task, form-based codes intend to achieve a consensus about urban form with shared ideals, be responsive to local conditions by engaging the public in the code making process, and achieve a better sense of place with time-tested forms of urbanism.

Talen's assertions are reflected in the form-based code literature. Prevalent is the reference to the desire to evoke the community's vision and create a code that corresponds to local conditions. Common is also the discussion about achieving a quality of life, quality of public realm, and strong urbanism. Another common mention, is the need to create a unified development ordinance integrating subdivision and public works standards, creating predictability in the code, streamlining the entitlement process, and creating concise and easy to understand codes. 
In summary, Talen (2009) identifies four major areas of intentions:

- Quality of life and quality of public realm.

- Specificity to locality.

- Community vision.

- Creating a better code structure, clarity, and administrative process

Talen's insightful assertions are used as a starting point to organize form-based code intentions in 7 other specialized form-based code sources. Additional categories of intentions are supplemented as needed. The review begins with the Form-Based Codes Institute official page, and concludes with a summary of form-based code intention categories.

\subsubsection{Form-Based Codes Institute (2014c)}

In the Form-Based Codes Institute evaluation criteria web page (Form-Based Codes Institute, 2014c), four major areas of intentions are identified:

Quality of Life and Quality of Public Realm

Urban form and quality of public realm are linked to quality of life and an introductory video on the same web page (Form-Based Codes Institute, 2014c), comments that form-based codes intend to affect the quality of our lives with the regulation of urban form that shapes the lives of our communities. Urban form qualities that contribute to a high quality public realm are related to time-tested forms of urbanism and include regulations and standards 
that control the features, configurations and functions of buildings that define and shape the public realm such as:

- Making buildings face streets and contribute to the public realm.

- Controlling the form and mass of buildings in relation to one another.

- Creating welcoming facades.

- Using coordinated standards for an integrated built form.

- Matching street and building designs.

- Using the original building and street form of small towns.

- Using an appropriate scale and type for streets and blocks.

\section{Specificity to locality}

Form-based codes intend to adapt the code to the location at hand.

\section{Community Vision}

Form-based codes intend to achieve a community vision based on time-tested forms of urbanism.

\section{Structure, Clarity, and Efficiency of the Code and Development Process}

Form-based codes intend to:

- Designate in the regulating plan form and scale and not only distinctions of land use.

- Create predictable built results.

- Regulate and not just advise. 
- Have a clearly defined and streamlined application and project review process.

- Use both words and diagrams for clarity.

\subsubsection{The Chicago Metropolitan Agency for Planning (2014)}

In the Chicago Metropolitan Agency for Planning form-based code manual (Chicago Metropolitan Agency for Planning, 2014), six major areas of intentions are identified:

\section{Quality of Life and Quality of Public Realm}

Form-based codes intend to create livable communities with a focus on the physical character of the development and how it relates to the public realm.

Overall the handbook by The Chicago Metropolitan Agency for Planning, (2014) is part of the effort to make Chicago a better place to live and form-based codes are touted as part of this effort to create livable communities (Chicago Metropolitan Agency for Planning, 2014, p. 5).

\section{Specificity to Locality}

Form-based codes intend to tailor development to reflect local architecture, the overall character of place, and the local sense of place by emphasizing streetscape design, individual building character in defining public space, and visual aspects of the community so the development fits within the existing context. The result is a focus on the context of the surrounding community, and the relationships between the streets, the building, pedestrians, and vehicles. 
In addition, form-based codes intend to tailor development to the local community objectives and means that include the local political landscape, the financial and staff resources available to support the effort, goals for preservation or transformation, and existing physical character.

\section{Community Vision}

Form-based codes intend to preserve what the public wants and cherishes and prevent what the public does not want by regulating the physical form and character of new development, "rather than reacting to those elements of each development proposal on a piecemeal basis (or not at all)" (Chicago Metropolitan Agency for Planning, 2014, p. 11).

Structure, Clarity, and Efficiency of the Code and Development Process

Form-based codes intend to:

- Provide transparency and predictability in zoning and the zoning process.

- Provide concise information by crafting zoning codes that are shorter, more concise and emphasize illustrations.

- Intend to regulate land use more broadly.

\section{Walkability, Satisfaction of Daily Needs}

Form-based codes intend to make possible to walk for daily errands such as get a quart of milk, reduce the need to travel extensively as part of one's routine, and enable more efficient public transportation. 


\section{Development Character}

Form-based codes intend to emphasize the physical character of the development.

\subsubsection{Duany, A., Sorlein, S., \& Wright, W. (2008) (The SmartCode)}

In the SmartCode six major areas of intentions are identified (Duany, A., Sorlein, S., \& Wright, W., 2008):

Quality of Life and Quality of Public Realm

The SmartCode and form-based codes intend to provide the tools to create good places to live by enabling smart-growth patterns and the creation of towns richer in experience similar to old towns such as Annapolis, Key West or Savannah.

\section{Code Structure, Clarity, Efficiency and Development Process}

The SmartCode and form-based codes intend to:

- Produce a unified development ordinance.

- Integrate subdivision and public works standards in addition to integrating architectural, landscape, signage and other zoning standards.

- Specify specific standards and parameters to minimize need for variances.

- Integrate protocols for preparation and processing of plans and encourages administrative approvals rather than approvals by public hearing.

- Increase the range of options compared to Euclidean codes. 
- Integrate planning at different scales form the region to the block and the building.

- Encourage "specific outcomes with both incentives and prohibitions," (p. 5).

- Create zoning categories common to both new and existing communities,

- Improve on the entitlement process.

- Integrate standards of different categories such as architecture, landscaping, signage thus making the code more efficient and easy to access.

- Envision "intentional outcomes based on known components of urban design" Menard (2009, para. 3).

\section{Neighborhood}

The SmartCode and form-based codes promote the concept of the neighborhood as a principal and comprehensive planning increment including effective provisions for the neighborhood. Neighborhoods create neighborhood urbanism as opposed to sprawl urbanism and, when clustered, produce cities and, when alone, they create a village.

\section{Walkability, Satisfaction of Daily Needs}

The use of traditional neighborhood design creates walkable neighborhoods that improve street safety based on Jane Jacob's eyes on the streets principle and generates "human habitat in all its complexity" (p. 4).

The SmartCode and form-based codes intend to bring activities of daily living into walking distance thus contributing to everyone's independence. 


\section{Community Strengthening}

The SmartCode and form-based codes intend to integrate economic classes and strengthen the bonds of the community with the mixture of housing types and uses.

\section{Sustainability}

The SmartCode and form-based codes promote a sustainable urban pattern. This is partly achieved by minimizing the number and length of automobile trips that reduces traffic congestion, road construction, and air pollution. Form-based codes intend to create places that serve both the natural environment and the people protecting ecologically and culturally valuable and sensitive habitats.

Transit

The SmartCode and form-based codes intend to provide appropriate building concentrations at easy walking distances from transit stops and makes transit a viable public option.

\subsubsection{Plater-Zyberk E. (2008)}

Plater-Zyberk E. discusses form-based codes in the introduction of Parolek, D., Parolek, K., \& Crawford, P. (2008) and four major areas of intentions are identified in her commentary (Plater-Zyberk E., 2008):

Quality of Life and Quality of Public Realm

Form-based codes intend to focus on the physical character and quality of a place, on walkability, implementing the policies of smart growth. 


\section{Specificity to Locality}

Form-based codes are guided by the principles of New Urbanism, Smart Growth, the transect and green building and are tailored to be place-specific.

\section{Community}

Form-based codes intend to create a holistic vision of community building and places of "dense economic and social interaction" (p. xii).

\section{Code Structure, Clarity, and Administrative Process}

Form-based codes have a rational structure that engages the public in the crease process with the intent to guide change predictably especially under the accelerating pressure for urban infill and "NIMBY-ism" (not in my backyard), (p. xii).

\section{Sustainability}

Form-based codes are touted as part of a new sustainable city-making approach, one that reduces automobile dependency.

\subsubsection{Polyzoides (2008 \& 2005)}

Polyzoides says that form-based codes aim at place-based planning, development and reform practice in the US and the world. Form-based codes, he argues, is the preferred 
instrument to implement New-Urbanism ideas to guide a locally specific future growth. Polyzoides singles out several principles guiding form-based codes that can be organized in the following categories:

Quality of Life and Quality of Public Realm

Polyzoides suggests that FBCs aim at creating settlements that thrive over time and overcome the chaotic, even cancerous, as he calls, impacts of modernist urban growth and sprawl:

"The process of coding operates fully within the American urban tradition of safeguarding the public realm while allowing significant freedom for the designers of individual buildings. It is in the balance of such public and private interests and concerns that the future quality of life in the American city lies." (Polyzoides and Moule, 2005, Coding section, para. 3)

\section{Specificity to Locality}

FBCs goal is place-based planning calibrated to the setting they apply, thus variable from place to place, particular to, and desirable to each community.

\section{Community Vision}

Form-based codes intend to implement and adhere to a community vision. At the same time they intend to be adjustable, so they can be revisited periodically with a changing community vision.

Code Structure, Clarity, and Administrative Process

Form-based codes intend to create a document that is: 
- Simply presented, highly illustrated, brief, and succinct so it is comprehensible.

- Integrated, addressing the public realm and five dimensions of urbanism, infrastructure, thoroughfares, buildings, space, and landscape design.

- Obligatory.

- Adjustable.

- Focused that clearly spells out changes and adjustments.

- Precise using specific dimensions for urban standards.

\section{Community Strengthening}

Form-based codes intend to be calibrated to the local economic opportunities bolstering the fiscal health of the community.

\section{Sustainability}

Form-based codes aim at sustainable development and practice sustainable urbanism.

\subsubsection{Emerson (2006)}

Emerson (2006) singles out traditional urbanism principles as the major intention in formbased codes. Single-use codes can pose an obstacle to such an endeavor. Anything resembling a traditional town in the form of Key West, Charleston, or Coral Gables would be impossible and illegal under prevailing codes. Strong urbanism is enabled with the incorporation of traditional urban planning and design principles that include neighborhoods, narrower streets and mixed use buildings. 
Quality of Life and Quality of Public Realm

Emerson quotes the Ahwahnee principles stating that "existing patterns of urban and suburban development seriously impair our quality of life" and form-based codes enable strong urbanism with incorporation of traditional urban planning and design principles (p. 646).

\section{Specificity to Locality}

Emerson says that a SmartCode is calibrated to the local character, needs of every community, and local and state laws and regulations.

\section{Code Structure, Clarity, and Administrative Process}

The SmartCode is easier to use because of its "strategic use of textual and graphic coding" that makes it "a highly intuitive tool" (Emerson, 2006, p. 667). The SmartCode brought an attempt to shorten the length of a zoning code and streamline administrative procedures, minimizing the need for variances and lengthy legal battles when attempting to sway from single-use zoning.

\section{Improvement over Euclidean Codes}

Form-based codes intend to create a unifying zoning and planning ordinance with provisions not usually included under conventional use-based Euclidean codes. Usually, within a jurisdiction, a zoning ordinance regulates land use while subdivision regulations, a separate document, regulates dimensional standards such as street widths and setbacks thus two continuously interacting documents are separate. The SmartCode combines 
the intentions of these two documents into a consolidated result. Other separate ordinance documents consolidated into a SmartCode are sign ordinances, noise ordinances, and landscape ordinances.

\section{Sustainability}

Form-based codes with the adoption of traditional planning techniques are a step in the right direction towards sustainable development patterns, and avoid an eventual point of crisis culminated under current use-based regulations.

\subsubsection{Parolek, Parolek \& Crawford (2008)}

Parolek, Parolek \& Crawford (2008) discuss form-based codes in their introduction identify four major areas of intentions:

\section{Quality of Life and Quality of Public Realm}

Form-based codes intend to improve the quality of the built environment in communities by achieving a specific urban form and adding vibrant centers with mixed uses to existing communities.

\section{Specificity to Locality}

Form-based codes intend to build on the unique characteristics of every place, creating a community with a unique sense of character. 


\section{Community Vision}

Form-based codes rely on a vision created by the community.

\section{Code Structure, Clarity, and Administrative Process}

Form-based codes intend to create easy to understand and administer codes with a streamlined approval process.

$\underline{\text { Sustainability }}$

Form-based codes intend to create more sustainable growth patterns by pursuing more interconnected compact development patterns that minimize sprawl and automobile trip distances and, as a result, transportation-related air pollution. The authors add that "because of the effectiveness Form-Based Codes have shown in facilitating smart growth, they are a powerful tool for achieving these goals of sustainable pattens of growth and development" (Parolek, Parolek \& Crawford, 2008 p. 5).

\section{Application of Urban Principles}

Form-based codes are based on spatial organizing principles that identify and reinforce an urban hierarchy. 


\subsection{Form-Based Code Intentions Conclusions \& Summary}

The above sources include intentions related to quality of life, place-specificity, community vision, code clarity and structure, and administrative processes. Other intentions mentioned are about sustainability, application of urban principles, community strengthening, satisfaction of daily needs, transit assistance, neighborhood creation, and walkability.

Overall, form-based code intentions can be summarized into two types: one addressing directly community and urban structure and a second type of intentions addressing qualities of the written code document. The following table presents the two types of formbased code intentions identified in the literature review:

\begin{tabular}{|l|l|}
\hline Table 1: Types of Form-Based Code Intentions \\
\hline $\begin{array}{l}\text { Community and Urban } \\
\text { Structure Intentions }\end{array}$ & $\begin{array}{l}\text { Code Document and } \\
\text { Development Process Intentions }\end{array}$ \\
\hline 1. Quality of Life & 4. Clarity of Zoning Documents \\
\hline 2. Specificity to Locality & 5. Efficient Development Process \\
\hline 3. Community Vision & $\begin{array}{l}\text { 6. Addressing other inefficien- } \\
\text { cies in Euclidean Codes }\end{array}$ \\
\hline
\end{tabular}

Intentions to improve quality of life are related to application of urban principles that benefit the public realm. One of these principles seems to be the concept of neighborhood especially emphasized by Duany, A., Sorlein, S., \& Wright, W. (2008). Sustainability, although an intention, seems to be the result of the application of the same urban principles about the neighborhood, blocks, streets, and building relation to the streets. Walkability and satisfaction of daily needs are also touted as important quality of life determinants. As 
a result, quality if life, achieved through application of specific urban design principles, can be stated as an umbrella concept in form-based codes incorporating and resulting in other aims, and will be further explored in Chapter 4.

Specificity to locality addresses the desire to adapt and tailor form-based codes to local conditions and is emphasized by most authors. Adapting the codes to local conditions includes adaptation to natural features, culture and architecture explored through site analysis and community input.

Site analysis is achieved through professional based analysis but community meetings and charrettes are instrumental in identifying local features. Natural features are used in understanding the structure of urban space, public open space creation, and neighborhood boundary delineation. Exploration and identification of local architectural features leads to zoning code standards that ensure the continuation of local tradition (Parolek, Parolek \& Crawford, 2008). Specificity to locality is often emphasized through pedestrian design and building character (The Chicago Metropolitan Agency for Planning, 2014). Culture includes local objectives and means of each community, goals for preservation or transformation, the local political landscape, and the financial and staff resources available to support the effort (The Chicago Metropolitan Agency for Planning, 2014).

Although Duany, A., Sorlein, S., \& Wright, W. (2008) do not emphasize specificity to locality and the SmartCode has been criticized for creating a cookie-cutter communities, Andres Duany refutes these arguments and declares the SmartCode as "locally calibrated" (Congress for New Urbanism, 2012, video position: 00:36:30). 
Community vision and participation is also a commonly referenced form-based code intention in the literature review, initiated from a desire to create a civic consensus similar to the consensus that guided traditional town development according to Talen (2009, p. 157). Polyzoides (2008) adds that this consensual community vision changes over time but form-based codes are adjustable so they can be revisited with a changing community attitudes. In form-based code planning, numerous community meetings and charrettes attempt to identify not only significant natural and architectural features but also important to the community issues and bring a form of a consensual vision for the city's future. Even Duany, A., Sorlein, S., \& Wright, W. (2008) that do not discuss community participation in the SmartCode, have used community input extensively in projects such as the Miami, Peoria, and St Lucie County form-based codes.

The form-based code intention to improve code structure, create clear and comprehensible codes, and an administrative process that is easy, efficient and predictable, represents another set of intentions with numerous aims that can be grouped under the title: Code Document and Development Process Intentions. Three stand out in the literature review:

- Creating clear and comprehensible zoning documents.

- Improving the efficiency of the development process.

- Addressing or fixing other inefficiencies of Euclidean Codes such as lack of predictability, multiple cross-referencing documents, numerous waivers, and numerous rezonings. 
Regarding the clarity of zoning documents, form-based codes intend to use both words and diagrams for clarity becoming highly illustrated documents. Although the legality of using diagrams was initially challenged, such a format is currently widely accepted. FBCs also attempt to create zoning documents that provide concise information by crafting zoning codes that are shorter, more concise and emphasize illustrations (Chicago Metropolitan Agency for Planning, 2014).

Polyzoides (2005 \& 2008) adds that form-based codes are documents simply presented, highly illustrated, brief and succinct. They are comprehensible, integrated, focused, clearly spelling out changes and adjustments, and precise with specific dimensions for urban standards.

Regarding the efficiency of the development process, FBCs are easy to understand and administer, have clearly defined and streamlined application, project review, and approval processes, and provide transparency and predictability in zoning and the zoning process (Parolek, Parolek \& Crawford, 2008, Talen, 2009, Chicago Metropolitan Agency for Planning, 2014, FBCI, 2014c). FBCs also integrate protocols for preparation and processing of plans and encourage administrative approvals rather than approvals by public hearing (Duany, A., Sorlein, S., \& Wright, W., 2008).

Form-based codes address a range of inefficiencies in Euclidean Codes such as lack of predictability, multiple cross-referencing documents with numerous waivers and rezonings. FBCs represent a comprehensive approach to zoning, combining many documents into one reducing cross-reference. The result is an integration of planning at different scales 
form the region to the block and the building and common zoning categories to both new and existing communities thus making the code more efficient and easy to access. As a result, form-based codes create what is referred to as a unified development ordinance integrating subdivision and public works standards in addition to integrating architectural, landscape, signage and other zoning standards.

FBCs regulate and not just advise and specify specific standards and parameters to make the built results predictable, minimize the need of variances, and increase the range of options compared to Euclidean codes. FBCs also encourage specific outcomes through both incentives and prohibitions and the code becomes predictable for both the community and the developers (Duany, A., Sorlein, S., \& Wright, W., 2008, FBCl, 2014).

Exploring all six intentions in the current document within the available time-frame of completing the graduate program in the City and Regional Planning Department at California Polytechnic University in San Luis Obispo, proved to be a time-prohibitive task. This document focuses on the first major form-based code intention, Quality of Life addressed in Chapter 4. 


\section{QUALITY OF LIFE INTENTIONS IN FORM-BASED CODES}

\subsection{Quality of Life Concept}

\subsubsection{Environment-Shapes-Behavior Theories}

In the exploration of urban form principles that shape quality of life, there is an inherent belief that the physical environment's shape and arrangement affect everyday behavior and lifestyle. Such a belief reflects views in Environmental and Behavioral Psychology, and Architectural Determinism. Environmental Psychology "examines the influence of the environment on human experiences, behavior and well-being" (Steg, Berg \& de Groot, 2013). The behavioral approach to psychology and behaviorism reflects beliefs that the environment causes humans to behave differently and that stimulus and clues from the environment affect human behavior (Psychologistworld.com, 2014). Architectural determinism on the other hand similarly asserts that human behavior is determined by the environment and as a result, the way a building or a city is laid out will affect people's behavior (Johnson, 1994, p. 293).

\subsubsection{Urban Environment and Quality of Life Principles}

\section{Definition of Urban Design Principles}

Principle is defined as "a fundamental, primary, or general law or truth from which others are derived" or "a fundamental doctrine or tenet" or "an adopted rule or method for application in action" ("principle," 2014). Consequently, an urban design principle attempts to be a general law or truth, a fundamental tenet to guide the design of cities. 
Urban design principles occur at various scales starting at the city-wide level to the detailed level of the street. The concept of neighborhood with a clear center and identifiable edge for example, is addressed at a city-wide scale while corner radii and street trees are addressed at the street level design.

\section{Urban Design and Urban Morphology}

The fields of urban morphology and urban design add to the exploration of urban principles, what works and what not when creating successful cities. Urban morphology "seeks to understand the spatial structure and character of an urban area by examining its patterns and the process of its development" (Planning.org, 2010). Urban Design "is about creating a vision for an area and then deploying the skills and resources to realize that vision" (Urban Design Compendium, 2014, p. 10) or, according to Urban Design (n.d.

para. 5), "Urban design involves the arrangement and design of buildings, public spaces, transport systems, services, and amenities. Urban design is the process of giving form, shape, and character to groups of buildings, to whole neighborhoods, and the city." Both fields have been working before or in parallel to the form-based code efforts. Mehaffy, Porta, Rofè \& Salingaros (2010) for example explore the difference between the concepts of neighborhood and the .25 mile pedestrian shed, two very important principles in FBCs.

\section{Community Vision and Urban Design Principles}

In the definition and intentions of form-based codes there is a belief in timeless urban design principles that contribute to a quality of life. What if the community's vision and desires however contrast to these principles? The possibility of a conflict between timeless principles and the community's desires, although plausible, is probably minimized by the 
fact that most communities adopting form-based codes, actively made the decision to pursue such codes. In reality the 'timeless' urban design principles in the form-based code definition reflect the desires of only a certain percentage of cities or people. As Andres Duany put it in the Center for New Urbanism 20th anniversary, "the SmartCode is only for those who want to live that way" and "there is a 30 to $60 \%$ that want what we don't like" referring to the suburbia versus New Urbanism lifestyle (Congress for New Urbanism, 2012, video position: 00:37:28 \& 00:58:02).

Still, questions arise about the relation of the principles brought to the community by planners and ideas expressed by the community. Although traditional urban design principles contribute to the quality of life there will always be a certain percentage that view quality of life in different terms. What is the nature of community input in relation to the 'timeless principles brought in by the designers and the planners? This is an open question for future investigation.

Despite such possible differences in input between community and designers and despite the fact that a certain percentage of the population may currently pursue a lifestyle seemingly different than the one offered by form-based codes, there is a set of principles that is strongly believed to contribute to the quality of urban life and represent the first intention of form-based codes.

\section{Quality of Life and Urban Design Principles}

The term quality of life is an umbrella term that includes all those assertions made by various authors on the impact of form-based codes to urban residents' everyday life. Claims 
of better quality of life in FBCs parallel ones made by the movements of New Urbanism and Smart Growth, source of form-based codes' principles. The urban design literature is also rife with quality of life statements.

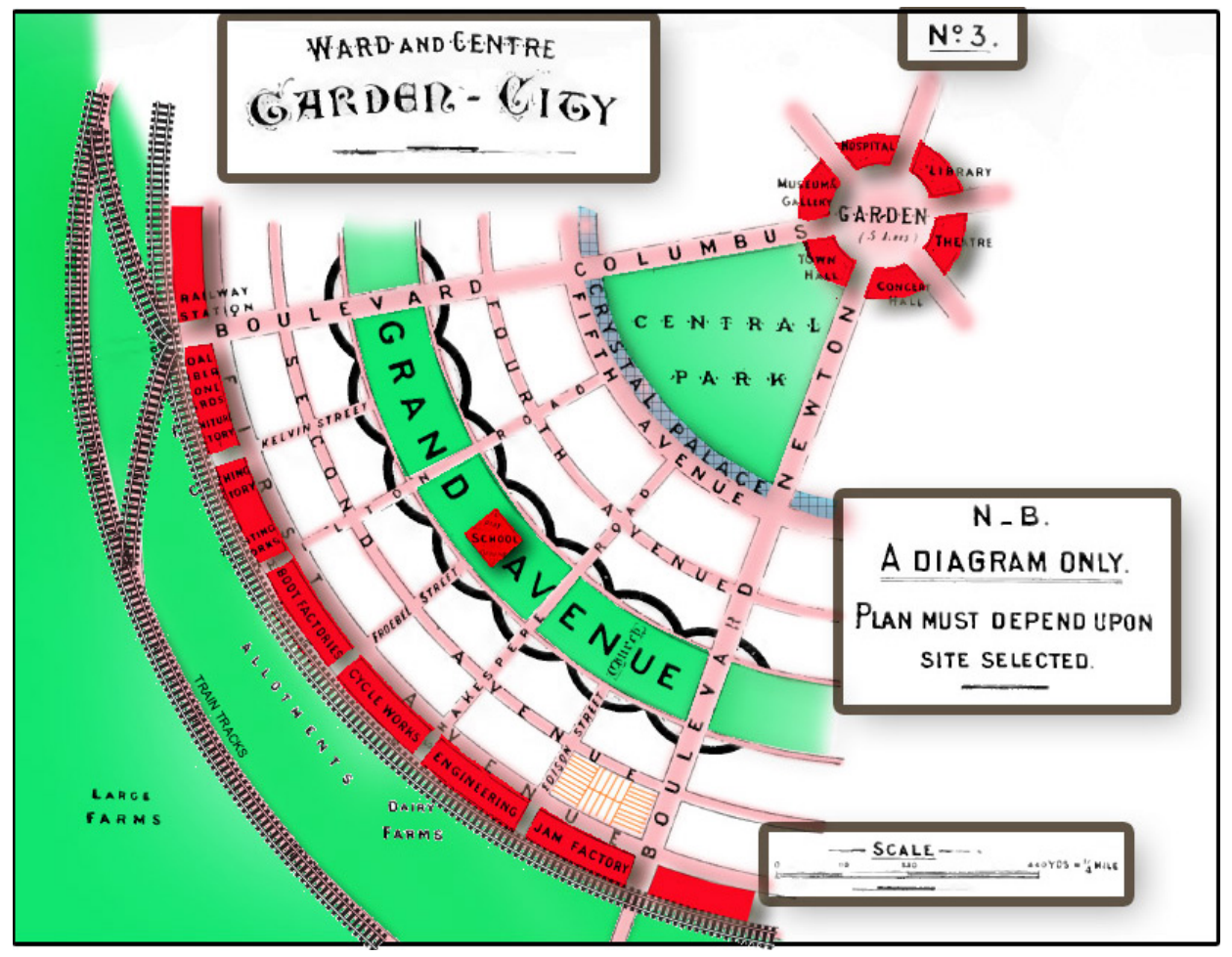

Figure 8: One of six sectors of Ebenezer Howard's Garden City in Howard \& Osborn (1965), with colors, train tracks and lot divisions in bottom right block added in the original black and white image for clarity. Adapted from Howard \& Osborn, 1965, pp. 22-23.

The code reform efforts of the past decades resulted in the use of urban design principles rooted in beginning of 20th century works, such as Ebenezer Howard's Garden Cities of Tomorrow in 1902 (Figure 8) and the Neighborhood Unit concept by Clarence Perry (1929), (Figure 9).

Zoning codes in the 20th century left considerations of urban form to architects and designers, but code reformers, including those in form-based code efforts, attempt to incor- 
porate urban design principles in zoning codes, achieve quality of urban form, and contribute to a better sense of place (Talen, 2009, p. 158).

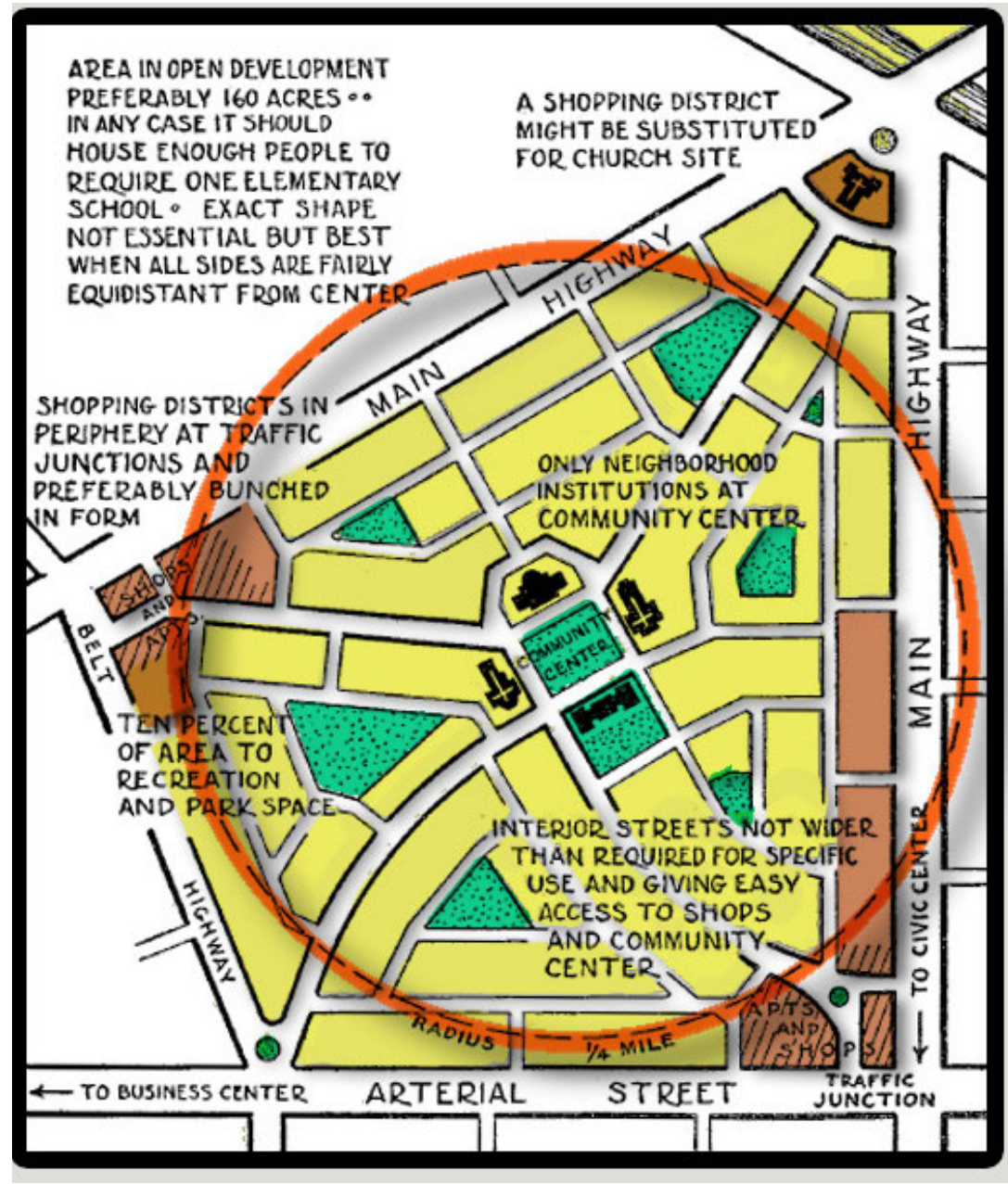

Figure 9: Clarence Perry's Neighborhood concept. Adapted from Mehaffy, Porta \& Romice, 2014, p. 2.

Camillo Sitte in his influential publication of 1889, "City Planning according to Artistic Principles" advocated for a better city and he recommended public squares as a major element in every city creating a backdrop to daily life and a place to observe the great buildings of the city. 
Ebenezer Howard (1902) was the first to introduce the concept of neighborhood and the ideal city of $2 / 3$ of a mile radius with many open spaces and parks (Figure 8 ). He called it the Garden City and intended to marry the benefits of both country and city into one urban system.

Clarence Perry (1929), was the first to introduce the idea of the neighborhood as a quarter mile pedestrian shed, about the population needed for an elementary school (Figure 9). His neighborhood unit was extremely influential in the later development of New Urbanism and Smart Growth movements. Coincidentally, the concept of neighborhood also influenced modern planning and suburban sprawl by creating neighborhoods focused on the automobile, based on the elementary school concept but separated by huge arterials.

Since the Assyrians, the Greeks, and the Romans, to the relatively recent Spanish Laws of the Indies, rules about creating a better city were often established (Talen, 2009). Although not directly aimed at enhancing the city's quality of life, all seemed intended to create a better city plan.

In most of these attempts the plaza or central square stands prominent. Clarence Perry and Ebenezer Howard introduced a self-sufficient entity with clear boundaries revolving around a central plaza. This concept of a neighborhood with a clear center and identifiable boundaries was to become a very influential concept in Form-Based Codes. 


\subsection{Quality of Life Principles in Form-Based Code Theory}

The link between urban quality and physical layout is stated directly in the official $\mathrm{FBCl}$ website by saying form-based codes intend to create a high quality public realm with the use of physical form (Form-Based Codes Institute, 2014c).

Much of the form-based code movement, with roots in new urbanism, recognizes the traditional American town layout with short blocks, central square, centrally located public buildings, identifiable urban boundaries, and narrow streets, as a better place to live than a suburban urban layout.

Duany, A., Sorlein, S., \& Wright, W. (2008), state that the SmartCode promotes a sustainable urban pattern and provides tools to create good places to live. The handbook by the Chicago Metropolitan Agency for Planning (2014), an effort "to make Chicago a better place to live" (p. 5), introduces form-based codes as part of the attempt to create livable communities that are walkable, offer transportation choices with timely access to services, and basic needs, and "are imbued with strength and vitality..." (p. 5). The Local Government Commission (2014), in the preamble to the Ahwahnee Principles, says that quality of life in urban and suburban developments refers to an aspiration to create communities "that will more successfully serve the needs of those who live and work within them."

Plater-Zyberk E. (2008), stated that FBCs focus on the physical character and quality of a place (p. ix) while Parolek, D., Parolek, K., \& Crawford, P. (2008, p. 12) say that form- 
based codes intend to improve the quality of built environment and intend to achieve a specific urban form as form-based codes regulate the details that are most important for the successful implementation of walkable, human-scaled neighborhoods, focusing primarily on urban form, while also addressing use and other necessary factors:

The quality of most recently built civic spaces is extremely low because current regulations primarily regulate the amount of civic space required with few standards pertaining to the quality of the space. ... The character of the parks, plazas, other open spaces, and public thoroughfares, including the features within thoroughfare right-of-ways (ROWs), profoundly affect the quality of an urban place. For this reason, Public Space Standards that address these features are an essential component of a Form-Based Code (p. 35).

Finally, the Form-Based Code Institute (2014) says that form based codes aim at producing "walkable, identifiable neighborhoods that provide for daily needs" and "invite social interaction." The walkable, identifiable neighborhoods that provide for daily needs set a group of three basic principles that define the urban form principles that shape quality of life in form-based codes.

\subsubsection{Seaside, and TND Developments}

Parolek, D., Parolek, K., \& Crawford, P. (2008) claim that, the urban design components of form-based codes focus on the basic tenets of New Urbanism and Smart Growth movements (pp. 12-13) and Gowdy (2009) confirms that form-based code urban design principles have their root in the New Urbanism movement.

The code in Seaside, FL (Figure 10), a precursor to the New Urbanism and Smart Growth movements, is considered the first form-based code developed in 1986. It includes stan- 
dards for yard, porch, balcony, outbuilding, parking, and building height allocating specifications for street, block, lot and public space layout to the master plan created by the project architects (Salden, 2014a). Traditional Neighborhood Design developments and the Ahwahnee Principles by the Local Planning Commission followed in the late 80's and early 90's clearing the way for the Congress for New Urbanism Principles.

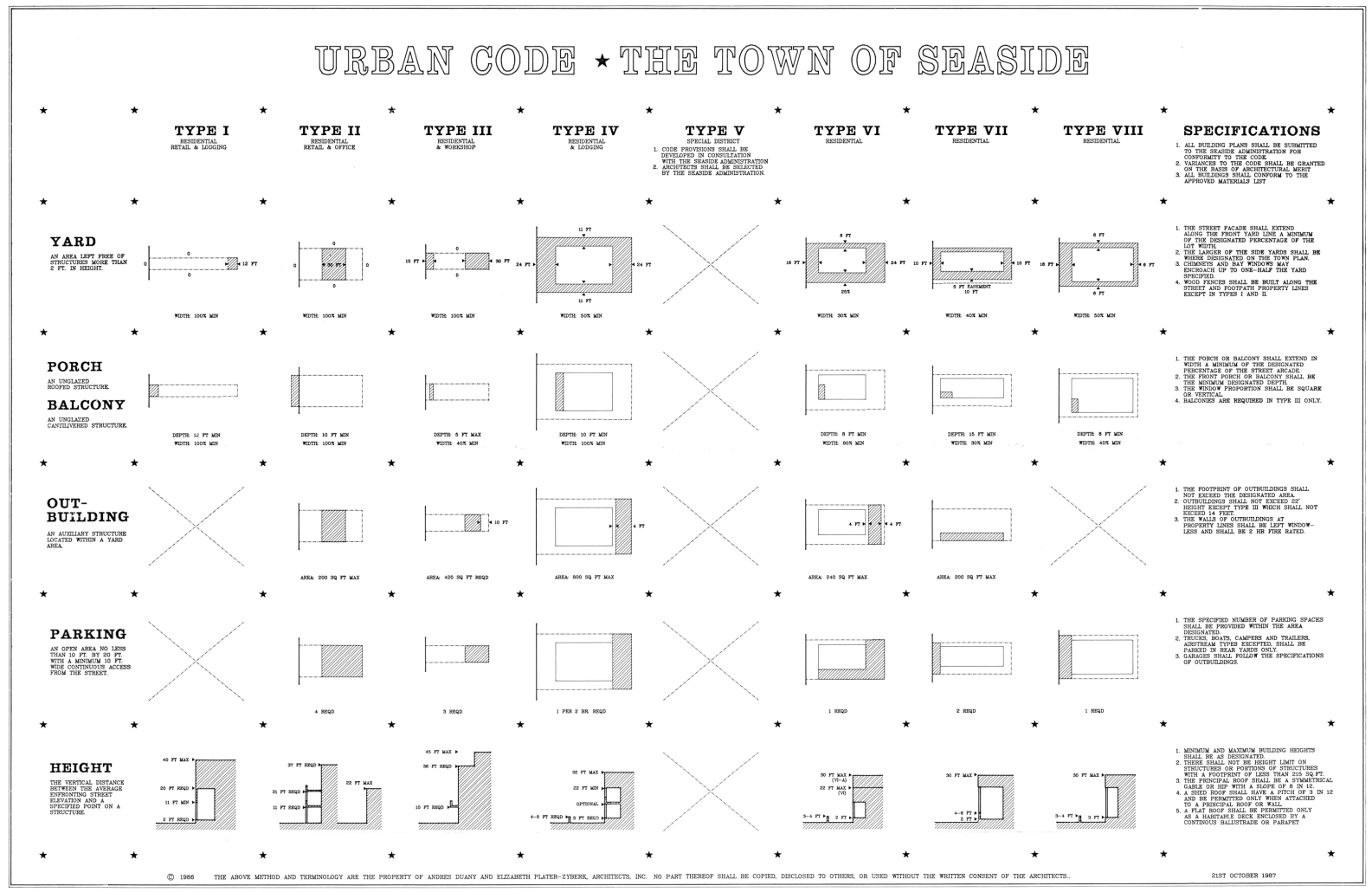

Figure 10: The first form-based Code in Seaside, FL. From The Seaside Code by Salden, 2014a.

The Seaside Code aimed at a variation of types of buildings and the belief that "buildings would have to grow and evolve over time with input from a variety of clients and designers" (Salden, 2014a). Eight types of buildings are allowed based on location within the town. Each type is regulated for yard, porch, balcony, outbuilding, parking, and building height. Figure 11 shows Type I lots which include their own regulations and outline the central square. 
Building variation according to location seems to be the basic principle incorporated into the spartan Seaside zoning code which controls the implementation of the urban design plan. The design plan (see Figure 12) intended to emulate traditional Southern towns and settlement patterns (Duany Plater-Zyberk \& Company, 2014). "The town is laid out so that most of life's daily needs are available within a short walk or bike ride" and all public spaces link to the town center (Seaside Institute, 2014b). Many shops and services are within or adjacent the downtown area.

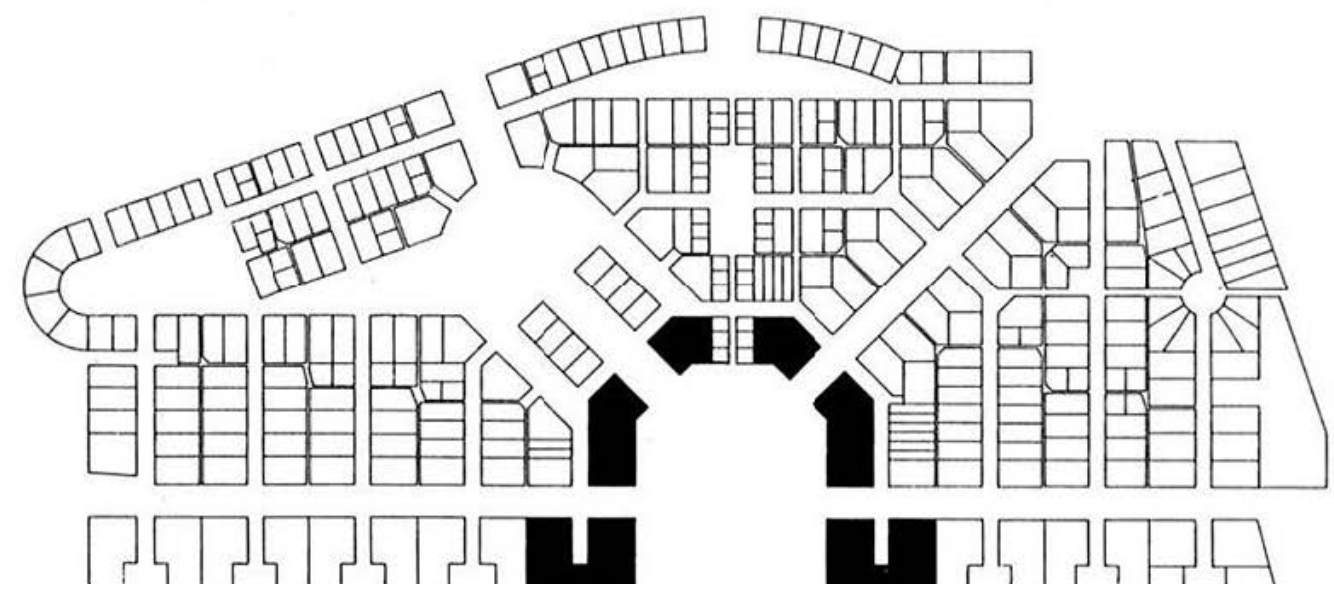

Figure 11: A set of buildings (transect) assigned separate standards around the central plaza in Seaside, FL. From The Seaside Code by Salden, 2014a.

Adjacency is a basic principle that is repeated in the Neo-Traditional Developments (TNDs) that followed Seaside's example. Such neighborhoods offer within walking distance of private homes, "a variety of housing types and land uses in a defined area ...creating a balanced community that serves a wide range of home and business owners" (Town Paper, 2014). Pedestrian friendly means that "a TND is served by a network of paths, streets and lanes suitable for pedestrians as well as vehicles, bicycles and transit. This provides residents the option of walking, biking or driving to places within their neighborhood. Present 
and future modes of transit are also considered during the planning stages. In addition, inclusion of community spaces such as plazas, greens or parks and civic buildings contribute to the community identity and value.

The form-based code in Seaside, is part of a master plan crated by Duany Plater-Zyberk \& Company. Another form-based code by the same company is the Birmingham, MI Downtown Master Plan of 1996 (City of Birmingham, MI, 2014). In both Seaside, FL and Birmingham, MI, urban design principles addressing city layout are part of a master plan complemented by a form-based code ensuring the plan's implementation.

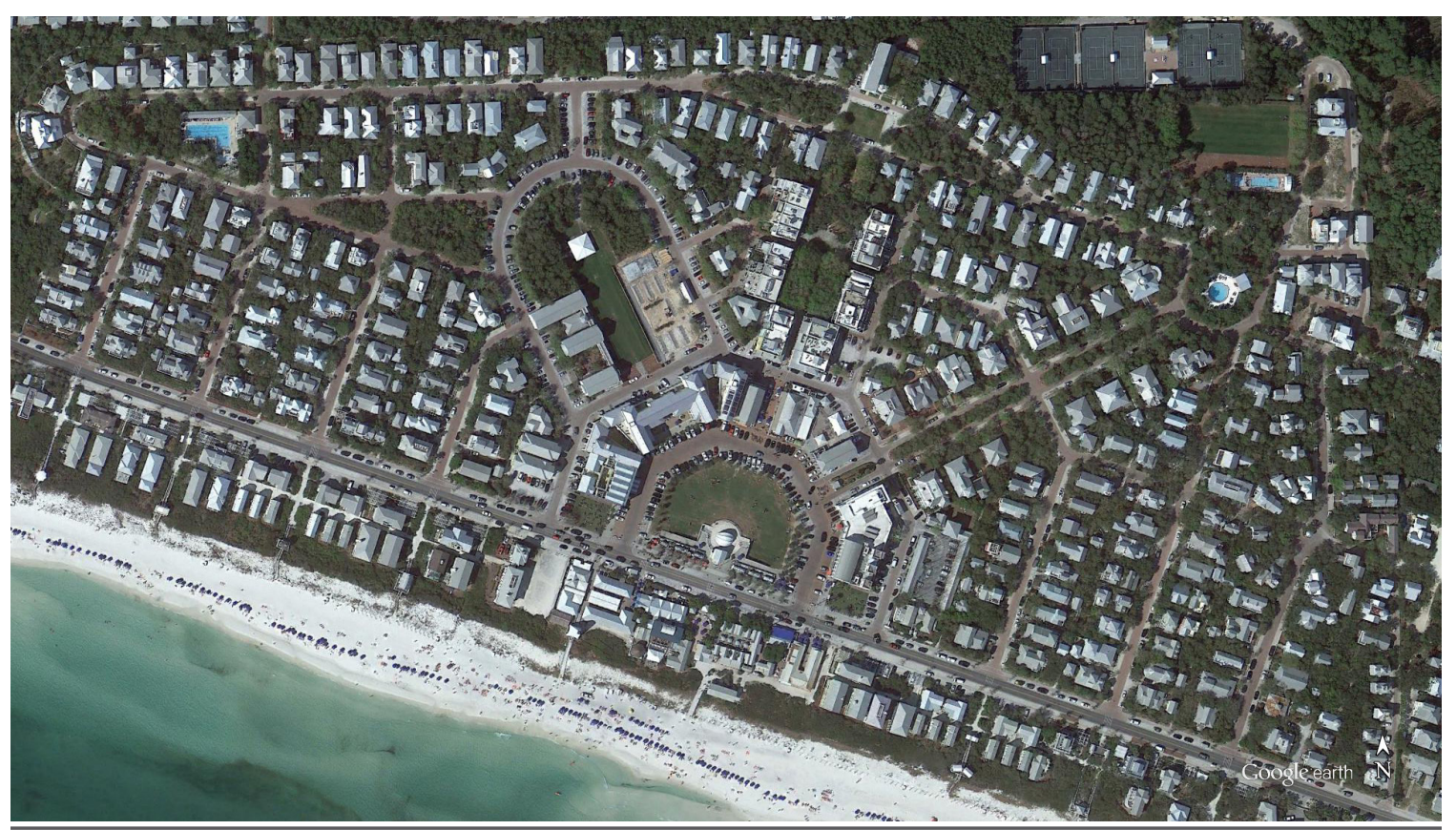

Figure 12: Aerial photo of Seaside, FL (Google Earth Image).

The urban form principles present in the Seaside Plan, the Seaside Code and TNDs have one overarching characteristic, the desire to create walkable neighborhoods that address daily residents' needs. This was typical of American towns built before the advent of the automobile and is present in the Ahwahnee and New Urbanism principles as well. Three parameters stand out: 
- The concept of neighborhood,

- Proximity to daily needs.

- Walkability (and the .25 mile radius)

\subsubsection{Ahwahnee Principles}

New Urbanism according to Mehaffy (2014) was born in 1991 at a conference at the Ahwahnee Lodge in Yosemite, California initiated by the Local Government Commission in Sacramento. At the conference, a group of architects came together to agree on a set of community and regional principles to guide quality urban development. The authors were Peter Calthorpe, Michael Corbett, Andres Duany, Elizabeth Moule, Elizabeth Plater-Zyberk and Stefanos Polyzoides, with editors: Peter Katz, Judy Corbett and Steve Weissman.

The effort was a reaction to the negative effects of sprawl and other perceived unfavorable conditions of urban environments. According to the Local Government Commission (2014), existing patterns of urban and suburban development seriously impair our quality of life. Symptoms listed are traffic congestion and air pollution resulting from our increased dependence on automobiles, the loss of precious open space, the need for costly improvements to roads and public services, the inequitable distribution of economic resources, and loss of sense of community.

The Ahwahnee principles, address region and communities alike, and aim at communities with diverse uses covering the essential daily needs of the residents within walking distance. 
Regional principles emphasize preservation of open space between regions and communities to create a well-defined green edge devoid of development, and preservation of natural features. A center or urban core with concentrated civic and public uses is important for communities along with distributed open spaces. A strong inter-regional transportation network and use of local materials is also encouraged.

Community principles define an integrated community when services, shops and civic facilities, essential to daily life of residents, are within walking distance of residents' homes and transit stops. Community principles emphasize preservation of resources, energy efficiency and water conservation. Essential are diverse building types for a variety of uses, an efficient transit network, and walkable and bike-able street networks that encourage transportation options. Walkability is reinforced when high speed traffic is discouraged, and when buildings, trees and lighting spatially define streets.

\subsubsection{Congress for New Urbanism Principles}

The Ahwahnee principles set the base for the New Urbanism Principles published by the Center for New Urbanism (CNU). CNU separated guiding principles by scale starting with the Region, Metropolis, City, and Town, then Neighborhood, District, and Corridor, and finally, block, street, and building.

Urban form features emphasized, are: Identifiable edges in and between neighborhoods, towns and regions, neighborhoods with centers, civic and institutional building location around the center or prominent locations, compactness of neighborhoods, walkability, in- 
ter-connected streets, variety of building types and uses, physical definition of streets, and transportation options.

A 2010 publication of the Michigan Chapter of the Congress for New Urbanism (CNU, 2010) adds a few more urban form principles: small blocks, a gradual decrease in concentration of housing from center to edge, pedestrian friendly streets throughout the community, walkable neighborhoods, ability of children to walk to schools and to recreational facilities, buildings close to the street, streets used for parking, vehicles, pedestrians and bicycles, and prominent sites such as termination of vistas reserved for civic buildings and monuments.

\subsubsection{Smart Growth Principles}

Simultaneously with New Urbanism, in the mid-90's, the concept of Smart Growth appeared as part of the Environmental Protection Agency's effort to promote compact landuse patterns. Ideas in the Smart Growth movement were influenced by Peter Calthorpe and Peter Katz who had already participated in the Ahwahnee conference and the establishment of the Center for New Urbanism (Goetz, 2004).

Smart Growth principles relative to urban form are: walkable neighborhoods, variety of transportation choices, mix of land uses, range of housing opportunities, compact building design, distinctive and attractive communities with a strong sense of place, and preservation of open space, farmland and critical environmental areas (Environmental Protection Agency (EPA), 2014) 
Although the Smart Growth Principles do not directly mention proximity to daily needs and centers, EPA's Smart Growth web pages discuss centers and proximity to daily needs. On centers, they recommend to designate locations for higher density development centers in comprehensive plans and that new town centers provide transportation choices, improve quality of life, create affordable environments for people of variety of incomes, opportunities for social interaction and cost-effective infrastructure and services.

On proximity to daily needs, the Smart Growth website introduces the concept of location-efficient siting of buildings, that advocates creating proximity between residential development and stores, restaurants, and public transit thus increasing the number of transportation choices, facilitating walking and other modes of transportation, and reduces infrastructure costs and overall the environmental impact of development.

\subsubsection{Summary of Form-based Code Principles Contributing to Quality of Life}

Code Reformers in the Smart Growth and New Urbanism movements aimed at addressing the major issues resulting from sprawl, such as unsustainable and inefficient urban growth patterns that generate huge land consumption and excess traffic. Form-based codes improve quality of life by aspiring to a city where neighborhood units are valued, have a prominent center, identifiable edge, are walkable to uses satisfying daily needs, and offer a variety of transportation options. 
In summary, the major urban form related principles addressing quality of life could be summarized under the umbrella of the following three, inclusive enough to incorporate several other urban principles:

1. The city is composed of neighborhood units with a prominent center and identifiable edge.

2. The proximity and variety of uses within neighborhoods enables fulfillment of residents' daily needs.

3. Neighborhoods are walkable with transportation options available.

These principles permeate the form-based code process, appear in all stages, at different scales of design and are satisfied by different sub-principles in every stage. All three affect pattern (2-dimensional layout of streets and blocks), form (3-dimensional layout of buildings), and use (use is affected by form of buildings), the three ways zoning affects the land according to Talen (2012). 


\subsection{Neighborhood Principle}

\subsubsection{Neighborhood definition and history}

The concept of neighborhood "is a model of urbanism that is limited in area and structured around a defined center. While the population density may vary, depending on its context, each model offers a balanced mix of dwellings, workplaces, shops, civic buildings and parks" (Parolek, D., Parolek, K., \& Crawford, P., 2008 p. 112). The authors also state that form-based codes should reinforce this neighborhood structure as a vital aspect of "any good urban place" (Parolek, D., Parolek, K., \& Crawford, P., 2008 p. 112). Such a good neighborhood structure has a clearly defined center, an edge, a mix of housing types and activities, prominent locations of civic and public buildings, and a network of integrated streets. Figure 13 shows the concept of neighborhood with a center as applied to Brisbane, Australia to understand the city's urban structure.

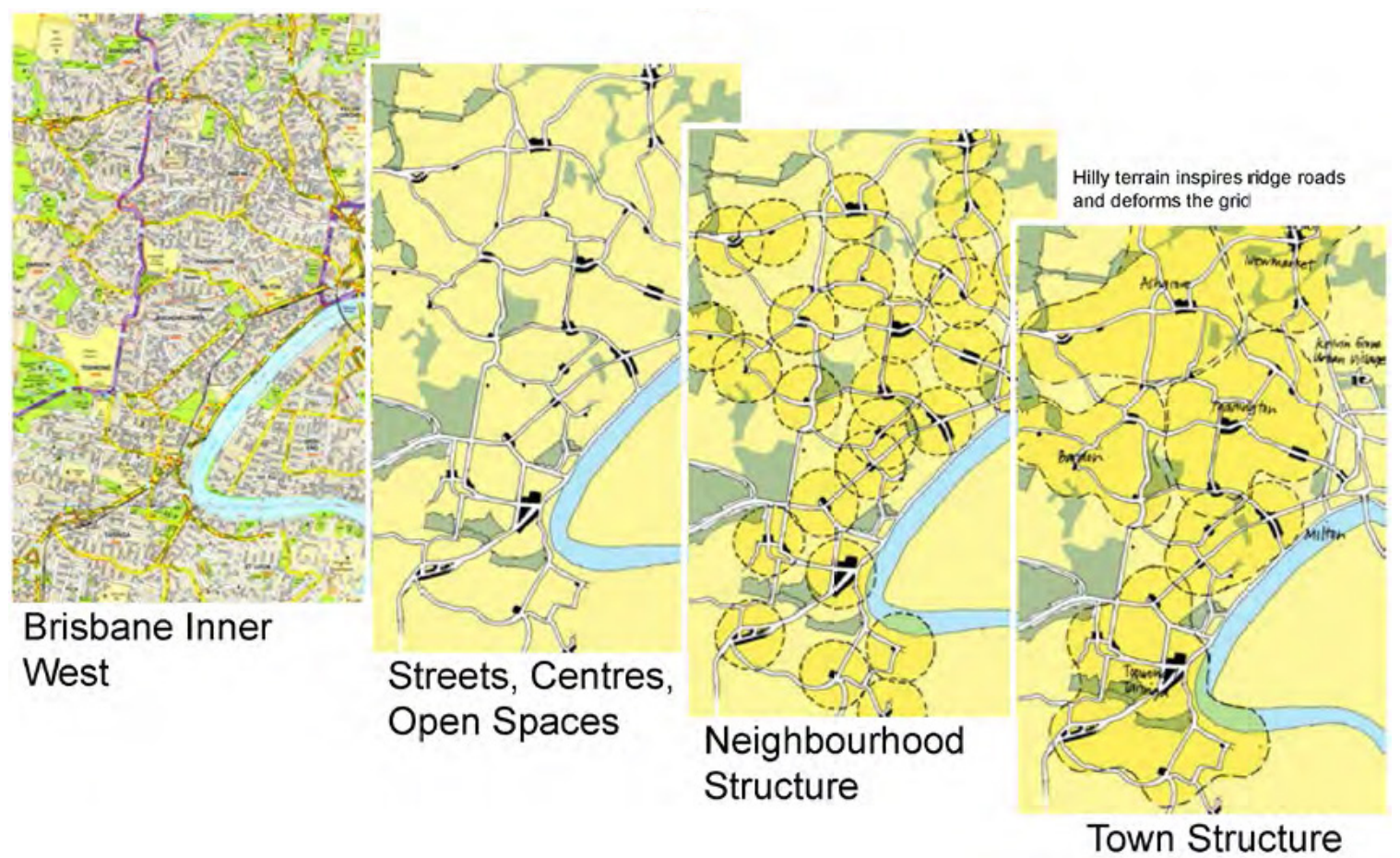

Figure 13: Applying the neighborhood principle to understand urban structure in Brisbane, Australia. Adapted from Optimizing Urban Structure: Towards an Integrated New Urbanist Model by Jones, 2009, p. 9. 
According to Chen (2008) who did a review of the concept of neighborhood in recent urban design history, Ebenezer Howard was the first to initiate concept in his seminal 'Garden Cities of Tomorrow.' Lewis Mumford in the introduction of the same book, attributes Howard's influences to the fledgling American towns of the 1800's Howard had visited in the middle of the 19th century. Howard contained his city in a .75 mile radius around a civic center and his intention was to combine the best of country and town into a new city form he called a garden city.

Later on, in 1929, Clarence Perry expanded the idea of neighborhood and originated the .25 mile pedestrian shed (approximately 400 yards or 400 meters). Perry defines a neighborhood unit as a spatial entity with a center inside a .25 mile radius. Building types ranged from residential, to commercial and civic. Perry also emphasizes the importance of a clear and identifiable edge in neighborhoods as helping to create "a distinct entity in public consciousness."

The concept of a well-defined neighborhood brings to mind Kevin Lynch's (1961) concepts of districts in his seminal 'Image of the City' where districts represent a similar concept to neighborhoods. In Lynch's districts, the requirement for good definition includes the use of streets, natural features, open land, or parks as a means to shape the edges of a neighborhood or a community and often adjust road and block layout to local patterns. Two decades later however, Kevin Lynch (1984, p. 246) declared the neighborhood as "the basic building block of a city" and initiated the concept of cellular model in urban planning (Kevin Lynch 1984, p. 400). The cellular model conceives the city as an aggregate of area 
units or cells such as neighborhoods (see Figure 14). The model is modular consisting of multiple neighborhoods each with a center and edge.

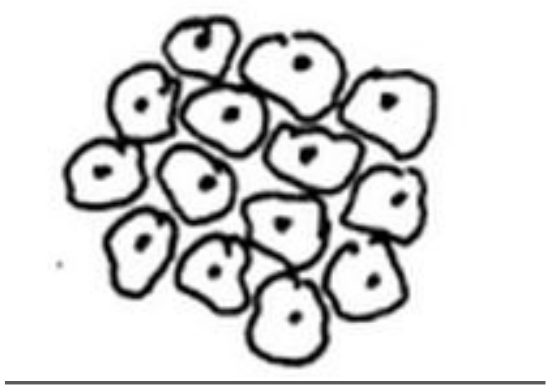

Figure 14: Cells or else urban units making up a city according to Kevin Lynch's cellular model. From City Form by Lynch, 1984, p. 400.

Chen (2008) says this cellular model has been applied frequently in residential development during the past century. However, although many subdivision developments are based on a neighborhood approach they lack walkability and often centers or edges and conceive the neighborhood concept as mostly population-related capable of supporting an elementary school per Clarence Perry's (1929) ideas.

\subsubsection{Neighborhood and Coding Areas}

The concept of neighborhood represents the fundamental difference between use-based codes and form-based codes. Use-based codes separate the city into single use areas while FBCs separate the city into a set of neighborhood units each subdivided into urban intensity areas, often called transects, with denser transects in neighborhood centers. Urban intensity areas are the coding areas. Besides urban intensity areas, corridors, building types or facades are also used as coding areas within a neighborhood unit. However, even then, neighborhood centers and edges are fundamental in the location of coding ar- 
eas. Corridors are edge elements that can separate, connect, and outline a neighborhood or comprise part of the neighborhood center.

A yardstick for neighborhood size is the .25 mile walking radius defining a neighborhood spatially and assisting form-based planning in the initial breakdown of urban areas into neighborhoods. This quarter mile radius is the one mostly used, since it relates to the distance humans are willing to walk before changing to a faster transportation medium. Radii of .5 or .75 miles are also used periodically.

\subsubsection{Social Dimension of Neighborhoods}

What sets the cellular model of cities and the concept of neighborhoods apart from all other models in Lynch's (1984) narrative, is that the idea of neighborhoods is supported by sociological explorations of city structure and is valid in people's minds when relating to the area around their residence. Therefore the spatial component of neighborhoods is validated by its social component and possible vice versa since the arrangement for the built environment can affect social perceptions of neighborhoods. But since the social component is more difficult to quantify, the .25 mile pedestrian shed radius becomes an important tool in structuring urban environments.

Both Chen (2008) and Mehaffy, Porta, Rofè \& Salingaros (2010) separate the spatial and social characteristics of neighborhoods. Kruger (2007, p. 53), however, verifies the social importance of the .25 mile radius in residents' perceptions of measures such as "social contact with neighbors, perceptions of social capital, fear of neighborhood crime, and satisfaction with neighborhood quality of life." 
The social and spatial aspects of Neighborhoods are often not distinguished in formbased code practice. Instead the focus is on the .25 mile radius and the spatial attributes of a neighborhood.

\subsubsection{The .25 mile Walking Radius}

The .25 mile walking radius is, according to Mehaffy, Porta, Rofè \& Salingaros (2010), a well investigated measure of neighborhood size remaining constant among urban cultures throughout history that defines the approximate area enclosed between major streets. The authors add that:

This rule has to do with several universal characteristics of the human body in relation to the environment, and correctly balances the need to navigate urban space effectively on foot, with the competing need to maximize the use of space for developing buildings and activities at a proper density. (p. 33)

According to Chen (2008) the .25 mile radius, first proposed by Perry in 1929, represents a 5 minute average walkable distance a pedestrian is willing to walk before a change in transportation option is desired.

Chen (2008) mentions that the distance a pedestrian is willing to walk varies among urbanists and Katz (1994), for example, mentions 10 minutes, or a .5 mile walk. Such a distance is utilized to delineate some neighborhoods in the recent form-based Tehachapi, CA General Plan (Tehachapi General Plan, 2012).

Despite such aberrations, the .25 mile radius is a generally accepted measure of desired walkability based on the 3 mile per hour average human walking speed: 
The unit of measurement is commonplace in the planning profession and is often represented by a radius measuring $1 / 4$ of a mile. The average walking speed of a human is at approximately 3 miles per hour, which translates to $1 / 4$ of a mile in five minutes. Most planners, admittedly including myself, often represent the walking distance on a proposed plan drawing or an aerial as a circle drawn with the center of the circle on the destination. The circle is most often represented as 1320 -feet radius. (Olson, 2013, para. 1)

The .25 mile radius includes a population and an area measure. The population size often relates to the number of people needed to supply an elementary school, about 1000 to 1500 families according to Perry (1929), while Calthorpe in Kelbaugh (1989) mentions 160 acres. Often population density determines whether a .25 or .5 mile radius will be used. In the Tehachapi General Plan (2012) .5 mile radii were used in lower density areas.

Mehaffy, Porta, Rofè \& Salingaros (2010) comment that the only time in human history cities attempted to divorce themselves from this rule was during modernism when the quarter mile rule was tied to population size needed for an elementary school instead to walkability. The result was large pedestrian unfriendly arterials separating neighborhoods. In essence, Mehaffy, Porta, Rofè \& Salingaros, criticize the modernist distortion of Ebenezer Howard's concept that severed the .25 radius from walkability and sliced the city fabric with big arterials. With the advent of New Urbanism and Smart Growth the concept of neighborhood is tied again not only to the cellular model proposed by Lynch but also to walkability and walkable proximity to daily needs.

The social dimension of neighborhoods relates to the .25 mile radius, but in urban morphology literature, Mehaffy, Porta, Rofè \& Salingaros (2010) consider the social dimension useless to urban designers. The authors consider neighborhoods transient, complex 
and non-fixed socio-cultural entities better left to social forces to shape and locate. Instead, the authors recognize only the spatial characteristic of neighborhoods as useful to designers and instead consider the pedestrian shed of .25 mile radius as more important in shaping cities.

Mehaffy, Porta, Rofè \& Salingaros (2010) advocate a module of four .25 mile neighborhood areas meeting at a walkable intersection of two major arterials. They propose a model consisting of a pedestrian shed with a nucleus at the walkable intersection of two major streets creating four areas behind each corner labeled 'sanctuary' areas where neighborhoods in the social context can form freely as minor, ephemeral centers (see Figures 15,16, and 17).

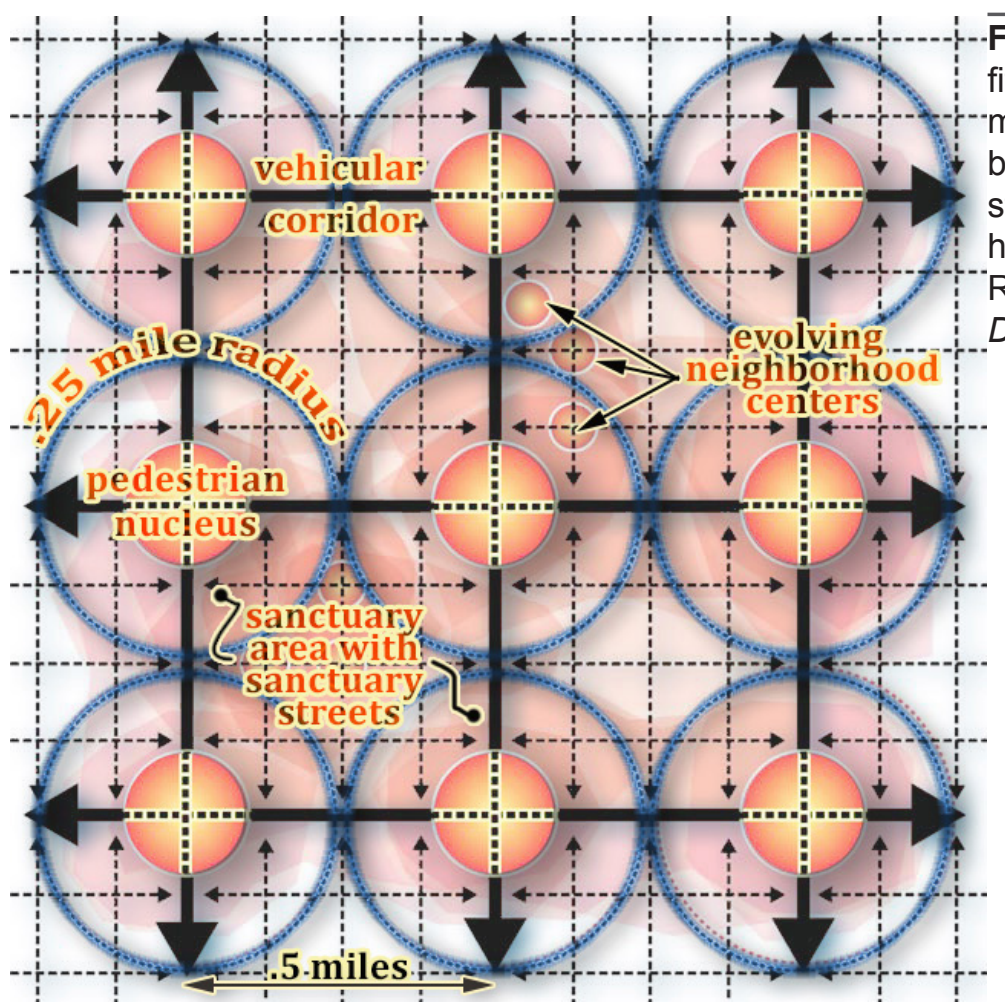
Figure 15: Urban model of best fitting pedestrian sheds and commercial nuclei. Adapted from "Urban nuclei and the geometry of streets: The 'emergent neighborhoods' model" by Mehaffy, Porta, Rofè \& Salingaros, 2010, Urban Design International, 15(1), p. 31. 


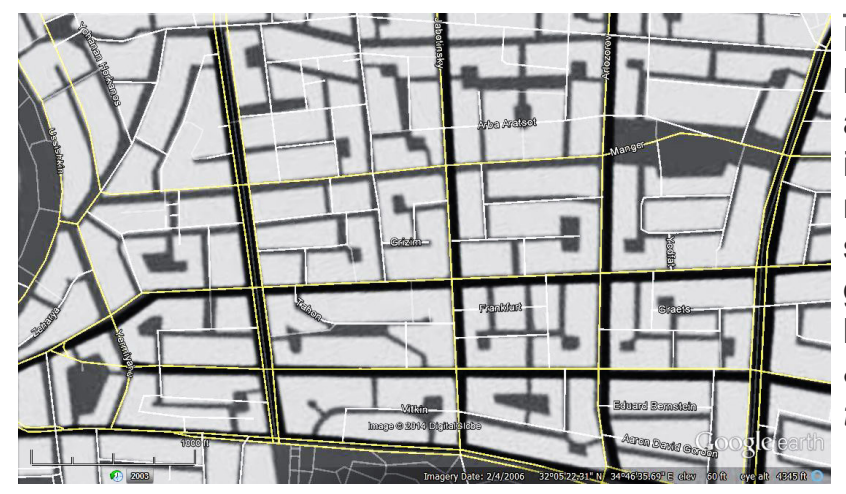

Figure 16: Urban plan of Tel Aviv, Israel by Scottish architect Patrick Geddes that according to Mehaffy, Porta, Rofè \& Salingaros (2010) exemplifies the proposed model of urban nuclei with pedestrian sheds. Adapted from "Urban nuclei and the geometry of streets: The 'emergent neighborhoods' model" by Mehaffy, Porta, Rofè \& Salingaros, 2010, Urban Design International, 15(1), p. 42.

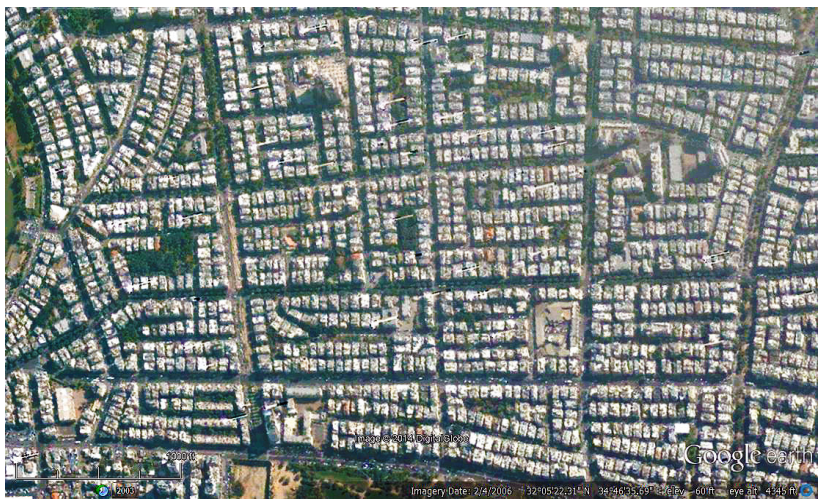

Figure 17: 2014 aerial photo of same as above section of Tel Aviv, Israel showing the closely adopted Geddes plan (Google Earth image).

\subsubsection{Neighborhood Parameters In Form-Based Codes}

Three spatial principles that shape neighborhoods stand out from the literature review:

- Center,

- Edge and

$\cdot .25$ mile radius.

The presence of these three parameters can be easily explored in a form-based code. The .25 mile pedestrian shed will affect street structure and placement of neighborhood centers in relation to the surrounding areas, therefore the .25 mile radius affects all three of Talen's (2012) zoning impacts on land (Figure 2), pattern, form, and use. Most importantly, the .25 mile pedestrian shed defines the spatial extent of a neighborhood unit that is used to break an urban area into smaller parts. 


\subsection{Proximity to Dally Needs Principle}

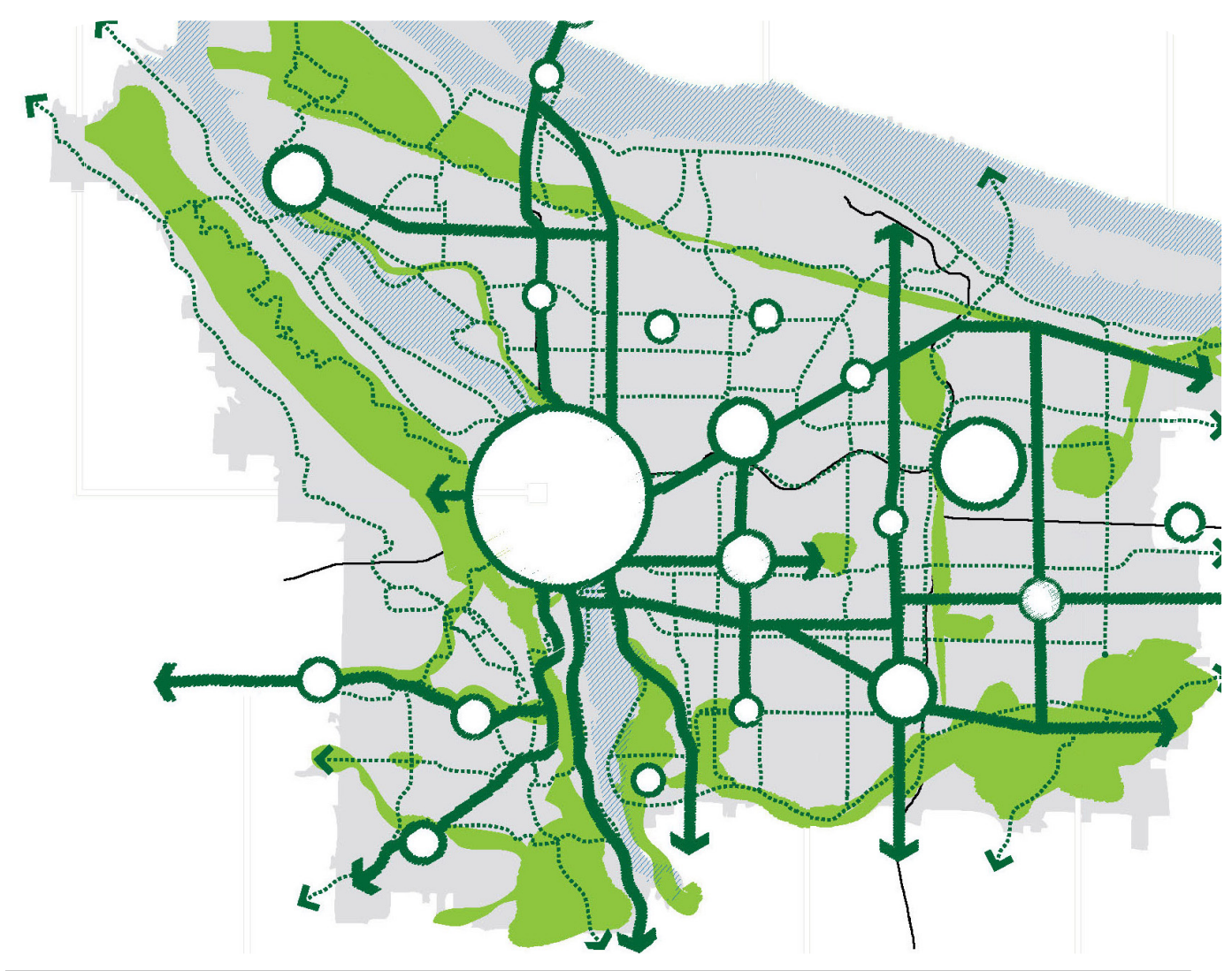

Figure 18: Portland, OR with proposed neighborhood centers and '20 minute neighborhoods. From City of Portland, \& Portland Bureau of Planning and Sustainability (BPS), 2014.

\subsubsection{Definition}

One of the symptoms of sprawl is the long distances someone has to travel or commute to satisfy daily routines such as going to work, shopping at the local market, buying bread, getting a cup of coffee with a friend, getting a haircut, going to the bank, and so on. Even if destinations are close, the spatial arrangement of subdivisions and the lack of direct connections to shopping or office areas makes the choice of transportation mode other than the car impractical. 
One of the means of improving the quality of life in urban environments is to create walkable proximity ( .25 mile radius neighborhoods) to shopping and office complexes so that commuting and shopping trip time is minimized as much as possible. Such a solution provides the option to walk, bicycle, use the transit, or use the automobile and provides conveniences by including a diverse mix of uses within a central location. Some cities are catching up to this idea and Portland, OR (See Figure 18) has set the objective to have $90 \%$ of Portland residents "easily walk or bicycle to meet all basic daily, non-work needs" by 2030 (City of Portland, 2014).

Many authors discuss the importance of neighborhoods satisfying residents' daily needs. One of the first to introduce the concept of a self-sufficient community with civic buildings in the center and shopping areas in a periphery was Ebenezer Howard in his book Garden Cities of Tomorrow in the late 1880's. Howard identifies the ideal city with a population of 32,000 or between 1200 and 1500 family units and an identifiable center and edge, very typical of New Urbanist ideas (Chen, 2008, p. 5). In the dawn of the automobile era, Ebenezer Howard's community was walkable so the residents could satisfy daily needs within a walkable distance.

- Later, in the 1920's, Clarence Perry introduced the concept of neighborhood unit concerned with the walkability to and from residential and non-residential areas for a fulfillment of residents' daily needs (Olson, 2013). Perry however determined the physical scale of the neighborhood "by the catchment area of the local primary school" (Chen, 2008, p. 2), and a population of five to six thousand people. Perry still emphasized the importance of a clear center and edge. 
Lynch (1984, p. 246) defines a neighborhood as a "spatial unit, free of through traffic and as self-sufficient in daily services as possible." The phrase "as possible" is important here because obviously no neighborhood can satisfy every resident's needs. Chen (2008, p. 2) adds that the importance of the concept of neighborhood in urban design stems from the desire to optimize the physical environment "to improve residents' lives."

The term neighborhood or neighborhood unit however, usually refers to .25 mile radius pedestrian sheds. The .25 mile radius pedestrian shed is "spatial proximity characterized by some sort of distance to be covered by citizens towards their daily destinations to satisfy ordinary needs" (Mehaffy, Porta, Rofè \& Salingaros 2010, p. 29).

Although the term center denotes a central location, some authors recommend that the best location for such shopping, office and retail areas is on the periphery of neighborhoods, where four or more neighborhoods meet (Mehaffy, Porta, Rofè \& Salingaros, 2010). Both Ebenezer Howard and Clarence Perry had reserved the central neighborhood locations for public buildings and uses and restricted commercial, retail, and office in the periphery. In reality, local conditions will determine appropriate or necessary locations of such centers as in the Tehachapi General Plan (Tehachapi General Plan, 2012). 


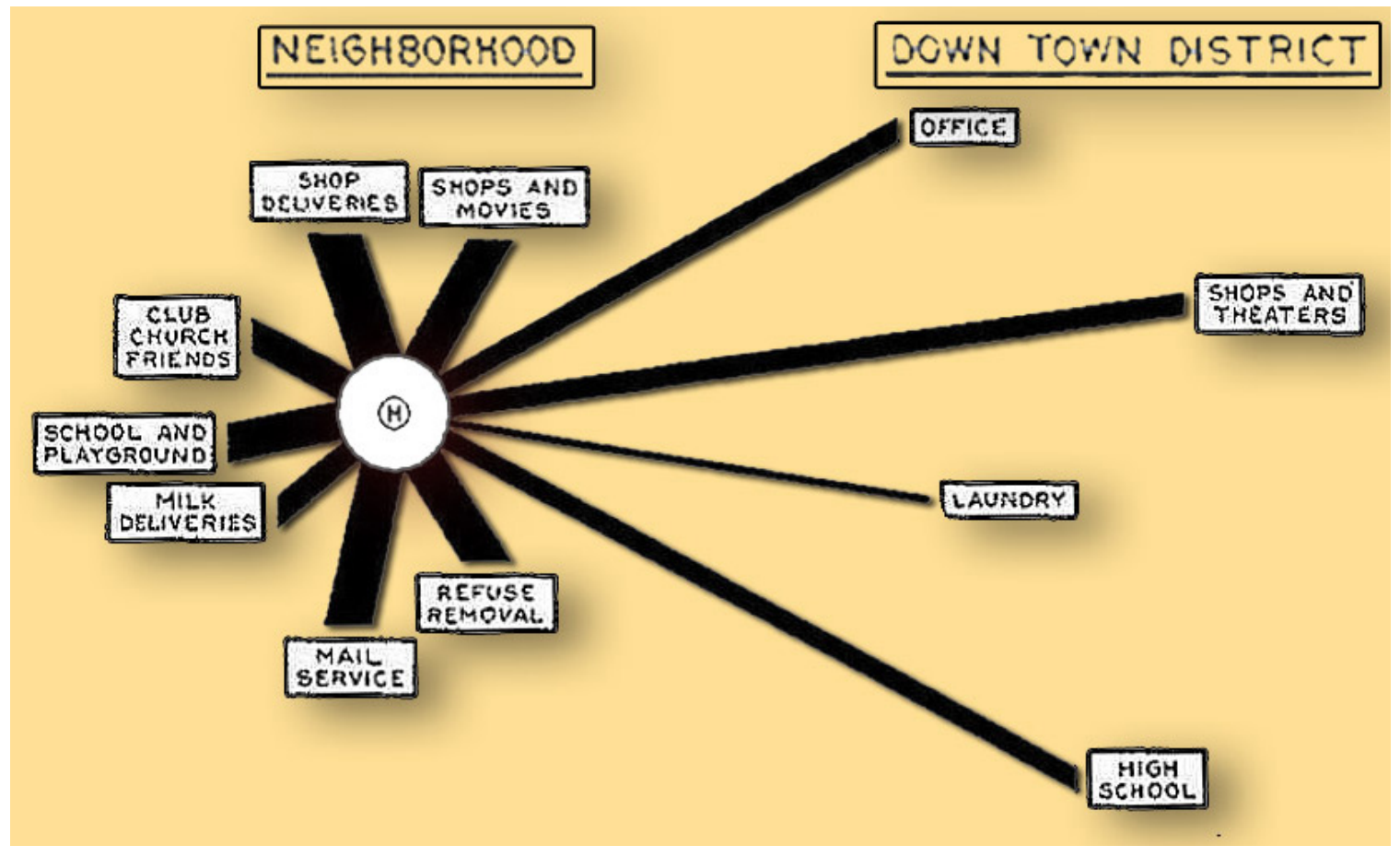

Figure 19: Clarence Perry's destinations of residents in neighborhoods and downtowns. Adapted from Neighborhood and Community Planning by Perry, 1929, p. 87.

Satisfaction of residents' daily needs implies a multitude of uses in close proximity to residential areas and therefore requires diversity of building types to accommodate a diversity of uses that would respond to residents' daily needs. In form-based codes, mixed-use buildings, a variety of housing options, locations designated for public buildings open spaces and zoning flexibility seem to cover most of the daily needs options. Therefore, Talen's (2012), Form and Use land impacts of zoning (Figure 2) are greatly affected by the presence of the variety of building and housing options.

Just like Ebenezer Howard (1902) was influenced by his visit in the picturesque and fledgling American towns of the 19th century (Mumford, 1965), so was Andres Duany influenced by the charm of many traditional towns of the East Coast contrasting to the sprawling subdivision developments of the late 20th century. Three sources provided information 
on the range of daily needs in a neighborhood, Andres Duany's exploration of traditional neighborhoods (Duany \& Plater-Zyberk, 1995), Portland's new Comprehensive Plan (City of Portland, 2014a, p. GP3-8), and Lavey's (Lavey, 2014) summary of walkability destinations in the Complete Builders' website. Lavey emphasizes that the more places there are, the more the opportunities of local residents to fulfill their basic daily needs on foot (see Appendix VI for a detailed exploration of daily need destinations from these sources). Clarence Perry in 1929 also presented a breakdown of daily destinations, left out of this analysis due to the dated nature of that era's destinations. Figure 19 shows Perry's historic diagram of two types of daily destinations in the late 1920's: local within the neighborhood and distant in the downtown. Based on these sources, the following are destinations that can provide an adequate fulfillment of residents' basic needs:

- A variety of housing options.

- A range of workplaces.

- Adequate retail stores and businesses (grocery stores, restaurants, corner stores, markets, shops, daycare centers etc.).

- Facilities for elementary education and high quality public schools.

- Culture such as museums and music venues.

- Civic amenities (government buildings, libraries, schools, community centers, places of worship, etc.).

- High quality parks, plazas or other public gathering places.

- Transit stops.

- Health clinics. 
The discussion on satisfying residents' daily needs is related to three neighborhood approaches, complete, sustainable, and self-sufficient neighborhoods. Complete neighborhoods directly relate to the goals of form-based codes since they address proximity, walkability and availability of building space for multiple use opportunities in neighborhood centers. Self-sufficiency and sustainability are topics related to the satisfaction of daily needs with sustainability is often equated to energy and food efficiency and self-sufficiency to a broad range of neighborhood parameters.

\subsubsection{Complete Neighborhoods}

The 2012 Portland Plan (City of Portland, 2014b) defines complete neighborhoods as:

A neighborhood where people have safe and convenient access to the goods and services needed in daily life, which include a variety of housing options, grocery stores and other commercial services, high-quality public schools, and parks. Complete neighborhoods are also easily accessible by foot, wheelchair, bike, and transit for people of all ages and abilities. (p. 76)

Complete neighborhoods incorporate ideas of multi-use neighborhood centers, clear identifiable neighborhood edges, and provide accessibility "to all users of the right-of-way regardless of age, ability, or mode of transportation" (City of Portland, 2014a, p. G-4). Proximity to daily needs is integral to complete neighborhoods that "host a mix of uses in order to provide for our daily need to live, work, play, worship, dine, shop, and talk to each other. Each neighborhood has a center, a general middle area and an edge" (Blackson, 2012).

\subsubsection{Neighborhood Sustainability and Self-sufficiency}

In a pilot program in Chattanooga, TN (Nooga, 2011), a self sustainable community was identified as integrating "all" aspects of a community such as housing, infrastructure, busi- 
nesses, playgrounds, and parks. Just like in Chattanooga, TN, in St. Luis, MI, a neighborhood self-sufficiency effort seems to be broader in scope than the complete neighborhood approach and addresses, infrastructure, health energy education, employment, arts and culture, diversity and equity, in addition to proximity to daily needs.

Sustainable neighborhoods or in the broader sense, sustainable urbanism, is also a broader than complete neighborhoods concept with a special focus on energy sufficiency, environmental protection, and social and economic vitality at the local level. "Local" is very important in both movements. Compact, walkable neighborhoods, and short distances to daily needs are part of the sustainable urbanism context (Thorpe, 2014).

\subsubsection{Proximity to Daily Needs Parameters in Form-Based Codes}

The requirement for a variety of businesses and stores within close proximity requires flexible buildings appropriately located, to provide the necessary building space and a variety of building types to accommodate a variety of retail, commercial or office in addition to a variety of housing to increase the possibilities for proximity to daily needs. Integral in the requirements for proximity to daily needs is the concept of a .25 mile walkable neighborhood with a center and edge. Such requirements can be easily be met by providing:

- Mixed use, retail, commercial, office presence in the center or periphery of the .25 mile pedestrian area.

- Residential within a .25 mile radius of mixed use/retail/commercial areas.

- A diversity of building types. 


\subsection{WALkabiLITY Principle}

\subsubsection{Definition}

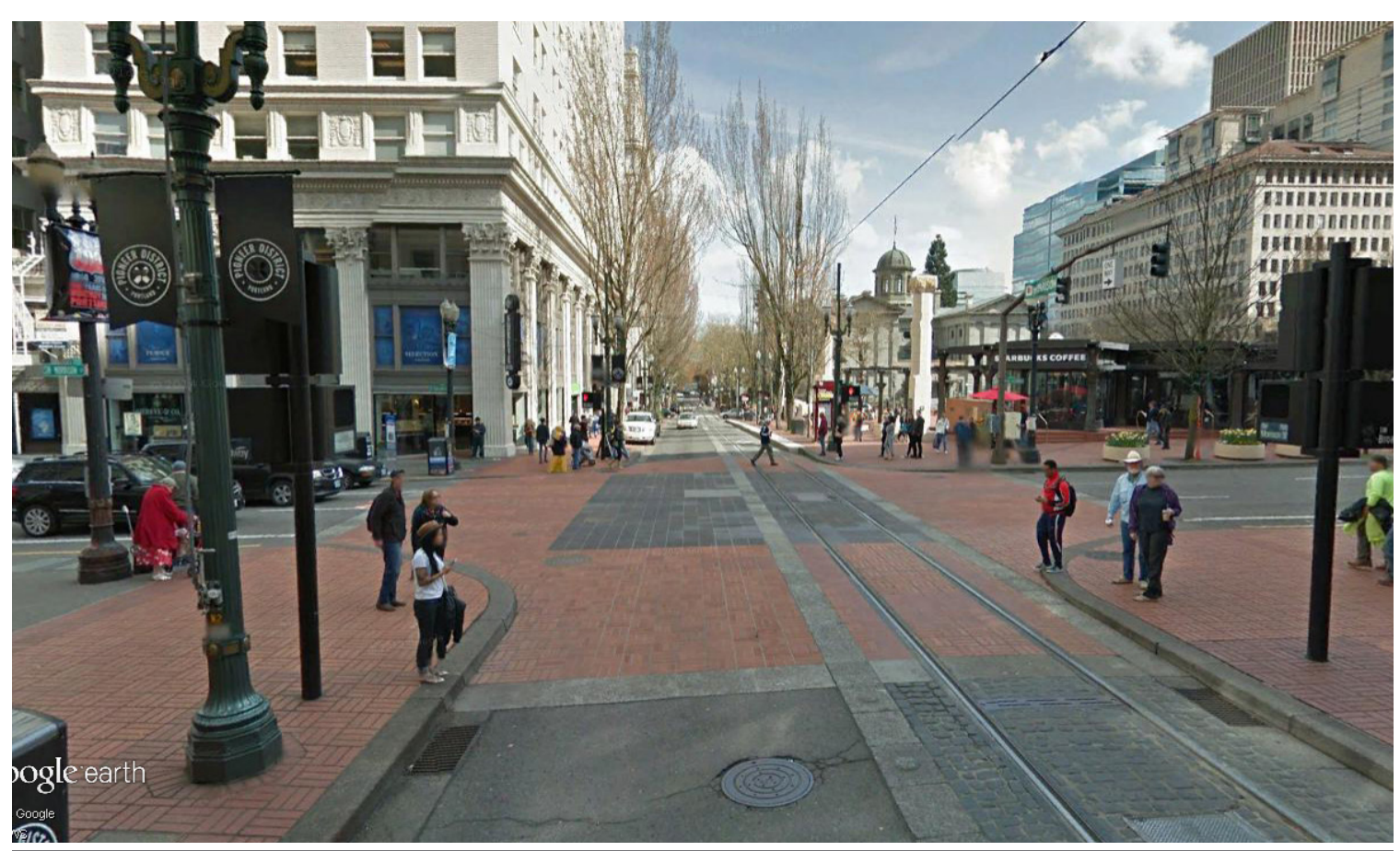

Figure 20: 722 SW Morrison Street next to Pioneer Courthouse Square in Portland Oregon (Google Earth Street View, 2014).

In GIS-related research, Rattan, Campese \& Eden (2012, p. 31) define walkability as "a measure of the effectiveness of community design in promoting walking and bicycling as alternatives to driving cars to reach shopping, schools, and other common destinations." Figures 20 and 21 show two scenes on Morrison Street, Portland Oregon, wellknown as a walkable city.

Walkable environments contribute to human health and the qualities that make an environment walkable are being investigated extensively in urban design literature and health-related fields. Both fields are still pursuing extensive research on the topic with results sometimes contradicting, often inconclusive, but nonetheless revolving around 
a few identified contributing built-environment qualities (Ewing \& Cervero, 2010, Choi, 2013). These qualities or parameters impact how inviting or not an area is to pedestrians and according to Jane's Walk (2014, para. 1) walkability is "a quantitative and qualitative measurement of how inviting or un-inviting an area is to pedestrians."

\subsubsection{Walkability Parameters}

The goal of this section is to identify parameters of the built environment that influence walkability so that it is clearer how walkability is, or can be applied, in the form-based code process. Walkability requires modifying and adapting the structure of neighborhoods to

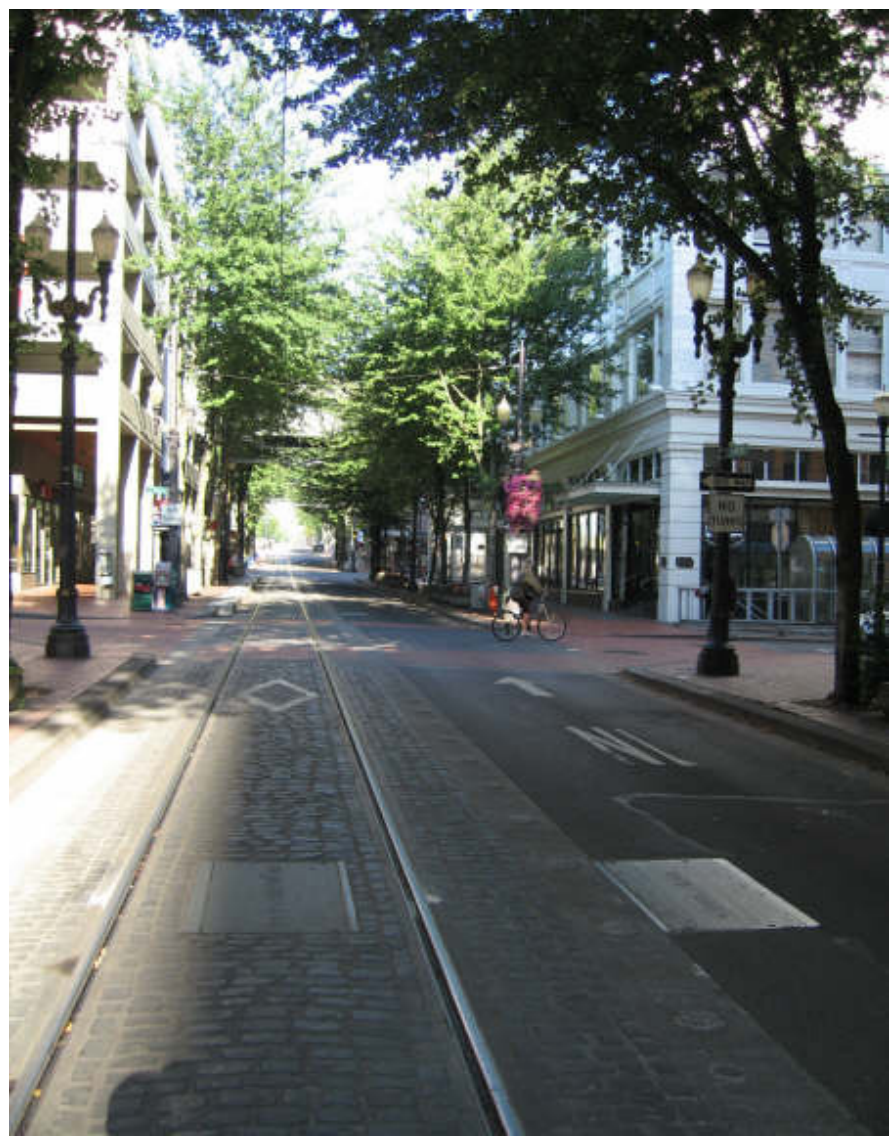

Figure 21: Walkable environment on Morrison Street early in the morning in Portland, Oregon (E. Evangelopoulos, personal photograph, August 2006). 
these parameters that reshape streets, sidewalks, and buildings. These parameters, some expressed as zoning standards, stand in contrast to standards in automobile-dependent neighborhoods enabled by Euclidean Zoning.

Parameters affecting walkability are often grouped under the so-called 5Ds, 4Ds, or 3Ps, rough and overlapping parameter categories as Ewing \& Cervero (2010) comment. As an example of overlap, the parameter intersection densities is often placed under either Design or Density.

It is important to emphasize Ewing \& Cervero's (2010) comment on walkability parameter categories as, rough and overlapping with parameters not only subject to change in the future, but also unable to significantly impact walkability individually. The cumulative effect of the parameters, however, is mentioned as significant. Therefore, instead of taking the frugal approach and eliminating parameters, all the parameters mentioned by the following authors are organized under the 5Ds for a more comprehensive look at walkability in the built environment. If parameters were listed under different Ds by different authors, a choice was made and placed under one only category. Many more studies exist that list similar walkability parameters with various findings of impact.

The seven studies selected are a meta analysis by Ewing \& Cervero (2010), the two major walkability websites of WalkScore (WalkScore, 2014) and Walkable Communities (Walkable Communities, Inc, 2014), an empirical and research combining analysis by Lavey \& Hill (2014a \& 2014b), the empirical and research bridging website Urban Imprint by professor Alfonso (2012), a GIS-based exploration of 3Ds by Rattan and Caprese (2012), and 
a composite walkability index that was developed and validated for Toronto and explored further by Glazier et al. (2014).

Ewing \& Cervero (2010) list the 5Ds of built-environment qualities that influence walkability and their analysis is important since it summarizes findings from numerous walkability studies:

- Density, that refers to "dwelling units, employment, building floor area, population, employment or something else" (p. 267).

- Diversity, that refers to the "number of different land uses in a given area and the degree to which they are represented in land area, floor area, or employment," jobs to housing or jobs-to-population (p. 267).

- Design, that includes street network or street parameters such as intersection density, street trees, street widths, sidewalk coverage and qualities, and other qualities that distinguish walkable environments.

- Destination/Accessibility, that refers to the "ease of access to trip attractions" and it can be the distance to the downtown, the number of jobs or attractions within a given distance or travel time or travel time from home to the nearest store.

- Distance to Transit, as the average distance to the nearest transit stop or station, distance between transit stops, number of transit stops per unit area, and transit route density.

In their meta analysis, Ewing \& Cervero (2010) tested the impact of built-environment parameters under the 5Ds and concluded the following 6 to be the most influential. The 
authors argue that these 6 parameters have a significant cumulative impact on walkability, although insignificant when each is considered separately:

- Land use mix (related to Diversity).

- Jobs-housing balance, (related to Density).

- Distance to a store, (related to Distance).

- Distance to a job, (related to Distance).

- Distance to a transit stop, (related to Distance).

- Intersection/street density, (related to Design).

Lavey \& Hill (2014b, adapted from Section: the D Variables) reference the 5Ds with slightly varied descriptions:

- "Density: There ore many attractions/amenities close together so that you can run several errands in a single trip on foot.

- Diversity: There is a diversity of housing options and a diversity of places to go- this includes parks, restaurants, shops, trails, etc.

- Design: The neighborhood is designed for people as well as for automobiles; building entrances are oriented to the street and parting lots are behind buildings.

- Destination: There are places to go that are open for business and provide services to residents.

- Distance: Attractions ore close enough that it is reasonable to walk to them."

Lavey \& Hill (2014a, Section: Three Key Principles) add a practitioner's point of view on walkability condensed in three major walkability principles dubbed as the 3Ps: 
- Physical Access that translates to adequate infrastructure to facilitate walking, such as safe and comfortable sidewalks and pedestrian friendly intersections (related to Destinations/Access).

- Proximity that refers to the 10 or 15 minute walk pedestrians are usually willing to walk before changing the mode of transportation. This represents a $1 / 4$ to $1 / 5$ mile radius from home to key destinations (related to Distance).

- Places that refers to the presence of a mix of destinations "providing enough diversity so that people have the opportunity to fulfill at least some of their daily and weekly needs" (Lavey \& Hill, 2014a, Section: Places to Go, Para.1). Such destinations are workplaces, corner stores/markets, schools, restaurants, retail, public spaces, parks, transit stops, and culture such as museums and music venues. Lavey also adds that the more places there are the more the opportunities for local residents to fulfill their basic daily needs on foot (related to Diversity).

Glazier et al. (2014), explore the impact of a walkability index, developed and validated for Toronto, CA, on transportation choices such as walking, and health factors, such as obesity, and they identify the following parameters influencing walkability:

- Population density as population per square kilometer (related to Density).

- Residential density as residences per square kilometer (related to Density).

- Destinations as the sum of retail and businesses including recreation and schools within 800 meters or .5 miles (related to Destinations/Access).

- Intersection density (related to Design). 
Glazier et al. (2014) found that the more present the above parameters are, the higher the walkability of an area in Toronto, CA and the higher the health effects on the population.

The WalkScore (WalkScore, 2014), and Walkable Communities (Walkable Communities, Inc, 2014) websites, identify the presence of enough people (density) as a key parameter for walkability as adequate population numbers to sustain the proximate businesses seems important. The WalkScore also mentions important, infrastructure (referring to streets adopted to bicyclists, pedestrians, and transit) and a pleasant environment (referring to attractive features along the walk), as important in the WalkScore website that rates walkability of neighborhoods across the country (Walkable Neighborhoods, 2014 \& Lavey \& Hill, 2014). (See Appendix V: Walkability parameters).

Rattan, Campese \& Eden (2012) determine walkability for the Halton Region in Ontario, Canada using GIS modeling and explore the following 3Ds:

- Density, as residential population density \& job density.

- Diversity, as percentage of residents within walking distance of defined diverse uses.

- Design, quantified as trail availability per 1,000 residents, bicycle path availability per 100 residents and number of intersections per square kilometer.

Mayne et al. (2013) refer to 'State of Place' website by Dr. Alfonzo, Assistant Research Professor at the Polytechnic Institute of New York University (Alfonzo, 2012) and mention the following 10 parameters, both research-based and practitioner-derived as important for walkability:

- Density as a measure of enclosure based on building concentrations and height. 
- Proximity as a measure of the presence of non-residential land uses (related to Distance).

- Connectivity as a measure of the presence of barriers such as six lane roads (related to Design).

- Form as a measure of streetscape discontinuity (related to Design).

- Parks and public spaces (related to Destinations/Access).

- Pedestrian Infrastructure/Amenities such as curbcuts, sidewalks, street furniture, and bike racks (related to Destinations/Access).

- Personal Safety such as litter, graffiti, windows with bars (related to Destinations/Access).

- Traffic measures such as traffic signals, Speed limits, and traffic calming (related to Destinations/Access).

- Aesthetics such as attractiveness, open views, outdoor dining, maintenance (related to Destinations/Access).

- Recreational facilities such as gym/fitness facilities, and other recreational uses (related to Destinations/Access).

What follows in Table 2 is a listing of walkability parameters from the references above using the umbrella of the 5Ds presented by Ewing \& Cervero (2010): Density, Diversity, Design, Destinations, and Distance. Parameters assigned to different Ds by different authors are assigned under a single $\mathrm{D}$. Jobs-housing balance for example was under either Density or Diversity depending on the author, so it were placed under one D only. Similar parameters listed by multiple authors are omitted. See Table 29 in Appendix $V$ for a list of walkability parameters by author. 


\begin{tabular}{|c|c|c|}
\hline $\begin{array}{l}\text { Density } \\
\text { of employment, popula- } \\
\text { tion, buildings, and desti- } \\
\text { nations. }\end{array}$ & $\begin{array}{l}\text { Diversity } \\
\text { of employment, land uses, hous- } \\
\text { ing, and destinations. }\end{array}$ & $\begin{array}{l}\text { Design } \\
\text { of intra-neighborhood connec- } \\
\text { tivity, path and trail connectiv- } \\
\text { ity, street pedestrian environ- } \\
\text { ment and buildings. }\end{array}$ \\
\hline $\begin{array}{l}\text { Employment } \\
\text { Employment/job den- } \\
\text { sity. } \\
\text { Employment in a giv- } \\
\text { en area. } \\
\text { Jobs-housing ratio/ } \\
\text { balance. } \\
\text { Jobs-to-population } \\
\text { ratio. }\end{array}$ & $\begin{array}{l}\text { Employment } \\
\text { - Diversity of Employment. }\end{array}$ & $\begin{array}{l}\text { Neighbor- } \\
\text { hood level connectivity } \\
\text { - Intersection density, (num- } \\
\text { ber of intersections per } \\
\text { square unit of area). } \\
\text { - Absence of barriers } \\
\text { such as six lane roads. } \\
\text { - A center: Walkable neigh- } \\
\text { borhoods have a cen- } \\
\text { ter, whether it's a main } \\
\text { street or a public space. }\end{array}$ \\
\hline $\begin{array}{l}\text { Population } \\
\text { - Population per } \\
\text { square unit of area. } \\
\text { - Dwelling units per } \\
\text { square unit of area. }\end{array}$ & $\begin{array}{l}\text { Land Uses } \\
\text { - Number of different land uses in a } \\
\text { given area/Degree to which differ- } \\
\text { ent land uses are represented in } \\
\text { a given area/Floor area of differ- } \\
\text { ent land uses in a given area. } \\
\text { - Land use mix. }\end{array}$ & $\begin{array}{l}\text { Path and trail connectivity } \\
\text { - Trail availability } \\
\text { per } 1,000 \text { residents. } \\
\text { - Bicycle path availabili- } \\
\text { ty per } 100 \text { residents. } \\
\text { - Path and trail internal and } \\
\text { street network connectivity. }\end{array}$ \\
\hline $\begin{array}{l}\text { Buildings } \\
\text { - Building floor area per } \\
\text { square unit of area. } \\
\text { - Dwelling units per } \\
\text { square unit of area. } \\
\text { - Measure of enclosure } \\
\text { based on building con- } \\
\text { centrations and height. }\end{array}$ & $\begin{array}{l}\text { Housing } \\
\text { - Diversity of housing options. }\end{array}$ & $\begin{array}{l}\text { Street and sidewalk level } \\
\text { pedestrian environment } \\
\text { - Street trees. } \\
\text { - Street widths. } \\
\text { - Sidewalk qualities. } \\
\text { - Form as a measure of } \\
\text { streetscape continuity (emp- } \\
\text { ty lots, blank walls). } \\
\text { - Other qualities that distin- } \\
\text { guish walkable environ- } \\
\text { ments and create complete } \\
\text { streets for bicyclists, pe- } \\
\text { destrians, and transit. }\end{array}$ \\
\hline $\begin{array}{l}\text { Attractions/Destinations } \\
\text { - Large number of des- } \\
\text { tinations/ attractions/ } \\
\text { amenities close togeth- } \\
\text { er so that you can run } \\
\text { several errands in a } \\
\text { single trip on foot. } \\
\text { - Number of transit } \\
\text { stops per unit area. }\end{array}$ & $\begin{array}{l}\text { Destinations } \\
\text { - Diversity and mix of places to } \\
\text { go - this includes parks, restau- } \\
\text { rants, shops, trails, etc. providing } \\
\text { enough diversity so that people } \\
\text { have the opportunity to fulfill at } \\
\text { least some of their daily and } \\
\text { weekly needs (workplaces, corner } \\
\text { stores/markets, schools, restau- } \\
\text { rants, retail, public spaces, parks, } \\
\text { transit stops, and culture such as } \\
\text { museums and music venues. } \\
\text { - Percentage of residents in walk- } \\
\text { ing distance of defined diverse } \\
\text { uses that provide a measure of } \\
\text { mixed-used development. }\end{array}$ & $\begin{array}{l}\text { Building level } \\
\text { pedestrian adaptations } \\
\text { - Buildings are } \\
\text { close to the street. } \\
\text { - Building entrances are } \\
\text { oriented to the street. } \\
\text { - Parking lots are } \\
\text { relegated to the back. } \\
\text { - Stores at a rea- } \\
\text { sonable square } \\
\text { footage for small towns. } \\
\text { - Building transparency. }\end{array}$ \\
\hline
\end{tabular}




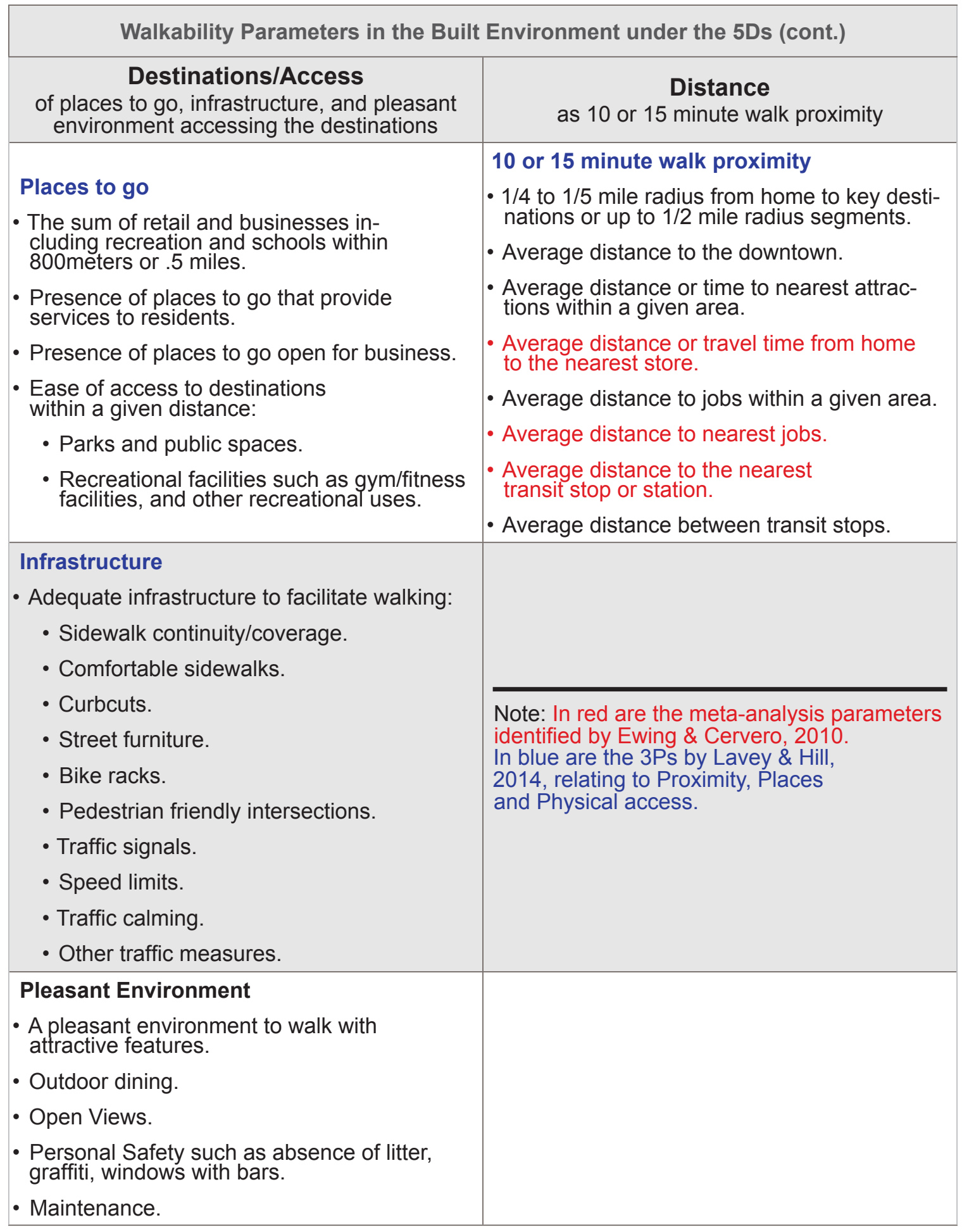




\subsubsection{Walkability Parameters Application in Form-Based Codes}

The exploration of walkability has identified built-environment parameters placed under the categories of the 5Ds of walkability: Density, Diversity, Design, Destination/Accessibility, and Distance as shown in Table 2. All walkability parameters impact pattern, form, and use, the three types of zoning impacts on the land according to Talen (2012) (see Figure 2).

In the form-based planning process, the walkability parameters identified are applicable both to the initial large scale analysis and planning, affecting the layout of city and neighborhoods, and to the block or street-level, coding standards phase, impacting street details as experienced by pedestrians. The following Section describes the main stages of the form-based code process. 


\subsection{The Form-Based Code Process}

\subsubsection{Form-Based Process}

According to Parolek, D., Parolek, K., \& Crawford, P. (2008), the form-based code process begins with the collection of information and assembling of the team, continues with the illustrative and regulating plan and ends with the actual code drafting. In the early code reform years, a form-based code was part of a master plan typical of Andres Duany projects such as Seaside, FL or the Birmingham, MI Downtown Master Plan of 1996 (City of Birmingham, MI, 2014). The term has evolved to include both the master plan (often called the illustrative or vision plan) and the form-based zoning code, and is often referred to as ‘Form-Based Planning' (Tony Perez, personal communication, July 1, 2014). Examples of form-based planning efforts, incorporating both design layout and zoning regulations, are the Cincinnati, OH, and the Daufuskie Island, SC codes (City of Cincinnati, 2014, and Beaufort County, SC, 2013).

\subsubsection{The Illustrative and Master Plans}

The illustrative plan is the result of the form-based code public outreach process involving a series of public charrettes laying down the desired urban form for the community. The charrettes integrate urban design principles with community preferences producing the illustrative or vision plan that is a rendered layout consisting of a detailed plan view, perspectives or other means that visually communicate a vision for the community's future form. The illustrative plan is often part of a master plan detailing the principles of development along with the community achieved vision. According to Parolek, D., Parolek, K., \& Crawford, P. (2008), a form-based zoning code is based on such an illustrative plan and 
ensures its implementation. See Figures 24, 25, 27, 28, 32, and 39 for examples of illustrative vision plans.

The illustrative plan process often lays out walkable neighborhoods of .25 mile radius with a center and an identifiable edge, followed by a hierarchy of urban intensity areas such as transects (Figure 36). While use-based codes split the city into use areas, form-based codes split the city into .25 mile neighborhoods followed by urban intensity areas within the neighborhoods.

\subsubsection{The Regulating Plan}

In the second step, the regulating plan, the intentions of the vision/illustrative plan are diagrammatically mapped showing neighborhoods, followed by a hierarchy of urban intensity areas representing regulating zones (often as transects). Denser regulating zones are laid around a central area in the neighborhood, or along a corridor. representing the neighborhood center, Concentrically, around the denser areas, less dense regulating zones are drawn (see Figures 6 and 7).

The regulating plan redraws many aspects of the illustrating plan in a diagrammatic form and clarifies the coding areas within each neighborhood. The focus shifts from the large city scale, to the neighborhood scale, and the clarification of use mix, retail and shopping areas, and residential areas. Making sure there is enough commercial and retail activity in the neighborhood to provide for the residents' daily needs within a walking distance 
becomes a major focus in this phase of form-based code process. The details of the walkable environment, will be set as standards in the next phase, the form-based zoning code.

\subsubsection{The Form-Based Zoning Code}

In the form-based zoning code phase, the directions of the illustrative and regulating plans need to be translated into standards that implement the community vision. Standards such as lot sizes, building heights, first floor fenestration, setbacks, curb radii and other features are used to create a walkable neighborhood and ensure the implementation of the illustrative plan vision. Figure 22 shows an example of form-based code zoning standards for the Town Core transect in the City of Benicia. The zoning standards depicted define building placement, use, and building height. Building placement standards include built-to-lines, setbacks, and building form. Use standards define allowable uses for the first and upper floors, while height standards define main and ancillery building heights and allowable floors, max height to top of parapet, first and upper floor ceiling heights and ground floor elevation in relation to the sidewalk.

Next Section presents six case studies at the neighborhood, county and city scale that explore the presence of the three quality of life principles in form-based code practice in all phases of form-based planning. 


\section{Town Core (TC) Standards}

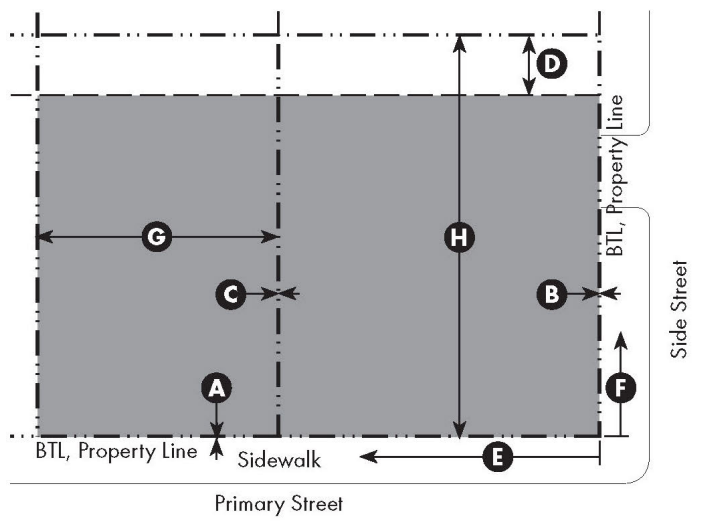

Key

---- Property Line

--- Build-to Line (BTL)

\begin{tabular}{|c|c|c|}
\hline Building & & \\
\hline Build-to Li & rop & \\
\hline Front & $0^{\prime}$ & A \\
\hline Side Street & $0^{\prime}$ & B \\
\hline
\end{tabular}

Setback (Distance from Property Line)

\begin{tabular}{lll}
\hline Side & $0^{\prime}$ & C \\
\hline
\end{tabular}

Rear

Adjacent to NG Zone

$8^{\prime}$

Adjacent to any other Zone

$5^{\prime}$

\begin{tabular}{lll}
\hline Building Form & & \\
\hline Primary Street Façade built to BTL & $80 \%$ min.* & E \\
\hline Side Street Façade built to BTL & $30 \%$ min. & E \\
\hline Lot Width & $125^{\prime} \max$. & ( \\
\hline Lot Depth & $100^{\prime} \max$. & ( \\
\hline
\end{tabular}

*Street façades must be built to BTL along first 30 ' from every corner. Notes

All floors must have a primary ground-floor entrance that faces the primary or side street.

Loading docks, overhead doors, and other service entries are prohibited on street-facing façades.

Any building over $50^{\prime}$ wide must be broken down to read as a series of buildings no wider than $50^{\prime}$ each.

4-6

Figure 22: Benicia form-based code Town Core zoning standards. From Downtown Mixed Use Master Plan. Ci.benicia.ca.us., by City of Benicia, CA, 2007. p. 4-6 and Opticos Design, Inc.

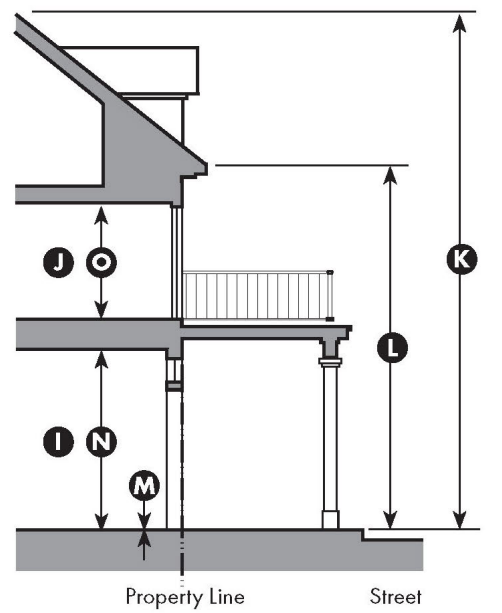

\begin{tabular}{lll}
\hline Use & \\
\hline Ground Floor & Service, Retail, or & \\
& Recreation, Education \& & \\
& Public Assembly & ( \\
\hline Upper Floor(s) & Residential or Service* & ( \\
\hline
\end{tabular}

*See Table 4.1 for specific uses. Ground floors that face the waterfront shall be nonresidential and shall not include parking,

D garages, or similar uses.

\begin{tabular}{lll}
\hline Height & & \\
\hline Building Min. & $22^{\prime}$ & B \\
\hline Building Max. & 2.5 stories and $40^{\prime}$ & B \\
\hline Max. to Eave/Top of Parapet & $35^{\prime}$ & ( \\
\hline Ancillary Building Max. & 2 stories and $25^{\prime}$ & \\
\hline Finish Ground Floor Level & $6^{\prime \prime}$ max. above sidewalk & $\mathbf{B}$ \\
\hline First Floor Ceiling Height & $12^{\prime}$ min. clear & $\mathbf{~ O}$ \\
\hline Upper Floor(s) Ceiling Height $8^{\prime}$ min. clear. & O \\
\hline
\end{tabular}
Notes

Mansard roof forms are not allowed.

Any section along the BTL not defined by a building must be

defined by a $2^{\prime} 6^{\prime \prime}$ to $4^{\prime} 6^{\prime \prime}$ high fence or stucco or masonry wall.

Downtown Mixed Use Master Plan Opticos Design, Inc. 


\subsection{Case Studies}

\subsubsection{Method}

\section{Overview}

So far, the quality of life intention in form-based codes was explored in the form-based code movement, identifying three contributing principles: neighborhood with a center and edge, proximity to daily needs and walkability. The history, origins and expressions of these principles over time was also explored along with implementation parameters for each principle.

Since every quality of life principle is now equipped with implementation parameters, the case studies will explore the presence of these parameters in current form-based code practices. The six form-based code case studies are retrieved from the FBCl's Library of Codes Web-page and have won the Driehaus Award except for one that received an honorable mention (Form-Based Code Institute, 2014b). The Form-Based Code Institute presents the Driehaus award annually with the support of the Richard $\mathrm{H}$. Driehaus Charitable Lead Trust:

The award recognizes excellence in the writing and implementation of form-based codes. Award winners include codes for corridors, neighborhoods, entire cities and even regions. The winning codes provide good examples for communities to study and learn from in their own efforts to write codes. (Form-Based Code Institute, 2014d, para. 1)

\section{Scale}

At all scales the form-based code is the implementation tool of a guiding master plan assembled after extensive community outreach and participation. Terminology and product 
assembling varies in each project. The Cincinnati Form-Based Code for example, incorporates the master plan under the form-based code title while the Farmers Branch Station Area Form-Based Code is a separate document, a follow-up to the master plan. The Benicia Downtown Master Plan on the other hand includes both the illustrative plan and the form-based code under the master plan title.

The case studies represent three scales of form-based code applications:

- Small downtowns or TODs at the neighborhood scale (approximately .25 mile radius) such as the Benicia, CA Downtown Master Plan and the Farmers Branch Station Area Master Plan and form-based code in the Dallas, TX vicinity.

- County-scale codes that address unincorporated areas and new development at the county level such as St Lucie and Lee Counties in Florida. These awarded case studies, although both in Florida, were crafted by separate firms with a varied approach in addressing community development.

- Large scale projects of multiple neighborhoods or at city-wide level such as the Cincinnati, $\mathrm{OH}$ and Peoria, IL Form-Based Codes.

\section{$\underline{\text { Principle and Parameter Evaluation }}$}

Case studies are explored using the three quality of life principles and their parameters identified in the previous section. Below is a list of these principles with their parameters and evaluations, adjusted to explore their presence in the form-based code process of the six awarded case studies: 


\section{Neighborhood principle parameters}

The presence or not of the parameters in each case study is answered with a yes, rated 1 , a no, rated 0 , or "partly," rated .5. If "partly' is used, then an explanation is provided at the end of the table under "notes. Table 3 lists the Neighborhood principle parameters as explored in the case studies.

\section{Table 3: Neighborhood principle parameters}

.25 mile or similar radius, or a 5 min walk neighborhood in any plan

Center with civic and/or mixed uses in any plan

Identifiable edge: discussion, mention, or delineations in any plan

\section{Proximity to Daily needs principle parameters}

The presence or not of the parameters in each case study is answered with a yes, rated

1 or no, rated 0 . Notes at the end of the table may provide explanation for some of the answers. Table 4 lists the Proximity to daily needs principle parameters as explored in all phases of the form-based code case studies .

\section{Table 4: Proximity to daily needs principle parameters}

Residential within .25 mile radius from mixed use/retail/commercial areas

Mixed use, retail, commercial, office development presence in illustrative plan

Mixed use, retail, commercial, office development presence in regulating plan

Mixed use, retail, commercial, office development presence in the zoning code

A diversity of building types in illustrative plan

A diversity of building types in regulating plan

A diversity of building types in the zoning code

Presence of various building types within the .25 mile radius neighborhood 


\section{Walkability principle parameters within the 5Ds}

The principle of Walkability is explored with 58 identified parameters, grouped under 16 parameter groups, under the sub-principles of the 5Ds: Density, Diversity, Design, Destinations, and Distance. Walkability is more complex than the other two principles and a yes or no evaluation is often not sufficient. Walkability parameters were assessed by the presence of "shall" regulations and standards within the form-based code. For this task, all standards and regulations (that included a "shall") from each zoning code were extracted and listed in an excel spread sheet for easier correlation of standards to walkability parameters. Appendix VII lists regulations and standards per case study. A "shall" regulation reflecting the walkability parameter is assigned a rating of 5 . If the existing urban conditions already satisfy this parameter, the parameter is rated 5 . If the specific pedestrian distance of .25 miles or similar is addressed in the code, the parameter is rated 5 . If the code provides some standards that address the parameter but more cold be done, the parameter is rated 4. If the code or the master plan included a "should," a guideline, or recommendation instead of a "shall" then the walkability parameter is assigned a rating of 2. If the parameter is not regulated, it is rated 1 . Table 5 lists all possible evaluations of a walkability parameter and Table 6 lists the 5Ds that incorporate 17 parameter groups and 58 identified parameters as explored in the form-based ode case studies.

\begin{tabular}{|c|c|l|}
\hline \multicolumn{2}{|c|}{ Table 5: } & Walkability Principle Parameter Criteria \\
\hline $\begin{array}{c}\text { Rating } \\
\mathbf{5} \\
\text { stron- } \\
\text { gest) }\end{array}$ & $\begin{array}{c}\text { Evaluation of parame- } \\
\text { ter presence in coding } \\
\text { standards. }\end{array}$ & Meaning \\
\hline 5 & yes & $\begin{array}{l}\text { The code includes "shall" regulations reflecting the walk- } \\
\text { ability parameter }\end{array}$ \\
\hline 5 & pre-existing & $\begin{array}{l}\text { The existing urban conditions already satisfy this param- } \\
\text { eter }\end{array}$ \\
\hline
\end{tabular}




\begin{tabular}{|c|c|l|}
\hline 5 & .25 to 5 miles & The specific pedestrian distance addressed in the code \\
\hline 4 & addressed & $\begin{array}{l}\text { The code provides some standards that address the pa- } \\
\text { rameter but more cold be done }\end{array}$ \\
\hline 3 & accommodated & $\begin{array}{l}\text { The parameter will likely be apparent through the imple- } \\
\text { mentation of other parameters included in the code. }\end{array}$ \\
\hline 2 & discussed & $\begin{array}{l}\text { No standards address the issue, however, recommen- } \\
\text { dations and discussions address the issue. }\end{array}$ \\
\hline 1 & not regulated & $\begin{array}{l}\text { The code does not include any information regarding } \\
\text { this parameter }\end{array}$ \\
\hline 1 & $\begin{array}{l}\text { or market determination } \\
\text { oased on demographics }\end{array}$ & $\begin{array}{l}\text { The parameter is assessed through information not } \\
\text { subject to he code or the master plan or information not } \\
\text { presented in the code or master plan. Possibly a spe- } \\
\text { cial study was done or would be helpful to address the } \\
\text { issue. }\end{array}$ \\
\hline
\end{tabular}

\section{Table 6: List of Walkability Principle parameters within the 5Ds}

\section{Density of:}

\begin{tabular}{|l|}
\hline \multicolumn{1}{|c|}{ Employment } \\
\hline - Employment/job density \\
\hline - Jobs-housing ratio/balance \\
\hline - Dopulation \\
\hline - Population per square unit of area, \\
\hline B Building floor area per square unit of area \\
\hline - Measure of enclosure based on building concentrations and height. \\
\hline \multicolumn{1}{|c|}{ Attractions/Destinations } \\
\hline - Large number of destinations/ attractions/amenities close together so that you can run sev- \\
eral errands in a single trip on foot. \\
\hline - Number of transit stops per unit area. \\
\hline Diversity of: \\
\hline - Diversity of Employment \\
\hline - Number of different land uses in a given area/Degree to which different land uses are repre- \\
\hline sented in a given area/Floor area of different land uses in a given area, \\
\hline Land use mix \\
\hline
\end{tabular}


- Diversity of housing options

\section{Destinations}

- Diversity and mix of places to go - this includes parks, restaurants, shops, trails, etc. providing enough diversity so that people have the opportunity to fulfill at least some of their daily and weekly needs (workplaces, corner stores/markets, schools, restaurants, retail, public spaces, parks, transit stops, and culture such as museums and music venues.

- Percentage of residents within walking distance of defined diverse uses that provide a measure of mixed-used development.

\section{Design of:}

\section{Neighborhood-level connectivity}

- Intersection density, (number of intersections per square unit of area)

- Absence of barriers such as six lane roads.

- A center: Walkable neighborhoods have a center, whether it's a main street or a public space.

\section{Path-trail connectivity}

- Trail availability per 1,000 residents,

- Bicycle path availability per 100 residents,

- Path/trail connectivity, internal and with street network.

\section{Street and sidewalk level pedestrian environment}

- Street trees,

- Street widths,

- Sidewalk qualities

- Form as a measure of streetscape continuity (empty lots, blank walls)

- Other qualities that distinguish walkable environments creating complete streets designed for bicyclists, pedestrians, and transit.

\section{Building level pedestrian adaptations}

- Buildings are close to the street

- Building entrances are oriented to the street

- Parking lots are relegated to the back

- Stores at a reasonable square footage for small towns

- Building transparency

\section{Destinations/Access:}

\section{Places to go}

- The sum of retail and businesses including recreation and schools within 800 meters or .5 miles.

- Presence of places to go that provide services to residents.

- Presence of places to go open for business

- Ease of access to destinations within a given distance: 
- Parks and public spaces

- Recreational facilities such as gym/fitness facilities, and other recreational uses

\section{Infrastructure}

Adequate infrastructure to facilitate walking, such as

- Sidewalk continuity/coverage

- Comfortable sidewalks

- Curbcuts,

- Street furniture

- Bike racks,

- Pedestrian friendly intersections.

- Traffic signals,

- Speed limits,

- Traffic calming,

- Other traffic measures

\section{Pleasant environment}

- A pleasant environment to walk with attractive features

- Outdoor dining,

- Personal Safety such as absence of litter, graffiti, windows with bars,

- Open Views,

- Maintenance.

\section{Distance}

\section{5 or 10 minute walk proximity}

- $1 / 4$ to $1 / 5$ mile radius from home to key destinations or up to $1 / 2$ mile radius segments.

- Average distance to the downtown,

- Average distance or time to nearest attractions within a given area

- Average distance or travel time from home to the nearest store.

- Average distance to jobs within a given area

- Average distance to nearest jobs,

- Average distance to the nearest transit stop or station,

- Average distance between transit stops 


\subsubsection{Farmers Branch Station Area, TX (2007 Driehaus Award)}

\section{Description}

The form-based code is an example of a form-based code for a compact town center area received a Driehaus award in 2007. Farmers Branch Station Area is planned as a mixeduse walkable project that corresponds to the quality of life parameters outlined above. It is, around one of the train stations on the new rail line from Dallas. The code addresses a downtown area of approximately 162 acres or .25 mile radius (Figure 23 ). The master plan promotes walking and bicycling within the project emphasizing the importance of the project as a transit oriented development along the new rail line. Planning for the downtown was underway for two decades with extensive community involvement in the final stages resulting in a master plan with an illustrative plan addressing land use and street concepts.

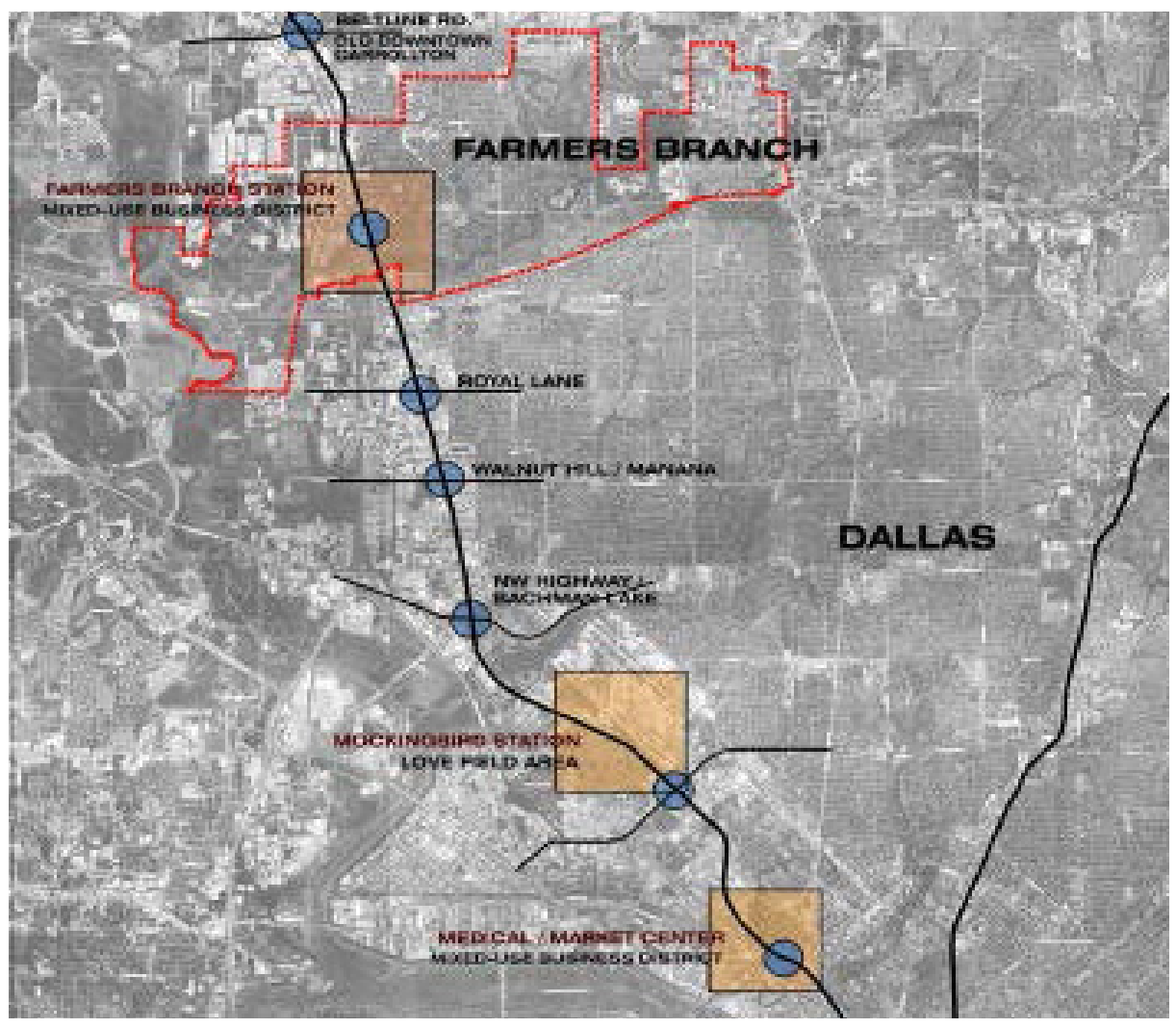

Figure 23: $\quad$ FarmersBranchStationAreainRelationtotheCityofFarmersBranchand the Rail Line from Dallas. From Farmers Branch Station Area Conceptual Master Plan by the City of Farmers Branch, TX, 2002, p. 2. 


\section{Neighborhood Principle}

Farmers Branch Station Area is touted in the Master Plan as:

...a unique, mixed-use urban-style neighborhood that blends retail uses, restaurants, personal and professional services, offices and housing in an environment that emphasizes walkable public spaces and creates a memorable experience for those living, working, shopping and visiting the neighborhood. The vision establishes a vibrant new town center that will not only serve the entire community for decades to come but also present a dynamic image of Farmers Branch to rest of the world. (City of Farmers Branch, 2002, p.1)

The illustrative plan envisions the project as both a neighborhood and a the new town center for the community of Farmers Branch. The development is about 162 acres with an approximate radial distance of .25 miles from center to edge. The concept of .25 mile walkable radius and the edge of the neighborhood are not discussed within the master plan. The 5 minute walk which is equivalent to the .25 mile walkable radius appears only as part the master and regulating plan logos. The zoning standards include regulations that address the block, the lot and the street. Figure 24 shows the Illustrative Plan for Farmers Branch Station Area and Table 7 presents the evaluation of the presence of neighborhood parameters in the Station Area Form-Based Code.

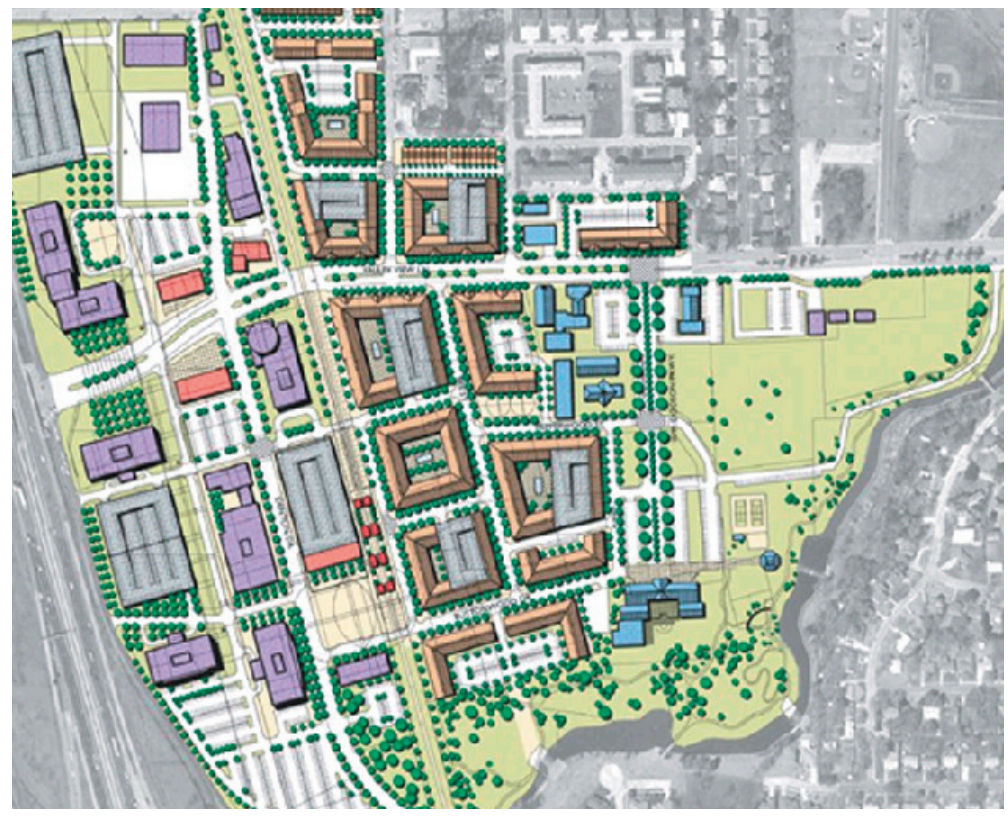

Figure 24: Farmers Branch Station Area Illustrative Plan. From Form-Based Code Station Area Ordinance 2800 by the City of Farmers Branch, TX, 2005, p. 10. 


\begin{tabular}{|l|l|l|}
\hline Table 7: Neighborhood Principle: Farmers Branch Station Area, TX \\
\hline .25 mile or similar radius or a 5 min walk neighborhood & yes & 1 \\
\hline Center with civic and/or mixed uses in illustrative plan & yes & 1 \\
\hline Identifiable edge: discussion, mention, or delineations in any plan & no & 0 \\
\hline Notes: 5 min walk reference in logo. & Total: & 2 \\
\hline
\end{tabular}

\section{Proximity to Daily Needs Principle}

The regulating plan specifies office, retail, and mixed use thus addressing the incorporation of stores, restaurants, and offices within the community creating proximity to daily destinations. Images and sketches of retail shop-fronts are part of the master plan expressing the desires of the community. The development is envisioned both as a neighborhood and a center to serve the whole town. The ability of the rest of the community to walk to this area is extended to .25 miles beyond the project. Since the community extends for 5 miles east of the Station however, walking will be prohibitive for most town residents but transit or bicycle transportation can be an option. One could argue daily needs could be served by short-distance automobile drives within this 5 mile distance, thus positively influencing residents' quality of life, reducing the need for longer trips. Table 8 presents the evaluation of the presence Proximity to Daily Needs Principle parameters in the Farmers Branch Station Area, TX Form-Based Code.

\begin{tabular}{|l|l|l|}
\hline Table 8: Proximity to Daily Needs Principle: Farmers Branch Station Area, TX \\
\hline Residential within .25 mile radius of mixed use/retail/commercial areas & yes & 1 \\
\hline $\begin{array}{l}\text { Mixed use, retail, commercial, office development presence in illustrative } \\
\text { plan }\end{array}$ & yes & 1 \\
\hline $\begin{array}{l}\text { Mixed use, retail, commercial, office development presence in regulating } \\
\text { plan }\end{array}$ & yes & 1 \\
\hline $\begin{array}{l}\text { Mixed use, retail, commercial, office development presence in the zoning } \\
\text { code }\end{array}$ & yes & 1 \\
\hline
\end{tabular}




\begin{tabular}{|l|l|l|}
\hline A diversity of building types in illustrative plan & yes & 1 \\
\hline A diversity of building types in regulating plan & yes & 1 \\
\hline A diversity of building types in the zoning code & yes & 1 \\
\hline Presence of building types within the .25 mile radius neighborhood & yes & 1 \\
\hline Notes:- & Total: & 8 \\
\hline
\end{tabular}

\section{Walkability Principle}

Station Area is designed to be walkable and bikeable. The master plan and the illustrative plans demonstrate this trough principles, recommendations and illustrations displaying aspects of density, diversity, design, distance and destinations as described in section.

Regulations for new development require blocks, lots, alleys, curb cuts, buildings, streetscape and parking to acquire characteristics that facilitate a walkable environment.

Walkability standards for new development blocks include, pedestrian pathways for larger than 400' blocks and only one per 200' curbcuts. Trees at less than 30' off-center are required along streets. Parking maximizes on-street parking, on street parking is part of the minimum requirement for shared parking, and parking requirements can be satisfied within 800 ' of a certain site. Specifications for streets include traffic lane widths, cub radii, sidewalk widths, tree planting areas, on-street parking configurations in an attempt to balance pedestrian, bicycle, transit and vehicular traffic.

Other building standards promote pedestrian views into the ground floor and require a $60 \%$ of the window pane area to allow ground floor views, prohibiting opaque treatments of first floor windows, allowing "interplay between shop interiors and street space" (City of Farmers Branch, 2014, p. 58). Walkability parameters of density, diversity, design, desti- 
nations, and distance were evaluated using the criteria shown on Table 5. Table 9 presents the evaluation of Walkability parameters within the 5Ds for the Farmers Branch Station Area form-based code.

\section{Table 9: Evaluation of Walkability parameters within the 5Ds}

\begin{tabular}{|c|c|c|c|}
\hline & D1_DENSITY & \multicolumn{2}{|c|}{ Station Area, TX } \\
\hline & D1 TOTAL & \multicolumn{2}{|l|}{18} \\
\hline \# & Employment & 4 & \\
\hline 1 & Employment/job density & acc & 3 \\
\hline \multirow[t]{2}{*}{2} & Jobs-housing ratio/balance & $\mathrm{nr}$ & 1 \\
\hline & Population & 6 & \\
\hline 3 & Population per square unit of area, & acc & 3 \\
\hline \multirow[t]{2}{*}{4} & Dwelling units per square unit of area, & acc & 3 \\
\hline & Buildings & 4 & \\
\hline 5 & Building floor area per square unit of area & acc & 3 \\
\hline \multirow[t]{2}{*}{6} & Measure of enclosure based on building concentrations and height. & $\mathrm{nr}$ & 1 \\
\hline & Attractions/Destinations & 4 & \\
\hline 7 & $\begin{array}{l}\text { Large number of destinations/ attractions/amenities close together so } \\
\text { that you can run several errands in a single trip on foot. }\end{array}$ & acc & 3 \\
\hline \multirow[t]{4}{*}{8} & Number of transit stops per unit area. & $\mathrm{nr}$ & 1 \\
\hline & D2_DIVERSITY & \multicolumn{2}{|c|}{ Station Area, TX } \\
\hline & $\begin{array}{l}\text { D2 TOTAL } \\
\text { MIN-MAX RANGE: } 6-30\end{array}$ & \multicolumn{2}{|l|}{14} \\
\hline & Employment & 1 & \\
\hline \multirow[t]{2}{*}{1} & Diversity of Employment & $\mathrm{nr}$ & 1 \\
\hline & Land Uses & 7 & \\
\hline 2 & $\begin{array}{l}\text { Number of different land uses in a given area/Degree to which differ- } \\
\text { ent land uses are represented in a given area/Floor area of different } \\
\text { land uses in a given area, }\end{array}$ & acc & 3 \\
\hline \multirow[t]{2}{*}{3} & Land use mix & acc & 3 \\
\hline & Housing & 1 & \\
\hline \multirow[t]{2}{*}{4} & Diversity of housing options & $\mathrm{nr}$ & 1 \\
\hline & Destinations & 6 & \\
\hline
\end{tabular}




\begin{tabular}{|c|c|c|c|}
\hline 5 & $\begin{array}{l}\text { Diversity and mix of places to go - this includes parks, restaurants, } \\
\text { shops, trails, etc. providing enough diversity so that people have the } \\
\text { opportunity to fulfill at least some of their daily and weekly needs } \\
\text { (workplaces, corner stores/markets, schools, restaurants, retail, pub- } \\
\text { lic spaces, parks, transit stops, and culture such as museums and } \\
\text { music venues. }\end{array}$ & acc & 3 \\
\hline \multirow[t]{4}{*}{6} & $\begin{array}{l}\text { Percentage of residents within walking distance of defined diverse } \\
\text { uses that provide a measure of mixed-used development. }\end{array}$ & acc & 3 \\
\hline & D3_DESIGN & \multicolumn{2}{|c|}{ Station Area, TX } \\
\hline & $\begin{array}{l}\text { D3 TOTAL } \\
\text { MIN-MAX RANGE: } 16-80\end{array}$ & \multicolumn{2}{|l|}{69} \\
\hline & Neighborhood-level connectivity & 15 & \\
\hline 1 & Intersection density, (number of intersections per square unit of area) & yes & 5 \\
\hline 2 & Absence of barriers such as six lane roads. & yes & 5 \\
\hline \multirow[t]{2}{*}{3} & $\begin{array}{l}\text { A center: Walkable neighborhoods have a center, whether it's a main } \\
\text { street or a public space. }\end{array}$ & yes & 5 \\
\hline & Path-trail connectivity & 7 & \\
\hline 4 & Trail availability per 1,000 residents, & acc & 3 \\
\hline 5 & Bicycle path availability per 100 residents, & acc & 3 \\
\hline \multirow[t]{2}{*}{6} & Path/trail connectivity, internal and with street network. & $\mathrm{nr}$ & 1 \\
\hline & Street and sidewalk level pedestrian environment & 22 & \\
\hline 7 & Street trees, & yes & 5 \\
\hline 8 & Street widths, & yes & 5 \\
\hline 9 & Sidewalk qualities & yes & 5 \\
\hline 10 & Form as a measure of streetscape continuity (empty lots, blank walls) & yes & 5 \\
\hline \multirow[t]{2}{*}{11} & $\begin{array}{l}\text { Other qualities that distinguish walkable environments creating com- } \\
\text { plete streets designed for bicyclists, pedestrians, and transit. }\end{array}$ & dis & 2 \\
\hline & Building level pedestrian adaptations & 25 & \\
\hline 12 & Buildings are close to the street & yes & 5 \\
\hline 13 & Building entrances are oriented to the street & yes & 5 \\
\hline 14 & Parking lots are relegated to the back & yes & 5 \\
\hline 15 & Stores at a reasonable square footage for small towns & yes & 5 \\
\hline \multirow[t]{4}{*}{16} & Building transparency & yes & 5 \\
\hline & D4_DESTINATIONS/ACCESS & \multicolumn{2}{|c|}{ Station Area, TX } \\
\hline & $\begin{array}{l}\text { D4 TOTAL } \\
\text { MIN-MAX RANGE: } 21-105\end{array}$ & \multicolumn{2}{|l|}{63} \\
\hline & Places to go & 21 & \\
\hline 1 & $\begin{array}{l}\text { The sum of retail and businesses including recreation and schools } \\
\text { within } 800 \text { meters or } .5 \text { miles. }\end{array}$ & acc & 3 \\
\hline 2 & Presence of places to go that provide services to residents. & acc & 3 \\
\hline 3 & Presence of places to go open for business & acc & 3 \\
\hline
\end{tabular}




\begin{tabular}{|c|c|c|c|}
\hline 4 & Ease of access to destinations within a given distance: & Wk & 5 \\
\hline 5 & Parks and public spaces & acc & 3 \\
\hline \multirow[t]{3}{*}{6} & $\begin{array}{l}\text { Recreational facilities such as gym/fitness facilities, and other recre- } \\
\text { ational uses }\end{array}$ & add & 4 \\
\hline & Infrastructure & 42 & \\
\hline & Adequate infrastructure to facilitate walking, such as: & 33 & \\
\hline 7 & Sidewalk continuity/coverage & yes & 5 \\
\hline 8 & Comfortable sidewalks & add & 4 \\
\hline 9 & Curbcuts, & add & 4 \\
\hline 10 & Street furniture & $\mathrm{nr}$ & 1 \\
\hline 11 & Bike racks, & $\mathrm{nr}$ & 1 \\
\hline 12 & Pedestrian friendly intersections. & add & 4 \\
\hline 13 & Traffic signals, & $\mathrm{nr}$ & 3 \\
\hline 14 & Speed limits, & $\mathrm{nr}$ & 3 \\
\hline 15 & Traffic calming, & add & 4 \\
\hline \multirow[t]{2}{*}{16} & Other traffic measures & add & 4 \\
\hline & Pleasant environment & 9 & \\
\hline 17 & A pleasant environment to walk with attractive features & acc & 3 \\
\hline 18 & Outdoor dining, & acc & 3 \\
\hline 19 & Personal Safety such as absence of litter, graffiti, windows with bars, & $\mathrm{nr}$ & 1 \\
\hline 20 & Open Views, & $\mathrm{nr}$ & 1 \\
\hline \multirow[t]{4}{*}{21} & Maintenance. & $\mathrm{nr}$ & 1 \\
\hline & D5_DISTANCE & \multicolumn{2}{|c|}{ Station Area, TX } \\
\hline & $\begin{array}{l}\text { D5 TOTAL } \\
\text { MIN-MAX RANGE: 8-40 }\end{array}$ & \multicolumn{2}{|l|}{34} \\
\hline & 5 or 10 minute walk proximity & & \\
\hline 1 & $\begin{array}{l}1 / 4 \text { to } 1 / 5 \text { mile radius from home to key destinations or up to } 1 / 2 \text { mile } \\
\text { radius segments. }\end{array}$ & yes & 5 \\
\hline 2 & Average distance to the downtown, & Wk & 5 \\
\hline 3 & Average distance or time to nearest attractions within a given area & add & 4 \\
\hline 4 & Average distance or travel time from home to the nearest store. & add & 4 \\
\hline 5 & Average distance to jobs within a given area & Wk & 5 \\
\hline 6 & Average distance to nearest jobs, & Wk & 5 \\
\hline 7 & Average distance to the nearest transit stop or station, & Wk & 5 \\
\hline 8 & Average distance between transit stops & $\mathrm{nr}$ & 1 \\
\hline
\end{tabular}




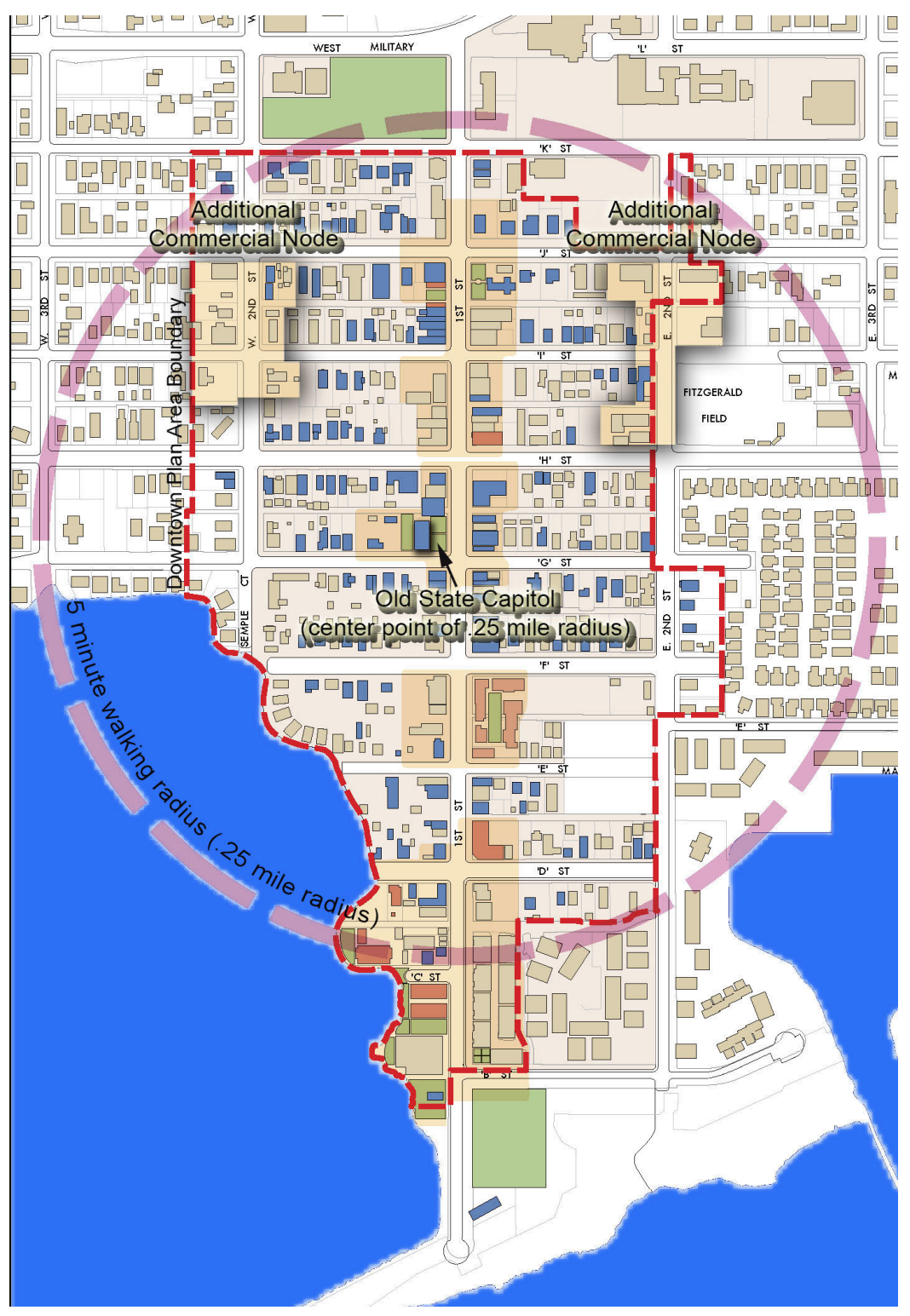

Figure 25: Benicia Downtown Illustrative Framework Plan. Adapted from Downtown Mixed Use Master Plan. Ci.benicia.ca.us., by City of Benicia, CA, 2007. p. 3-3.

\section{Description}

This form-based code is part of the Downtown Mixed-Use Master Plan providing the necessary regulatory framework to ensure compatibility of mixed use development within the historic context of the project area. It establishes four zones (transect-based) with clearly 
illustrated standards for each zone, frontage types and additional standards common to all zones. A visioning workshop, intensive physical and economic analysis and a community design workshop lead to the vision illustrative plan and the land use regulating plan for downtown Benicia that includes most of the historic downtown district. Place-specific design recommendations and a focus on community sustainability reflect major goals of the Downtown Mixed-Use Master Plan that received the Driehaus award in 2008.

\section{Neighborhood Principle}

The Benicia Downtown mixed use Master Plan concerns an area of about .25 radius. The goal of the plan is to integrate mixed-use development within the existing historic fabric of the downtown. The concept of a .25 mile radius neighborhood with a center is part of the conceptual principles of the downtown master plan. The town center is planned for both local and tourist activity while two additional neighborhood serving centers are specified within the .25 radius (Figure 25 ). Although the historic downtown is partly bounded by water that creates a strong neighborhood edge, there is no discussion within the Master Plan of the concept of a neighborhood edge. Table 10 presents the evaluation of the presence of neighborhood parameters in the Benicia, CA Downtown Mixed Use Master Plan.

\section{Table 10: Neighborhood Principle: Benicia, CA Downtown Mixed Use Master Plan}

\begin{tabular}{|l|l|l|}
\hline .25 mile or similar radius or a 5 min walk neighborhood in any plan & yes & 1 \\
\hline Center with civic and/or mixed uses in any plan & yes & 1 \\
\hline Identifiable edge: discussion, mention, or delineations in any plan & no & 0 \\
\hline Notes: & Total: & 2 \\
\hline
\end{tabular}


Proximity to Daily Needs Principle

The project is designed to incorporate mixed-use development into the historic downtown and, in addition it creates two neighborhood-focused retail centers that correspond to the two major proximity to daily needs parameters identified, mixed use and diversity of build-

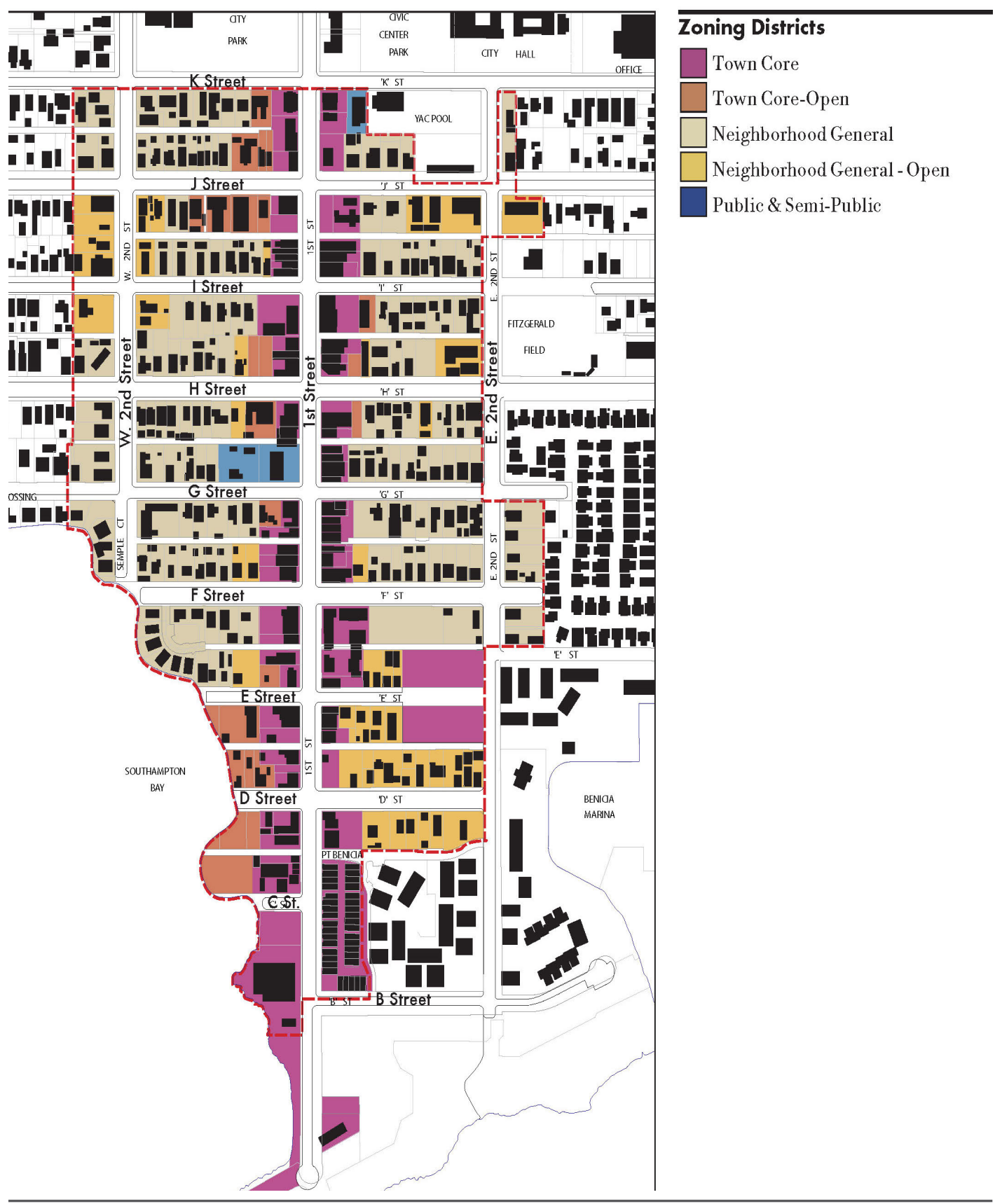

Figure 26: City of Benicia Downtown Regulating Plan. Adapted from Downtown Mixed Use Master Plan. Ci.benicia.ca.us., by City of Benicia, CA, 2007. p. 4-3. 
ings. Figure 26 shows the Benicia regulating plan and the prescribed diversity of uses. Table 11 presents the evaluation of the presence Proximity to Daily Needs Principle parameters in the Benicia, CA Downtown Mixed Use Master Plan.

\begin{tabular}{|l|l|l|}
\hline $\begin{array}{l}\text { Table 11: Proximity to Daily Needs Principle: Benicia, CA Downtown Mixed Use Master } \\
\text { Plan }\end{array}$ \\
\hline Residential within .25 mile radius from mixed use/retail/commercial areas & yes & 1 \\
\hline $\begin{array}{l}\text { Mixed use, retail, commercial, office development presence in illustrative } \\
\text { plan }\end{array}$ & yes & 1 \\
\hline $\begin{array}{l}\text { Mixed use, retail, commercial, office development presence in regulating } \\
\text { plan }\end{array}$ & yes & 1 \\
\hline $\begin{array}{l}\text { Mixed use, retail, commercial, office development presence in the zoning } \\
\text { code }\end{array}$ & yes & 1 \\
\hline A diversity of building types in illustrative plan & yes & 1 \\
\hline A diversity of building types in regulating plan & yes & 1 \\
\hline A diversity of building types in the zoning code & yes & 1 \\
\hline Presence of building types within the .25 mile radius neighborhood & yes & 1 \\
\hline Notes: & Total: & 8 \\
\hline
\end{tabular}

Walkability Principle

The project is designed as a walkable mixed-use neighborhood addressing many walkability parameters. Some parameters, such as intersection density are already pre-existing and helping walkability, while Destination/Accessibility parameters of street/sidewalk infrastructure and pleasant environment are not fully addressed by the code.

Walkability parameters of density, diversity, design, destinations, and distance were evaluated using the criteria shown on Table 5. Table 12 presents the evaluation of Walkability parameters within the 5Ds for the Benicia, CA Downtown Mixed-Use Master Plan: 


\begin{tabular}{|c|c|c|c|}
\hline & D1_DENSITY & \multicolumn{2}{|c|}{ Benicia, CA } \\
\hline & $\begin{array}{l}\text { D1 TOTAL } \\
\text { MIN-MAX RANGE: } 8-40\end{array}$ & \multicolumn{2}{|l|}{22} \\
\hline \# & Employment & 4 & \\
\hline 1 & Employment/job density & acc & 3 \\
\hline \multirow[t]{2}{*}{2} & Jobs-housing ratio/balance & $\mathrm{nr}$ & 1 \\
\hline & Population & 6 & \\
\hline 3 & Population per square unit of area, & acc & 3 \\
\hline \multirow[t]{2}{*}{4} & Dwelling units per square unit of area, & acc & 3 \\
\hline & Buildings & 7 & \\
\hline 5 & Building floor area per square unit of area & acc & 3 \\
\hline \multirow[t]{2}{*}{6} & Measure of enclosure based on building concentrations and height. & add & 4 \\
\hline & Attractions/Destinations & 5 & \\
\hline 7 & $\begin{array}{l}\text { Large number of destinations/ attractions/amenities close together so that } \\
\text { you can run several errands in a single trip on foot. }\end{array}$ & acc & 3 \\
\hline \multirow[t]{4}{*}{8} & Number of transit stops per unit area. & dis & 2 \\
\hline & D2_DIVERSITY & \multicolumn{2}{|c|}{ Benicia, CA } \\
\hline & $\begin{array}{l}\text { D2 TOTAL } \\
\text { MIN-MAX RANGE: } 6-30\end{array}$ & \multicolumn{2}{|l|}{20} \\
\hline & Employment & 3 & \\
\hline \multirow[t]{2}{*}{1} & Diversity of Employment & acc & 3 \\
\hline & Land Uses & 11 & \\
\hline 2 & $\begin{array}{l}\text { Number of different land uses in a given area/Degree to which different } \\
\text { land uses are represented in a given area/Floor area of different land } \\
\text { uses in a given area, }\end{array}$ & acc & 3 \\
\hline \multirow[t]{2}{*}{3} & Land use mix & yes & 5 \\
\hline & Housing & 3 & \\
\hline \multirow[t]{2}{*}{4} & Diversity of housing options & acc & 3 \\
\hline & Destinations & 6 & \\
\hline 5 & $\begin{array}{l}\text { Diversity and mix of places to go - this includes parks, restaurants, shops, } \\
\text { trails, etc. providing enough diversity so that people have the opportunity } \\
\text { to fulfill at least some of their daily and weekly needs (workplaces, corner } \\
\text { stores/markets, schools, restaurants, retail, public spaces, parks, transit } \\
\text { stops, and culture such as museums and music venues. }\end{array}$ & acc & 3 \\
\hline 6 & $\begin{array}{l}\text { Percentage of residents within walking distance of defined diverse uses } \\
\text { that provide a measure of mixed-used development. }\end{array}$ & acc & 3 \\
\hline & D3_DESIGN & \multicolumn{2}{|c|}{ Benicia, CA } \\
\hline
\end{tabular}




\begin{tabular}{|c|c|c|c|}
\hline & $\begin{array}{l}\text { D3 TOTAL } \\
\text { MIN-MAX RANGE: } 16-80\end{array}$ & \multicolumn{2}{|l|}{55} \\
\hline & Neighborhood-level connectivity & 15 & \\
\hline 1 & Intersection density, (number of intersections per square unit of area) & pre & 5 \\
\hline 2 & Absence of barriers such as six lane roads. & pre & 5 \\
\hline \multirow[t]{2}{*}{3} & $\begin{array}{l}\text { A center: Walkable neighborhoods have a center, whether it's a main } \\
\text { street or a public space. }\end{array}$ & yes & 5 \\
\hline & Path-trail connectivity & 4 & \\
\hline 4 & Trail availability per 1,000 residents, & $\mathrm{nr}$ & 1 \\
\hline 5 & Bicycle path availability per 100 residents, & dis & 2 \\
\hline \multirow[t]{2}{*}{6} & Path/trail connectivity, internal and with street network. & $\mathrm{nr}$ & 1 \\
\hline & Street and sidewalk level pedestrian environment & 15 & \\
\hline 7 & Street trees, & $\mathrm{nr}$ & 1 \\
\hline 8 & Street widths, & add & 4 \\
\hline 9 & Sidewalk qualities & add & 4 \\
\hline 10 & Form as a measure of streetscape continuity (empty lots, blank walls) & add & 4 \\
\hline \multirow[t]{2}{*}{11} & $\begin{array}{l}\text { Other qualities that distinguish walkable environments creating complete } \\
\text { streets designed for bicyclists, pedestrians, and transit. }\end{array}$ & dis & 2 \\
\hline & Building level pedestrian adaptations & 21 & \\
\hline 12 & Buildings are close to the street & yes & 5 \\
\hline 13 & Building entrances are oriented to the street & yes & 5 \\
\hline 14 & Parking lots are relegated to the back & yes & 5 \\
\hline 15 & Stores at a reasonable square footage for small towns & yes & 5 \\
\hline \multirow[t]{4}{*}{16} & Building transparency & $\mathrm{nr}$ & 1 \\
\hline & D4_DESTINATIONS/ACCESS & \multicolumn{2}{|c|}{ Benicia, CA } \\
\hline & $\begin{array}{l}\text { D4 TOTAL } \\
\text { MIN-MAX RANGE: } 21-105\end{array}$ & \multicolumn{2}{|l|}{40} \\
\hline & Places to go & 21 & \\
\hline 1 & $\begin{array}{l}\text { The sum of retail and businesses including recreation and schools within } \\
800 \text { meters or } .5 \text { miles. }\end{array}$ & $\mathrm{nr}$ & 1 \\
\hline 2 & Presence of places to go that provide services to residents. & acc & 3 \\
\hline 3 & Presence of places to go open for business & acc & 3 \\
\hline 4 & Ease of access to destinations within a given distance: & Wk & 5 \\
\hline 5 & Parks and public spaces & yes & 5 \\
\hline \multirow[t]{3}{*}{6} & $\begin{array}{l}\text { Recreational facilities such as gym/fitness facilities, and other recreational } \\
\text { uses }\end{array}$ & add & 4 \\
\hline & Infrastructure & 19 & \\
\hline & Adequate infrastructure to facilitate walking, such as: & 10 & \\
\hline 7 & Sidewalk continuity/coverage & $\mathrm{nr}$ & 1 \\
\hline
\end{tabular}




\begin{tabular}{|l|l|l|l|}
\hline 8 & Comfortable sidewalks & $\mathrm{nr}$ & 1 \\
\hline 9 & Curbcuts, & $\mathrm{nr}$ & 1 \\
\hline 10 & Street furniture & $\mathrm{nr}$ & 1 \\
\hline 11 & Bike racks, & $\mathrm{nr}$ & 1 \\
\hline 12 & Pedestrian friendly intersections. & $\mathrm{nr}$ & 1 \\
\hline 13 & Traffic signals, & $\mathrm{nr}$ & 1 \\
\hline 14 & Speed limits, & $\mathrm{nr}$ & 1 \\
\hline 15 & Traffic calming, & $\mathrm{nr}$ & 1 \\
\hline 16 & Other traffic measures & $\mathrm{nr}$ & 1 \\
\hline & Pleasant environment & 9 & \\
\hline 17 & A pleasant environment to walk with attractive features & $\mathrm{acc}$ & 3 \\
\hline 18 & Outdoor dining & $\mathrm{acc}$ & 3 \\
\hline 19 & Personal Safety such as absence of litter, graffiti, windows with bars, & $\mathrm{nr}$ & 1 \\
\hline 20 & Open Views, & $\mathrm{nr}$ & 1 \\
\hline 21 & Maintenance. & $\mathrm{nr}$ & 1 \\
\hline & & & \\
\hline & D5_DISTANCE & $\mathrm{Benicia}, \mathrm{CA}$ \\
\hline & D5 TOTAL & 37 & \\
\hline & MIN-MAX RANGE: 8-40 & $\mathrm{Wk}$ & 5 \\
\hline & 5 or 10 minute walk proximity & $\mathrm{Wk}$ & 5 \\
\hline 1 & $\begin{array}{l}\text { 1/4 to 1/5 mile radius from home to key destinations or up to 1/2 mile radi- } \\
\text { us segments. }\end{array}$ & $\mathrm{yes}$ & 5 \\
\hline 2 & Average distance to the downtown, & $\mathrm{Wk}$ & 5 \\
\hline 3 & Average distance or time to nearest attractions within a given area & $\mathrm{Wk}$ & 5 \\
\hline 4 & Average distance or travel time from home to the nearest store. & $\mathrm{dis}$ & 2 \\
\hline 5 & Average distance to jobs within a given area & & 5 \\
\hline 6 & Average distance to nearest jobs, & $\mathrm{Wk}$ & 5 \\
\hline 7 & Average distance to the nearest transit stop or station, & & \\
\hline 8 & Average distance between transit stops & & \\
\hline & & & \\
\hline
\end{tabular}




\section{Project Description}

The northwest St. Lucie County Towns, Villages and Countryside (TVC) Overlay Comprehensive Plan and Form-Based Code aim at preserving agricultural land while concentrating development in a few compact villages. The code describes the process for assigning transects and standards to developable land. Every new development is approved by the County Commission as a PUD plan. The Plan was a result of a lengthy public participation process producing a comprehensive plan, a master plan and an overlay form-based code. Figure 27 shows the Northwest St Lucie County Master Plan with proposed configurations of new urban areas with a clear center and edge.

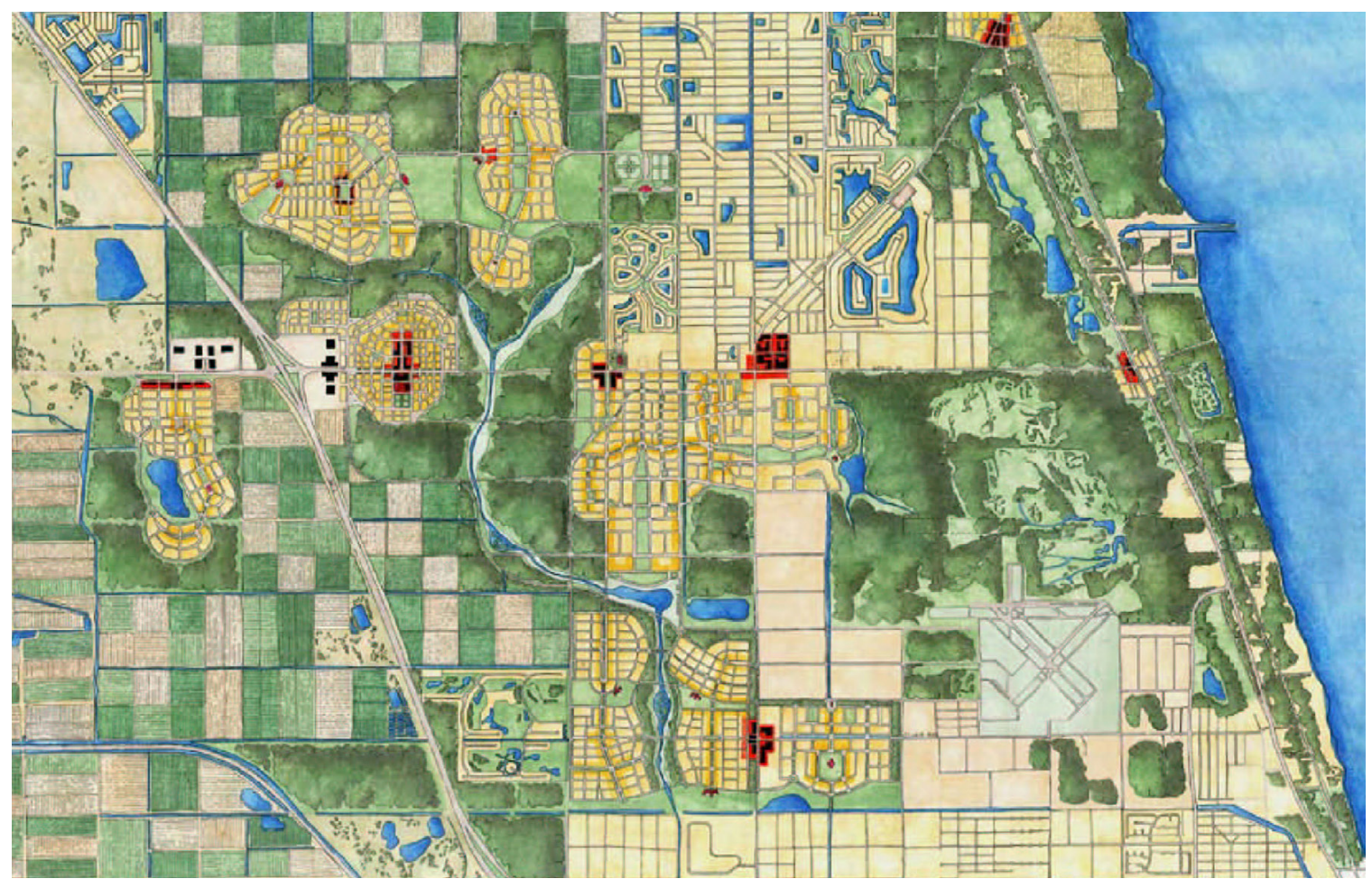

Figure 27: Northwest St Lucie County Towns Villages and Countryside (TVC) Master Plan showing proposed configurations of new urban areas with a clear center and edge. Adapted from North St. Lucie County Charrette by St Lucie County, \& Treasure Coast Regional Planning Council, 2004, p 2. 


\section{Neighborhood Principle}

The county-wide code received a Driehaus award in 2007 and designed by DPZ. The code requires the definition of a center and edge within the PTV (Planned Town or Village) zoning district. Different transects define urban intensity from the center (Core Transect) towards a clearly identifiable rural edge (Rural Transect). Figure 28 shows the application of the .25 mile radius in proposed new town illustrative plans. Table 13 presents the evaluation of the presence of Neighborhood parameters in the St. Lucie County, FL ,Towns, Villages and Countryside (TVC) Overlay Form-Based Code.

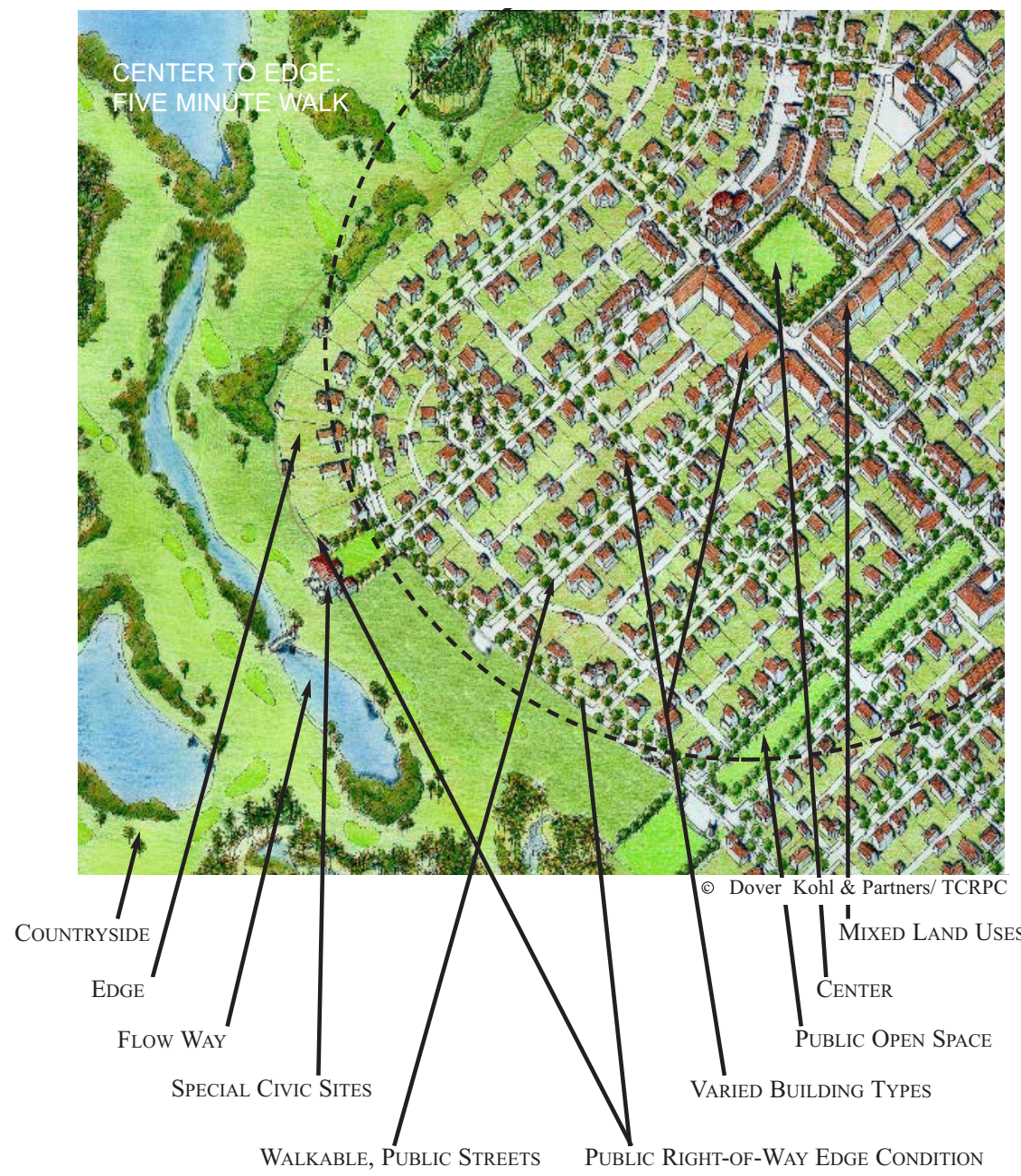

Figure 28: St. Lucie County Towns, Villages and Countryside (TVC) 5 minute walk neighborhood structure illustrative plan. Adapted from Towns, Villages and the Countryside A New Pattern of Settlement for North St. Lucie County, by St Lucie County, \& Treasure Coast Regional Planning Council, 2006, p. 3-12. 


\begin{tabular}{|c|c|c|}
\hline 25 mile or similar radius or a 5 min walk neighborhood in any plan & yes & 1 \\
\hline Center with civic and/or mixed uses in any plan & yes & 1 \\
\hline Identifiable edge: discussion, mention, or delineations in any plan & yes & 1 \\
\hline Notes & Total: & 3 \\
\hline
\end{tabular}

\section{Proximity to Daily Needs Principle}

This form-based code is organized by transect and building types. The proposed diversity of building types and transects cover the principles outlined in the daily need requirements while walkability seems to be a more elusive. Building density and height, lot coverage, proximity and the .25 mile radius are addressed in the code but pleasant environment is a more elusive concept for the codes to address probably needing the input of designers.

The same probably with destinations relying mostly on the diversity of buildings and an effective chamber of commerce or downtown association. Pedestrian, bicycle and transit infrastructure is not addressed in the code while intersection density is. Figure 29 shows location of new retail/workplace uses at key intersections in St Lucie County and Figure 30 shows a sample regulating plan. Table 14 presents the evaluation of the presence of Proximity to Daily Needs parameters in the St. Lucie County, FL, Towns, Villages and Countryside (TVC) Overlay Form-Based Code.

\begin{tabular}{|c|c|c|}
\hline Residential within .25 mile radius from mixed use/retail/commercial areas & yes & 1 \\
\hline Mixed use, retail, commercial, office development presence in illustrative plan & yes & 1 \\
\hline Mixed use, retail, commercial, office development presence in regulating plan & yes & 1 \\
\hline Mixed use, retail, commercial, office development presence in the zoning code & yes & 1 \\
\hline
\end{tabular}




\begin{tabular}{|l|l|l|}
\hline A diversity of building types in illustrative plan & yes & 1 \\
\hline A diversity of building types in regulating plan & yes & 1 \\
\hline A diversity of building types in the zoning code & yes & 1 \\
\hline Presence of various building types within the .25 mile radius neighborhood & yes & 1 \\
\hline Notes: & Total: & 8 \\
\hline
\end{tabular}
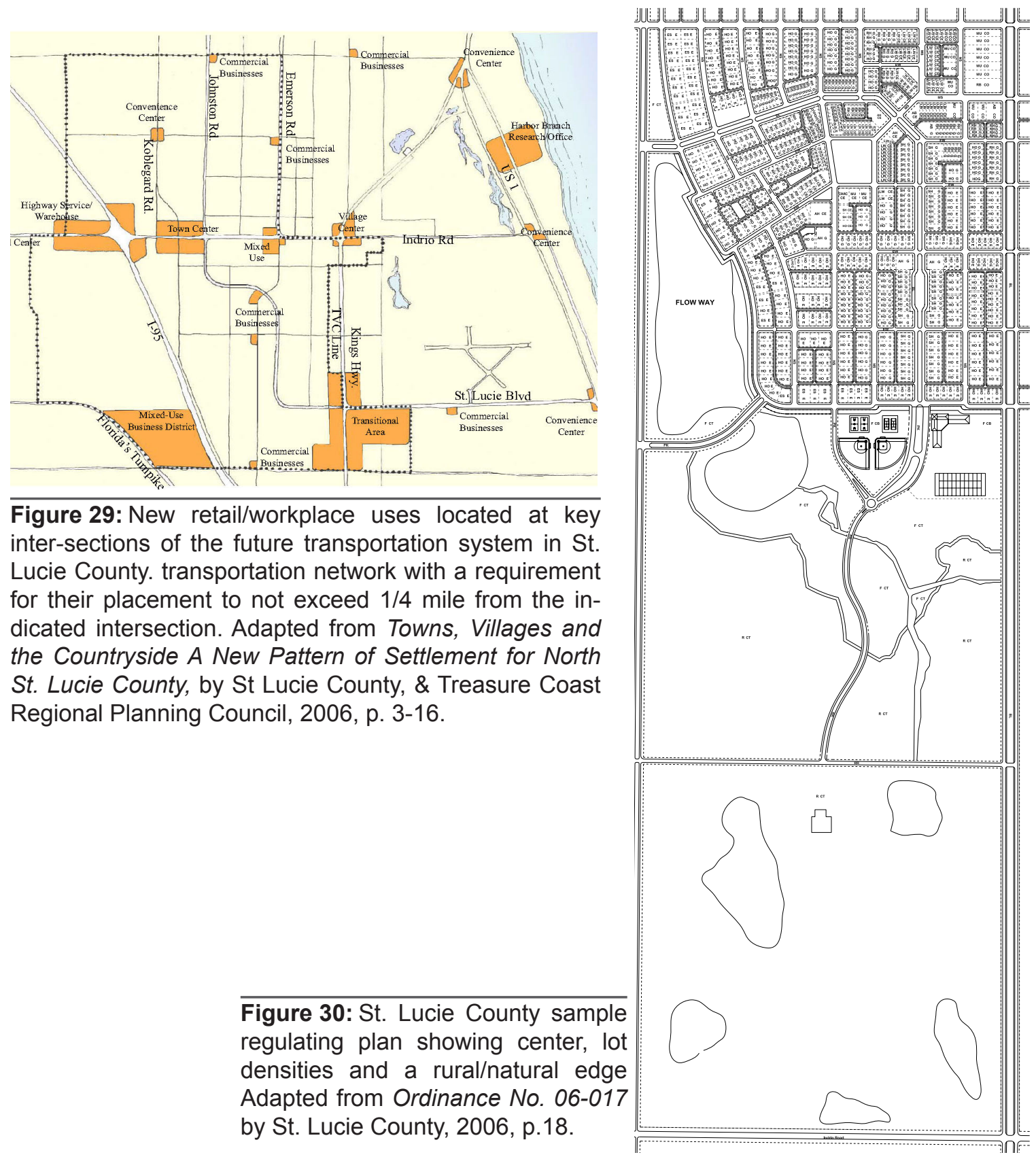


\section{Walkability Principle}

Considering the $40 \%$ required open space and rural area within a planned town or village, the proposed towns are of about a quarter mile radius, with an area of 625 and 225 acres that lies within .5 and .3 mile radii. This is typical of traditional development patterns laid out by DPZ. There is also adequate discussion of the 5 minute walk (the amount of time a pedestrian walks a .25 mile) in the Master Plan.

The code addresses most walkability parameters quite well, including adequate infrastructure to facilitate walking. Just like other codes, many requirements for density are addressed indirectly through provisions of spaces for higher amount of dwelling units, office, and retail/commercial per unit of area. Such parameters however would require population, employment and demographic studies to more accurate determine the needs of each community.

Walkability parameters of density, diversity, design, destinations, and distance were evaluated using the criteria shown on Table 5. Table 15 presents the evaluation of Walkability parameters within the 5Ds for the Benicia, CA Downtown Mixed-Use Master Plan:

\section{Table 15: Evaluation of Walkability parameters within the 5Ds: St. Lucie County, Florida} Towns, Villages and Countryside (TVC) Overlay Form-Based Code

\begin{tabular}{|c|c|c|c|}
\hline & D1_DENSITY & \multicolumn{2}{|c|}{$\begin{array}{l}\text { St Lucie } \\
\text { County FL }\end{array}$} \\
\hline & $\begin{array}{l}\text { D1 TOTAL } \\
\text { MIN-MAX RANGE: } 8-40\end{array}$ & \multicolumn{2}{|l|}{21} \\
\hline \# & Employment & 4 & \\
\hline 1 & Employment/job density & acc & 3 \\
\hline \multirow[t]{2}{*}{2} & Jobs-housing ratio/balance & $\mathrm{nr}$ & 1 \\
\hline & Population & 6 & \\
\hline
\end{tabular}




\begin{tabular}{|c|c|c|c|}
\hline 3 & Population per square unit of area, & acc & 3 \\
\hline \multirow[t]{2}{*}{4} & Dwelling units per square unit of area, & acc & 3 \\
\hline & Buildings & 6 & \\
\hline 5 & Building floor area per square unit of area & acc & 3 \\
\hline \multirow[t]{2}{*}{6} & Measure of enclosure based on building concentrations and height. & acc & 3 \\
\hline & Attractions/Destinations & 5 & \\
\hline 7 & $\begin{array}{l}\text { Large number of destinations/ attractions/amenities close together so } \\
\text { that you can run several errands in a single trip on foot. }\end{array}$ & acc & 3 \\
\hline 8 & Number of transit stops per unit area. & dis & 2 \\
\hline & D2_DIVERSITY & \multicolumn{2}{|c|}{$\begin{array}{l}\text { St Lucie } \\
\text { County, FL }\end{array}$} \\
\hline & $\begin{array}{l}\text { D2 TOTAL } \\
\text { MIN-MAX RANGE: } 6-30\end{array}$ & \multicolumn{2}{|l|}{23} \\
\hline & Employment & 3 & \\
\hline \multirow[t]{2}{*}{1} & Diversity of Employment & acc & 3 \\
\hline & Land Uses & 14 & \\
\hline 2 & $\begin{array}{l}\text { Number of different land uses in a given area/Degree to which different } \\
\text { land uses are represented in a given area/Floor area of different land } \\
\text { uses in a given area, }\end{array}$ & add & 4 \\
\hline \multirow[t]{2}{*}{3} & Land use mix & yes & 5 \\
\hline & Housing & 5 & \\
\hline \multirow[t]{2}{*}{4} & Diversity of housing options & yes & 5 \\
\hline & Destinations & 6 & \\
\hline 5 & $\begin{array}{l}\text { Diversity and mix of places to go - this includes parks, restaurants, } \\
\text { shops, trails, etc. providing enough diversity so that people have the } \\
\text { opportunity to fulfill at least some of their daily and weekly needs (work- } \\
\text { places, corner stores/markets, schools, restaurants, retail, public spaces, } \\
\text { parks, transit stops, and culture such as museums and music venues. }\end{array}$ & yes & 5 \\
\hline \multirow[t]{4}{*}{6} & $\begin{array}{l}\text { Percentage of residents within walking distance of defined diverse uses } \\
\text { that provide a measure of mixed-used development. }\end{array}$ & $\mathrm{nr}$ & 1 \\
\hline & D3_DESIGN & \multicolumn{2}{|c|}{$\begin{array}{l}\text { St Lucie } \\
\text { County, FL }\end{array}$} \\
\hline & $\begin{array}{l}\text { D3 TOTAL } \\
\text { MIN-MAX RANGE: } 16-80\end{array}$ & \multicolumn{2}{|l|}{61} \\
\hline & Neighborhood-level connectivity & 15 & \\
\hline 1 & Intersection density, (number of intersections per square unit of area) & yes & 5 \\
\hline 2 & Absence of barriers such as six lane roads. & yes & 5 \\
\hline \multirow[t]{2}{*}{3} & $\begin{array}{l}\text { A center: Walkable neighborhoods have a center, whether it's a main } \\
\text { street or a public space. }\end{array}$ & yes & 5 \\
\hline & Path-trail connectivity & 6 & \\
\hline 4 & Trail availability per 1,000 residents, & dis & 2 \\
\hline 5 & Bicycle path availability per 100 residents, & dis & 2 \\
\hline
\end{tabular}




\begin{tabular}{|c|c|c|c|}
\hline \multirow[t]{2}{*}{6} & Path/trail connectivity, internal and with street network. & dis & 2 \\
\hline & Street and sidewalk level pedestrian environment & 15 & \\
\hline 7 & Street trees, & $\mathrm{nr}$ & 1 \\
\hline 8 & Street widths, & yes & 5 \\
\hline 9 & Sidewalk qualities & $\mathrm{nr}$ & 1 \\
\hline 10 & Form as a measure of streetscape continuity (empty lots, blank walls) & yes & 5 \\
\hline \multirow[t]{2}{*}{11} & $\begin{array}{l}\text { Other qualities that distinguish walkable environments creating complete } \\
\text { streets designed for bicyclists, pedestrians, and transit. }\end{array}$ & add & 3 \\
\hline & Building level pedestrian adaptations & 25 & \\
\hline 12 & Buildings are close to the street & yes & 5 \\
\hline 13 & Building entrances are oriented to the street & yes & 5 \\
\hline 14 & Parking lots are relegated to the back & yes & 5 \\
\hline 15 & Stores at a reasonable square footage for small towns & yes & 5 \\
\hline \multirow[t]{4}{*}{16} & Building transparency & yes & 5 \\
\hline & D4_DESTINATIONS/ACCESS & \multicolumn{2}{|c|}{$\begin{array}{l}\text { St Lucie } \\
\text { County, FL }\end{array}$} \\
\hline & $\begin{array}{l}\text { D4 TOTAL } \\
\text { MIN-MAX RANGE: 21-105 }\end{array}$ & \multicolumn{2}{|l|}{80} \\
\hline & Places to go & 16 & \\
\hline 1 & $\begin{array}{l}\text { The sum of retail and businesses including recreation and schools within } \\
800 \text { meters or } .5 \text { miles. }\end{array}$ & add & 4 \\
\hline 2 & Presence of places to go that provide services to residents. & acc & 3 \\
\hline 3 & Presence of places to go open for business & $\mathrm{nr}$ & 1 \\
\hline 4 & Ease of access to destinations within a given distance: & & \\
\hline 5 & Parks and public spaces & add & 4 \\
\hline \multirow[t]{3}{*}{6} & $\begin{array}{l}\text { Recreational facilities such as gym/fitness facilities, and other recreation- } \\
\text { al uses }\end{array}$ & add & 4 \\
\hline & Infrastructure & 64 & \\
\hline & Adequate infrastructure to facilitate walking, such as: & 48 & \\
\hline 7 & Sidewalk continuity/coverage & yes & 5 \\
\hline 8 & Comfortable sidewalks & yes & 5 \\
\hline 9 & Curbcuts, & yes & 5 \\
\hline 10 & Street furniture & yes & 5 \\
\hline 11 & Bike racks, & yes & 5 \\
\hline 12 & Pedestrian friendly intersections. & yes & 5 \\
\hline 13 & Traffic signals, & yes & 5 \\
\hline 14 & Speed limits, & add & 4 \\
\hline 15 & Traffic calming, & add & 4 \\
\hline \multirow[t]{2}{*}{16} & Other traffic measures & yes & 5 \\
\hline & Pleasant environment & 16 & \\
\hline
\end{tabular}




\begin{tabular}{|l|l|l|l|}
\hline 17 & A pleasant environment to walk with attractive features & add & 4 \\
\hline 18 & Outdoor dining, & acc & 3 \\
\hline 19 & Personal Safety such as absence of litter, graffiti, windows with bars, & $\mathrm{nr}$ & 1 \\
\hline 20 & Open Views, & add & 4 \\
\hline 21 & Maintenance. & add & 4 \\
\hline & & & \\
\hline & D5_DISTANCE & $\begin{array}{l}\text { St Lucie } \\
\text { County, FL }\end{array}$ \\
\hline & $\begin{array}{l}\text { D5 TOTAL } \\
\text { MIN-MAX RANGE: 8-40 }\end{array}$ & 40 \\
\hline & 5 or 10 minute walk proximity & & \\
\hline 1 & $\begin{array}{l}1 / 4 \text { to } 1 / 5 \text { mile radius from home to key destinations or up to 1/2 mile ra- } \\
\text { dius segments. }\end{array}$ & yes & 5 \\
\hline 2 & Average distance to the downtown, & Wk & 5 \\
\hline 3 & Average distance or time to nearest attractions within a given area & Wk & 5 \\
\hline 4 & Average distance or travel time from home to the nearest store. & Wk & 5 \\
\hline 5 & Average distance to jobs within a given area & Wk & 5 \\
\hline 6 & Average distance to nearest jobs, & Wk & 5 \\
\hline 7 & Average distance to the nearest transit stop or station, & Wk & 5 \\
\hline 8 & Average distance between transit stops & Wk & 5 \\
\hline
\end{tabular}




\section{Project Description}

The Lee County Compact Communities Code is part of the effort to protect the local shallow aquifers, reduce population capacity, and plan for land uses compatible with maintaining surface and groundwater levels at historic levels in Lee County, Florida. The code provides development regulations for future walkable communities and mixed-use centers. For any new development, the code requires submittal of regulating plans that identify transects of a specific urban intensity, along with street types and lot types relevant to each transect. Figure 31 shows Southeast Lee County with a significant amount of showing high amount of rural and natural areas.

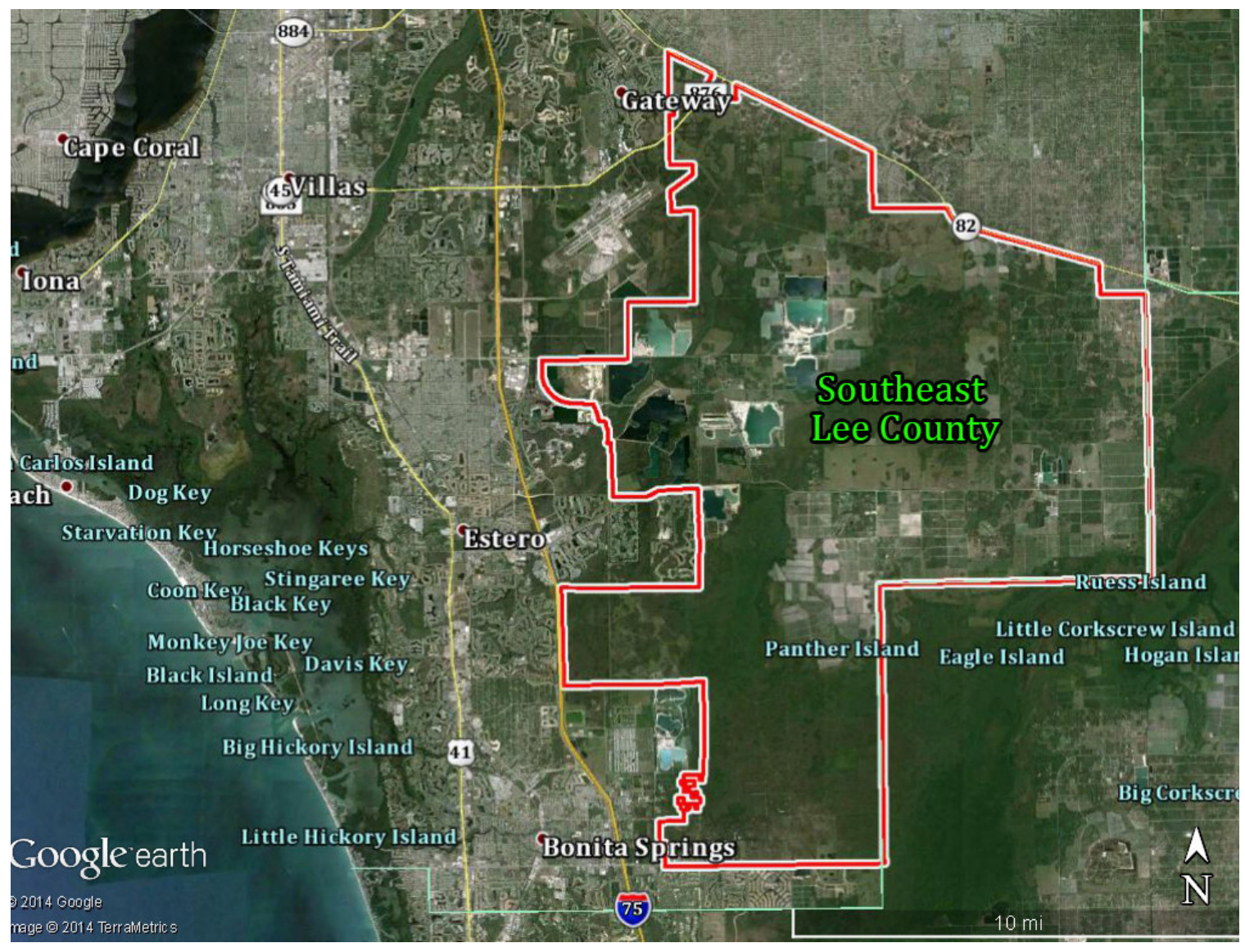

Figure 31: Southeast Lee County (outline in red) showing high amount of rural and natural areas in comparison to the urbanized western Lee County. Adapted from Google Earth imagery. 
The code describes detailed requirements for transects, streets and lots and requires the presence of a center within a walking distance of primarily residential neighborhoods. However although 'walking distance' is repeatedly mentioned in the code, a reference, or requirement for implementation of a specific walkable radius in future communities is omitted. The code mentions the 1/4 mile walking distance only in the case of pre-existing centers but requires new development, if devoid of a center, to be within a 1/4-mile distance of pre-existing centers.

\section{Neighborhood Principle}

Although the code intends to create walkable neighborhoods with an identifiable center and edge, a specific requirement for a quarter mile or other walkable radius is included as

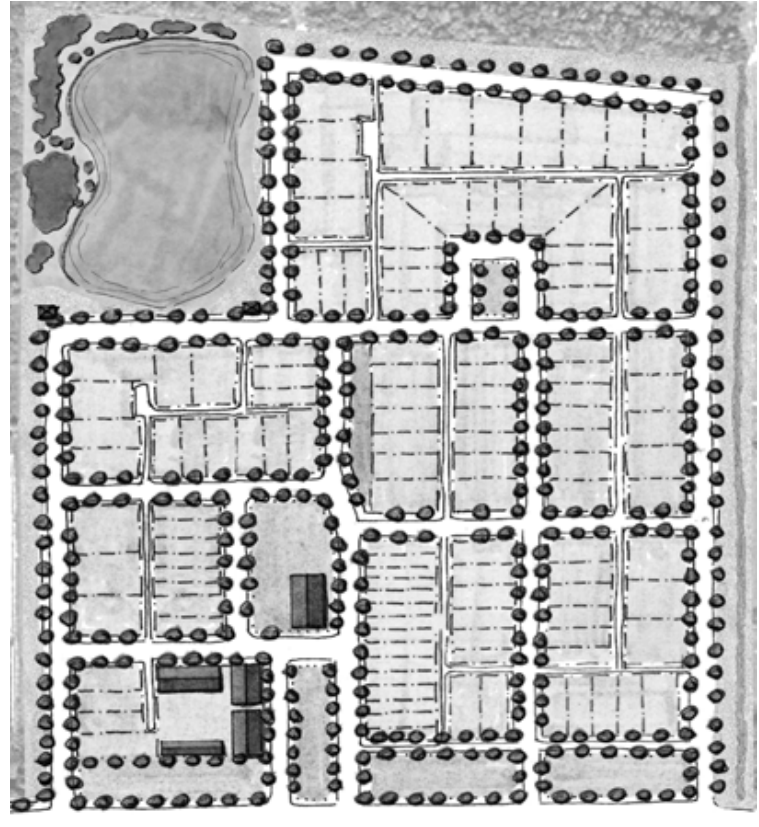

Figure 32: Lee County, FL Compact Communities Code sample illustrative plan. From Lee County Land Development Code (LDC), Chapter 32 - COMPACT COMMUNITIES by Lee County, FL, 2014, p. 32-34. a reminder in the conceptual regulating plans only. Illustrative plans are stated as non-binding but they are required to follow the regulating plan directions. There is a special transect zone labeled 'edge' required for development zones adjacent to existing low intensity development and natural areas. The 'edge' transect zone corresponds to some extent to the requirement of a neighborhood with an identifiable edge. There is no clear discussion in the code however 
of any other options in identifying edges in neighborhoods such as natural areas or special treatments for streets. Figure 32 shows a Compact Communities Code sample illustrative plan, Figure 33 shows a sample regulating plan and Figure 34 a Compact Communities Code conceptual regulating plan with 5-minute walk indicator scale on the lower right. Table 16 presents the evaluation of Neighborhood parameters for the Lee County, FL Compact Communities Code. The code is rated .5 for the indefatigable edge due to the

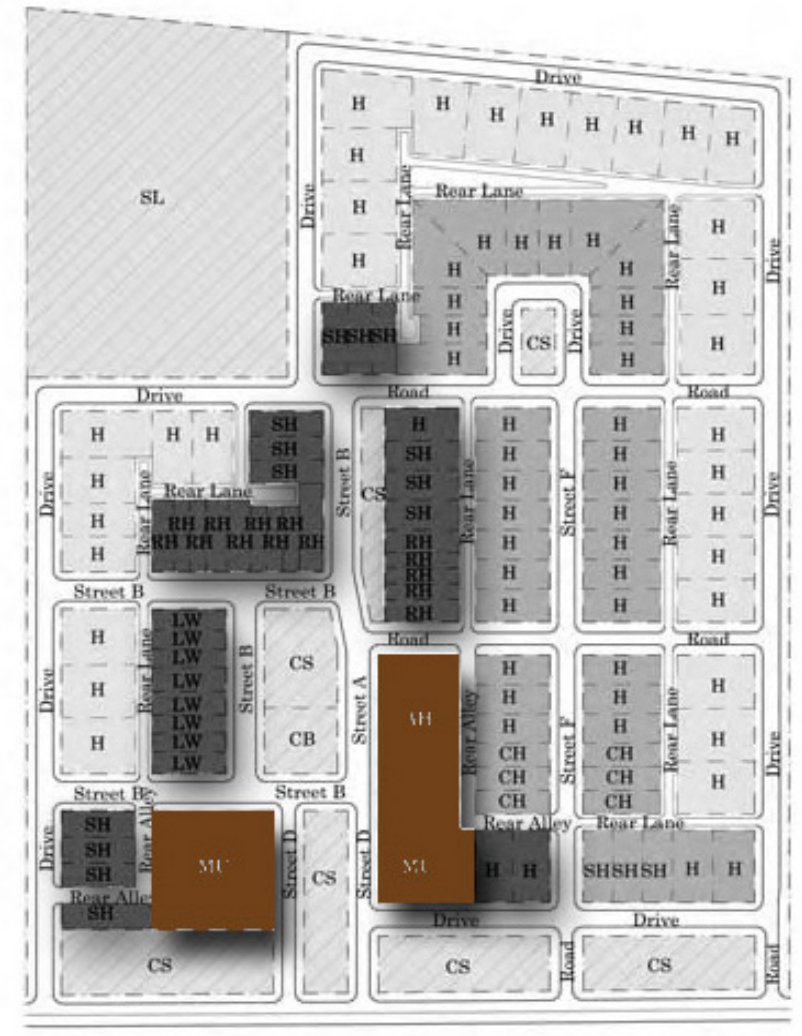
ransect Legend Lot Types

\begin{tabular}{lll}
\hline - Edge & MU - Mixed Use Lot & SH - Sideyard Lot \\
- General & AH - Apartment Lot & CH - Cottage Lot \\
- Center & LW - Live/Work Lot & CB - Civic Buildin \\
- Core & RH - Rowhouse Lot & CS - Civic Space L \\
- Civic & H - House Lot & SL - Stormwater L
\end{tabular}

Figure 33: Lee County, FL Compact Communities Code sample regulating plan. Adapted from Lee County Land Development Code (LDC), Chapter 32 - COMPACT COMMUNITIES by Lee County, FL, 2014, p. 3-34. 
inclusion of a requirement for an edge transect zone. St Lucie County, with the ample open space around the communities seems to address the concept more effectively. Exploration of the type of edges that are significant in community design seems important to clarify the concept.

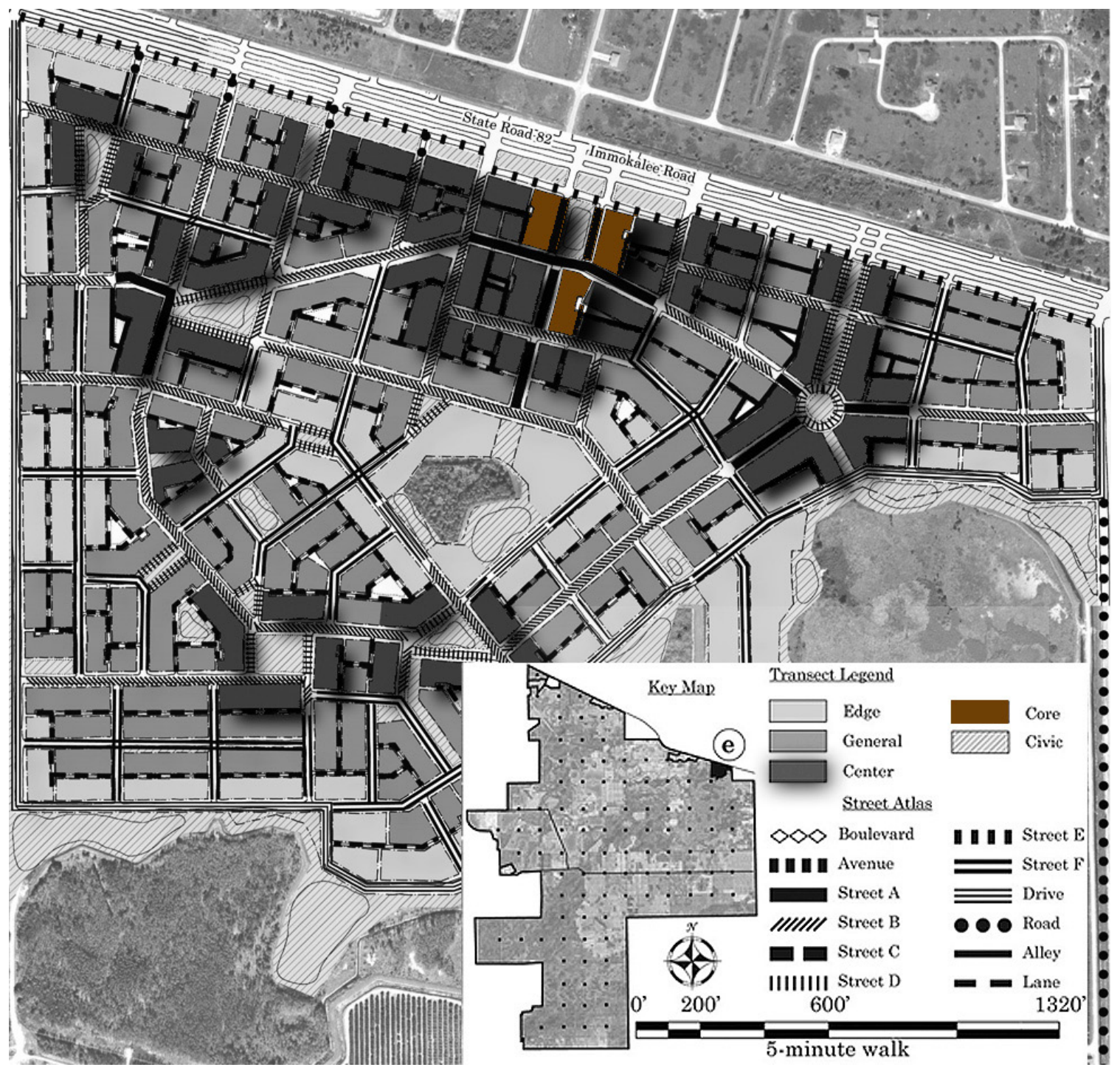

Figure 34: Lee County, FL. Compact Communities Code conceptual regulating plan with 5-minute walk indicator scale on the lower right. Adapted from Lee County Land Development Code (LDC), Chapter 32 - COMPACT COMMUNITIES by Lee County, FL, 2014, p. 32-49. 


\begin{tabular}{|c|c|c|}
\hline .25 mile or similar radius or a 5 min walk neighborhood & yes & 1 \\
\hline Center with civic and/or mixed uses in regulating plan & yes & 1 \\
\hline Identifiable edge: discussion, mention, or delineations in any plan & partly & .5 \\
\hline $\begin{array}{l}\text { Notes: } \\
\text { - Although the requirement for walkable developments is prevalent in the doc- } \\
\text { ument, only conceptual regulating plans address measurements for walk- } \\
\text { able distances. The sample regulating plan and the coding standards do not } \\
\text { specify such distances except for new development adjacent to pre-existing } \\
\text { centers. The impact to walkability of such a limited reference is unclear. } \\
\text { - Edges were addressed only as part of the 'Edge Transect' required to be } \\
\text { same intensity as adjacent development or be next to natural areas. }\end{array}$ & Total: & 2.5 \\
\hline
\end{tabular}

\section{Proximity to Daily Needs Principle}

The basic principles and conventions of the code "include an identifiable center and edge, walkable size, mix of land uses and housing types with opportunities for shopping and workplaces close to home, an integrated network of walkable streets, and the reservation of special sites for civic purposes" (Lee County, FL, 2014, p. 32-51). Table 17 presents the evaluation of Neighborhood parameters for Lee County, FL Compact Communities Code:

\begin{tabular}{|l|l|l|}
\hline $\begin{array}{l}\text { Table 17: Proximity to Daily Needs Principle: Lee County, FL Compact Communities } \\
\text { Code }\end{array}$ \\
\hline Residential within .25 mile radius from mixed use/retail/commercial areas & yes & 1 \\
\hline Mixed use, retail, commercial, office development presence in illustrative plan & yes & 1 \\
\hline Mixed use, retail, commercial, office development presence in regulating plan & yes & 1 \\
\hline Mixed use, retail, commercial, office development presence in the zoning code & yes & 1 \\
\hline A diversity of building types in illustrative plan & yes & 1 \\
\hline A diversity of building types in regulating plan & yes & 1 \\
\hline A diversity of building types in the zoning code & yes & 1 \\
\hline Presence of various building types within the .25 mile radius neighborhood & yes & 1 \\
\hline $\begin{array}{l}\text { Notes: } \\
\text { Instead of a .25 mile walkable radius, the code requires a center within "a walk- } \\
\text { ing distance" of any residential areas. The conceptual regulating plan is the plan } \\
\text { with a graphic measure of the walking distance as the 5 min walk. }\end{array}$ & & 8 \\
\hline
\end{tabular}




\section{Walkability Principle}

The standards and regulations for the Compact Communities Code provide for transects, streets, and building lots in addition to civic space lots, regulating plans and stormwater management. The Walkability principle is reflected in the illustrative plan by the depiction of walkable environments while the regulating plan presents a .25 mile radius, or a 5 -min walking distance along with existing or proposed intersection density.

Other walkability parameters can appear from the illustrative and regulating plans to the zoning standards and regulations. As in some other case studies, Destination/Accessibility parameters of adequate infrastructure to facilitate walking such as traffic calming, or bike racks are not regulated by the code.

Walkability parameters of density, diversity, design, destinations, and distance were evaluated using the criteria shown on Table 5. Table 18 presents the evaluation of Walkability parameters within the 5Ds for Lee County, FL Compact Communities Code:

\begin{tabular}{l}
\hline $\begin{array}{l}\text { Table 18: Evaluation of Walkability parameters within the 5Ds: Lee County, FL Compact } \\
\text { Communities Code }\end{array}$ \\
\begin{tabular}{|l|l|l|l|}
\hline & D1_DENSITY & \multicolumn{2}{l|}{ Lee County, FL } \\
\hline & $\begin{array}{l}|l| \\
\text { D1 TOTAL } \\
\text { MIN-MAX RANGE: 8-40 }\end{array}$ & 21 \\
\hline$\#$ & Employment & 4 & \\
\hline 1 & Employment/job density & acc & 3 \\
\hline 2 & Jobs-housing ratio/balance & $\mathrm{nr}$ & 1 \\
\hline & Population & 6 & \\
\hline 3 & Population per square unit of area, & acc & 3 \\
\hline 4 & Dwelling units per square unit of area, & acc & 3 \\
\hline & Buildings & 6 & \\
\hline 5 & Building floor area per square unit of area & acc & 3 \\
\hline & & & \\
\hline
\end{tabular}
\end{tabular}




\begin{tabular}{|c|c|c|c|}
\hline \multirow[t]{2}{*}{6} & Measure of enclosure based on building concentrations and height. & acc & 3 \\
\hline & Attractions/Destinations & 5 & \\
\hline 7 & $\begin{array}{l}\text { Large number of destinations/ attractions/amenities close together so } \\
\text { that you can run several errands in a single trip on foot. }\end{array}$ & add & 4 \\
\hline \multirow[t]{4}{*}{8} & Number of transit stops per unit area. & $\mathrm{nr}$ & 1 \\
\hline & D2_DIVERSITY & \multicolumn{2}{|c|}{ Lee County, FL } \\
\hline & D2 TOTAL & \multicolumn{2}{|l|}{17} \\
\hline & Employment & 3 & \\
\hline \multirow[t]{2}{*}{1} & Diversity of Employment & acc & 3 \\
\hline & Land Uses & 12 & \\
\hline 2 & $\begin{array}{l}\text { Number of different land uses in a given area/Degree to which different } \\
\text { land uses are represented in a given area/Floor area of different land } \\
\text { uses in a given area, }\end{array}$ & add & 4 \\
\hline \multirow[t]{2}{*}{3} & Land use mix & add & 4 \\
\hline & Housing & 4 & \\
\hline \multirow[t]{2}{*}{4} & Diversity of housing options & add & 4 \\
\hline & Destinations & 2 & \\
\hline 5 & $\begin{array}{l}\text { Diversity and mix of places to go - this includes parks, restaurants, } \\
\text { shops, trails, etc. providing enough diversity so that people have the } \\
\text { opportunity to fulfill at least some of their daily and weekly needs } \\
\text { (workplaces, corner stores/markets, schools, restaurants, retail, public } \\
\text { spaces, parks, transit stops, and culture such as museums and music } \\
\text { venues. }\end{array}$ & acc & 1 \\
\hline \multirow[t]{4}{*}{6} & $\begin{array}{l}\text { Percentage of residents within walking distance of defined diverse } \\
\text { uses that provide a measure of mixed-used development. }\end{array}$ & $\mathrm{nr}$ & 1 \\
\hline & D3_DESIGN & \multicolumn{2}{|c|}{ Lee County, FL } \\
\hline & $\begin{array}{l}\text { D3 TOTAL } \\
\text { MIN-MAX RANGE: } 16-80\end{array}$ & \multicolumn{2}{|l|}{63} \\
\hline & Neighborhood-level connectivity & 14 & \\
\hline 1 & Intersection density, (number of intersections per square unit of area) & add & 4 \\
\hline 2 & Absence of barriers such as six lane roads. & yes & 5 \\
\hline \multirow[t]{2}{*}{3} & $\begin{array}{l}\text { A center: Walkable neighborhoods have a center, whether it's a main } \\
\text { street or a public space. }\end{array}$ & yes & 5 \\
\hline & Path-trail connectivity & 3 & \\
\hline 4 & Trail availability per 1,000 residents, & $\mathrm{nr}$ & 1 \\
\hline 5 & Bicycle path availability per 100 residents, & dis & 1 \\
\hline \multirow[t]{2}{*}{6} & Path/trail connectivity, internal and with street network. & $\mathrm{nr}$ & 1 \\
\hline & Street and sidewalk level pedestrian environment & 21 & \\
\hline 7 & Street trees, & yes & 5 \\
\hline 8 & Street widths, & yes & 5 \\
\hline
\end{tabular}




\begin{tabular}{|c|c|c|c|}
\hline 9 & Sidewalk qualities & yes & 5 \\
\hline 10 & Form as a measure of streetscape continuity (empty lots, blank walls) & $\mathrm{nr}$ & 1 \\
\hline \multirow[t]{2}{*}{11} & $\begin{array}{l}\text { Other qualities that distinguish walkable environments creating com- } \\
\text { plete streets designed for bicyclists, pedestrians, and transit. }\end{array}$ & yes & 5 \\
\hline & Building level pedestrian adaptations & 25 & \\
\hline 12 & Buildings are close to the street & yes & 5 \\
\hline 13 & Building entrances are oriented to the street & yes & 5 \\
\hline 14 & Parking lots are relegated to the back & yes & 5 \\
\hline 15 & Stores at a reasonable square footage for small towns & yes & 5 \\
\hline \multirow[t]{4}{*}{16} & Building transparency & yes & 5 \\
\hline & D4_DESTINATIONS/ACCESS & \multicolumn{2}{|c|}{ Lee County, FL } \\
\hline & $\begin{array}{l}\text { D4 TOTAL } \\
\text { MIN-MAX RANGE: } 21-105\end{array}$ & \multicolumn{2}{|l|}{63} \\
\hline & Places to go & 19 & \\
\hline 1 & $\begin{array}{l}\text { The sum of retail and businesses including recreation and schools } \\
\text { within } 800 \text { meters or } .5 \text { miles. }\end{array}$ & acc & 3 \\
\hline 2 & Presence of places to go that provide services to residents. & acc & 3 \\
\hline 3 & Presence of places to go open for business & $\mathrm{nr}$ & 1 \\
\hline 4 & Ease of access to destinations within a given distance: & add & 4 \\
\hline 5 & Parks and public spaces & add & 4 \\
\hline \multirow[t]{3}{*}{6} & $\begin{array}{l}\text { Recreational facilities such as gym/fitness facilities, and other recre- } \\
\text { ational uses }\end{array}$ & add & 4 \\
\hline & Infrastructure & 44 & \\
\hline & Adequate infrastructure to facilitate walking, such as: & 30 & \\
\hline 7 & Sidewalk continuity/coverage & yes & 5 \\
\hline 8 & Comfortable sidewalks & yes & 5 \\
\hline 9 & Curbcuts, & yes & 5 \\
\hline 10 & Street furniture & $\mathrm{nr}$ & 1 \\
\hline 11 & Bike racks, & $\mathrm{nr}$ & 1 \\
\hline 12 & Pedestrian friendly intersections. & $\mathrm{nr}$ & 1 \\
\hline 13 & Traffic signals, & $\mathrm{nr}$ & 1 \\
\hline 14 & Speed limits, & yes & 5 \\
\hline 15 & Traffic calming, & $\mathrm{nr}$ & 1 \\
\hline \multirow[t]{2}{*}{16} & Other traffic measures & yes & 5 \\
\hline & Pleasant environment & 14 & \\
\hline 17 & A pleasant environment to walk with attractive features & add & 4 \\
\hline 18 & Outdoor dining, & acc & 3 \\
\hline 19 & Personal Safety such as absence of litter, graffiti, windows with bars, & $\mathrm{nr}$ & 1 \\
\hline 20 & Open Views, & $\mathrm{nr}$ & 1 \\
\hline 21 & Maintenance. & yes & 5 \\
\hline
\end{tabular}




\begin{tabular}{|l|l|l|l|}
\hline & \multicolumn{2}{|l|}{} & \multicolumn{2}{|l|}{} \\
\hline & D5_DISTANCE & \multicolumn{2}{l|}{ Lee County, FL } \\
\hline & MIN-MAX RANGE: 8-40 & 27 \\
\hline & $\begin{array}{l}5 \text { or } 10 \text { minute walk proximity } \\
1 / 4 \text { to } 1 / 5 \text { mile radius from home to key destinations or up to } 1 / 2 \text { mile } \\
\text { radius segments. }\end{array}$ & add & 4 \\
\hline 2 & Average distance to the downtown, & add & 4 \\
\hline 3 & Average distance or time to nearest attractions within a given area & add & 4 \\
\hline 4 & Average distance or travel time from home to the nearest store. & acc & 3 \\
\hline 5 & Average distance to jobs within a given area & acc & 3 \\
\hline 6 & Average distance to nearest jobs, & acc & 3 \\
\hline 7 & Average distance to the nearest transit stop or station, & dis & 2 \\
\hline 8 & Average distance between transit stops & $\mathrm{nr}$ & 4 \\
\hline
\end{tabular}




\subsubsection{The Cincinnati Form-Based Code (2014 Driehaus Honorable Mention)}

\section{Project Description}

\section{Honors}

The city-wide Cincinnati Form-Based Code won an Driehaus Honorable Mention in the 2014 and encourages neighborhood-based planning, urban infill, and the retrofit of neighborhood fabric and existing buildings. This process is a new model for cities looking to move to form-based regulations The code did not receive a full Driehaus Award due to lack of predictable street-space character (Form-Based Codes Institute, 2014b). Such a deficiency is expected to appear in the walkability parameter checklist in this document

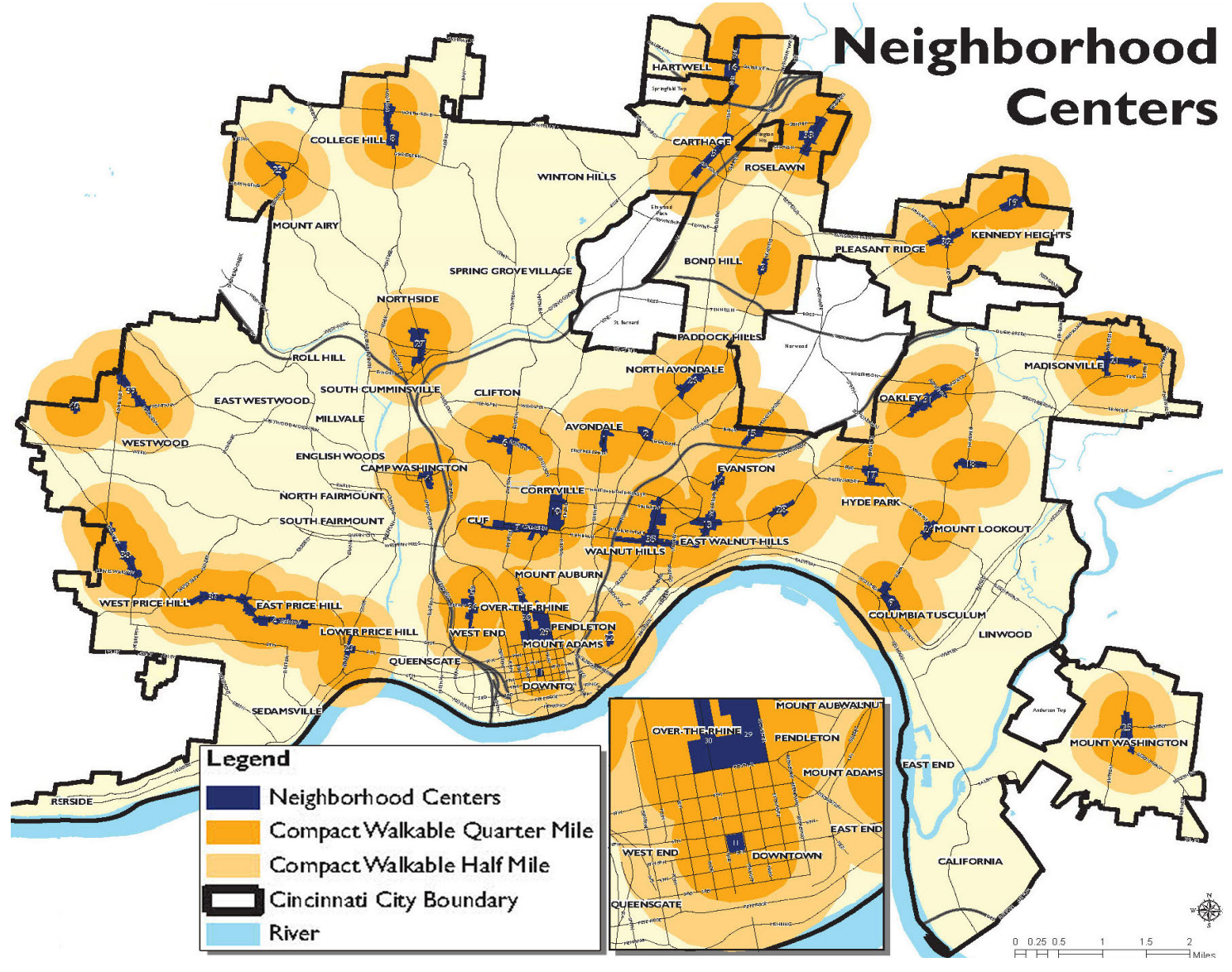

Figure 35: Identified and delineated .25 and .5 mile walkable neighborhoods with neighborhood centers as part of the Cincinnati Comprehensive Plan update and form-based code efforts. Adapted from Download Plan Cincinnati. Plancincinnati.org. by the City of Cincinnati, 2013, p. 86. 
under the Walkability Principle. The Cincinnati Form-Based Code however, won the Grand Prize for Best Planning Tool or Process at the Congress for New Urbanism's Annual Charter Awards in Buffalo, N.Y., during CNU's annual Congress, in June of 2014.

\section{Plan Cincinnati}

The form-based code implements the principles and vision of "Plan Cincinnati," the Comprehensive Plan for the City of Cincinnati, adopted in 2012. Plan Cincinnati, received the 2014 Daniel Burnham Award for a Comprehensive Plan from the American Planning Association (APA). The Plan Cincinnati approach distinguishes between rural, drivable and walkable areas, delineates walkable neighborhoods and assigns urban intensity transects to each walkable neighborhood. All walkable neighborhoods have an identifiable center within a .25 mile and .5 mile depicted radius.

\section{The Form-Based Code}

“"The Cincinnati Form-Based Code The code establishes transect zones and specifies standards for transects, building types, frontage types, walkable neighborhoods, and thoroughfares. Additional standard sections regulate for hillside and historic districts, parking, and corner stores. One of the major contributions of the code is the walkable neighborhood standards that span across transects and specify allocation of transect zones, pedestrian sheds, neighborhood centers, thoroughfare connectivity, open space, and civic space standards. Standards and regulations are keyed to regulating plans, emphasize parameters for form with predictable physical outcomes and incorporate numerous clearly 
labeled, diagrams. The Cincinnati Form-Based Code is the result of a lengthy community input and participation process" (Form-Based Codes Institute, 2014b).

\section{Neighborhood Principle}

The Cincinnati Plan identifies within the City of Cincinnati, walkable neighborhoods revolving at .25 and .5 miles around an identified existing or proposed center (see Figure 35). Neighborhoods are categorized under a few character types repeatable throughout the city. Once the neighborhood is identified, transects are assigned as urban intensity zones to implement the vision of the Comprehensive Plan with zoning standards and regulations for every transect. Every delineated walkable neighborhood in the City is equipped with a regulating plan. Figure 36 shows a sample regulating plan for one of the selected walkable neighborhoods in Cincinnati. Table 19 presents the Neighborhood principle parameter evaluations for the Cincinnati Form-Based Code:

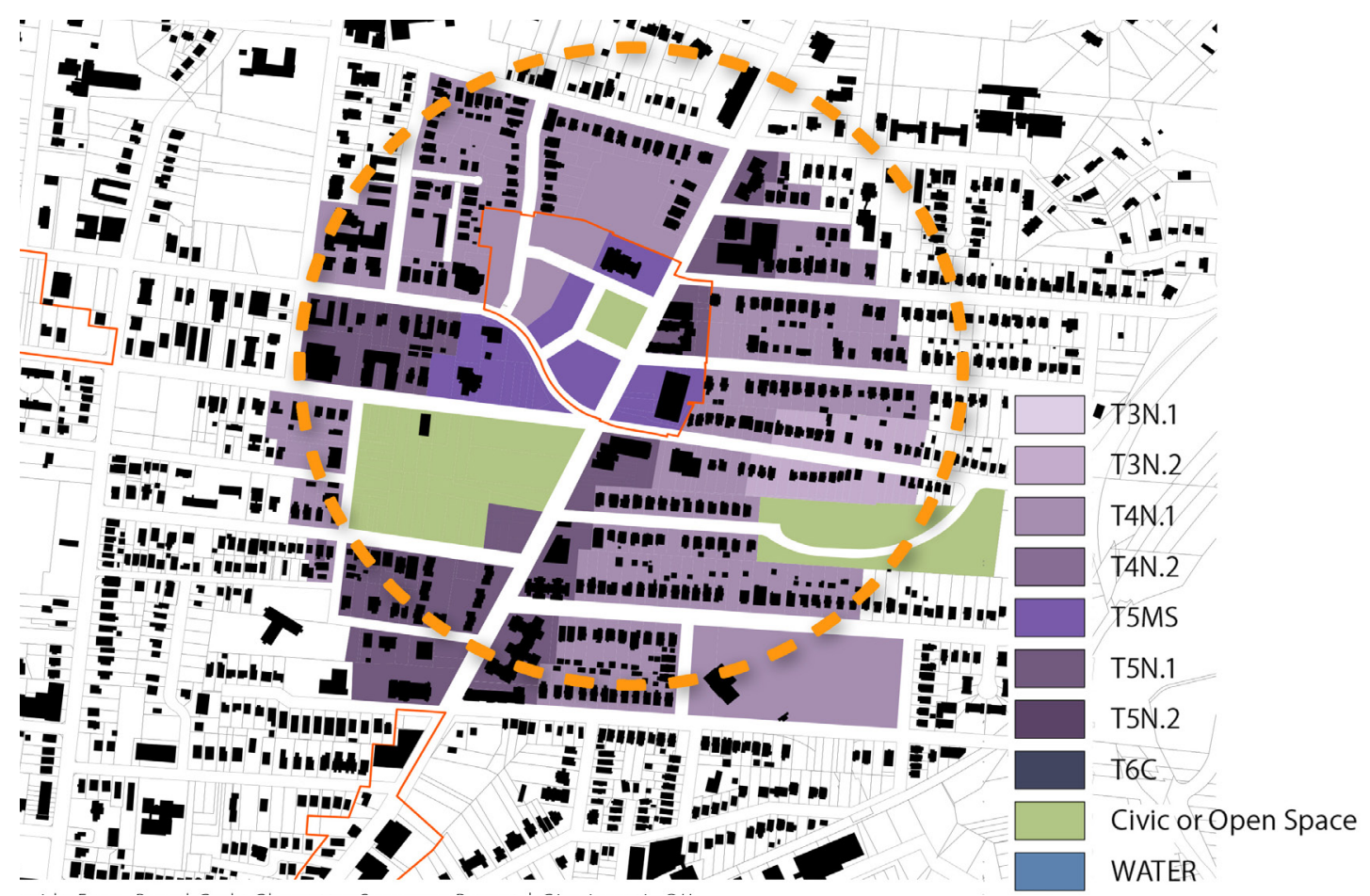

Figure 36: Sample Regulating Plan showing .25 mile radius superimposed over a neighborhood center and assigned transects. Adapted from Complete Neighborhoods, Citywide Form-Based Code Charrette: Summary Report, by the City of Cincinnati, OH \& Opticos Design, Inc., 2012, p. F.21. 


\begin{tabular}{|c|c|c|}
\hline 25 mile or similar radius or a 5 min walk neighborhood & yes & 1 \\
\hline Center with civic and/or mixed uses in regulating plan & yes & 1 \\
\hline Identifiable edge: discussion, mention, or delineations in any plan & no & 0 \\
\hline Notes & Total: & 2 \\
\hline
\end{tabular}

\section{Proximity to Daily Needs Principle}

The Cincinnati Plan identifies and delineates walkable neighborhoods and the form-based code is the instrument with the standards and guidelines to implement the vision of walkable neighborhoods. Proximity to daily needs is satisfied with the supply of proximate neighborhood centers with available retail and commercial uses and a diversity of building types or lots. Figure 37 shows the requirement of blocks to include a diversity of building types in the Cincinnati Code for T4 transects. Table 20 presents the Proximity to Daily Needs principle parameter evaluations for the Cincinnati Form-Based Code.

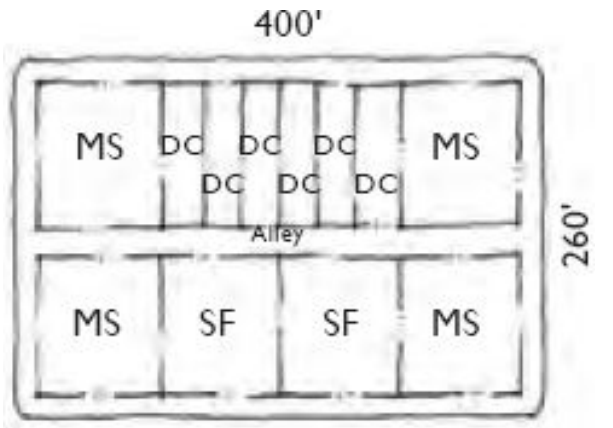

Figure 37: Example of blocks with a diversity of building types in the Cincinnati Code for T4 transects. Adapted from Final Draft of Cincinnati Form-Based Code - City Planning \& Buildings. Cincinnati-oh.gov., by the City of Cincinnati, 2014, p. 6-15.

\begin{tabular}{|l|l|l|}
\hline Table 20: Proximity to Daily Needs Principle: The Cincinnati Form-Based Code \\
\hline Residential within .25 mile radius from mixed use/retail/commercial areas & yes & 1 \\
\hline Mixed use, retail, commercial, office development presence in illustrative plan & yes & 1 \\
\hline Mixed use, retail, commercial, office development presence in regulating plan & yes & 1 \\
\hline Mixed use, retail, commercial, office development presence in the zoning code & yes & 1 \\
\hline A diversity of building types in illustrative plan & yes & 1 \\
\hline
\end{tabular}




\begin{tabular}{|l|l|l|}
\hline A diversity of building types in regulating plan & yes & 1 \\
\hline A diversity of building types in the zoning code & yes & 1 \\
\hline Presence of various building types within the .25 mile radius neighborhood & yes & 1 \\
\hline Notes: - & Total: & 8 \\
\hline
\end{tabular}

\section{Walkability Principle}

The Cincinnati Form-Based Code aims at the creation of walkable communities throughout the City. The planning approach is to identify the most walkable possible locations in the city and establish there walkable neighborhoods. First the .25 mile 5-minute radius is established followed by urban intensity transects and, finally, form-based code standards and regulations are set for each transect. To achieve a good land-use mix that facilitates walkability and proximity to daily needs, several building types are assigned in every transect and several transects are required for each walkable neighborhood. In addition, thoroughfare assembly standards and specifications provide a stronger control over street parameters such as curbs, lane width, medians and speed. Figure 38 shows thoroughfare assembly standards and specifications in the Cincinnati Form-Based Code for a commercial avenue and a street.

Walkability parameters of density, diversity, design, destinations, and distance were evaluated using the criteria shown on Table 5. Table 21 presents the evaluation of Walkability parameters within the 5Ds for the Cincinnati Form-Based Code. 


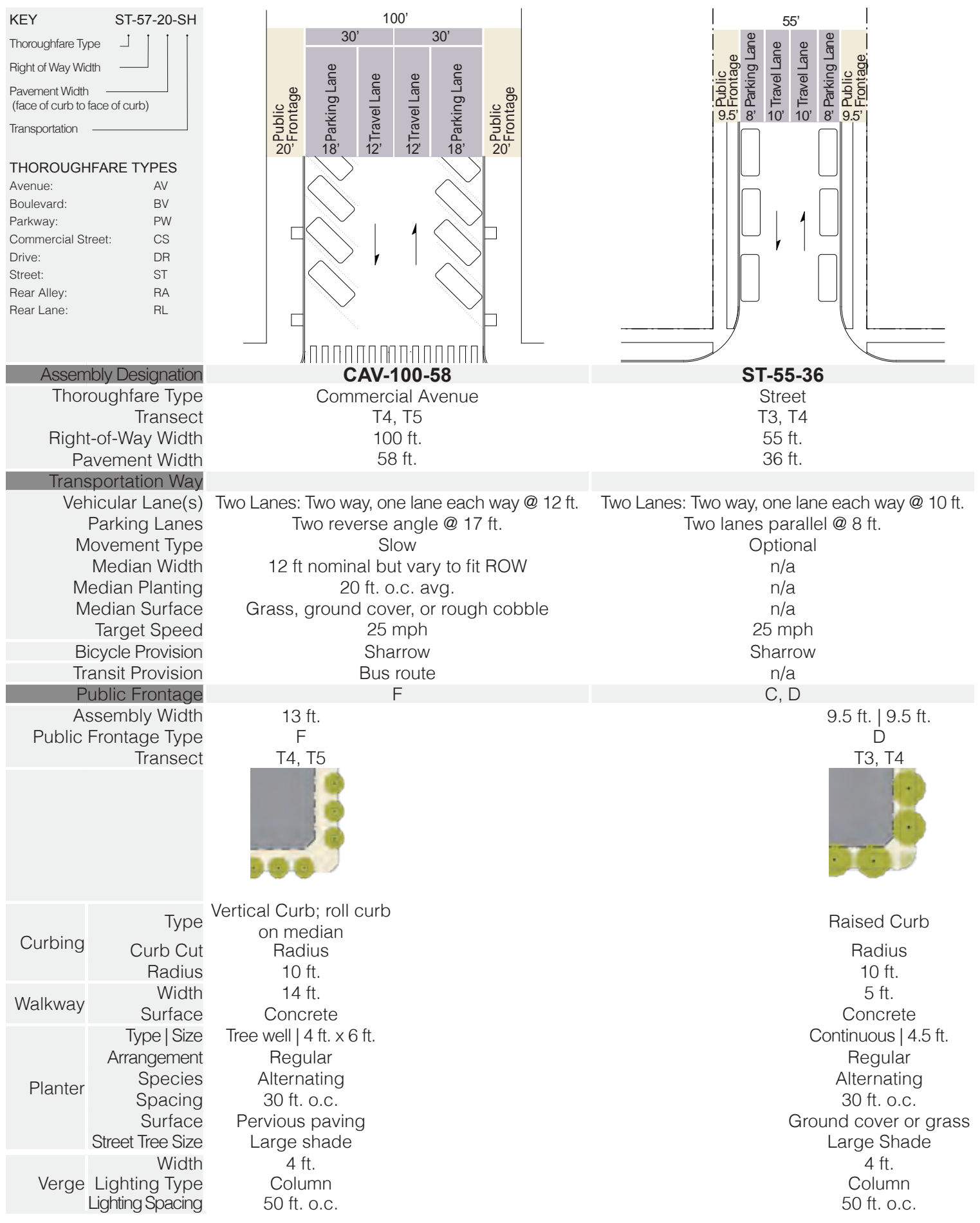

Figure 38: Thoroughfare assembly standards and specifications in the Cincinnati Form-Based Code. Adapted from Final Draft of Cincinnati Form-Based Code - City Planning \& Buildings. Cincinnati-oh.gov., by the City of Cincinnati, 2014, p. 7-14. 
Table 21: Evaluation of Walkability parameters within the 5Ds: The Cincinnati FormBased Code

\begin{tabular}{|c|c|c|c|}
\hline & D1_DENSITY & \multicolumn{2}{|c|}{ Cincinnati, $\mathrm{OH}$} \\
\hline & D1 TOTAL & \multicolumn{2}{|l|}{21} \\
\hline \# & Employment & 4 & \\
\hline 1 & Employment/job density & acc & 3 \\
\hline \multirow[t]{2}{*}{2} & Jobs-housing ratio/balance & $\mathrm{nr}$ & 1 \\
\hline & Population & 6 & \\
\hline 3 & Population per square unit of area, & acc & 3 \\
\hline \multirow[t]{2}{*}{4} & Dwelling units per square unit of area, & acc & 3 \\
\hline & Buildings & 6 & \\
\hline 5 & Building floor area per square unit of area & acc & 3 \\
\hline \multirow[t]{2}{*}{6} & Measure of enclosure based on building concentrations and height. & acc & 3 \\
\hline & Attractions/Destinations & 5 & \\
\hline 7 & $\begin{array}{l}\text { Large number of destinations/ attractions/amenities close together so } \\
\text { that you can run several errands in a single trip on foot. }\end{array}$ & add & 4 \\
\hline \multirow[t]{4}{*}{8} & Number of transit stops per unit area. & $\mathrm{nr}$ & 1 \\
\hline & D2_DIVERSITY & \multicolumn{2}{|c|}{ Cincinnati, $\mathrm{OH}$} \\
\hline & $\begin{array}{l}\text { D2 TOTAL } \\
\text { MIN-MAX RANGE: } 6-30\end{array}$ & \multicolumn{2}{|l|}{21} \\
\hline & Employment & 4 & \\
\hline \multirow[t]{2}{*}{1} & Diversity of Employment & add & 4 \\
\hline & Land Uses & 12 & \\
\hline 2 & $\begin{array}{l}\text { Number of different land uses in a given area/Degree to which differ- } \\
\text { ent land uses are represented in a given area/Floor area of different } \\
\text { land uses in a given area, }\end{array}$ & add & 4 \\
\hline \multirow[t]{2}{*}{3} & Land use mix & add & 4 \\
\hline & Housing & 4 & \\
\hline \multirow[t]{2}{*}{4} & Diversity of housing options & add & 4 \\
\hline & Destinations & 5 & \\
\hline 5 & $\begin{array}{l}\text { Diversity and mix of places to go - this includes parks, restaurants, } \\
\text { shops, trails, etc. providing enough diversity so that people have the } \\
\text { opportunity to fulfill at least some of their daily and weekly needs } \\
\text { (workplaces, corner stores/markets, schools, restaurants, retail, pub- } \\
\text { lic spaces, parks, transit stops, and culture such as museums and } \\
\text { music venues. }\end{array}$ & add & 4 \\
\hline \multirow[t]{2}{*}{6} & $\begin{array}{l}\text { Percentage of residents within walking distance of defined diverse } \\
\text { uses that provide a measure of mixed-used development. }\end{array}$ & $\mathrm{nr}$ & 1 \\
\hline & D3_DESIGN & \multicolumn{2}{|c|}{ Cincinnati, $\mathrm{OH}$} \\
\hline
\end{tabular}




\begin{tabular}{|c|c|c|c|}
\hline & $\begin{array}{l}\text { D3 TOTAL } \\
\text { MIN-MAX RANGE: } 16-80\end{array}$ & \multicolumn{2}{|l|}{52} \\
\hline & Neighborhood-level connectivity & 9 & \\
\hline 1 & Intersection density, (number of intersections per square unit of area) & acc & 3 \\
\hline 2 & Absence of barriers such as six lane roads. & $\mathrm{nr}$ & 1 \\
\hline \multirow[t]{2}{*}{3} & $\begin{array}{l}\text { A center: Walkable neighborhoods have a center, whether it's a main } \\
\text { street or a public space. }\end{array}$ & yes & 5 \\
\hline & Path-trail connectivity & 3 & \\
\hline 4 & Trail availability per 1,000 residents & $\mathrm{nr}$ & 1 \\
\hline 5 & Bicycle path availability per 100 residents & $\mathrm{nr}$ & 1 \\
\hline \multirow[t]{2}{*}{6} & Path/trail connectivity, internal and with street network & $\mathrm{nr}$ & 1 \\
\hline & Street and sidewalk level pedestrian environment & 15 & \\
\hline 7 & Street trees & yes & 5 \\
\hline 8 & Street widths & yes & 5 \\
\hline 9 & Sidewalk qualities & acc & 3 \\
\hline 10 & Form as a measure of streetscape continuity (empty lots, blank walls) & yes & 1 \\
\hline \multirow[t]{2}{*}{11} & $\begin{array}{l}\text { Other qualities that distinguish walkable environments creating com- } \\
\text { plete streets designed for bicyclists, pedestrians, and transit }\end{array}$ & $\mathrm{nr}$ & 1 \\
\hline & Building level pedestrian adaptations & 25 & \\
\hline 12 & Buildings are close to the street & yes & 5 \\
\hline 13 & Building entrances are oriented to the street & yes & 5 \\
\hline 14 & Parking lots are relegated to the back & yes & 5 \\
\hline 15 & Stores at a reasonable square footage for small towns & yes & 5 \\
\hline \multirow[t]{4}{*}{16} & Building transparency & yes & 5 \\
\hline & D4_DESTINATIONS/ACCESS & \multicolumn{2}{|c|}{ Cincinnati, $\mathrm{OH}$} \\
\hline & $\begin{array}{l}\text { D4 TOTAL } \\
\text { MIN-MAX RANGE: } 21-105\end{array}$ & \multicolumn{2}{|l|}{67} \\
\hline & Places to go & 22 & \\
\hline 1 & $\begin{array}{l}\text { The sum of retail and businesses including recreation and schools } \\
\text { within } 800 \text { meters or } .5 \text { miles }\end{array}$ & $\mathrm{nr}$ & 1 \\
\hline 2 & Presence of places to go that provide services to residents & yes & 5 \\
\hline 3 & Presence of places to go open for business & acc & 3 \\
\hline 4 & Ease of access to destinations within a given distance & acc & 3 \\
\hline 5 & Parks and public spaces & yes & 5 \\
\hline \multirow[t]{3}{*}{6} & $\begin{array}{l}\text { Recreational facilities such as gym/fitness facilities, and other recre- } \\
\text { ational uses }\end{array}$ & yes & 5 \\
\hline & Infrastructure & 45 & \\
\hline & Adequate infrastructure to facilitate walking, such as: & 26 & \\
\hline
\end{tabular}




\begin{tabular}{|c|c|c|c|}
\hline 7 & Sidewalk continuity/coverage & $\mathrm{nr}$ & 1 \\
\hline 8 & Comfortable sidewalks & $\mathrm{nr}$ & 1 \\
\hline 9 & Curbcuts & yes & 5 \\
\hline 10 & Street furniture & $\mathrm{nr}$ & 1 \\
\hline 11 & Bike racks & yes & 5 \\
\hline 12 & Pedestrian friendly intersections & $\mathrm{nr}$ & 1 \\
\hline 13 & Traffic signals & $\mathrm{nr}$ & 1 \\
\hline 14 & Speed limits, & yes & 5 \\
\hline 15 & Traffic calming & $\mathrm{nr}$ & 1 \\
\hline \multirow[t]{2}{*}{16} & Other traffic measures & yes & 5 \\
\hline & Pleasant environment & 19 & \\
\hline 17 & A pleasant environment to walk with attractive features & yes & 5 \\
\hline 18 & Outdoor dining & acc & 3 \\
\hline 19 & Personal Safety such as absence of litter, graffiti, windows with bars & $\mathrm{nr}$ & 1 \\
\hline 20 & Open Views & yes & 5 \\
\hline \multirow[t]{4}{*}{21} & Maintenance. & yes & 5 \\
\hline & D5_DISTANCE & \multicolumn{2}{|c|}{ Cincinnati, $\mathrm{OH}$} \\
\hline & $\begin{array}{l}\text { D5 TOTAL } \\
\text { MIN-MAX RANGE: } 8-40\end{array}$ & \multicolumn{2}{|l|}{32} \\
\hline & 5 or 10 minute walk proximity & & \\
\hline 1 & $\begin{array}{l}1 / 4 \text { to } 1 / 5 \text { mile radius from home to key destinations or up to } 1 / 2 \text { mile } \\
\text { radius segments. }\end{array}$ & yes & 5 \\
\hline 2 & Average distance to the downtown & Wk & 5 \\
\hline 3 & Average distance or time to nearest attractions within a given area & Wk & 5 \\
\hline 4 & Average distance or travel time from home to the nearest store & Wk & 5 \\
\hline 5 & Average distance to jobs within a given area & Wk & 5 \\
\hline 6 & Average distance to nearest jobs & Wk & 5 \\
\hline 7 & Average distance to the nearest transit stop or station & $\mathrm{nr}$ & 1 \\
\hline 8 & Average distance between transit stops & $\mathrm{nr}$ & 1 \\
\hline
\end{tabular}




\subsubsection{Heart of Peoria Form-Based Code (2010 Driehaus Award)}

\section{Project Description}

\section{Heart of Peoria Plan}

The Heart of Peoria Form-Based Code is the implementation instrument of the Heart of Peoria Plan developed in 2002 as a New Urbanist approach to revitalizing downtown Peoria. The Heart of Peoria Plan is a strategic document, a master plan with form-based codes, that sets principles and suggests directions for the successful revitalization of Peoria's downtown for the next 20 years. The plan aims at improving the quality and competitiveness of the downtown by creating a walkable and pedestrian friendly environment borrowing from the principles of New Urbanism and the SmartCode. The document serves as a preliminary form-based code as well providing a regulating plan and specific guidelines on how to proceed on detailed code overhauls for select downtown areas. The regulating plan "is only a first cut at the process, with the aim of repairing the most obvious

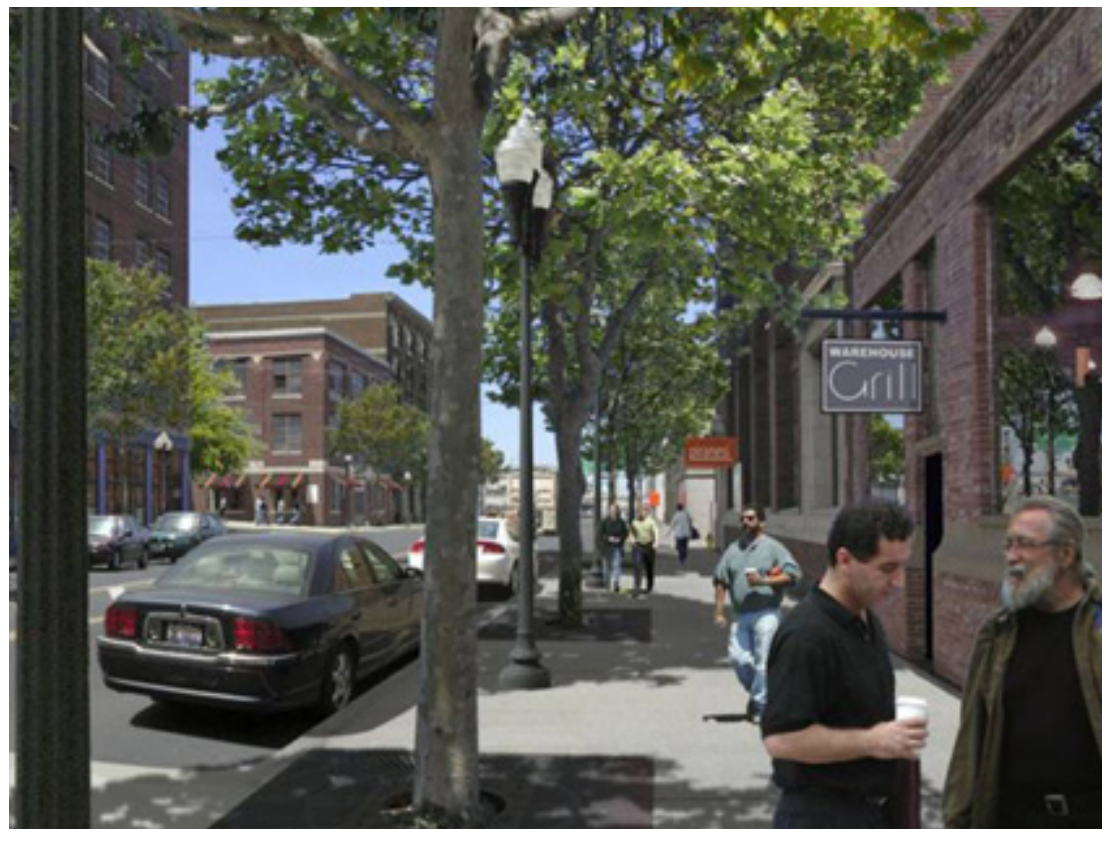

Figure 39: Illustration showing desired pedestrian-oriented streetscape in Peoria, IL. Adapted from Publications. Appendix C - Heart of Peoria Land Development Code. Municode.com. by the City of Peoria, IL, 2014b, p. 1. 
of the problems in the existing land use plan and making mostly subtle changes in accordance with the goals of this plan" (City of Peoria, IL, 2002, p. III.6). The regulating plan simplifies existing zoning into three urban zones (urban core, central urban and urban general), a suburban and two rural zones and proposes changes. The plan also identifies potentially walkable streets and routes, automobile oriented streets, proposes new street configurations, new development in select areas, and identifies neighborhood centers with $5 \mathrm{~min}$ and $10 \mathrm{~min}$ pedestrian sheds around them. Figure 39 shows an illustration of desired pedestrian-oriented streetscape in Peoria, IL, part of the Heart of Peoria Plan.

\section{Land Development Code for the Heart of Peoria}

The Heart of Peoria Plan is a master plan suggests solutions that include a regulating plan (Figure 40), new site plans for pedestrian-oriented neighborhood centers in selected areas (Figure 41) and directions for form-based zoning and regulations. The implementing instrument however is the Land Development Code for the Heart of Peoria adopted in 2007 that includes the necessary standards and regulations to make suggested visions for the downtown reality. The code is a hybrid form-based code retaining use-based zones in non pedestrian oriented pre-existing residential neighborhoods, while delineating form-based districts in select downtown areas (Figure 41) in accordance to the Heart of Peoria Plan.

All zones in the code are called Districts. These are: Base Districts (Residential, Commercial, Industrial, Institutional, and Parking), Form Districts, and Overlay Districts. Residential Districts intend to preserve the pre-existing residential character of the neighborhood and increase residential density where necessary. Industrial Districts are without pedestri- 
an environment enhancing standards. The Commercial Districts on the other hand intend to: "reestablish the historic pattern of mixed use, pedestrian-oriented commercial corridors adjacent to residential neighborhoods within the Heart of Peoria by allowing for a vibrant mix of residential, retail, and commercial uses within close proximity of one another" (City of Peoria, 2014b, p. 4-5). In this case study, the districts reviewed to assess the three quality are the Commercial and the Form Districts.

\section{Neighborhood Principle}

The Heart of Peoria Plan regulating plan identifies potential walkable neighborhoods and suggests walkable solutions in those areas and the interconnecting streets. The Heart of Peoria Land Development Code includes standards and regulations to implement such recommendations. Table 22 presents the Neighborhood principle parameter evaluations for Heart of Peoria Plan. All 3 parameters were initially delineated in the Heart of Peoria Plan but the Heart of Peoria Land Development Code applied the parameters very effectively. Placing the pedestrian shed circles identified in the Heart or Peoria Plan over the City of Peoria Zoning District Map (Figure 42) helps identify how well the zoning code responded to the Heart of Peoria Plan suggestions for walkable neighborhoods. 17 out of the 19 identified pedestrian sheds have a zoned commercial area in their center and two sheds include commercial areas within their periphery or in proximal distance of less than .1 mile from their periphery.

\begin{tabular}{|l|l|l|}
\hline \multicolumn{2}{|l|}{ Table 22: Neighborhood Principle: Heart of Peoria Form-Based Code } & 1 \\
\hline .25 mile or similar radius or a 5 min walk neighborhood & yes & 1 \\
\hline Center with civic and/or mixed uses in regulating plan & partly & 1 \\
\hline Identifiable edge: discussion, mention, or delineations in any plan & Total: & 6 \\
\hline Notes: - &
\end{tabular}




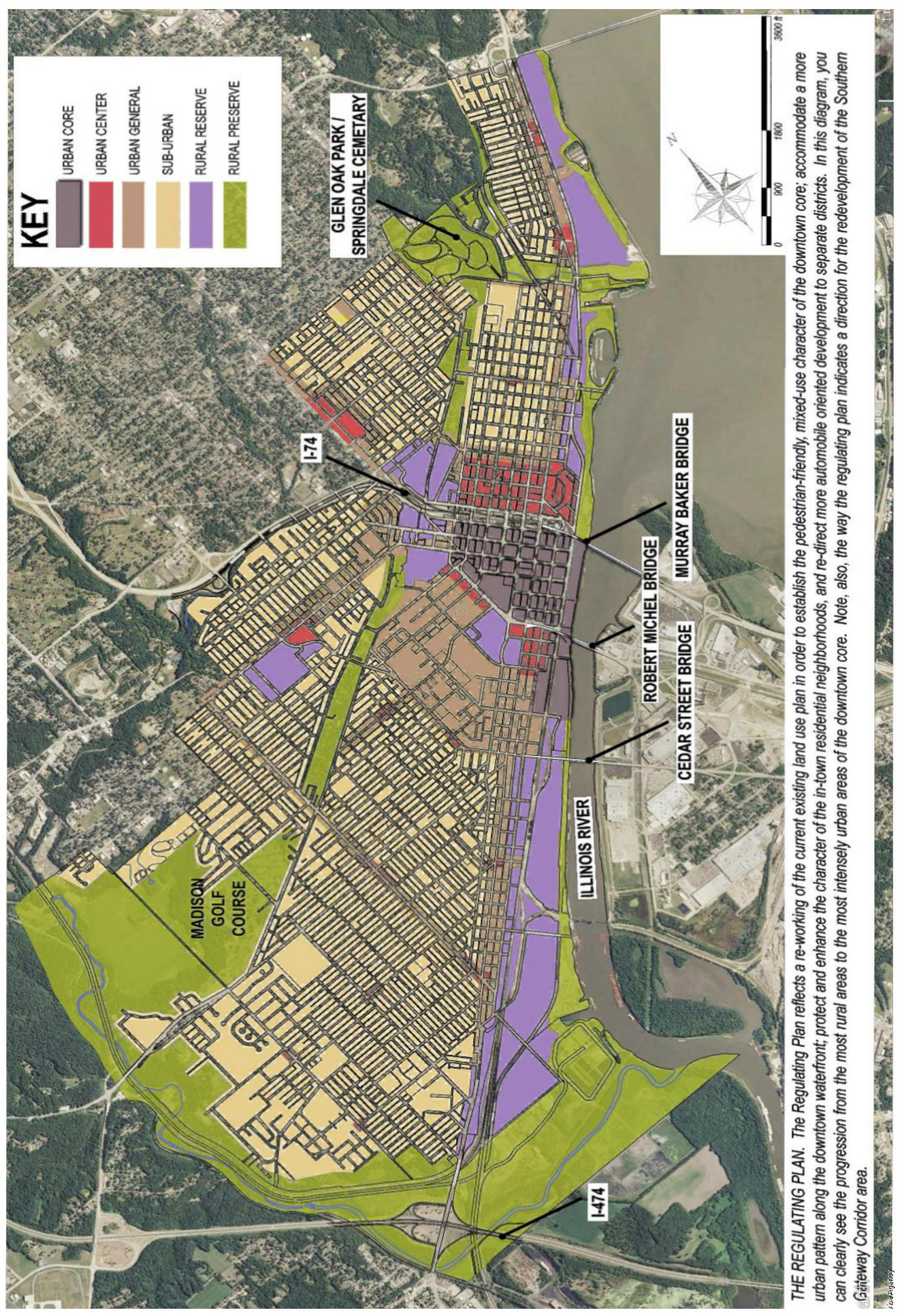

Figure 40: Heart of Peoria Regulating Plan. Adapted from Publications. Heart of Peoria Plan. City of Peoria, Illinois. Peoriagov.org. by the City of Peoria, IL, 2002, p. III.6. 


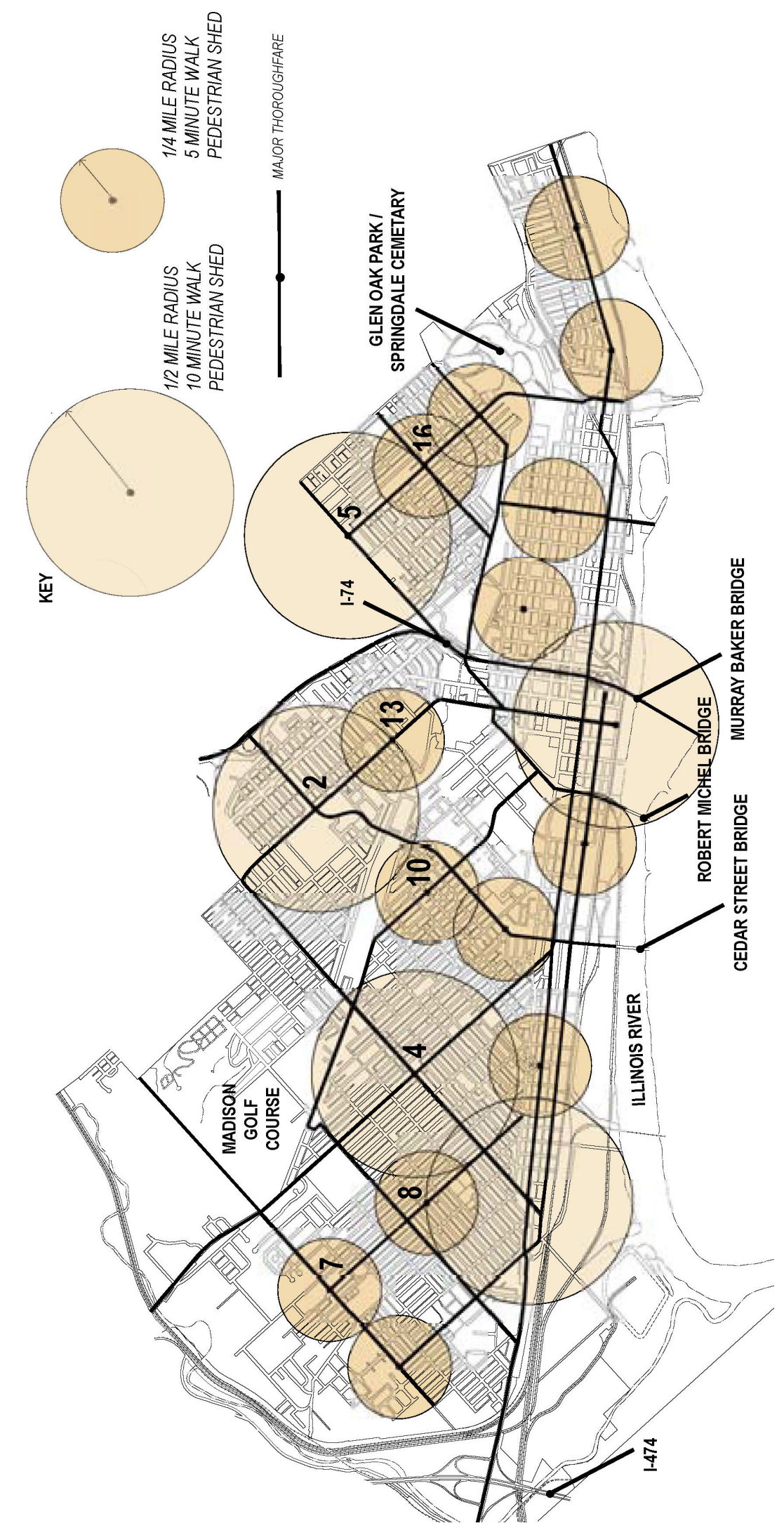

Figure 41: Heart of Peoria Plan identification of neighborhood centers and pedestrian sheds. Adapted from Publications. Heart of Peoria Plan. City of Peoria, Illinois. Peoriagov.org. by the City of Peoria, IL, 2002, p. II.4. 


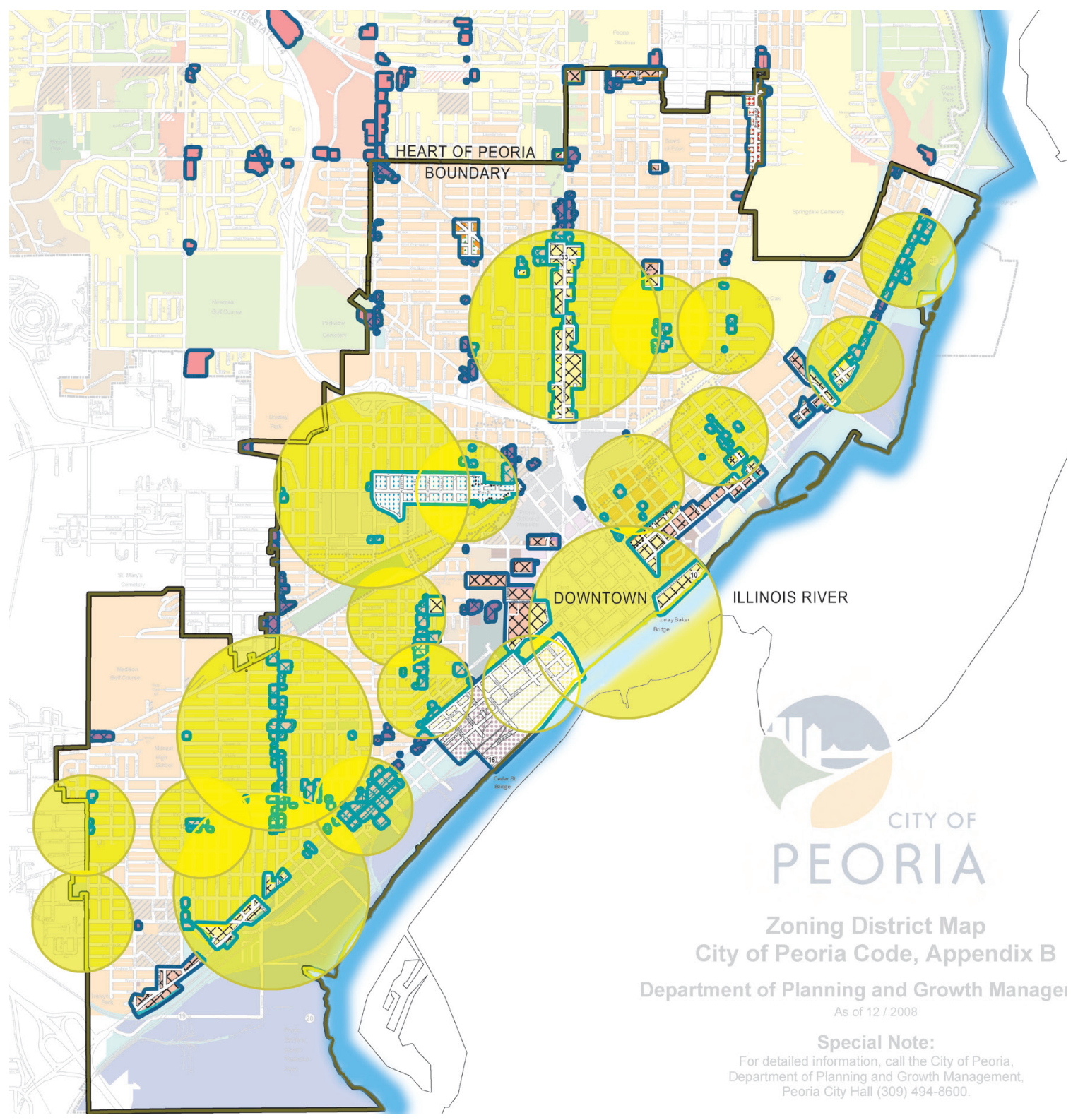

Figure 42: Correspondence of pedestrian sheds (yellow circles) identified in the Heart of Peoria Plan with pedestrian-planned zones (various types of commercial and form-based areas, outlined in blue) in the Zoning District Map. Adapted from Publications. Heart of Peoria Plan. City of Peoria, Illinois. Peoriagov.org. by the City of Peoria, IL, 2002, p. II.4. and City of Peoria Zoning District Map, by the City of Peoria, IL, 2008. 
Proximity to Daily Needs Principle

Looking at Figure 42 it is easy to see that most of the Heart of Peoria area is within a walkable distance of a commercial/office zone placing most of the residents in that area in close proximity to potential jobs, shopping and entertainment. The regulating plan for West Main (Figure 43), one of the selected locations for pedestrian-oriented neighborhood centers and form-based codes, shows a combination of urban intensity areas (as street frontages) and uses to facilitate proximity to a variety of destinations and uses. Table 23 presents the presence of Proximity to Daily Needs principle parameters in the Heart of Peoria Form-Based Code.

\begin{tabular}{|l|l|l|}
\hline Table 23: Proximity to Daily Needs Principle: Heart of Peoria Form-Based Code \\
\hline Residential within .25 mile radius from mixed use/retail/commercial areas & yes & 1 \\
\hline Mixed use, retail, commercial, office development presence in illustrative plan & yes & 1 \\
\hline Mixed use, retail, commercial, office development presence in regulating plan & yes & 1 \\
\hline Mixed use, retail, commercial, office development presence in the zoning code & yes & 1 \\
\hline A diversity of building types in illustrative plan & yes & 1 \\
\hline A diversity of building types in regulating plan & yes & 1 \\
\hline A diversity of building types in the zoning code & yes & 1 \\
\hline Presence of various building types within the .25 mile radius neighborhood & yes & 1 \\
\hline $\begin{array}{l}\text { Notes: } \\
\text { The code is flexible regarding building types and uses allowing flexibility in } \\
\text { height use and building layout. Such flexibilities are laid within requirements } \\
\text { for compatibility with adjacent buildings in height, profile and materials. Build- } \\
\text { ing standards such as height, setbacks and lot location are addressed through } \\
\text { frontage types under district types. }\end{array}$ & & \\
\hline
\end{tabular}

\section{Walkability Principle}

The Heart of Peoria Code has addressed most of the walkability parameters within the 5Ds. The code also addresses many Destination/Accessibility parameters such as bike racks and street furniture. Figure 44 shows pedestrian accommodations in the West Main Street standards. Figure 45 shows built-to lines and building facade continuity along a building's frontage, significant parameters for walkable environments according to WalkS- 
core (2012) and Walkable Communities (2014). Walkability parameters of density, diversity, design, destinations, and distance were evaluated using the criteria shown on Table 5. Table 24 presents the evaluation of Walkability parameters within the $5 \mathrm{Ds}$ for the Heart of Peoria Land Development Code.

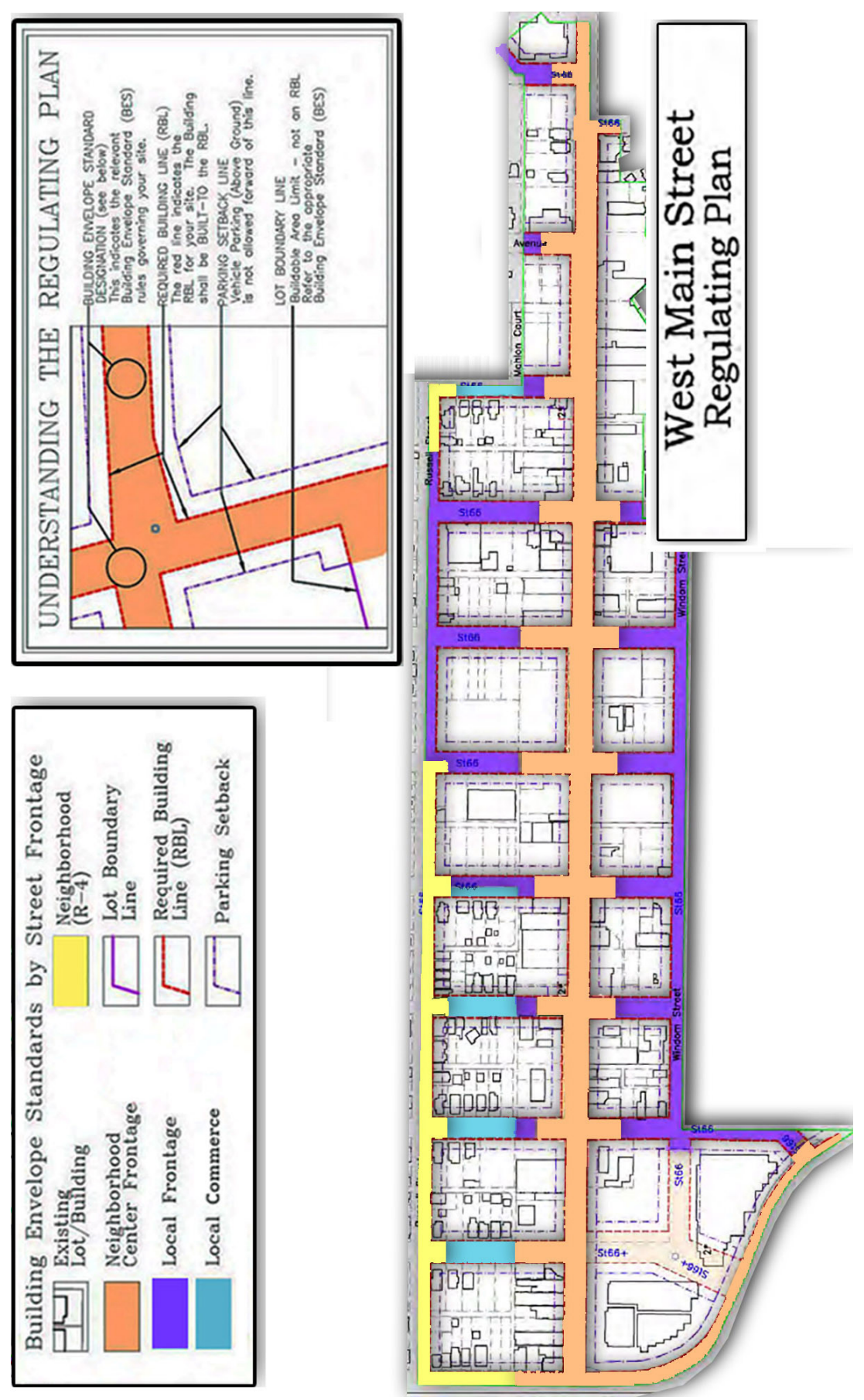

Figure 43: West Main Street Regulating Plan. Adapted from Publications. Appendix C - Heart of Peoria Land Development Code. Municode.com. by the City of Peoria, IL, 2014b, p. 6-15. 


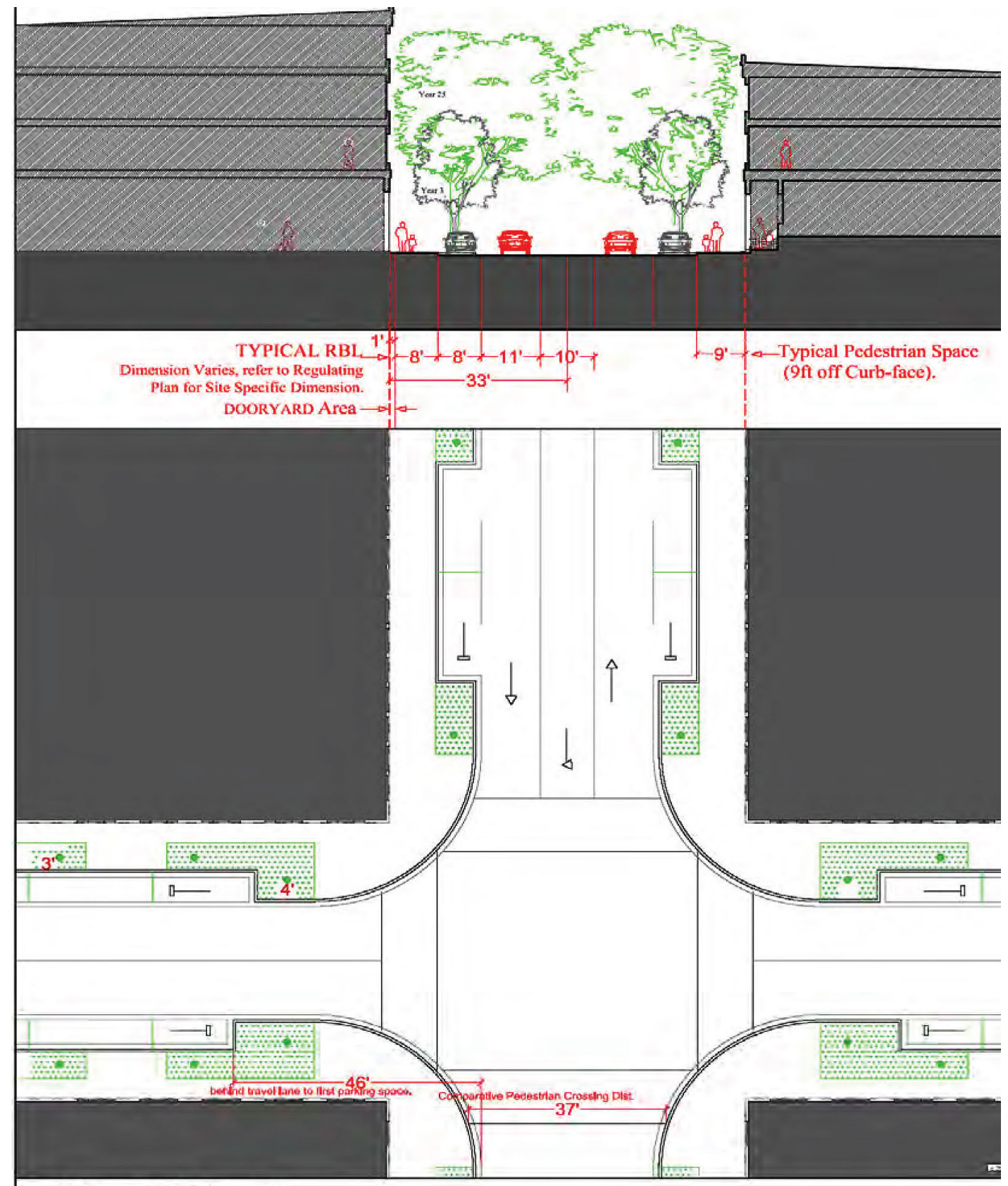

\section{West Main 66}

STREETSPACE: 66 feet. Sidewalks: $8 \mathrm{ft}$. Travel Lanes: 2 @ 11 feet. Center Turn Lane 10 feet. Dedicated Parking/Street Tree Lanes: 8 feet. Tree Planters: 7.5 x 18 feet Minimum.

Figure 44: West Main Street street standards diagram showing pedestrian accommodations. Adapted from Publications. Appendix C - Heart of Peoria Land Development Code. Municode.com. by the City of Peoria, IL, 2014b, p. 6-41. 

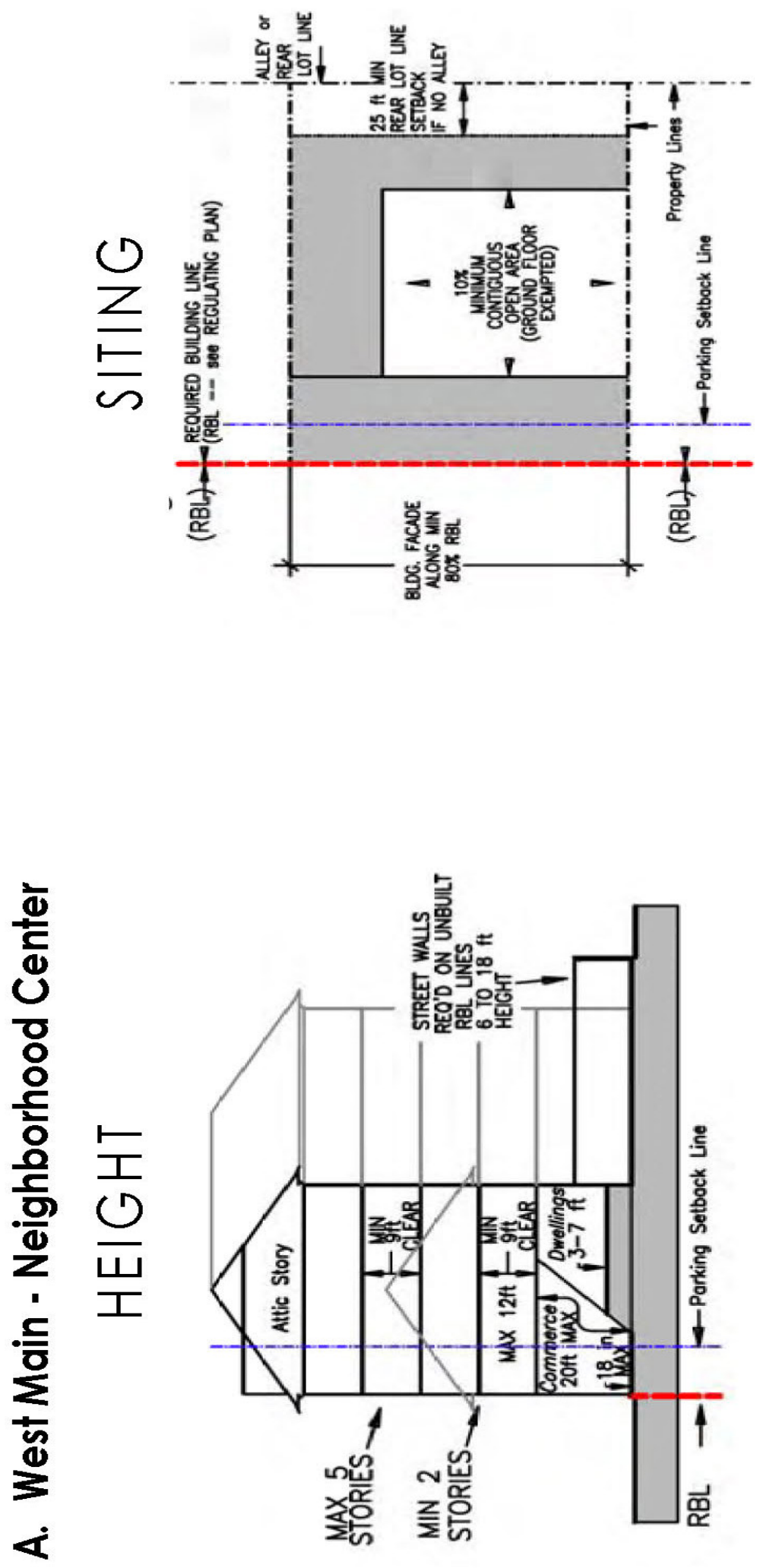

Figure 45: West Main Street Neighborhood Center height and siting standards. Adapted from Publications. Appendix C - Heart of Peoria Land Development Code. Municode.com. by the City of Peoria, IL, 2014b, p. 6-16. 


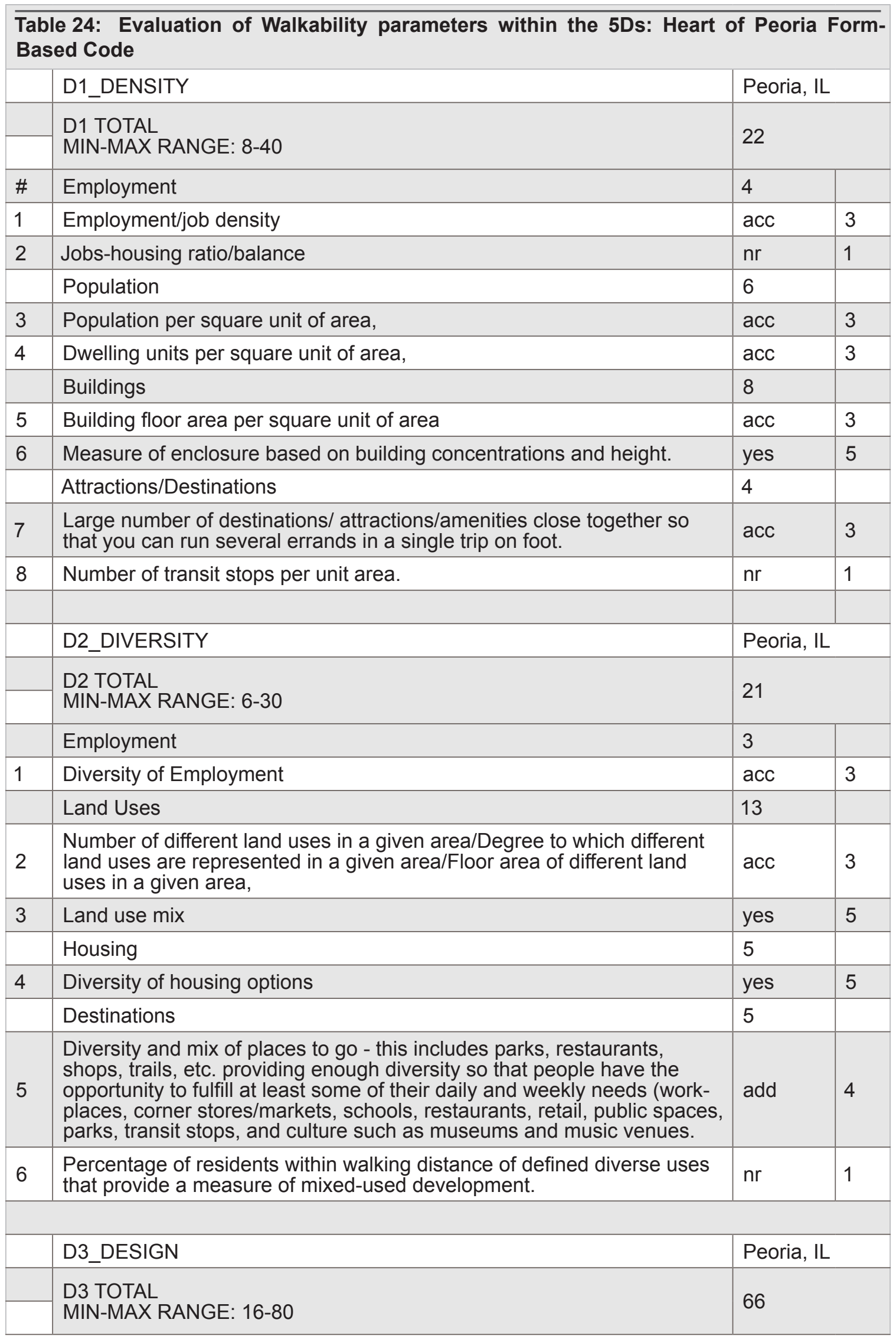




\begin{tabular}{|c|c|c|c|}
\hline & Neighborhood-level connectivity & 13 & \\
\hline 1 & Intersection density, (number of intersections per square unit of area) & add & 4 \\
\hline 2 & Absence of barriers such as six lane roads. & add & 4 \\
\hline \multirow[t]{2}{*}{3} & $\begin{array}{l}\text { A center: Walkable neighborhoods have a center, whether it's a main } \\
\text { street or a public space. }\end{array}$ & yes & 5 \\
\hline & Path-trail connectivity & 3 & \\
\hline 4 & Trail availability per 1,000 residents, & $\mathrm{nr}$ & 1 \\
\hline 5 & Bicycle path availability per 100 residents, & $\mathrm{nr}$ & 1 \\
\hline \multirow[t]{2}{*}{6} & Path/trail connectivity, internal and with street network. & $\mathrm{nr}$ & 1 \\
\hline & Street and sidewalk level pedestrian environment & 25 & \\
\hline 7 & Street trees, & yes & 5 \\
\hline 8 & Street widths, & yes & 5 \\
\hline 9 & Sidewalk qualities & yes & 5 \\
\hline 10 & Form as a measure of streetscape continuity (empty lots, blank walls) & yes & 5 \\
\hline \multirow[t]{2}{*}{11} & $\begin{array}{l}\text { Other qualities that distinguish walkable environments creating complete } \\
\text { streets designed for bicyclists, pedestrians, and transit. }\end{array}$ & yes & 5 \\
\hline & Building level pedestrian adaptations & 25 & \\
\hline 12 & Buildings are close to the street & yes & 5 \\
\hline 13 & Building entrances are oriented to the street & yes & 5 \\
\hline 14 & Parking lots are relegated to the back & yes & 5 \\
\hline 15 & Stores at a reasonable square footage for small towns & yes & 5 \\
\hline \multirow[t]{4}{*}{16} & Building transparency & yes & 5 \\
\hline & D4_DESTINATIONS/ACCESS & \multicolumn{2}{|l|}{ Peoria, IL } \\
\hline & $\begin{array}{l}\text { D4 TOTAL } \\
\text { MIN-MAX RANGE: } 21-105\end{array}$ & \multicolumn{2}{|l|}{70} \\
\hline & Places to go & 18 & \\
\hline 1 & $\begin{array}{l}\text { The sum of retail and businesses including recreation and schools within } \\
800 \text { meters or } .5 \text { miles. }\end{array}$ & acc & 3 \\
\hline 2 & Presence of places to go that provide services to residents. & add & 4 \\
\hline 3 & Presence of places to go open for business & acc & 3 \\
\hline 4 & Ease of access to destinations within a given distance: & & \\
\hline 5 & Parks and public spaces & add & 4 \\
\hline \multirow[t]{3}{*}{6} & $\begin{array}{l}\text { Recreational facilities such as gym/fitness facilities, and other recreation- } \\
\text { al uses }\end{array}$ & add & 4 \\
\hline & Infrastructure & 52 & \\
\hline & Adequate infrastructure to facilitate walking, such as: & 40 & \\
\hline 7 & Sidewalk continuity/coverage & yes & 5 \\
\hline 8 & Comfortable sidewalks & yes & 5 \\
\hline
\end{tabular}




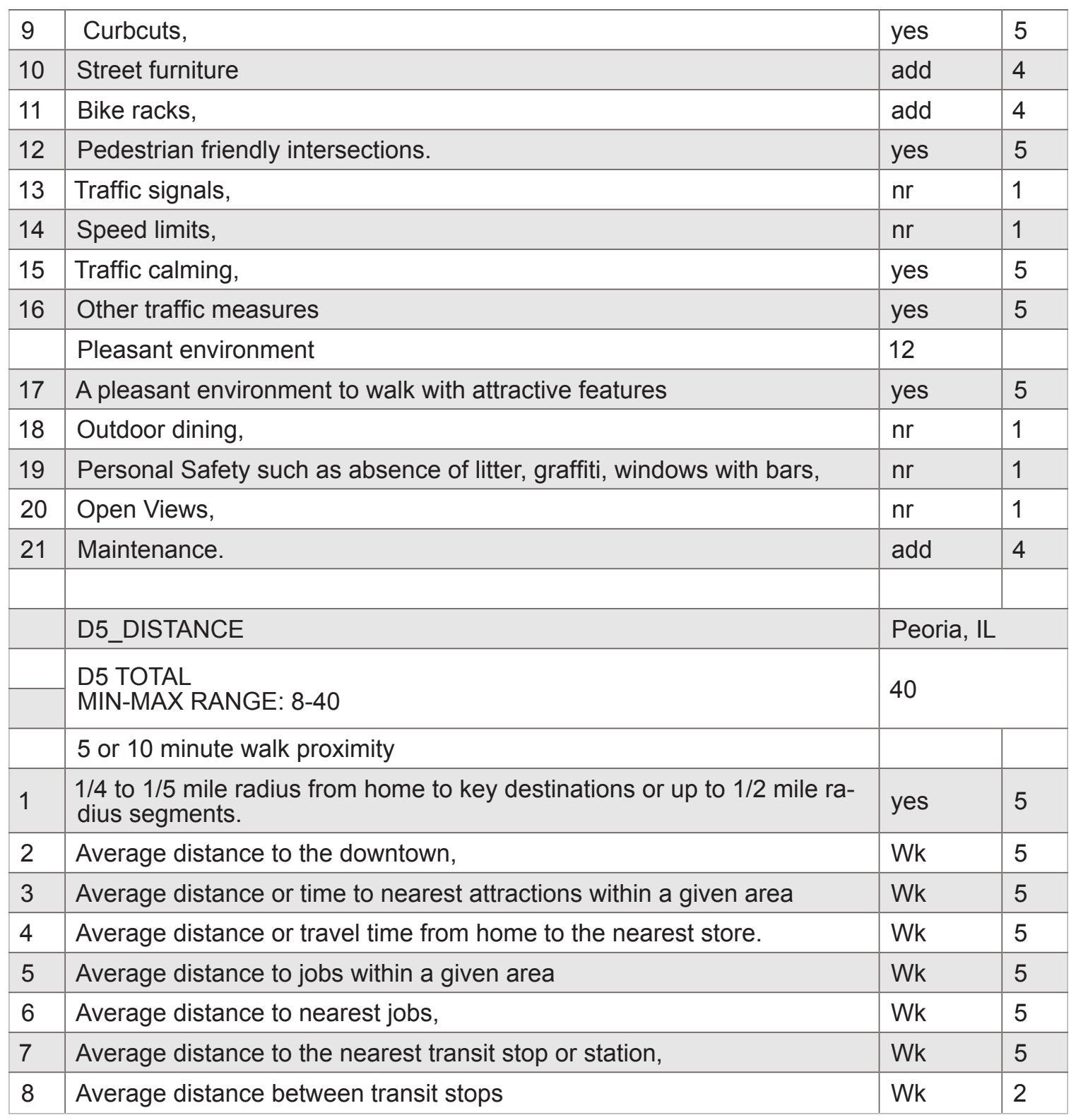




\subsubsection{Case Study Findings}

The 6 case studies explored the presence, type of presence and extent of presence of the three quality of life principles in awarded form-based code efforts from 2007 to 2014 . Neighborhood and Proximity to daily needs were relatively simple to assess due to the small number of parameters under each, 3 and 8 respectively. Walkability, however, is the most complex of the three principles with 58 identified parameters grouped under 16 parameter groups within the sub-principles of Density, Diversity, Design, Destinations, and Distance.

Table 25 compares case studies in the application of the three Quality of Life principles. The rating system used to identify how the case studies addressed the quality of life principles, sorted out studies mostly in response to the numerous walkability parameters. St Lucie County, FL with many provisions for street and sidewalk pedestrian accommodations, received the highest score. Benicia, CA fared lower because street and pedestrian level infrastructure walkability parameters were not addressed adequately.

\begin{tabular}{|l|l|l|l|l|l|l|l|}
\hline \multicolumn{1}{|c|}{ Table 25: Case Study Quality of Life Principles Cumulative Table } \\
\hline & $\begin{array}{c}\text { Range of } \\
\text { possible } \\
\text { score }\end{array}$ & $\begin{array}{c}\text { Sta- } \\
\text { tion } \\
\text { Area }\end{array}$ & $\begin{array}{c}\text { Beni- } \\
\text { cia }\end{array}$ & $\begin{array}{c}\text { St } \\
\text { Lucie }\end{array}$ & $\begin{array}{c}\text { Lee } \\
\text { Coun- } \\
\text { ty }\end{array}$ & $\begin{array}{c}\text { Cin- } \\
\text { cinna- } \\
\text { ti }\end{array}$ & Peoria \\
\hline Neighborhood & $0-3$ & 2 & 2 & 3 & 2.5 & 2 & 3 \\
\hline $\begin{array}{l}\text { Proximity to Daily } \\
\text { Needs }\end{array}$ & $0-16$ & 8 & 8 & 8 & 8 & 8 & 8 \\
\hline Walkability & $59-295$ & 200 & 174 & 225 & 195 & 197 & 216 \\
\hline TOTALS & & 210 & 184 & 236 & 205.5 & 207 & 227 \\
\hline
\end{tabular}

What follows is a comparison and discussion of ratings across the six case studies for each quality of life principle. Acumulative table per principle allows and assists such a comparison. 


\section{Neighborhood}

\begin{tabular}{|c|c|c|c|c|c|c|c|c|c|c|c|c|}
\hline \multirow[b]{2}{*}{$\begin{array}{l}.25 \text { mile or similar radius or } \\
\text { a } 5 \text { min walk neighborhood } \\
\text { in any plan }\end{array}$} & \multicolumn{2}{|c|}{$\begin{array}{l}\text { Farmers } \\
\text { Branch } \\
\text { Station } \\
\text { Area, TX }\end{array}$} & \multicolumn{2}{|c|}{$\begin{array}{l}\text { Benicia, } \\
\text { CA }\end{array}$} & \multicolumn{2}{|c|}{$\begin{array}{l}\text { St } \\
\text { Lucie } \\
\text { County, } \\
\text { FL }\end{array}$} & \multicolumn{2}{|c|}{$\begin{array}{l}\text { Lee County, } \\
\text { FL }\end{array}$} & \multicolumn{2}{|c|}{$\begin{array}{l}\text { Cincin- } \\
\text { nati, OH }\end{array}$} & \multicolumn{2}{|c|}{$\begin{array}{l}\text { Peoria, } \\
\text { ILL }\end{array}$} \\
\hline & yes & 1 & yes & 1 & yes & 1 & partly & 1 & yes & 1 & yes & 1 \\
\hline $\begin{array}{l}\text { Center with civic and/or } \\
\text { mixed uses in any plan }\end{array}$ & yes & 1 & yes & 1 & yes & 1 & yes & 1 & yes & 1 & yes & 1 \\
\hline $\begin{array}{l}\text { Identifiable edge: discus- } \\
\text { sion, mention, or delinea- } \\
\text { tions in any plan }\end{array}$ & no & 0 & no & 0 & yes & 1 & partly & 0.5 & no & 0 & partly & 1 \\
\hline $\begin{array}{r}\text { Total possible score: } 3 \\
\text { Totals: }\end{array}$ & \multicolumn{2}{|c|}{2} & \multicolumn{2}{|c|}{2} & \multicolumn{2}{|c|}{3} & \multicolumn{2}{|c|}{2.5} & \multicolumn{2}{|c|}{2} & \multicolumn{2}{|l|}{3} \\
\hline
\end{tabular}

Note: 'Yes' denotes presence and 'No' absence. 'Partly' in Lee County's case denotes guidelines instead of standards with the use of 'should' instead of 'must' or 'shall.'

The three neighborhood parameters check the presence of the .25 mile radius, the presence of a neighborhood center and the presence of an identifiable edge. All six case studies incorporate the concept of neighborhood as a pedestrian shed, of usually .25 mile radius, with an identifiable center. Since coding zones as transects are identified only after neighborhood delineations, pedestrian sheds with a center appear early in the form-based code process, in the master and illustrative plans. In smaller developments, such as Station Area in Farmer's Branch, TX, there is no need to identify such a radius since the development is already .25 miles in radius. Lee and St Lucie Counties in Florida, require walkable developments for new development plans. Form-based codes overall require predictable results but in Lee County although recommend walkable distances for all developments. the coding standards require .25 mile distances only for new development adjacent to pre-existing centers. Table 26 presents the neighborhood parameter evaluations across the 6 studies. 
The parameter 'neighborhood edges' is absent in three case studies and only partly addressed in Lee County, as part of the 'Edge Transect' required to be same intensity as adjacent development or be next to natural areas. It is not clear, however, whether the Edge Transect can create an identifiable edge for communities. St Lucie County requires open space to form boundaries in new communities. Peoria is an interesting case since the concept of an identifiable edge applies to a multi-neighborhood area. The Heart of Peoria "is ringed with a nearly complete belt of green" (City of Peoria, IL, 2014, p. II-6). Other references to the concept of neighborhood edge appear in the Heart of Peoria Master Plan but none of the proposed Heart of Peoria form-based plans apply an identifiable edge.

In summary:

- All case studies identify the .25 mile radius or the 5 min walkable neighborhood

- All case studies include centers in walkable neighborhoods

- Only one case study, St Lucie County requires an identifiable edge around communities while Lee County and Peoria, IL discuss and address the concept of edge in some notion. 


\begin{tabular}{|c|c|c|c|c|c|c|c|c|c|c|c|c|c|}
\hline \multirow[b]{2}{*}{1} & \multirow[b]{2}{*}{$\begin{array}{l}\text { Residential within } .25 \text { mile } \\
\text { radius of mixed use/retail/com- } \\
\text { mercial areas }\end{array}$} & \multicolumn{2}{|c|}{$\begin{array}{l}\text { Station } \\
\text { Area, TX }\end{array}$} & \multicolumn{2}{|c|}{ Benicia } & \multicolumn{2}{|c|}{$\begin{array}{l}\text { St Lucie } \\
\text { County }\end{array}$} & \multicolumn{2}{|c|}{$\begin{array}{l}\text { Lee } \\
\text { County }\end{array}$} & \multicolumn{2}{|c|}{$\begin{array}{l}\text { Cincin- } \\
\text { nati }\end{array}$} & \multicolumn{2}{|c|}{ Peoria } \\
\hline & & yes & 1 & yes & 1 & yes & 1 & yes & 1 & yes & 1 & yes & 1 \\
\hline 2 & $\begin{array}{l}\text { Mixed use, retail, commercial, } \\
\text { office development presence } \\
\text { in illustrative plan }\end{array}$ & yes & 1 & yes & 1 & yes & 1 & yes & 1 & yes & 1 & yes & 1 \\
\hline 3 & $\begin{array}{l}\text { Mixed use, retail, commercial, } \\
\text { office development presence } \\
\text { in regulating plan }\end{array}$ & yes & 1 & yes & 1 & yes & 1 & yes & 1 & yes & 1 & yes & 1 \\
\hline 4 & $\begin{array}{l}\text { Mixed use, retail, commercial, } \\
\text { office development presence } \\
\text { in the zoning code }\end{array}$ & yes & 1 & yes & 1 & yes & 1 & yes & 1 & yes & 1 & yes & 1 \\
\hline 5 & $\begin{array}{l}\text { A diversity of building types in } \\
\text { illustrative plan }\end{array}$ & yes & 1 & yes & 1 & yes & 1 & yes & 1 & yes & 1 & yes & 1 \\
\hline 6 & $\begin{array}{l}\text { A diversity of building types in } \\
\text { regulating plan }\end{array}$ & yes & 1 & yes & 1 & yes & 1 & yes & 1 & yes & 1 & yes & 1 \\
\hline 7 & $\begin{array}{l}\text { A diversity of building types in } \\
\text { the zoning code }\end{array}$ & yes & 1 & yes & 1 & yes & 1 & yes & 1 & yes & 1 & yes & 1 \\
\hline \multirow[t]{2}{*}{8} & $\begin{array}{l}\text { Presence of building types } \\
\text { within the } .25 \text { mile radius } \\
\text { neighborhood }\end{array}$ & yes & 1 & yes & 1 & yes & 1 & yes & 1 & yes & 1 & yes & 1 \\
\hline & $\begin{array}{r}\text { Total possible score: } 8 \\
\text { Totals: }\end{array}$ & \multicolumn{2}{|c|}{8} & \multicolumn{2}{|c|}{8} & \multicolumn{2}{|c|}{8} & \multicolumn{2}{|l|}{8} & \multicolumn{2}{|c|}{8} & \multicolumn{2}{|c|}{8} \\
\hline
\end{tabular}

The principle of Proximity to Daily Needs appears early in the form-based code process in master and illustrative plans since after the delineation of neighborhoods, centers with retail, commercial and office space are defined. All 8 Proximity to Daily Needs parameters are highly incorporated in the six case studies. Residential, mixed-use, office, retail, and commercial developments are specified in all steps of the form-based code process in all studies along with a variety of building types. The illustrative plans show depictions of multi-use pedestrian areas, the regulating plans identify the higher density coding zones for centers within neighborhoods, and the zoning standards ensure the implementation 
of such a plan by providing the relevant zoning standards and allow for the relevant uses. Table 27 presents the 8 parameter evaluations across the 6 studies.

Residential housing is present within the pedestrian sheds often as mixed-use, and beyond the neighborhood boundaries as residential zones. In the .25 mile radius Farmers Branch case study in Dallas, commercial and retail uses exist throughout the development with residential uses within .25 miles off the development taking advantage of the proximity. In such case, a .25 mile downtown development increases the walkability of surrounding neighborhoods.

Simply providing for mixed-use buildings, variety of building types and a variety of housing types within a walkable distance of .25 miles, however, does not make form-based codes any different than use-based codes. There are plenty of retail centers in suburban areas across the country. The addition of mixed-use buildings simply adds flexibility in use and across the country many use-based codes allow for mixed-use zones. The important difference between use-based and form-based codes is the intentional considering of and incorporation of residencies within walkable proximity of such uses as an attempt to decrease automobile use and provide alternative means of transportation, and most importantly, walking. In addition, form-based codes, with the avoidance of use-based zones, often require a higher a mix of building types and lot sizes that facilitate flexibility in use, mixing of uses and more opportunities for proximity between residential spaces and commercial, retail, or office that respond to daily needs.

In summary: 
- All case studies include residential within a .25 mile radius area

- All case studies provide for mixed use, retail, commercial, office development presence in the illustrative plan, regulating plan and the zoning code.

- All case studies include a diversity of building types in the illustrative plan, regulating plan and the zoning code.

- All case studies include a variety of building types within the .25 mile radius neighborhood. 
Walkability

\begin{tabular}{|c|c|c|c|c|c|c|c|}
\hline $5 \mathrm{Ds}$ & $\begin{array}{l}\text { Range of possi- } \\
\text { ble score }\end{array}$ & $\begin{array}{l}\text { Station } \\
\text { Area }\end{array}$ & $\begin{array}{l}\text { Beni- } \\
\text { cia }\end{array}$ & $\begin{array}{l}\text { St } \\
\text { Lucie }\end{array}$ & $\begin{array}{l}\text { Lee } \\
\text { County }\end{array}$ & $\begin{array}{l}\text { Cin- } \\
\text { cinnati }\end{array}$ & $\begin{array}{l}\text { Peo- } \\
\text { ria }\end{array}$ \\
\hline D1_DENSITY & RANGE: 8-40 & 18 & 22 & 21 & 21 & 21 & 22 \\
\hline Employment & Range: 2-10 & 4 & 4 & 4 & 4 & 4 & 4 \\
\hline Population & Range: 2-10 & 6 & 6 & 6 & 6 & 6 & 6 \\
\hline Buildings & Range: 2-10 & 4 & 7 & 6 & 6 & 6 & 8 \\
\hline Attractions/Destinations & Range: 2-10 & 4 & 5 & 5 & 5 & 5 & 4 \\
\hline D2_DIVERSITY & RANGE: $6-30$ & 16 & 20 & 23 & 17 & 21 & 21 \\
\hline Employment & Range: $1-5$ & 3 & 3 & 3 & 3 & 4 & 3 \\
\hline Land Uses & Range: 2-10 & 9 & 8 & 9 & 8 & 8 & 8 \\
\hline Housing & Range: $1-5$ & 1 & 3 & 5 & 4 & 4 & 5 \\
\hline Destinations & Range: 2-10 & 6 & 6 & 6 & 2 & 5 & 5 \\
\hline D3_DESIGN & RANGE: $\mathbf{1 6 - 8 0}$ & 69 & 55 & 61 & 63 & 52 & 66 \\
\hline $\begin{array}{l}\text { Neighborhood-level } \\
\text { connectivity }\end{array}$ & Range: 3-15 & 15 & 15 & 15 & 14 & 9 & 13 \\
\hline Path-trail connectivity & Range: 3-15 & 7 & 4 & 6 & 3 & 3 & 3 \\
\hline $\begin{array}{l}\text { Street and sidewalk } \\
\text { level pedestrian envi- } \\
\text { ronment }\end{array}$ & Range: 5-25 & 22 & 15 & 15 & 21 & 15 & 25 \\
\hline $\begin{array}{l}\text { Building level pedestrian } \\
\text { adaptations }\end{array}$ & Range: 5-25 & 25 & 21 & 25 & 25 & 25 & 25 \\
\hline $\begin{array}{l}\text { D4_DESTINATIONS/ } \\
\text { ACCESS }\end{array}$ & RANGE: 21-105 & 63 & 40 & 80 & 63 & 67 & 70 \\
\hline Places to go & Range: 6-30 & 21 & 21 & 16 & 19 & 22 & 18 \\
\hline $\begin{array}{l}\text { Infrastructure } \\
\text { Adequate infrastructure } \\
\text { to facilitate walking, } \\
\text { such as: }\end{array}$ & Range: $10-50$ & 33 & 10 & 48 & 30 & 26 & 40 \\
\hline Pleasant environment & Range: 5-25 & 9 & 9 & 16 & 14 & 19 & 12 \\
\hline D5_DISTANCE & RANGE: 8-40 & 34 & 37 & 40 & 31 & 36 & 37 \\
\hline $\begin{array}{l}5 \text { or } 10 \text { minute walk } \\
\text { proximity }\end{array}$ & Range: 8-40 & 34 & 37 & 40 & 31 & 36 & 37 \\
\hline \multicolumn{2}{|c|}{$\begin{array}{r}\text { Walkability case total range: } 59-295 \\
\text { Totals: }\end{array}$} & 200 & 174 & 225 & 195 & 197 & 216 \\
\hline
\end{tabular}

The principle of Walkability appears early in the form-based code process in master and illustrative plans as depictions of walkable areas, assignment of pedestrian sheds, walkable neighborhoods, and assignment of street types. However, Walkability is highly 
present in the zoning standards phase with multiple standards and regulations affecting building placement, building architecture and disposition to the street, and streetscape environment, both sidewalk and streets. .

Walkability is explored in the case studies with 58 identified parameters grouped under 16 parameter groups within the sub-principles of the 5Ds: Density, Diversity, Design, Destinations, and Distance. Table 28 shows the effectiveness with which each case study addressed the 5Ds of walkability. The table shows rating range and ratings for Ds and parameter groupings. For individual parameters under parameter groupings see Table 2.

Walkability parameters were assessed by the presence of "shall" regulations and standards within the form-based code. A shall regulation reflecting the walkability parameter was assigned a rating of 5 . If the code or the master plan included a "should," a guideline or recommendation instead of a "shall" then the walkability parameter was assigned a rating of 2 . See Table 5 for the range of evaluations of walkability parameters. All standards and regulations (that included a "shall") from each zoning code were extracted and listed on an excel spread sheet for easier correlation with walkability parameters. St Lucie County, FI and Peoria, IL fare the best with 225 and 216 respectively out of a total of 295 possible. Station Area, TX, Lee County, FL, and Cincinnati, OH are next with 200, 195, and 197 out of 295 respectively. The lowest score in walkability is by Benicia, CA, 174 out of 295 due to low incorporation of street and sidewalk parameters. What follows is a short description of the walkability results for each of the 5Ds across case studies. 


\section{D1: Density}

Density requirements for walkability are addressed through the parameter groupings of employment, population, buildings and attractions/destinations. In all case studies Density was rated between 18 to 22 out of 40 . The ratings are relatively low and it shows that density parameters are not tightly controlled by form-based code standards. The code standards in the form-based code however, set the stage for the 8 density parameters under population, housing, employment and destination to take place.

Employment density was rated the lowest since a form based code can only provide the necessary uses and necessary diversity of buildings but cannot guarantee the presence of employers, business success or vacancies. In addition, providing the necessary number of business uses or assessing a needed jobs-housing ratio would require marketing and demographic studies, not present in most of the material available and if present as in the Cincinnati and St Lucie codes, was not evaluated for its effectiveness. Demographics or market determination studies are necessary for the form-based code to more specifically address many of the parameters under Density.

Similarly, population density measures were not present in the codes studied, therefore it was not clear whether the form-based code responded to the local demands for housing units, population per square unit of area, or the necessary jobs-housing ratio/balance.

Even a form-based code that responded to market and demographics studies would probably not be able guarantee the presence of employers, business success or vacancies. As a result, most of the parameters were evaluated as 'addressed' or 'accommodated' 
based on the presence of allowed uses and the variety of buildings. The Cincinnati code accompanied by the Cincinnati Plan is probably the best available example of the 6 case studies that shows the depth of such market and demographics analyses (City of Cincinnati, 2013 and 2014).

All case studies included standards for building lot coverage and frontage coverage that accommodate high building density in the center of neighborhoods and provide for a continuous line. As a result the measure of enclosure parameter although not addressed directly is expected to be satisfied with standards increasing building lot coverage and frontage. Of the 6 case studies, only the Peoria code specifically required buildings to be aligned and close to the street in Form-District Standards.

\section{D2: Diversity}

Diversity requirements for walkability are addressed through employment, land use, and destinations. Similarly to Density, some of these parameters require market and demographic analyses and studies and are not directly addressed in the form-based code standards or the vision plan. However, Diversity parameters are accommodated by the requirement for various building types, required variety of lot types, and uses.

The parameter number of land uses in a given area is generally accommodated by the requirement for various building types, permitted lot types, permitted uses and permitted street types in every transect. The Cincinnati code specifically requires a variety of lot sizes within a block and says that "blocks shall provide a diversity of residential and 
mixed-use building types in a manner that fulfills the intent of each transect zone" (City of Cincinnati, 2014, p. 6-13). From the results, it seems that the Benicia, CA and Cincinnati, $\mathrm{OH}$ form-based codes, designed by Opticos Design, Inc., and the St. Lucie County and Peoria codes designed by Duany Plater-Zyberk \& Company, LLC., addressed the issue of land use mix more effectively.

\section{D3: Design}

Design requirements for walkability are addressed through neighborhood-level connectivity, path-trail connectivity, street and sidewalk level pedestrian environment, and building level pedestrian adaptations. All studies addressed very well building level pedestrian adaptations and street and sidewalk level pedestrian environment.

Neighborhood-level connectivity is often pre-existing as in Benicia, CA with the pre-existing highly interconnected grid-system. The same can be true for path-trail connectivity. However, no case study responded effectively to path-trail connectivity. The strong focus on the street and the building may create either a neglect of lack of ability of form-based codes to address path and trail connectivity. Addressing such a parameter would possible require form-based codes to incorporate a path and trail master plan within the code. Many case studies addressed the issue to some extent but none offered anything more than recommendations. This could represent a limitation in form-based codes, possibly derived from the architectural origins of the codes or may simply be beyond a form-based code's scope. One of the characteristics of form-based codes however is a comprehensive approach to planning incorporating several documents under one document thus simplifying the zoning process (Polyzoides, 2008, p. xviii). 
Response to street and sidewalk level pedestrian environment is not consistent through the codes studied with the Lee County and Benicia Codes not regulating many of the parameters. This parameter grouping includes street trees, street widths, sidewalk qualities, form as a measure of streetscape continuity (empty lots, blank walls), other qualities that distinguish walkable environments, creating complete streets designed for bicyclists, pedestrians, and transit. Many of these parameters were not addressed in the case studies. Streets were well-addressed in the Cincinnati and Peoria codes but not addressed in the Benicia code.

Building Level Pedestrian Adaptations were consistently addressed with the use of coding standards in all 6 case studies. The parameters under this grouping are, buildings close to the street, building entrances oriented to the street, parking lots are relegated to the back, stores at a reasonable square footage for small town, and building transparency. Formbased codes seem specifically tailored to address these walkability parameters.

\section{D4: Destination/Access}

Destination/Access requirements for walkability are addressed through parameter groupings of places to go, infrastructure, and pleasant environment. With the exception of the pleasant environment all case studies responded well to Destination parameters.

Places to go, is either addressed or accommodated indirectly by the provision of mixeduse and variety of lot and buildings requirements. Some studies specifically recommend public use buildings and open spaces thus addressing destination more specifically. 
Infrastructure with streetscape requirements was not effectively addressed in the case studies. The Benicia code did not address infrastructure. The St Lucie County and Peoria codes, both by Duany Plater-Zyberk \& Company, LLC (Peoria's code was designed by Ferrell Madden Associates LLC while the master plan by Duany Plater-Zyberk \& Company, LLC) were the most inclusive in infrastructure requirements. Benicia, CA did not address these parameters effectively and scored lower. A question arises of whether a form-based code can actually address and to what extent street infrastructure requirements especially in presence of strong Departments of Transportation such as Caltrans in California. Parameters for a pleasant environment are often accommodated through infrastructure and destination parameters. Only the Cincinnati code addressed Views and only the Cincinnati and Lee County codes addressed maintenance in their standards. Views and maintenance parameters were addressed by Cincinnati and Lee Counties only.

Pleasant environment is addressed with the parameters of attractive features, outdoor dining, open views, personal safety such as absence of litter, graffiti, windows with bars, and maintenance. Standards addressing these parameters are lacking overall with the Lee County Code not regulating most of the parameters. This is where the form-based code enters the realm of design and may simply be beyond the scope of a code to address attractive features and a pleasant environment. Graffiti, windows with bars and maintenance could be addressed in the code standards.

\section{D5: Distance}

Distance parameters are addressed very effectively since all case studies delineated .25 mile walkable neighborhoods. Along with the presence of residential uses within the .25 
mile radius the codes included parameters for average distance to downtown, attractions, stores, possible jobs, and possible transit. The codes' response to transit varied from route suggestions, stops and distance between stops to more specifically requiring transit stops. Distance between transit stops was considered addressed when specific standards were present. St Lucie County for example very simply required at least one transit node per neighborhood for future service to points outside the neighborhood. Lee County also required accommodation of existing or anticipated public transit in new communities. 


\subsection{Conclusions And Recommendations}

Two types of form-based code intentions were identified:

- Community and urban form intentions and

- Zoning code document and development process intentions.

Quality of Life falls under the community and urban form intentions. The form-based code literature identifies Quality of Life with the principles of Neighborhood, Proximity to Daily Needs, and Walkability. Each principle includes several parameters that help identify the presence of the principle in form-based codes. The 6 case studies investigated, addressed the Quality of Life parameters under every principle effectively and demonstrated a correspondence of the theoretical background of form-based codes with form-based code practice. The rating system identified how the case studies addressed the quality of life principles and sorted out studies according to the ratings.

The most important parameters across principles seem to be the quarter-mile pedestrian shed and the proximity to retail, commercial and office centers near residential uses. Both tools are integral to all three quality of life principles ever reminding of the pedestrian-environment and neighborhood character objectives in form-based codes following the example of old admired traditional American towns.. The quarter-mile pedestrian shed and the proximity to retail, along with the other parameters identified in this document can provide a checklist for quality of life contributions, as defined in the form-based code literature, when planning a form-based code or when assessing an existing one. 
The principle of Neighborhood as a pedestrian shed with a center is included in all case studies. Proximity to Daily Needs is also present in all case studies because of the presence of pedestrian sheds, mixed use, and variety of building types within residential proximity, all integral to form-based codes. Walkability is the most complex Quality of Life principle applied, among others, through pedestrian-shed planning, flexible use standards, standards for buildings, building location, lots, and streets. Building placement and interaction with the sidewalk at the first floor level seems to be where form-based code standards have the most impact in addressing walkable environments. Aspects of walkability seem to require demographic and market studies to explore and address while other aspects such as street and sidewalk design might require additional expertise or collaboration with local transportation agencies or other departments.

A form-based code as a coding document represents the implementation tool of a master plan or other type of vision plan, and is always part of a larger form-based planning process. The six form-based code case studies were explored in all stages of the form-based process. The Cincinnati Form Based Code, is a good example representing this larger process of planning that starts with visioning charrettes, collection of demographic and marketing information, analysis of local conditions and ends with the drafting of the coding document. It represents the implementation tool of the vision document created both by the local population with planners and designers.

At its more complex, a form-based code is not just a zoning document but the result of a process identifying specific needs of a city, planning accordingly based on population, 
jobs, housing, and market dynamics, and culminating with the form-based zoning code. At its simplest form however, a form-based code can provide .25 mile pedestrian sheds, a neighborhood center, building, lot, street, and use standards along with flexibility in uses, that can facilitate walkable environments and address quality of life concerns.

\subsubsection{Neighborhood}

The findings reaffirm the importance of neighborhoods as pedestrian sheds in form-based codes along with the importance of centers with retail, commercial, and office. Although "neighborhood" is the term often used, the "quarter mile pedestrian shed" would be a more accurate way to reference the work identified in the six case studies.

Coding zones as urban intensity zones, or else transects, appear only after the delineation of pedestrian sheds with centers. In approximately small-sized projects such as Farmers Branch or Benicia may not be a need to delineate such sheds. The county- and city-wide case studies, however, identified pedestrian sheds in the beginning of the process. In other studies, not included here, such as the Azusa, CA form-based code, the city is first subdivided into larger planning areas, subsequently every planning area is subdivided into neighborhoods with centers, and eventually every neighborhood is divided into urban intensity coding zones.

A transect is a coding zone and, based on this investigation on the importance of neighborhoods in form-based planning and the dependence of transects on the delineation of neighborhoods, it seems that neighborhoods do not loom as important in form-based 
code literature as transects Transects, however, are dependent on a prior delineation of neighborhoods with centers.

A center with retail, commercial, office, and public uses, will often be created in the periphery of a neighborhood or where many neighborhoods meet. Exploratory and creative work might be necessary to identify potential relations of pedestrian sheds to a center. Although usually appropriately termed, centers may actually be linear in form and laid along corridors with the .25 mile pedestrian shed being simply a .25 mile bubble around the corridor.

Observing the selection of pedestrian sheds in the Cincinnati form-based code (see Figure 35), the speckled nature of the map becomes obvious along with the condensation of pedestrian sheds as forming a larger pedestrian area in the downtown area. A similar phenomenon is observed in Peoria, IL (see Figures 41 \& 42). One can imagine the historic evolution of many cities, from one central downtown .25 mile radius pedestrian shed to an eventual expansion and unification of many pedestrian sheds into the urban expanse observed in many cities such as New York and San Fransisco along with the presence of satellite pedestrian sheds.

It is also important to note that neighborhoods with centers is an idea that proliferated under modernism and use-based codes as well. There are plenty of commercial centers scattered throughout the country in suburban areas. In form-based codes, however, centers are within walkable proximity of residential spaces allowing residents to have transportation choices and especially the option to walking. 
Finally, the concept of the identifiable edge seems underutilized if not existent in many of the reviewed codes. The importance of such a concept, the forms it takes, and its necessity in assisting quality of life in communities needs further investigation. Quite possibly an identifiable neighborhood edge is significant for reasons of community identity. The concept may loom more important when exploring other intentions of form-based codes such as place-specificity (see Chapter 3 for a breakdown of form-based code intentions). Perry (1929) emphasized the importance of a clear and identifiable edge in neighborhoods as aiding in creating a distinct entity in public consciousness.

\subsubsection{Proximity to daily needs}

With delineation of pedestrian sheds, requirements for mixed-use, variety of building types and assigning of commercial, retail, and office uses in central areas of neighborhoods, form-based codes seem to address Proximity to Daily Needs parameters very effectively. A form-based code however, could provide walkability to residents beyond the .25 mile area. The case of Station Area at Farmers Branch, TX is important and shows reasonable proximity increase to daily needs in areas outside the .25 mile area form-based code as well. In this case, since commercial, retail, and office uses extend along streets to the edge of the .25 mile radius, proximity to daily needs becomes available to neighboring residents as well.

Proximity to daily needs has the potential of reducing automobile traffic by providing alternative transportation options to residents in addition to reducing time spent commuting. 
The positive environmental potential of reduced vehicular usage can also be significant. Availability of jobs and proximity to otherwise unreachable occupational and nutritional opportunities for underprivileged segments of the population may be an additional benefit. The 20 minute neighborhood plan in Portland (see Figure 18) is such an effort aiming at having $90 \%$ of Portland residents "easily walk or bicycle to meet all basic daily, non-work needs" by 2030 (City of Portland, 2014).

\subsubsection{Walkability}

Density, Diversity, Design, Destination/Accessibility and Distance are the 5 sub-principles of walkability addressed at all levels of form-based planning, from the master and illustrative plans to the zoning standards with 58 identified parameters within several parameter groupings. Form-based codes can provide a more comprehensive approach to walkability by carefully addressing parameters under the 5Ds, including street and sidewalk regulations. The case studies examined addressed land use diversity, building-level pedestrian adaptations, and proximity more effectively than other walkability parameter groupings.

Density Diversity and Distance seem better addressed at the beginning of the form-based process with delineation of pedestrian sheds for Distance and possible identification of population and market dynamics to assist Density and Diversity. Design and Destinations include parameters, that are more heavily dependent on zoning standards. Destination requirements for walkability are addressed or accommodated indirectly by the provision of mixed-use buildings, flexibility of uses, and a variety of lot and building requirements. 
Standards addressing pedestrian infrastructure parameters varied among case studies but Cincinnati, St Lucie, FL and Peoria, IL responded with detailed street standards. A question arises as to what extent a form-based code can actually address street infrastructure requirements especially in the presence of strong Departments of Transportation such as Caltrans in California.

Bicycle and Transit transportation modes are not addressed as effectively in the codes. Bicycle transportation is most-often addressed with the requirement for bicycle racks and bicycle lanes. More research might be needed in investigating other ways a form-based code could address bicycle transportation. Since transit is much larger in scale and requires transportation studies, many case studies reviewed provided only recommendations for transit stop routes, locations, and pattern and two case studies required transit stops in new communities. Form-based codes exhibit an obvious concern and address walkable environments but possible ways to address bicycle and transit may be important if expansion of scope is desired.

Form-based codes are unique and they contribute by introducing a place-based structure of zoning areas. The city is no longer subdivided in use areas but, instead, chunks of the city, neighborhoods or pedestrian sheds, are considered as integrated wholes. Within these integrated wholes, zones of urban density are outlined so residents have the possibility of improving their daily lives through proximity to daily destinations, minimizing commuting and pollution, gaining personal time, spending less on gas, and having a richer set of daily experiences through a multiplicity of encounters with retail, commercial, enter- 
tainment, and personal networking opportunities in pedestrian -and potentially bicycle and transit- accommodating environments.

$\infty \propto \infty \propto \infty$ 


\section{REFERENCES}

Alexander, C., Ishikawa, S. and Silverstein, M. (1977). A Pattern Language. New York: Oxford University Press.

Alfonzo, M. (2012). The State of Place TM Index - Urban Imprint. Urbanimprint.com. Retrieved 14 October 2014, from http://www.urbanimprint.com/state-of-place-index/

Beaufort County, SC. (2013). Daufuskie Island Code. Beaufort County, SC. Retrieved 4 June 2013, from http://www.bcgov.net/departments/Planning-and-Development/planning/Daufuskie-Island-Code.php

Benfield, K. (2013). For walkable cities, it's not about the density - it's about finding the right kind of density. Switchboard. Retrieved from http://switchboard.nrdc.org/blogs/kbenfield/city_density_isnt_the_issue_-.html

Benfield, K. (2013b). Excerpt: The Ecology of People Habitat. Peoplehabitat.com. Retrieved 11 October 2014, from http://www.peoplehabitat.com/excerpt-the-ecology-of-people-habitat.html

Blackson, H. (2012). The five Cs of neighborhood planning. Better Cities and Towns. Retrieved 22 August 2014, from http://bettercities.net/news-opinion/blogs/howard-blackson/18813/ five-cs-neighborhood-planning

Boyer, M (2010). Form or Fluff?: Assessing the Proposed Advantages of Form-Based Codes for Municipalities. Chapel Hill, NC. UNC School of Government, Capstone Project.

Brownson, R., Hoehner, C., Day, K., Forsyth, A., \& Sallis, J. (2009). Measuring the built environment for physical activity: state of the science. American Journal Of Preventive Medicine, 36(4), 99--123.

Buttimer A. (1980). Home, Reach and the Sense of Place. In Buttimer A, Seamon D., Eds., The Human Experience of Space and Place, London, Croom Helm.

Caliskan, O. and Marshall, S. (2011). Urban Morphology and Design: Introduction. Built Environment, 37(4), pp.381-392.

Campoli, J. (2012). Made for walking. Cambridge, Mass.: Lincoln Institute of Land Policy.

Choi, E., \& Sardari Sayyar, S. (2012). Urban Diversity and Pedestrian Behavior, Refining the Concept of Land-Use Mix for Walkability. In Proceedings: Eighth International Space Syntax Symposium (pp. 8073:1-8073:15). Santiago de Chile: PUC.

Choi, E. (2013). Understanding Walkability: Dealing with the Complexity Behind Pedestrian. In Proceedings of the Ninth International Space Syntax Symposium (pp. 107.1-107.14). Seoul: Sejong University.

Clty of Azusa, CA,. (2014). Municode Library. Azusa, CA Development Code, Chapter 88. Retrieved 6 December 2014, from https://www.municode.com/library/ca/azusa/codes/code_of_ ordinances?nodeld=CH88DECO

City of Benicia, CA. (2007). Downtown Mixed Use Master Plan. Ci.benicia.ca.us. Retrieved 23 October 2014, from http://www.ci.benicia.ca.us/index.asp?Type=B_BASIC\&SEC=\{D87C20DD-AE9B-41D5-84A7-D29CAD93E9F3\}

City of Birmingham, MI. (2014). City Codes Ordinances. Retrieved 20 July 2014, from http://www. bhamgov.org/code/index.php 
City of Cincinnati, OH, \& Opticos Design, Inc.,. (2012). Complete Neighborhoods, Citywide FormBased Code Charrette: Summary Report. Cincinnati, OH. Retrieved from http://formbasedcodes.org/content/uploads/2014/07/Cincinnati-FBC_CharretteSummary_070212.pdf

City of Cincinnati,. (2013). Download Plan Cincinnati. Plancincinnati.org. Retrieved 3 November 2014, from http://www.plancincinnati.org/learn/about-plan-cincinnati/download-plan-cincinnati

City of Cincinnati,. (2014). Final Draft of Cincinnati Form-Based Code - City Planning \& Buildings. Cincinnati-oh.gov. Retrieved 29 October 2014, from http://www.cincinnati-oh.gov/planning/ news/final-draft-of-cincinnati-form-based-code/

City of Farmers Branch. (2002). Farmers Branch Station Area Conceptual Master Plan. City of Farmers Branch TX. Retrieved from http://www.farmersbranch.info/ DocumentCenter/View/403

City of Farmers Branch. (2005). Form-Based Code Station Area Ordinance 2800 (1st ed.). City of Farmers Branch, TX: City of Farmers Branch, TX. Retrieved from http://www.farmersbranch. info/DocumentCenter/View/594

City of Hayward, CA. (2011). South Hayward BART Form-Based Code. Hayward-ca.gov. Retrieved 27 October 2014, from http://www.hayward-ca.gov/CITY-GOVERNMENT/SPECIAL-PROJECTS-\&-STUDIES/shbfbc.shtm

City of Peoria, IL,. (2002). Publications. Heart of Peoria Plan. City of Peoria, Illinois. Peoriagov. org. Retrieved 8 November 2014, from http://www.peoriagov.org/community-development/ planning-and-zoning-division/publications/

City of Peoria, IL,. (2008). City of Peoria Zoning District Map. City of Peoria, IL. Retrieved from http://www.homewardgroup.com/uploads/6/8/7/3/6873584/peoria_zoning_map.pdf

City of Peoria, IL. (2014b). Appendix C - Heart of Peoria Land Development Code. Municode. com. Retrieved 8 November 2014, from https://www.municode.com/library/il/peoria/codes/ code_of_ordinances?nodeld=CO_APXCHEPELADECO

City of Portland, \& Portland Bureau of Planning and Sustainability (BPS). (2014). Urban Design and Neighborhood Character. Portlandoregon.gov. Retrieved 1 September 2014, from http:// www.portlandoregon.gov/bps/63897

City of Portland. (2014a). Comprehensive Plan Update (Portland Plan Implementation). Portlandoregon.gov. Retrieved 1 September 2014, from http://www.portlandoregon.gov/bps/57352

City of Portland. (2014b). My Portland Plan: What Makes a Neighborhood Complete?. Portlandonline.com. Retrieved 15 October 2014, from http://www.portlandonline.com/portlandplan/ index.cfm? $a=437441 \& c=50730$

City of Portland, OR. (2014c). Urban Design and Neighborhood Character, Centers: Anchors to Complete Neighborhoods. Retrieved August 31, 2014, from http://www.portlandoregon.gov/bps/63897

City of Portland. (2014d). 20-Minute Neighborhoods. Portlandonline.com. Retrieved 11 December 2014, from http://www.portlandonline.com/portlandplan/index.cfm?a=288098\&c=52256

Chen, W. (2008). Neighborhood Scale and Market-Responsive Urban Design (PhD Dissertation). University of Hong Kong.

Chicago Metropolitan Agency for Planning,. (2014). Form-Based Codes. Cmap.illinois. gov. Retrieved 13 March 2014, from http://www.cmap.illinois.gov/livability/land-usezoning/form-based-codes 
Congress for the New Urbanism. (2010). Form-Based Codes in 7 Steps. Milford, MI: Michigan Chapter CNU.

Congress for New Urbanism. (2012). CNU 20 - Looking Forward: New Urbanism and the New World. Retrieved from https://www.youtube.com/watch?v=i6kO09blq34

Congress for the New Urbanism (CNU). (2011). Charter of the New Urbanism. Cnu.org. Retrieved 18 December 2014, from http://www.cnu.org/charter

Duany, A. \& Plater-Zyberk, E. 1995, "Neighborhoods and suburbs," Design Quarterly no. 164, p. 10.

Duany Plater-Zyberk \& Company. (2014). Seaside. Retrieved July 26, 2014, from http://www. dpz.com/Projects/7903

Duany, A., Sorlein, S., \& Wright, W. (2008). Smartcode version 9.2. New Urban News Publications.

Evans, Q. (2009). The SmartCode: Understanding a Modern Zoning Trend. For the Defense, 51(10), pp.22-25.

Emerson, C. D. (2006). Making Main Street Legal Again: The Smart-Code Solution to Sprawl. Columbia, MO, Missouri Law Review, 71, pp.637-645

Environmental Protection Agency (EPA). (2014). Location. Epa.gov. Retrieved 11 December 2014, from http://www.epa.gov/smartgrowth/topics/location.html

Environmental Protection Agency (EPA). (2014). About Smart Growth. Epa.gov. Retrieved 11 December 2014, from http://www.epa.gov/smartgrowth/about_sg.htm

Ewing, R., \& Cervero, R. (2010). Travel and the built environment: a meta-analysis. Journal Of The American Planning Association, 76(3), 265--294.

Ferrell Madden Lewis,. (2014). Heart of Peoria. Ferrell-Madden. Retrieved 7 November 2014 , from http://www.ferrell-madden.com/Peoria.php

Fischel, W. (1985). The Economics of zoning laws. Baltimore [etc.]: The John Hopkins University Press.

Form-Based Codes Institute. (2014a). Form-Based Codes Defined - Form-Based Codes Institute. Retrieved 19 July 2014, from http://formbasedcodes.org/definition

Form-Based Codes Institute. (2014b). Library of Codes - Form-Based Codes Institute. Retrieved 19 July 2014, from http://formbasedcodes.org/codes

Form-Based Codes Institute. (2014c). Identifying \& Evaluating Form-Based Codes Form-Based Codes Institute. Retrieved 19 July 2014, from http://formbasedcodes.org/ identifying-evaluating

Form-Based Code Institute,. (2014d). Driehaus Form-Based Codes Award - Form-Based Codes Institute. Form-Based Codes Institute. Retrieved 21 October 2014, from http://formbasedcodes.org/driehaus-award

Freestone, R. (2001). Urban Planning (Western), History of. In N. Smelser \& P. Baltes, International Encyclopedia of the Social \& Behavioral Sciences (1st ed., pp. 16058-16063). Amsterdam: Elsevier. Retrieved from http://www.krivda.net/books/-international_encyclopedia_of_ the_social_and_behavioral_sciences_11_-_urban_planning_western_history_of_541 
Glaserworks. (2014). Urban Design/Planing - Form-Based Codes. Retrieved 16 December 2014, from http://www.glaserworks.com/www3/urbciv/formbasedcode/welcome.shtml

Glazier, R., Creatore, M., Weyman, J., Fazli, G., Matheson, F., \& Gozdyra, P. et al. (2014). Density, Destinations or Both? A Comparison of Measures of Walkability in Relation to Transportation Behaviors, Obesity and Diabetes in Toronto, Canada. Plos ONE, 9(1), e85295. doi:10.1371/journal.pone.0085295

Goetz, E., (2004). The big tent of growth management: smart growth as a movement. In: Bengston, David N., Tech. Ed. 2005. Policies for Managing Urban Growth And Landscape Change: A Key To Conservation In The 21St Century. Gen. Tech. Rep. NC-265. St. Paul, MN: U.S. Department Of Agriculture, Forest Service, North Central Research Station. 51 P., 45.

Gowdy, M. L. (2009). A History, Evolution and Application of Form-Based Codes. Unpublished report, Kansas State University, Department of Landscape Architecture/Regional and Community Planning, Manhattan, KS.

Howard, E., \& Osborn, F. (1965). Garden cities of to-morrow. Cambridge, Mass.: M.I.T. Press.

Inniss, L. (2007). Back to the Future: Is Form-Based Code an Efficacious Tool for Shaping Modern Civic Life. U. Pa. JL I\& Soc. Change, 11, 75.

Jacobs, J. (1961). The Death and Life of Great American Cities. New York: Random House.

Jane's Walk,. (2014). What is Walkability?. Retrieved 9 October 2014, from http://www.janeswalk. org/information/resources/walkability

Johnson, P. (1994). The theory of architecture (1st ed.). New York: Van Nostrand Reinhold.

Jones, E. (2009). Optimizing Urban Structure: Towards an Integrated New Urbanist Model. Presentation, CNU Event 17, June 2009.

Katz, P., Scully, V., \& Bressi, T. (1994). The new urbanism. New York: McGraw-Hill.

Kelbaugh, D. (1989). The Pedestrian pocket book: a new suburban design strategy. New York, NY: Princeton Architectural Press in association with the University of Washington.

Krier, R. (1979). Urban space (1st ed.). New York: Rizzoli International Publications.

Kruger, D. (2008). Verifying the operational definition of neighborhood for the psychosocial impact of structural deterioration. Journal Of Community Psychology, 36(1), 53--60.

Lavey, J., \& Hill, J. (2014a). What is walkability?. Community Builders. Retrieved 29 August 2014, from http://communitybuilders.net/walkability/

Lavey, J., \& Hill, J. (2014b). Walkability 201: An Expanded Look. Community Builders. Retrieved 29 August 2014, from http://communitybuilders.net/walkability-201-expanded-look/

Lee County, FL. (2014). Lee County Land Development Code (LDC), Chapter 32 - COMPACT COMMUNITIES. http://www.leegov.com. Retrieved 17 October 2014, from http://www.leegov. com/gov/dept/dcd/zoning/Pages/LDC.aspx

L.G.C. (Local Government Commission). (2014). Original Ahwahnee Principles - Local Government Commission. Retrieved 17 July 2014, from http://www.lgc.org/about/ahwahnee/principles?f=ahwahnee/ principles.html

Lynch, K. (1976). Managing the Sense of a Region. Cambridge, Mass: MIT Press. 
Lynch, K. (1984). Good City Form. MIT Press, Cambridge, Mass.

Mandelker, D., Cunningham, R., \& Payne, J. (2012). Planning and control of land development (8th ed.). Charlottesville, Va.: Michie Co.

Mayne, D., Morgan, G., Willmore, A., Rose, N., Jalaludin, B., Bambrick, H., \& Bauman, A. (2013). An objective index of walkability for research and planning in the Sydney Metropolitan Region of New South Wales, Australia: an ecological study. International Journal Of Health Geographics, 12(1), 61.

Meck, S. (1996). Model Planning and Zoning Enabling Legislation: A Short History. Modernizing State Planning Statutes: The Growing Smart Working Papers, Volume 1. Planning Advisory Report Number 462/463. Chicago: American Planning Association, pp.1-17.

Mehaffy, M., Porta, S., Rofe, Y., \& Salingaros, N. (2010). Urban nuclei and the geometry of streets: The 'emergent neighborhoods' model. Urban Design International, 15(1), 22--46.

Mehaffy, M. (2011). Assessing and Promoting Walkable Development on the Phoenix Light Rail Corridor. Phoenix, AZ: Arizona State University.

Mehaffy, M. (2014). The new relevance of New Urbanism. Bettercities.net. Retrieved 22 July 2014, from http://bettercities.net/news-opinion/blogs/michael-mehaffy/15771/ new-relevance-new-urbanism

Mehaffy, M., Porta, S., \& Romice, O. (2014). The "neighborhood unit" on trial: a case study in the impacts of urban morphology. Journal Of Urbanism: International Research On Placemaking And Urban Sustainability, 1-19. doi:10.1080/17549175.2014.908786

Menard, J. (2009). The SmartCode | Congress for the New Urbanism. Cnu.org. Retrieved 20 June 2014, from http://www.cnu.org/resources/projects/smartcode-2009.

Mixon, J., Dougherty Jr., J., \& McDonald, B. (2013). Texas Municipal Zoning Law (3rd ed., Chapter 3, Section 3.310). Lexis Nexis Matthew Bender.

Morris, M. (editor). (2009). SmartCodes: Model Land-Development Regulations. Chicago, IL, American Planning Association. Planning Advisory Service Report 356.

Murrain, P. (2009). Successful Places for the 21St Century. Presentation at Urban Design Summer School, Bristol, GB. Retrieved from: http://webarchive.nationalarchives.gov. uk/20110118095356/http:/www.cabe.org.uk/urban-design-summer-school/2009

Nelson, K. (2012). Essential Smart Growth Fixes for Rural Planning, Zoning, and Development Codes. United States Environmental Protection Agency (EPA). Retrieved from http://www.epa. gov/smartgrowth/pdf/rural_essential_fixes_508_030612.pdf

Norberg-Schulz C. (1980). Genius Loci: Towards a Phenomenology of Architecture. New York: Rizzoli International Publications Inc.

Olson, J. (2013). The Neighborhood Unit: How Does Perry's Concept Apply to Modern Day Planning?. [online] EVstudio, Architect Engineer Denver Evergreen Colorado, Austin Texas Architect. Available at: http://evstudio.com/the-neighborhood-unit-how-does-perrys-concept-applyto-modern-day-planning/

Parolek, D., Parolek, K., \& Crawford, P. (2008). Form-Based Codes. Hoboken, N.J.: J. Wiley \& Sons.

Perez, T. (2014). Form-Based vs Conventional Zoning. Chicago: Opticos Design, Inc. Retrieved from http://www.cmap.illinois.gov/livability/land-use-zoning/form-based-codes 
Perry, C. (1929). Neighborhood and community planning (1st ed.). New York: Regional plan of New York and its environs.

Planning.org. (2010). Urban Morphology. Retrieved 24 July 2014, from https://www.planning.org/ tuesdaysatapa/2010/aug.htm

Plater-Zyberk E. (2008). Forward. Parolek P., Parolek D., Parolek K. (p. ix). Form-Based Codes: A Guide to Planners, Urban Designers, Municipalities, and Developers. Hoboken, NJ: John Wiley \& Sons, Inc.

Polyzoides, S., \& Moule, E. (2005). Streets, Blocks \& Buildings | Moule \& Polyzoides. Mparchitects.com. Retrieved 8 October 2014, from http://www.mparchitects.com/site/thoughts/ streets-blocks-buildings

Polyzoides, Stefanos (2008). Forward. Parolek P., Parolek D., Parolek K. (p. ix). Form-Based Codes: A Guide to Planners, Urban Designers, Municipalities, and Developers. Hoboken, NJ: John Wiley \& Sons, Inc.

Principle. (2014). Dictionary.com. Retrieved July 26, 2014, from http://dictionary.reference. com/browse/principle

Project for Public Spaces,. (2011). What is Walkability? How Do You Measure It? Take-Aways from This Year's TRB Meeting. Pps.org. Retrieved 29 August 2014, from http://www.pps.org/ blog/what-is-walkability-how-do-you-measure-it-take-aways-from-this-years-trb-meeting/

Psychologistworld.com. (2014). Behavioral Approach. Retrieved 24 July 2014, from http://www. psychologistworld.com/issues/behavioralapproach.php

Rattan, A., Campese, A., \& Eden, C. (2012). Modeling Walkability. Esri.com. Retrieved 9 October 2014, from http://www.esri.com/news/arcuser/0112/modeling-walkability.html

Real Estate Research Corporation. (1974). The Co\$ts of Sprawl, Executive Summary (1st ed.). Washington, D.C.: Superintendent of Documents, U.S. Government Printing Office Washington, D.C. 20402 -Stock Number 041-011-00023-8 Catalog Number PREX 14.2:SP/2/summ. Retrieved from http://www.smartgrowth.org/pdf/costs_of_sprawl.pdf

Relph, E. (1976). Place and Placelessness. London, UK, Pion Ltd.

Repps, J. (2014). Olmsted, a City Planning Program. Proceedings of the Fifth National Conference on City Planning (Boston, 1913):1-16. Urbanplanning.library.cornell.edu. Retrieved 23 June 2014, from http://urbanplanning.library.cornell.edu/DOCS/olmst_13.htm

Salden, S. (2014a). The Seaside Code. Retrieved July 26, 2014, from https://seaside.library. nd.edu/essays/the-code

Salden, S. (2014b). The Seaside Plan. Retrieved July 26, 2014, from https://seaside.library. nd.edu/essays/the-plan

Seamon, D. (1980). Afterword: Community, Place, and Environment. In Buttimer A., Seamon D., Eds. The Human Experience of Space and Place. London: Croom Helm.

Seaside Institute. (2014a). About Seaside. Retrieved 14 October 2014, from http://www.seasideinstitute.org/whoweare.

Seaside Institute,. (2014b). What We Do. Retrieved 26 July 2014, from http://seasideinstitute.org/what-we-do/ 
Smart Growth Network. (n.d.). Smart Growth Online. Retrieved July 27, 2014, from http://www. smartgrowth.org/network.php

St Lucie County, \& Treasure Coast Regional Planning Council. (2004). North St. Lucie County Charrette. Treasure Coast Regional Planning Council. Retrieved from http://www.tcrpc.org/ departments/studio/st_lucie_charrette/st_lucie_final_report.pdf

St Lucie County, \& Treasure Coast Regional Planning Council. (2006). Towns, Villages and the Countryside A New Pattern of Settlement for North St. Lucie County. Treasure Coast Regional Planning Council. Retrieved from http://www.tcrpc.org/departments/studio/st_lucie_charrette/tvc_element.pdf

St Lucie County. (2006). Ordinance No. 06-017. St. Lucie County \& Treasure Coast Regional Planning Council. Retrieved from http://www.tcrpc.org/departments/studio/st_lucie charrette/ldrs adopted.pdf?DocumentID=1205345\&FolderID=1203216\&SearchḦan$\mathrm{dle}=0$ \&DocView $\bar{T}$ ype=Showlmage\&LeftPaneType=Hidden\&dbid=14\&page $=1$

Steg, L., Berg, A., \& de Groot, J. (2013). Environmental psychology (1st ed.). Chichester, West Sussex: Wiley-Blackwell.

Steil, L., Salingaros, N., \& Mehaffy, M. (2008). Growing Sustainable Suburbs: An Incremental Strategy for Reconstructing Sprawl. In T. Haas, New Urbanism \& Beyond: Contemporary and Future Trends in Urban Design (1st ed.). New York: Rizzoli International Publications.

Stokols, D. (2014). Lecture 12 - Applying Environmental Psychology Principles to Urban Design. Retrieved from http://www.youtube.com/watch?v=QYrINvhRjTY

Talen, E. (2009). Design By The Rules: The Historical Underpinnings of Form-Based Codes. Journal of the American Planning Association, 75(2), 144-160.

Talen E. (2012). City Rules, How Regulations Affect City Form. Washington, DC. Island Press.

Tehachapi General Plan. (2012) (1st ed.). Tehachapi, CA. Retrieved from http://www.liveuptehachapi.com/DocumentCenter/View/2190

Thorpe, D. (2014). The 12 Rules of Sustainable Urbanism. Sustainable Cities Collective. Retrieved 22 August 2014, from http://sustainablecitiescollective.com/david-thorpe/239556/12-ru les-sustainable-urbanism

Town Paper,. (2014). TND Neighborhoods. Retrieved 26 July 2014, from http://www.tndtownpaper. com/neighborhoods.htm

Tuan Yi-Fu. (1984). In Place Out of Place. Geoscience \& Man, 24, 3-10.

Urban Design Compendium. (2013). Homes and Communities Agency. Retrieved July 26, 2014, from http://www.homesandcommunities.co.uk/urban-design-compendium?page_id $=5542 \&$ page $=203$

Urban Design. (n.d.). Urban Design. Retrieved July 26, 2014, from http://www.urbandesign. org/urbandesign.html

Walkable Communities, Inc,. (2014). Walkable Communities. Retrieved 4 November 2014, from http://www.walkable.org/index.html

WalkScore. (2014). What Makes a Neighborhood Walkable. Walkscore.com. Retrieved 29 August 2014, from http://www.walkscore.com/walkable-neighborhoods.shtml 


\section{APPENDICES}

Appendix I: Ahwahnee Principles

\section{Ahwahnee Community Principles}

The 15 Ahwahnee Community Principles according to the Local Government Commission (2014) are:

1. All planning should be in the form of complete and integrated communities containing housing, shops, work places, schools, parks and civic facilities essential to the daily life of the residents.

2. Community size should be designed so that housing, jobs, daily needs and other activities are within easy walking distance of each other.

3. As many activities as possible should be located within easy walking distance of transit stops.

4. A community should contain a diversity of housing types to enable citizens from a wide range of economic levels and age groups to live within its boundaries.

5. Businesses within the community should provide a range of job types for the community's residents.

6. The location and character of the community should be consistent with a larger transit network.

7. The community should have a center focus that combines commercial, civic, cultural and recreational uses. 
8. The community should contain an ample supply of specialized open space in the form of squares, greens and parks whose frequent use is encouraged through placement and design.

9. Public spaces should be designed to encourage the attention and presence of people at all hours of the day and night.

10. Each community or cluster of communities should have a well-defined edge, such as agricultural green-belts or wildlife corridors, permanently protected from development.

11. Streets, pedestrian paths and bike paths should contribute to a system of fully-connected and interesting routes to all destinations. Their design should encourage pedestrian and bicycle use by being small and spatially defined by buildings, trees and lighting; and by discouraging high speed traffic.

12. Wherever possible, the natural terrain, drainage and vegetation of the community should be preserved with superior examples contained within parks or greenbelts.

13. The community design should help conserve resources and minimize waste.

14. Communities should provide for the efficient use of water through the use of natural drainage, drought tolerant landscaping and recycling.

15. The street orientation, the placement of buildings and the use of shading should contribute to the energy efficiency of the community.

\section{Ahwahnee Regional Principles}

The 4 Ahwahnee Regional Principles, according to the Local Government Commission, (2014) are:

1. The regional land-use planning structure should be integrated within a larger transportation network built around transit rather than freeways. 
2. Regions should be bounded by and provide a continuous system of greenbelt/wildlife corridors to be determined by natural conditions.

3. Regional institutions and services (government, stadiums, museums, etc.) should be located in the urban core.

4. Materials and methods of construction should be specific to the region, exhibiting a continuity of history and culture and compatibility with the climate to encourage the development of local character and community identity. 
The Smart Growth Principles (Smart Growth Network, n.d.).are:

1. Mix land uses

2. Take advantage of compact building design

3. Create a range of housing opportunities and choices

4. Create walkable neighborhoods

5. Foster distinctive, attractive communities with a strong sense of place

6. Preserve open space, farmland, natural beauty and critical environmental areas

7. Strengthen and direct development towards existing communities

8. Provide a variety of transportation choices

9. Make development decisions predictable, fair and cost effective

10. Encourage community and stakeholder collaboration in development decisions

Smart Growth guidelines also endorse new town centers because they provide "a high quality of life, housing and transportation choices affordable for people with a range of incomes, many opportunities for social interaction, and cost-effective infrastructure and services" (Nelson, 2012, p. 6).

Although no on the list of Smart Growth principles proximity to daily needs is addressed through the concept of location efficient siting:

location-efficient siting, or locating a building within or near an existing community, is a smart growth strategy that connects particularly well with green building practices. Location is a crucial component of green building, as how people and goods get to and from the site affects the environmental performance of the building and its occupants. 
Using smart growth principles and strategies can reduce the environmental impacts of buildings and development and enhance a community's health and economy by offering a range of housing and transportation options and putting a mix of uses close together. These strategies help communities protect the natural environment by using resources more efficiently and making it easier for people to drive less if they choose. Location-efficient siting also results in less impervious surface per unit of development. Coupled with green building techniques that capture and filter rainwater, it can reduce polluted stormwater runoff, and make neighborhoods more attractive, economically stronger, and more socially diverse. (Environmental Protection Agency (EPA), 2014, Section: Smart Growth Principles) 
The following is a listing of select principles from the Charter of New Urbanism (Congress for the New Urbanism (CNU), 2011) directly affecting urban form. Appendix IV lists all CNU principles.

For the region, similar to the Ahwahnee Principles, CNU advocates for:

- Clearly defined geographical boundaries of regions derived from natural features.

- Multiple centers for the metropolis such as cities, towns and villages.

- Identifiable center, distinct edges.

- Respect for historic patterns.

- Organization of settlements into neighborhoods, districts or towns and villages if adjacent to urban boundaries.

- Distinct edges for development patterns are emphasized repeatedly.

- Transportation alternatives with emphasis on transit, bicycle and pedestrian circulation to reduce dependency on the automobile.

For the neighborhood, the district, and the corridor CNU recommends:

- Following the principles of neighborhood design.

- Creating areas compact.

- Pedestrian friendly.

- Mixture of uses within walking distance for the residents.

- Utilizing a network of interconnected streets to encourage walking.

- Variation of housing types. 
- Walking distance from transit stops.

- Concentration of civic, institutional and commercial activity.

- Availability of parks within neighborhoods.

- Conservation areas or open lands forming the boundaries of neighborhoods.

Finally for the block, the street and the building CNU emphasizes:

- Physical definition of streets.

- Respect for the pedestrian and the form of public space.

- Streets that encourage walking and are interesting to the pedestrian.

- Architecture and design drawing from local aspects.

- Placement of civic buildings and gathering places in important sites.

- Preservation and renewal of historic districts. 
The Congress for the New Urbanism views disinvestment in central cities, the spread of placeless sprawl, increasing separation by race and income, environmental deterioration, loss of agricultural lands and wilderness, and the erosion of society's built heritage as one interrelated community-building challenge. CNU's principles are (Congress for the New Urbanism (CNU), 2011):

- We stand for the restoration of existing urban centers and towns within coherent metropolitan regions, the reconfiguration of sprawling suburbs into communities of real neighborhoods and diverse districts, the conservation of natural environments, and the preservation of our built legacy.

- We recognize that physical solutions by themselves will not solve social and economic problems, but neither can economic vitality, community stability, and environmental health be sustained without a coherent and supportive physical framework.

- We advocate the restructuring of public policy and development practices to support the following principles: neighborhoods should be diverse in use and population; communities should be designed for the pedestrian and transit as well as the car; cities and towns should be shaped by physically defined and universally accessible public spaces and community institutions; urban places should be framed by architecture and landscape design that celebrate local history, climate, ecology, and building practice.

- We represent a broad-based citizenry, composed of public and private sector leaders, community activists, and multidisciplinary professionals. We are committed to reestablishing the relationship between the art of building and the making of community, through citizen-based participatory planning and design. 
- We dedicate ourselves to reclaiming our homes, blocks, streets, parks, neighborhoods, districts, towns, cities, regions, and environment.

- We assert the following principles to guide public policy, development practice, urban planning, and design:

\section{THE REGION: METROPOLIS, CITY, AND TOWN}

1. Metropolitan regions are finite places with geographic boundaries derived from topography, watersheds, coastlines, farmlands, regional parks, and river basins. The metropolis is made of multiple centers that are cities, towns, and villages, each with its own identifiable center and edges.

2. The metropolitan region is a fundamental economic unit of the contemporary world. Governmental cooperation, public policy, physical planning, and economic strategies must reflect this new reality.

3. The metropolis has a necessary and fragile relationship to its agrarian hinterland and natural landscapes. The relationship is environmental, economic, and cultural. Farmland and nature are as important to the metropolis as the garden is to the house.

4. Development patterns should not blur or eradicate the edges of the metropolis. Infill development within existing urban areas conserves environmental resources, economic investment, and social fabric, while reclaiming marginal and abandoned areas. Metropolitan regions should develop strategies to encourage such infill development over peripheral expansion.

5. Where appropriate, new development contiguous to urban boundaries should be organized as neighborhoods and districts, and be integrated with the existing urban pattern. 
Noncontiguous development should be organized as towns and villages with their own urban edges, and planned for a jobs/housing balance, not as bedroom suburbs.

6. The development and redevelopment of towns and cities should respect historical patterns, precedents, and boundaries.

7. Cities and towns should bring into proximity a broad spectrum of public and private uses to support a regional economy that benefits people of all incomes. Affordable housing should be distributed throughout the region to match job opportunities and to avoid concentrations of poverty.

8. The physical organization of the region should be supported by a framework of transportation alternatives. Transit, pedestrian, and bicycle systems should maximize access and mobility throughout the region while reducing dependence upon the automobile.

9. Revenues and resources can be shared more cooperatively among the municipalities and centers within regions to avoid destructive competition for tax base and to promote rational coordination of transportation, recreation, public services, housing, and community institutions.

\section{THE NEIGHBORHOOD, THE DISTRICT, AND THE CORRIDOR}

1. The neighborhood, the district, and the corridor are the essential elements of development and redevelopment in the metropolis. They form identifiable areas that encourage citizens to take responsibility for their maintenance and evolution.

2. Neighborhoods should be compact, pedestrian-friendly, and mixed-use. Districts generally emphasize a special single use, and should follow the principles of neighborhood 
design when possible. Corridors are regional connectors of neighborhoods and districts; they range from boulevards and rail lines to rivers and parkways.

3. Many activities of daily living should occur within walking distance, allowing independence to those who do not drive, especially the elderly and the young. Interconnected networks of streets should be designed to encourage walking, reduce the number and length of automobile trips, and conserve energy.

4. Within neighborhoods, a broad range of housing types and price levels can bring people of diverse ages, races, and incomes into daily interaction, strengthening the personal and civic bonds essential to an authentic community.

5. Transit corridors, when properly planned and coordinated, can help organize metropolitan structure and revitalize urban centers. In contrast, highway corridors should not displace investment from existing centers.

6. Appropriate building densities and land uses should be within walking distance of transit stops, permitting public transit to become a viable alternative to the automobile.

7. Concentrations of civic, institutional, and commercial activity should be embedded in neighborhoods and districts, not isolated in remote, single-use complexes. Schools should be sized and located to enable children to walk or bicycle to them.

8. The economic health and harmonious evolution of neighborhoods, districts, and corridors can be improved through graphic urban design codes that serve as predictable guides for change.

Charter for the New Urbanism Appendix E- 2 Florida Planning Officials Handbook 
9. A range of parks, from tot-lots and village greens to ballfields and community gardens, should be distributed within neighborhoods. Conservation areas and open lands should be used to define and connect different neighborhoods and districts.

\section{THE BLOCK, THE STREET, AND THE BUILDING}

1. A primary task of all urban architecture and landscape design is the physical definition of streets and public spaces as places of shared use.

2. Individual architectural projects should be seamlessly linked to their surroundings. This issue transcends style.

3. The revitalization of urban places depends on safety and security. The design of streets and buildings should reinforce safe environments, but not at the expense of accessibility and openness.

4. In the contemporary metropolis, development must adequately accommodate automobiles. It should do so in ways that respect the pedestrian and the form of public space.

5. Streets and squares should be safe, comfortable, and interesting to the pedestrian. Properly configured, they encourage walking and enable neighbors to know each other and protect their communities.

6. Architecture and landscape design should grow from local climate, topography, history, and building practice.

7. Civic buildings and public gathering places require important sites to reinforce community identity and the culture of democracy. They deserve distinctive form, because their role is different from that of other buildings and places that constitute the fabric of the city. 
8. All buildings should provide their inhabitants with a clear sense of location, weather and time. Natural methods of heating and cooling can be more resource-efficient than mechanical systems.

9. Preservation and renewal of historic buildings, districts, and landscapes affirm the continuity and evolution of urban society. 
Table 29 lists walkability parameters identified by author. Table 2, in the main text, re-organizes parameters under the 5Ds and similar parameters listed by multiple authors are omitted.

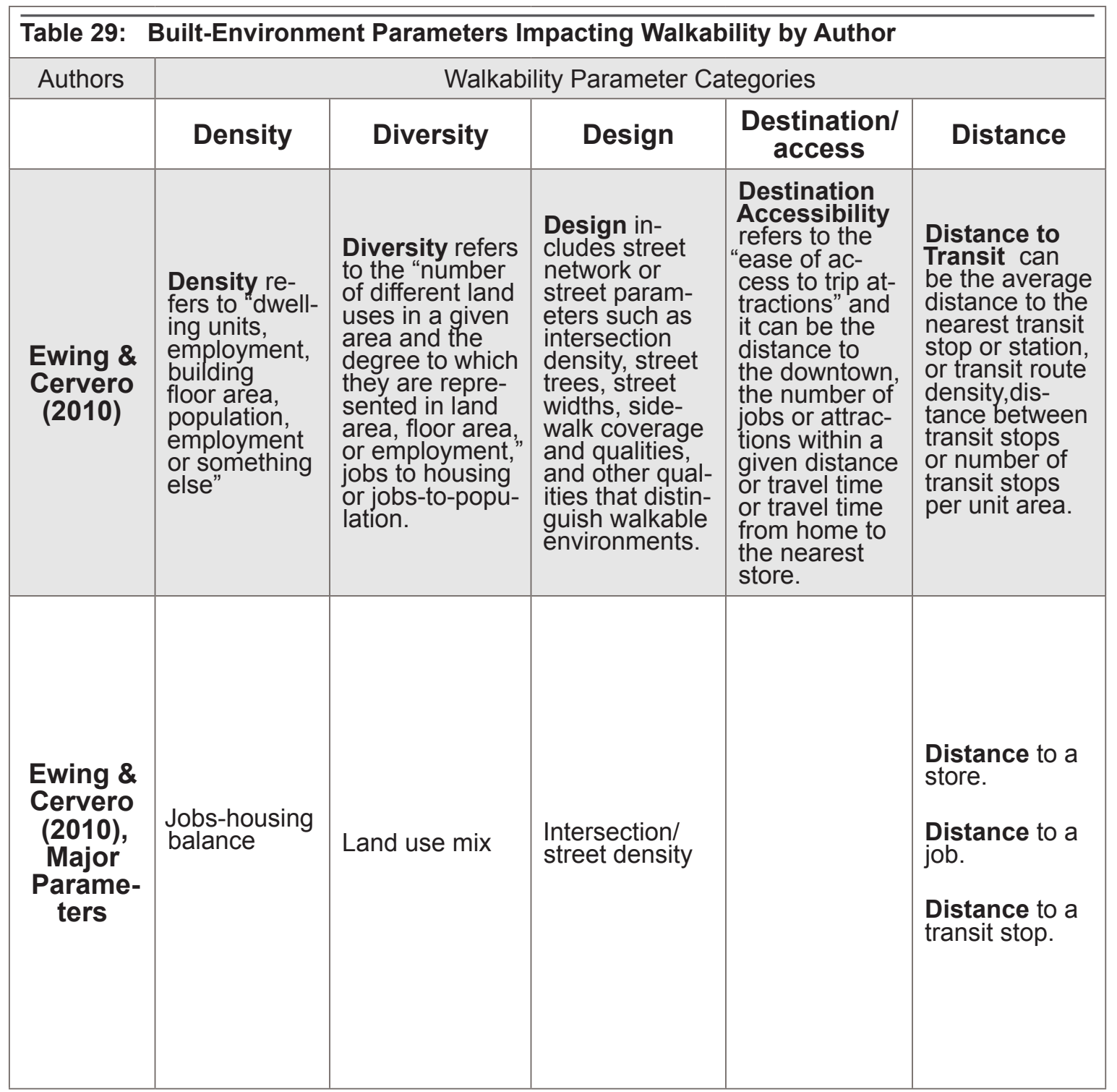




\begin{tabular}{|c|c|c|c|c|c|}
\hline \multirow[t]{2}{*}{ Authors } & \multicolumn{5}{|c|}{ Walkability Parameter Categories } \\
\hline & Density & Diversity & Design & $\begin{array}{l}\text { Destination/ } \\
\text { access }\end{array}$ & Distance \\
\hline $\begin{array}{c}\text { Lavey } \\
\text { \& Hill } \\
\text { (2014a), } \\
\text { the 3Ps }\end{array}$ & & $\begin{array}{l}\text { Places refers } \\
\text { to the presence } \\
\text { of a mix of des- } \\
\text { tinations "pro- } \\
\text { viding enough } \\
\text { diversity so that } \\
\text { people have } \\
\text { the oppoortu- } \\
\text { nity to fulfill at } \\
\text { least some of } \\
\text { their daily and } \\
\text { weekly needs" } \\
\text { (Lavey \& Hill, } \\
2014 a, \text { Section } \\
\text { Places to Go, } \\
\text { Para. } 1 \text { ). Such } \\
\text { destinations } \\
\text { are workplac- } \\
\text { es, corner } \\
\text { stores/markets, } \\
\text { schools, restau- } \\
\text { rants, retail, } \\
\text { public spaces, } \\
\text { parks, transit } \\
\text { stops, and cul- } \\
\text { ture such as } \\
\text { museums and } \\
\text { music venues. } \\
\text { Lavey adds } \\
\text { that the more } \\
\text { places there } \\
\text { are, the more } \\
\text { the opportu- } \\
\text { nities for local } \\
\text { residents to } \\
\text { fulfill their basic } \\
\text { daily needs on } \\
\text { foot. }\end{array}$ & & $\begin{array}{l}\text { Physical } \\
\text { Access } \\
\text { translates } \\
\text { to adequate } \\
\text { infrastructure } \\
\text { to facilitate } \\
\text { walking, such } \\
\text { as safe and } \\
\text { comfortable } \\
\text { sidewalks and } \\
\text { pedestrian } \\
\text { friendly inter- } \\
\text { sections. }\end{array}$ & $\begin{array}{l}\text { Proximity re- } \\
\text { fers to the } 10 \\
\text { or } 15 \text { minute } \\
\text { walk pedes- } \\
\text { trians are } \\
\text { usually willing } \\
\text { to walk before } \\
\text { changing the } \\
\text { mode of trans- } \\
\text { portation. This } \\
\text { represents a } \\
1 / 4 \text { to } 1 / 5 \text { mile } \\
\text { radius from } \\
\text { home to key } \\
\text { destinations. }\end{array}$ \\
\hline $\begin{array}{c}\text { Lavey } \\
\text { \& Hill } \\
\text { (2014b), } \\
\text { the 5Ds }\end{array}$ & $\begin{array}{l}\text { Density: } \\
\text { There ore } \\
\text { many attrac- } \\
\text { tions/ame- } \\
\text { nities close } \\
\text { together so } \\
\text { that you can } \\
\text { run several } \\
\text { errands in a } \\
\text { single trip on } \\
\text { foot. }\end{array}$ & $\begin{array}{l}\text { Diversty: } \\
\text { There is a } \\
\text { diversity of } \\
\text { housing options } \\
\text { and a diversity } \\
\text { of places to go- } \\
\text { this includes } \\
\text { parks, restau- } \\
\text { rants, shops, } \\
\text { trails, etc. }\end{array}$ & $\begin{array}{l}\text { Design: The } \\
\text { neighborhood } \\
\text { is designed for } \\
\text { people as well } \\
\text { as automo- } \\
\text { biles; building } \\
\text { entrances are } \\
\text { oriented to the } \\
\text { street and part- } \\
\text { ing lots are be- } \\
\text { hind buildings. }\end{array}$ & $\begin{array}{l}\text { Destination- } \\
\text { There are } \\
\text { places to go } \\
\text { that are open } \\
\text { for business } \\
\text { and provide } \\
\text { services to } \\
\text { residents. }\end{array}$ & $\begin{array}{l}\text { Distance- At- } \\
\text { tractions ore } \\
\text { close enough } \\
\text { that it is rea- } \\
\text { sonable to } \\
\text { walk to them. }\end{array}$ \\
\hline $\begin{array}{l}\text { Glazier } \\
\text { et al. } \\
\text { (2014) }\end{array}$ & $\begin{array}{l}\text { Population } \\
\text { density as } \\
\text { population } \\
\text { per km2. } \\
\\
\text { Residential } \\
\text { density as } \\
\text { residences } \\
\text { per km2. }\end{array}$ & & $\begin{array}{l}\text { Intersection } \\
\text { density }\end{array}$ & $\begin{array}{l}\text { Destinations } \\
\text { as the sum } \\
\text { of retail and } \\
\text { businesses } \\
\text { including rec- } \\
\text { reation and } \\
\text { schools within } \\
800 \text { meters or } \\
.5 \text { miles. }\end{array}$ & \\
\hline
\end{tabular}




\begin{tabular}{|c|c|c|c|c|c|}
\hline \multirow[t]{2}{*}{ Authors } & \multicolumn{5}{|c|}{ Walkability Parameter Categories } \\
\hline & Density & Diversity & Design & $\begin{array}{l}\text { Destination/ } \\
\text { access }\end{array}$ & Distance \\
\hline $\begin{array}{l}\text { Rattan, } \\
\text { Camp- } \\
\text { ese \& } \\
\text { Eden, } \\
\text { (2012) }\end{array}$ & $\begin{array}{l}\text { Density: } \\
\text { Residential } \\
\text { population } \\
\text { density \& job } \\
\text { density. }\end{array}$ & $\begin{array}{l}\text { Diversity: } \\
\text { percentage } \\
\text { of residents } \\
\text { within walking } \\
\text { distance of } \\
\text { defined diverse } \\
\text { uses that pro- } \\
\text { vide a measure } \\
\text { of mixed-used } \\
\text { development. }\end{array}$ & $\begin{array}{l}\text { Design: Quan- } \\
\text { tified as trail } \\
\text { availability per } \\
1,000 \text { residents, } \\
\text { bicycle path } \\
\text { availability per } \\
100 \text { residents, } \\
\text { and the num- } \\
\text { ber of intersec- } \\
\text { tions per km2. }\end{array}$ & & \\
\hline $\begin{array}{l}\text { "State of } \\
\text { Place" } \\
\text { (Alfonzo, } \\
\text { 2012) }\end{array}$ & $\begin{array}{l}\text { Density as } \\
\text { a measure } \\
\text { of enclosure } \\
\text { based on } \\
\text { building con- } \\
\text { centrations } \\
\text { and height. }\end{array}$ & & $\begin{array}{l}\text { Connectivity } \\
\text { as a measure } \\
\text { of the pres- } \\
\text { ence of barri- } \\
\text { ers such as six } \\
\text { lane roads. } \\
\text { Form as a } \\
\text { measure of } \\
\text { streetscape } \\
\text { discontinuity. }\end{array}$ & $\begin{array}{l}\text { Pedestrian } \\
\text { Infrastruc- } \\
\text { ture/Ameni- } \\
\text { ties such as } \\
\text { curbcuts, side- } \\
\text { walks, street } \\
\text { furniture, and } \\
\text { bike racks. } \\
\text { Traffic mea- } \\
\text { sures such as } \\
\text { traffic signals, } \\
\text { speed limits, } \\
\text { and traffic } \\
\text { calming. } \\
\\
\text { Parks \& pub- } \\
\text { lic spaces } \\
\text { Recreational } \\
\text { facilities such } \\
\text { as gym/fitness } \\
\text { facilities, and } \\
\text { other recre- } \\
\text { ational uses. } \\
\\
\text { Personal } \\
\text { Safety such } \\
\text { as litter, graf- } \\
\text { fiti, windows } \\
\text { with bars. } \\
\text { Aesthetics } \\
\text { such as at- } \\
\text { tractiveness, } \\
\text { open views, } \\
\text { outdoor dining, } \\
\text { maintenance. }\end{array}$ & $\begin{array}{l}\text { Proximity as } \\
\text { a measure of } \\
\text { the presence } \\
\text { non-residential } \\
\text { land uses. }\end{array}$ \\
\hline
\end{tabular}




\begin{tabular}{|c|c|c|c|c|c|}
\hline \multirow[t]{2}{*}{ Authors } & \multicolumn{5}{|c|}{ Walkability Parameter Categories } \\
\hline & Density & Diversity & Design & $\begin{array}{l}\text { Destination/ } \\
\text { access }\end{array}$ & Distance \\
\hline $\begin{array}{l}\text { Walk } \\
\text { Score } \\
(2014)\end{array}$ & $\begin{array}{l}\text { People: } \\
\text { Enough peo- } \\
\text { ple for busi- } \\
\text { nesses to } \\
\text { flourish and } \\
\text { for public } \\
\text { transit to run } \\
\text { frequently. }\end{array}$ & $\begin{array}{l}\text { Mixed income, } \\
\text { mixed use: Af- } \\
\text { fordable hous- } \\
\text { ing located near } \\
\text { businesses. }\end{array}$ & $\begin{array}{l}\text { A center: } \\
\text { Walkable } \\
\text { neighborhoods } \\
\text { have a center, } \\
\text { whether it's a } \\
\text { main street or } \\
\text { a public space. } \\
\\
\text { A pleasant } \\
\text { environment } \\
\text { to walk with } \\
\text { attractive fea- } \\
\text { tures } \\
\text { Pedestrian } \\
\text { design: Build- } \\
\text { ings are close } \\
\text { to the street, } \\
\text { parking lots } \\
\text { are relegated } \\
\text { to the back. } \\
\text { Complete } \\
\text { streets: De- } \\
\text { signed for } \\
\text { bicyclists, pe- } \\
\text { destrians, and } \\
\text { transit. }\end{array}$ & $\begin{array}{l}\text { Parks \& pub- } \\
\text { lic spaces: } \\
\text { Plenty of } \\
\text { public places } \\
\text { to gather and } \\
\text { play. }\end{array}$ & $\begin{array}{l}\text { Schools \& } \\
\text { workplaces: } \\
\text { Close enough } \\
\text { that most } \\
\text { residents can } \\
\text { walk from their } \\
\text { homes. }\end{array}$ \\
\hline
\end{tabular}




\begin{tabular}{|c|c|c|c|c|c|}
\hline \multirow[t]{2}{*}{ Authors } & \multicolumn{5}{|c|}{ Walkability Parameter Categories } \\
\hline & Density & Diversity & Design & $\begin{array}{l}\text { Destination/ } \\
\text { access }\end{array}$ & Distance \\
\hline $\begin{array}{c}\text { Walkable } \\
\text { Commu- } \\
\text { nities } \\
(2014)\end{array}$ & $\begin{array}{l}\text { Number of } \\
\text { people: In } \\
\text { walkable } \\
\text { communities } \\
\text { there are } \\
\text { many people } \\
\text { walking. } \\
\text { Residential } \\
\text { densities. }\end{array}$ & $\begin{array}{l}\text { A hearty, } \\
\text { healthy set of } \\
\text { stores. } \\
\text { Mixed income, } \\
\text { mixed use } \\
\text { near the town } \\
\text { center and, in } \\
\text { a large town, } \\
\text { at appropriate } \\
\text { transit locations. }\end{array}$ & $\begin{array}{l}\text { The town is } \\
\text { thinking small, } \\
\text { not permitting } \\
\text { to build stores } \\
\text { above a rea- } \\
\text { sonable sf. } \\
\text { Well-linked } \\
\text { streets \& trails. } \\
\text { Key streets are } \\
\text { speed con- } \\
\text { trolled. } \\
\text { Amenities: to } \\
\text { make walking } \\
\text { feasible and } \\
\text { enjoyable for } \\
\text { everyone. } \\
\text { Universal de- } \\
\text { sign. The com- } \\
\text { munity has a } \\
\text { healthy respect } \\
\text { for people of } \\
\text { all abilities, } \\
\text { Intact town } \\
\text { centers: This } \\
\text { center includes } \\
\text { a quiet, pleas- } \\
\text { ant main street. }\end{array}$ & $\begin{array}{l}\text { Public space: } \\
\text { There are } \\
\text { many places } \\
\text { for people } \\
\text { to assemble, } \\
\text { play, and as- } \\
\text { sociate with } \\
\text { others within } \\
\text { their neighbor- } \\
\text { hood. }\end{array}$ & $\begin{array}{l}\text { Design is prop- } \\
\text { erly scaled to } \\
1 / 8,1 / 4 \text {, and } \\
1 / 2 \text { mile radi- } \\
\text { us segments. }\end{array}$ \\
\hline
\end{tabular}


According to Duany (Duany \& Plater-Zyberk, 1995), a balanced human activity in neighborhoods contains:

- A variety of housing amenities.

- Adequate shopping.

- A range of workplaces.

- The facilities for elementary education.

The complete neighborhood concept is similar to Andres Duany's neighborhoods of balanced human activity concept. The proposed City of Portland Comprehensive Plan (City of Portland, 2014a) identifies goods and services needed in the daily life of a complete neighborhood as:

- Variety of housing options.

- Grocery stores.

- Other commercial services.

- High quality public schools.

- High quality parks.

In addition, complete neighborhoods are anchored with a center of:

- Retail stores and businesses (grocery stores, restaurants, markets, shops, etc.).

- Civic amenities (libraries, schools, community centers, places of worship, etc.).

- Housing options.

- Health clinics. 
- Daycare centers.

- Employment centers.

- Plazas and parks.

- Other public gathering places.

Andres Duany says that these amenities "are integrated to other neighborhoods by a network of small streets. Neighborhoods aggregate to form towns and cities while a single neighborhood, standing free in the landscape, is a village" (Duany \& Plater-Zyberk, 1995).

Lavey (2014) mentions key destinations as

- Workplaces.

- Corner stores/markets.

- Schools.

- Restaurants.

- Retail.

- Public spaces and parks.

- Transit stops.

- Culture such as museums and music venues. 


\begin{tabular}{|c|c|c|}
\hline \multicolumn{3}{|c|}{ Farmers Branch Station Area Plan, Dallas } \\
\hline \# & & Coding Standards \\
\hline 1 & New Development-block & Lots front streets \\
\hline 2 & & $\begin{array}{r}\text { No Block larger than } 400 \text { ' without alley, common drive, } \\
\text { access easement, or pedestran pathway }\end{array}$ \\
\hline 3 & & Alleys access to rear of all lots \\
\hline 4 & & Exception in lots with less than $75^{\prime}$ frontage \\
\hline 5 & & Curb cuts one per 200' of street. \\
\hline 6 & & Other Alley standards \\
\hline 7 & Building & $\max 60,000$ sf per floor \\
\hline & & average street frontage length less that $60^{\prime}$ or $70^{\prime}$ \\
\hline 8 & & depending on the shopfront \\
\hline 9 & & all facades shall have a street entry \\
\hline & & If frontage less than 100 ' there is an exemption from \\
\hline 10 & & the above building standards \\
\hline 11 & & Standards on where different frontages meet \\
\hline 12 & Streetscape & street trees at less than $30^{\prime}$ on center \\
\hline 13 & & Never exceed $45^{\prime}$ on center \\
\hline 14 & & street lights at less than $75^{\prime}$ off center paralle to street \\
\hline 15 & & requirement for sidewalk installation \\
\hline 16 & Parking & Under 20.000' no minimum requirements \\
\hline 17 & & Shared parking standards \\
\hline 18 & & Parking standards for sites $>20,000^{\prime}$ \\
\hline 19 & & No max limits on shared parking for residential units \\
\hline 20 & & $1 / 1000$ sf of shared parking in non-residential \\
\hline 21 & Building Standards & allowed-prohibited uses \\
\hline 22 & Streetscape Standards & $\begin{array}{r}\text { Street trees on every street, } 3^{\prime} \text { from the curb at no } \\
\text { greater than } 30^{\prime} \text { on center }\end{array}$ \\
\hline 23 & & Trees at least 3 " at time of planting and 10 ' in height \\
\hline 24 & & Tree species from specified list \\
\hline 25 & & $\begin{array}{r}\text { Maintain trees to not interfere with pedestrian } \\
\text { sidewalk movement or truck travel, } 7 \text { ' over sidewalk } \\
\text { and } 14^{\prime} \text { over street. }\end{array}$ \\
\hline 26 & & Rear yard landscaping standards \\
\hline 27 & & Sidewalks at least 6' wide and per city specs \\
\hline & & Maintenance standards and other landscape \\
\hline 28 & & standards \\
\hline 29 & & Allow proper drainage on parking sites \\
\hline 30 & & Same tree alignment reqs for greens and squares \\
\hline 31 & & $20-30 \%$ unpaved surface only in squares \\
\hline 32 & Architectural Standards & Permitted materials visible from the street \\
\hline & & Horizontal wall dimension of wall opening shall not \\
\hline 33 & & exceed vertical \\
\hline 34 & & Wall openings not more than a story high \\
\hline
\end{tabular}


Wall openings to correspond with building interior

Wall openings shall not span acrooss building structure

Matrial texture and arrnagement standards Matrials permitted for roofs and parapets Materials permitted for street and garden walls Vehicle entry gates $18^{\prime} \max$ Pedestrian entry gate, 6' $\max$ other material configuration standards for walls

Matrials permitted for windows and doors configurations permitted for windows and doors Configuration and material standards for shopfront windows and doors

$60 \%$ minimum of the window pane area shall allow views to the ground floor at a depth of at least $15^{\prime}$ prohibition of opaque windows doors spanning more than one story not allowed doors recessed more than 3 ' are not allowed Horizontal dimension of openings shall not exceed vertical one

windows no closer than 30 " to corners of buildings

Materials and configuration of signs and sign placement Materials and configuration of awnings and awning

placement

Lighting and mechanical equipment

Signage Materials and configuration of street lighting Placing of mechanical equipment

\begin{tabular}{|c|c|c|}
\hline \multicolumn{3}{|c|}{ Benicia, CA } \\
\hline \# & & Coding Standards \\
\hline 1 & Setbacks, & Building Built-to Line-Front \\
\hline 2 & & Building Built-to Line-Side Street \\
\hline 3 & & Building Setback Side \\
\hline 4 & & Building Setback Rear \\
\hline 5 & & Building Primary Street Façade built to BTL \\
\hline 6 & & Building Side Street Façade built to BTL \\
\hline 7 & & Building Corner Street Façade built to BTL \\
\hline 8 & Lot & Lot Width \\
\hline 9 & & Lot Depth \\
\hline 10 & Entry & Primary Ground Floor Entry Location \\
\hline 11 & & Loading dock location \\
\hline 12 & & Overhead door and service entry location \\
\hline \multicolumn{3}{|c|}{ St Lucie County, FL } \\
\hline \# & & Coding Standards \\
\hline 1 & Lot size and dim req per building type lot & Lot size(min/max) \\
\hline 2 & & Lot width $(\min / \max )$ \\
\hline 3 & & Building Frontage (min/max) \\
\hline
\end{tabular}


Lot coverage by bldgs (max)

Front Yard (min/max)

rear yard (min)

Side yard ( $\mathrm{min}$ )

Height ( $\mathrm{min} / \mathrm{max}$ in stories, max in feet)

First story elevation (min)

Accessory dwelling (max bldg footprint in sf)

Streetscape Standards

Street edge type

corner radius

planting strip type

planting strip width

planting strip tre spacing

planting strip tree diversity

Walkway type

walkway width

Rear alley/lane req

Street network design

bicycle and pedestrian travel design req centerline offsets or jogs at least 100'

transit service req

public ownership of streets req

traffic calming element encouragment

cul de sacs are not permitted

stub-out streets requirement for future dev

connections

Full-access intersections min separation in feet

28

29

30

31

32

33

34

35

36

37

38

39

40

41

Requirement for network of trails and greenways

Street design

Parking

Civic building/space standards

Open space/countryside standards
Sidewalk width planter width street parking width inner lane width outer lane width median width street surface width ( $\min / \mathrm{max}$ )

Tree presence

Alley/Lane widths trail width (min-max) off-street regulations

various Various

\begin{tabular}{|c|c|c|}
\hline \multicolumn{3}{|c|}{ Lee County, FL } \\
\hline \# & & Coding Standards \\
\hline 1 & Transect Zones & $5 \%$ civic spacesin addition to planting strips \\
\hline 2 & Streets & Streets per transect must follow street sections \\
\hline 3 & & Streets must be assigned per transect as per table \\
\hline 4 & & Street types must be shown in regualting plan \\
\hline 5 & & must provide interconnected network \\
\hline 6 & & must accommodate existing or anticipated transit \\
\hline 7 & & Streets by movement types \\
\hline 8 & & Streets and alleys publicly dedicated \\
\hline
\end{tabular}


no entrance gates or gated streets in compact

Street stubs for connectivity to adjacent future

12

13

14

15

16

17

18

19

20

21 developments

Streets acording to County construction standards

Speed per street type

streets must connect to other streets

centerline offsets at intersections with arterials

sight distances per Florida standards

in General and Edge transects streets other than B or F

must be justified dead-end streets prohibited

provide sidewalks and rows of street trees on both sides of streets only alleys and lanes in interior of blcoks

a continuous network of lanes and alleys for individual lots in Core, Center and General Transect zones rear lanes in Edge Transect for lots $<60$ ' width

bends in alleys must allow collection trucks to turn if no alley, lot fronts must have 10 ' utility easement to accommodate 'wet' utilities block perimeter $<2000$ ' only under certain condition but 1600 max recommended Block faces $>500$ ' must include a publicly dedicated sidewalk, passage or trail at least 8 ' in width connecting to another street cross sections per figures provided sidewalk width street parking width access lane width planting strip width travel lane widths planting median width yield condition on the street alley ROW width rear-lane width boulevard avenue Street A street B street $C$ (angled parking) street $D$ (one way) street $E$ (access street0

Street $F$ Drive road rear alley rear lane Streetscape Standards raised curb corner radius street tree planter type 200 
off-street parking within or in the rear of buildings to screen parking areas from paths and sidewalks

other than parking garage parking must have primary access from rear alleys or lanes maintain access to all properties along alleys cross access requirements to adjoining rear lots only on Pedestal Building type

liner requirements to all buildings parking vehicles parking structures up to 5 levels of parking above grade 65 66 67 68 69 70
Lot types specific type sof lots per trasect specified

15 types of various lot types: pedestal building lined building mixed-use building apartment building courtyard building live-work building rowhouse lot aprtment house duplex cottage house sideyard house house civic building civic space stormwater Placement of buildings on lots examples upper story allowable setback max block width max lot width street yard presence sidewalk presence plantng strip presence parkin glane presence alley lane presence porch presence

primary entrance must face street or public space

frontage percentage max allowed front setback and \% of building allowed to setback $\%$ of primary façade as a fourcourt depth of forecourt lot area $\mathrm{min} / \mathrm{max}$ Lot width (min/max) 201 
100

101

102

103

104

105

106

107

108

109

110

111

112

113

114

115

116

117

118

119

120

121

122

123

124

125

126

127

128

129

130

131

132

133

134

135

136

137

138

139

140

141

142

143

144 frontage percentage

Lot coverage by bldgs (max) street setbacks per transect

Side yard ( $\mathrm{min})$

rear yard (min)

water body ( $\mathrm{min}$ )

building height ( $\mathrm{min} / \mathrm{max}$ in stories; max in feet) per

trasect

accessory apertments allowance (and building footprint in sf)

front porch setback from public ROW

awning requirement

awning depth on ground floors

awning clearance on ground floors

awning extent on ground floors

prohibited awning materials

second story balcony depth

second story balcony clearnace from sidewalk second story balcony primary façade extent

colonnades and arcades distance to building

colonnades and arcades clearance above sidewalk

colonnades and arcades primary façade extent

maintenance responsibility of above features

windows primary façade extent

storefronts unshuttered at night

shorefronts lit from within till 10pm

building street door interval max (75')

liner buildings at least two stories

liner building depth (20' $\mathrm{min})$

liner buildings to comply with transparency requirements

building width alon g street facades (max)

buindings occupying more than one lot must vary their

façade to reflect such differences ground story height (max-min) other stories min-max height stories higher than 12 ' count as two stoey height measurement standards ground floor elevation if flooding possibilities

protection of ground floor merchandise from flooding

residential ground floor elevation min above sidewalk (if more than 5 ' then it counts as a story)

\# of accessory apartments allowance accessory aprts sidewayrd req.

network of alleys and lanes as primary entry to lots detached garages in rear of lots

detached garages location in relation to residence

driveway width $\max \left(10^{\prime}\right)$

Permitted uses Civic buildings permitted uses per relevant table per lot type no mandatory setbacks or frontages 202 
$\min .0 .5$ acres to civic building lots in communities of

certificate of occupancy within 3 yrs of first building

active civic spaces:

neighborhood park playground community garden

passive civic spaces:

Civic space design and landscaping consistent to civic

building primary façade max facing plazas and squares depict immediately adjoining roads and other rights of must show wingle transect designations to all subdivided into lots must show all streets and indicate type of street must show lot lines and lot types for all land subdivided into lots

follow sample regulating plan for amount of detail required submittal requirements utlility depiction requirements Tranfer of Development Rights stormwater management requirements Rezoning elimination Transfer of develoment right requirements Cincinnati, $\mathrm{OH}$

\#
Coding Standards

Specific to Transect Zones

Building types allowed Building types lot width (min/max) Building types lot depth 


\begin{tabular}{|c|c|}
\hline 4 & Building height stories max \\
\hline 5 & Building height to Eve/Parapet \\
\hline 6 & Building height overal \\
\hline 7 & accessory dwelling stories max \\
\hline 8 & accessory structures other stories max \\
\hline 9 & Ground floor finish level above sidewalk \\
\hline 10 & upper floor min. ceiling height \\
\hline 11 & building footprint lot coverage \\
\hline 12 & accessory structures footprint width max \\
\hline 13 & accessory structures footprint depth max \\
\hline 14 & setback fron \\
\hline 15 & setback side street \\
\hline 16 & setback side main building \\
\hline 17 & setback side accessory structures \\
\hline 18 & setback rear min, main building for lot depths $<=100$ \\
\hline 19 & setback rear min, main building for lot depths $>100$ \\
\hline 20 & setback accessory structure min \\
\hline 21 & façade within front façade zone $\% \mathrm{~min}$ \\
\hline 22 & façade within side façade zone $\%$ min \\
\hline 23 & parking in residential uses per dwelling unit \\
\hline 24 & parking in service uses per sf of building \\
\hline 25 & parking additional table for non transect listed uses \\
\hline 26 & parking front setback \\
\hline 27 & parking side stret setback \\
\hline 28 & parking side setback \\
\hline 29 & parking rear setback \\
\hline 30 & parking curb cut width max at street \\
\hline 31 & driveway width alley \\
\hline 32 & encroachment frontage max, front street, side street \\
\hline 33 & encroachment steps to building max, front, side str \\
\hline 34 & $\begin{array}{r}\text { Encroachment architectural features max, front, side } \\
\text { street, side, rea }\end{array}$ \\
\hline 35 & $\begin{array}{r}\text { Encroachment signage allowed/not allowed, front, side } \\
\text { street, side, rear }\end{array}$ \\
\hline 36 & $\begin{array}{r}\text { encroachment landscaping allowed/not allowed, front } \\
\text { side street, side, rear }\end{array}$ \\
\hline 37 & $\begin{array}{l}\text { Encroachment, fences or freestanding wall, } \\
\text { allowed/not allowed, front, side street, side, rear }\end{array}$ \\
\hline 38 & $\begin{array}{r}\text { encroachment driveways, walkways allowed/not } \\
\text { allowed front, side street, side, rear }\end{array}$ \\
\hline 39 & $\begin{array}{l}\text { encroachment utility lines, wires, related structures } \\
\text { allowed/not allowed front, side street, side, rear }\end{array}$ \\
\hline 40 & $\begin{array}{r}\text { encroachment, sitellite Dish Antennas allowed/not } \\
\text { allowed front, side street, side, rear }\end{array}$ \\
\hline 41 & encroachment allowance within the street ROW \\
\hline 42 & building signs max per building \\
\hline
\end{tabular}


43

44

45

46

47

48

49

50

51

52

53

54

55

56

57

58

59

60

61

62

63

64

65

66

67

68

69

70

71

72

73

74

75

76

77

78

79

80

81

82 ground signs max per building building sign types allowed ground sign types allowed residential use types allowed/not allowed by permit, minor use permit, use permit dwelling accessory dwelling home occumation home office

Service uses allowed day care home

lodging, bed and breakfast recreation, education, public assembly uses allowed/not allowed by permit, minor use permit, use permit cemetery cultural institution

park/open space/playground public safety facility recretional facility outdoor religious assembly public or private school studio, art, music, dance community garden allowed/not allowed by permit, minor use permit, use permi Transportation. Communications, infrastructure utilties allowed/not allowed by permit, minor use permit, use accessory building structure allowed/not allowed by permit, minor use permit, use permi Speciifc to Building Types building type allowance per transect zone accessory buildings allowed

secondary wings and accessory structures max width, depth, height and $\mathrm{n}$ relation to the main building

uses per building type allowed number of units per building type building frontage separation max width, depth, separation distance

building type height, footprint in relation to main building

floor footprint in relation to lower floor allowed frontage types

allowed main pedestrian access entrance location, front, side, alley, internal, garage ground floor/upper floor units entrance counts and location corner lot pedestrian entry req. parking access front, side, alley private open space min or min per unit width, depth, area in $\mathrm{sf}$ courtyard width/depth/width to height ration min, max, ratio

florr max width, depth, lot coverage residetial florr width, depth, lot coverage 205 
83

84

85

86

87

88

89

90

91

92

93

94

95

96

97

98

99

100

101

102

103

104

105

106

107

108

109

110

111

112

113

114

115

116

117

118

119

120

121

122

123

124

125

126

127

128

129

130 commercial floorplate max sf

residential floorplate max sf

floorplate $\%$ of lot

Mid-Rise and High-Rise Type Standards

Specific to Frontage Types

setback per floor level, front, side, rear

frontage type descriptions frontage type depth

fence allowance

clear width, depth, height, finish level above sidewalk, furniture area path of travel

frontage type sides

distance between glazing

ground floor transparency

depth of recessed entries

height, depth of landing above the sidewalk height, depth of lightwell below sidewalk setback from curb

depth of recessed entries

presence of residential windows

recessed doors allowance

distance between stairs in terrace frontage

Supplemental to Transect Zones

pecific to Creating a Walkable Neighborhoo

Topography and Hillside Overlay District Standards

parking standards additional parking adjustments

bicycle parking req per use

renovations and new construction compatibility

standards

sign standards

corner store standards specific uses standards

structure with pedestrian sheds allocate transect zones

layout block and thoroughfare network according to

standards

allocate open space according to standards provide neighborhood centers/main streets provide mix of building types provide transitions to scale and character of surrounding area calibrate to the local tographical etc features

Pedestrian Sheds

have a center

pedestian shed standards

center

type

size in acres

remnant areas outside a pedestrian shed

regulating plan inclusion

Transect Zone Mix

allocation

organization

transition

$\%$ of neighborhood land per each transect allowed, min.

$\max$ per relevant standards 
adjust the character when going from one transect to the next accordingly alignment and
provide stubs for adjoining development minimum block length

no dead end streets and cul-de-sacs on the regulating plans

temporary dead-end streets allowance cul-de-sac approval conditions cul-de-sac min radius and ROW cul-de-sac median requirement cul-de-sac pedestrian easement requirement

143

144

146

147

148

149

150

151

152

153

154

155

156

157

158

159

160

161

162

163

164

165

166

167

168

169 per provided table

block size per transect max face length and max

perimeter length

designated on a regulated plan

Open Space, Civic Space and Civic Buildings

public access and visibility requirement along natural

open spaces

public access requirement along natural open spaces

through the use of:

single loaded open streets

bike and pedestrian paths

other frontage methods providing access and visibility

per set stabdards

$10 \%$ of any project $>4$ ac area as civic or open space not including rows or $>8 \mathrm{ac}$ if withinin 1000' of existing playgound.

Open space distribution requirements

$>4$ ac sites for civic buildings

civic size requirement if in proximity to another civic space

location of school requirements within the pedestrian shed (in center).

civic and open space types

civic space service area per civic space type and

transect

civic space size per civic space type and transect min-

$\max$

civic space facilities per civic space type and transect

$\min -\max$

civic space frontage per civic space type and transect

civic space disposition (formal/informal) of elements

per civic space type and transect location near the center of pedestrian shed main streets along both sides of thoroughfare

in relation to the thoroughfare, along a primarythoroughfare or perpendicular to it

elements to contain

civic buildings

civic uses

civic or open spaces

limited retail or service uses 207 
170

172

173

174

175

176

177

178

179

180

181

182

183

184

185

186

187

188

189

190

191

192

193

194

195

196

197

198

199

200

201

202

203

204

205

206

207

208 min lot depth

min linear feet of frontage

min \# of lots to be built during the first phase of the

project

Building Type Mix

per standards

diversity of uses and \# of building types requirement

per transect

use mix and building types when more than one

trasect per block

transportation and public frotage assemblies

per transect and per tables

parking lane max width for angled or parallel parking

parking tick mark location alley lane presence requirement alley paving requirement

alley public frontage ot transportation requirements rear lane public frontage ot transportation requirements public frontage elements public frontage element transition from transect to transect

min width specification for walkways or planters requirement for a verge, utility and public infrastructure and furniture outside pedestrian access

way

requirement for public planting and lighting location of lighting requirement in the verge public planting according to standards tree regular spacing waiver to avoid shopfront obstruction

palnting requirements in front of arcades and galleries

utility easements per standards and relevant table

wet utility location requirement overhead utility requirements

overhead utility requirements in alleys and rear lanes pedestrian access easement requirements landscape planting species requirements tree minimum height and initial caliper tree warranty requiments

landscapin grequirement excemptions in parking lots trees per parking spaces in peakring lots bicylce accommodation in throroughfares per design speed other bicycle lane suggestions Cincinnati bicycle plan standards requirement segment requirement per thoroughare type thoroughare type requirement per transect intersection curb radii and tyoe per thoroughfare type 208 

median width median planting median surface target speed bicycle provision transit provision type of frontage curb type pedestrian widths vehicular area width apporved tree species approved tree arrangement, spacing and mix street lighting types, height min-max

\begin{tabular}{|c|c|c|}
\hline \multicolumn{3}{|c|}{ Peoria, IL } \\
\hline \# & & Coding Standards \\
\hline 1 & To all Districts & city annexed land req. \\
\hline 2 & & \# of buildings per lot req \\
\hline 3 & & lot division req \\
\hline 4 & & min lot size req. \\
\hline 5 & & lot size req \\
\hline 6 & & yard req \\
\hline 7 & & setback req \\
\hline 8 & & required yard obstruction req \\
\hline 9 & & setback regs \\
\hline 10 & & permitted obstructions in required yards \\
\hline 11 & & 3' max above ground terrace \\
\hline 12 & & awnings and canopies \\
\hline 13 & & steps 4 ' or less above grade \\
\hline 14 & & chimneys 2 ' max projection into the yard \\
\hline 15 & & approved free standing signs \\
\hline 16 & & arbors and trellises \\
\hline 17 & & etc. \\
\hline 18 & For Residential Districts & \\
\hline 19 & building envelope standards & lot density (max units/gross acres \\
\hline 20 & & lot min sf \\
\hline 21 & $\begin{array}{l}\text { Il standards are recorded since these } \\
\text { ot described as pedestrian oriented } \\
\text { districts }\end{array}$ & min area in sf per unit \\
\hline 22 & & lot min width \\
\hline 23 & & corner lot min width \\
\hline 24 & & $\begin{array}{r}\text { yard principal structure min ft front, side, interior, side, } \\
\text { corner, rear }\end{array}$ \\
\hline 25 & & $\begin{array}{r}\text { yard accessory structure mon ft front, side, interior, } \\
\text { side corner rear }\end{array}$ \\
\hline 26 & & principle structure max height in $\mathrm{ft}$ \\
\hline 27 & & accessory structure max height in $\mathrm{ft}$ \\
\hline
\end{tabular}


transitional buffer interior side yard \% of lot width transitional buffer rear yard \% of lot depth 5 ' max setback from existing setbacks req building height common standards porches front entries to the street garages large garages away from the street lighting

house design compatibility with existing houses

Commercial Districts

envelope standards

1

$$
\text { Design Standards for residential districts }
$$

10

max setback line 80 ' behind ROW for general frontage,

parking setback line, 15 ' behind any ROW line and 5' behind a non-ROW lot line. Not affecting stret parking

principle structure max height in stories. Attic stories not counted floor height from top of finished floor below to top of finished floor above min-max ground floor elev from exterior sidewalk to top of finished ground floor

parking structures within $40^{\prime}$ of principle building shall not exceed eve or parapet height of building

first floor interior clear height and max story height

max floor to floor story height other than ground upper story max clear interior height. mezzanines counted as full stories depending on $\%$ of floor area they occupy max that side of building height if within 40' of residential area building facades up to $\mathrm{X} \%$ of required building line on primary and side streets

building façade to building line within $\mathrm{X} f \mathrm{ft}$ from corner

builfding façade jogs of no more than 18in unless otherwise for doors, windows balconies or shopfronts max ground floor area in $\mathrm{ft}$ buildings occupy any portion of lot behind building line excl req setbacks setback req if abutting residential district garage entries and driveways distance from block corners 210 
60

61

2

63

64

65

66

67

68

69

70

71

72

73

74

75

76

77

78

79

80

81

82

83

84

85

86

87

88

89

90

91

92

93

94

95

96

97

98

99

100

101

102

103

104

garage entry clear height max garage entry clear width max

below grade parking excempt from parking setback req

no req setback from alleys min setback for lots with no alley access privacy fences location along lot line lot line treatment if abutting residential lot, wall or bufferyard ped frontage (only additional mentioned)

blank wall lengths more than 20' prohibited windows and doors \% of façade area min-max balcony and stoop proximity to common lot line

beyond the building line allowed encroachments awning max projection, min clear height and max proximity to curb when no trees. awning support requirements entry door interval additional building envelope requirements

industrial districts permitted land uses per district ict requirements (non ped) uses table standards per type of use, residential, civic, commercial, industrial, institutional, parking accessory standard uses temporary uses use categories

Form District Standards

general provisions buildings aligned and close to street agreement of buildings facing across the street

property lines are physically defined by buildings active fronts in buildings

building views oriented to the street not to the lots regulating plan inclusions existing lot, building, parking setback, lot line, type of frontage, buiding line, civic or not al lots share street front, al lots part of a block block max length without alley or other pathway

lot size min to meet pathway req within the block curb cut intervals alley access options and per relevant standards max building floor plate

façade composition \% of the street frontage entry required on street frontage

requirements when façade standards change same set of standards as in commercial districts 211 
architectural standards

105

106

107

108

109

110

111

112

113

114

115 sidewalk, parking, lane widths tree lane, pedestrian crossing dimensions intersection crsossing distance tre planter size

sidewalk dooryard space, clear walking space, tree space mid-block crossing req per block length mid-block crossing streetspace req mid-block crossing max crossing distance max parallel parking width paved street-space width central median width 